\title{
JUNY KRAICZYK
}

A BIOÉTICA E A PREVENÇÃo DA AIDS PARA TRAVESTIS

BRASÍLIA

2014 


\section{UNIVERSIDADE DE BRASÍLIA \\ FACULDADE DE CIÊNCIAS DA SAÚDE \\ PROGRAMA DE PÓS-GRADUAÇÃO EM BIOÉTICA \\ CÁTEDRA UNESCO DE BIOÉTICA}

\section{JUNY KRAICZYK}

A bioética e a prevenção da aids para travestis

Dissertação apresentada como requisito parcial para obtenção do Título de Mestre em Bioética pelo Programa de Pós-Graduação em Bioética da Universidade de Brasília.

Orientador: Prof. Dr. Wanderson Flor do Nascimento

BRASÍLIA

2014 


\section{Juny Kraiczyk}

\section{A bioética e a prevenção da aids para travestis}

Dissertação apresentado como requisito parcial para obtenção do Título de Mestre em Bioética pelo Programa de Pós-Graduação em Bioética pela Cátedra UNESCO de Bioética da Universidade de Brasília - UnB.

\section{Banca Examinadora}

Prof. Dr. Wanderson Flor (presidente) Universidade de Brasilia

Profa. Dra. Flávia do Bonsucesso Teixeira (Membro)

Universidade de Uberlândia

Profa. Dra. Dais Gonçalves Rocha (Membro)

Universidade de Brasília

Prof. Dr. Natan Monsores (Suplente)

Universidade de Brasília 


\section{AGRADECIMENTOS}

Ao Prof. Dr. Wanderson Flor do Nascimento pelas palavras generosas e pela orientação cuidadosa que permitiu seguir em frente sem deixar de apontar as correções necessárias. À equipe da Secretaria do Programa de Pós-Graduação em Bioética (PPG-Bioética), Shirleyde, Dalvina, e Cleide e da Cátedra Unesco de Bioética, pela atenção dispensada, sempre gentil, pronta e efetiva.

Ao Departamento de DST/HIV/Aids pela rica experiência no campo da aids e nos universos "trans", também pelo tempo proporcionado para que eu frequentasse parte das aulas.

Agradeço à CAPES - Programa CAPES - pela bolsa recebida para fazer o mestrado.

À Wilza Villela, Claudio Lorenzo e Rita Segato pelo aprendizado instigante no campo da saúde, da bioética e da vida.

À Cisa pela tradução.

Para os (as) amigos (as) por terem acreditado e também pela embriagues e pelo amor. Dani por dividir a vida e por tornar a minha mais bonita. Edina irmã de alma pra vida toda. Pelo inicio e resto da jornada. À Jeane Felix cujo apoio na organização do trabalho, leitura e escuta cuidadosa. Elaine Bortolanza por me lembrar que a vida é poética, potente, intensa e vale a pena. Lis querida, pelas conversas, trocas, risos, choros, revisões e pelas longas tardes com Florinha enquanto eu escrevia. Também pela champanhe final e pelo amor desde sempre. Narinha minha irmã, pela cumplicidade, gentileza, espiritualidade e amor... muito amor. Katia Magrinha pelo carinho e cuidado conosco. Fabiane Borges por ser quem é e por me transportar pra outras dimensões mesmo de longe. Silvia Cavasin, Sandra Umbehaum e Wilza Villela por me apresentarem um caminho e por serem minhas referências neste caminho; Ivo Brito, Angel Donini e Dulce Ferraz pela amizade, aprendizados e acolhida nesta terra quente; Magali Eleutério pela força, pelas comidinhas, pelo carinho e pela certeza de que a vida se faz de gente forte; Paulinho pelas trocas e conversas infindáveis pela vida a fora; Flavia Teixeira pela leitura sugestões e cafés instigantes;

À minha mãe... por tudo. Pelo amor, pelo apoio incondicional, por ser uma mulher 
incrível e por me fazer ser quem eu sou.

Ao Lucas pelo companheirismo, trocas de diferentes ordens, apoio incondicional. Por me ensinar a ter mais calma, pelos dias mal dormidos, pelo apoio intelectual e braçal na dissertação. Por me proporcionar ser a mãe da Flora. Por me fazer feliz!

De forma muito especial, agradeço a Keila Simpson, Cris Stefani, Fernanda Benvenuti, Jovanna Baby, Marcely Malta, Rafaelly Wiest por terem me feito entender um pouco mais o universo deste trabalho.

Por fim, dedico esta dissertação à pequena Flora Kraiczyk Seara minha filha amada. 
Como se eu estivesse por fora do movimento da vida. A vida rolando por aí feito rodagigante, com todo mundo dentro, e eu aqui parada, pateta, sentada no bar. Sem fazer nada, como se tivesse desaprendido a linguagem dos outros. A linguagem que eles usam para se comunicar quando rodam assim e assim por diante nessa roda-gigante.

Você tem um passe para a roda-gigante, uma senha, um código, sei lá. Você fala qualquer coisa tipo bá, por exemplo, então o cara deixa você entrar, sentar e rodar junto com os outros. Mas eu fico sempre do lado de fora. Aqui parada, sem saber a palavra certa, sem conseguir adivinhar. Olhando de fora, a cara cheia, louca de vontade de estar lá, rodando junto com eles nessa roda idiota - tá me entendendo,

A roda? Não sei se é você que escolhe, não. Olha bem pra mim - tenho cara de quem escolheu alguma coisa na vida? Quando dei por mim, todo mundo já tinha decorado a tal palavrinha-chave e tava a mil, seu lugarzinho seguro, rodando na roda. Menos eu, menos eu. Quem roda na roda fica contente. Quem não roda se fode... 


\section{RESUMO}

O objetivo geral deste trabalho é produzir conhecimento acerca das estratégias de prevenção do HIV/AIDS, voltadas para as travestis, a partir da Bioética de Intervenção e da Declaração Universal dos Direitos Humanos (DUBDH). O alto índice de infecções pelo HIV e dos casos de aids entre as travestis implica no reconhecimento da gravidade da epidemia entre esta população, e, consequentemente, demanda questionamentos das estratégias de prevenção das políticas governamentais, com vista a atenuar os impactos deste fenômeno. Para tanto, este trabalho discorre sobre o fato de que as pessoas vivenciam seus corpos, gênero e suas sexualidades de diferentes maneiras, obrigando um novo olhar a tais processos, para definir o que é ou não é "natural" e agregar as “descontinuidades" e/ou "incoerências sexuais", inclusive junto as políticas públicas. Nestes termos, o trabalho evidencia ainda que as violações dos direitos resultam na expectativa de morte e no risco de adoecimento em decorrência da aids e compõem as experiências subjetivas, fazendo dialogar os nexos de causalidade entre as dinâmicas sociais e o elevado risco para o HIV entre pessoas trans. A partir do histórico das políticas nacionais relacionadas às travestis, de experiências dos encontros e de programas de prevenção, afirma-se a necessidade de que as especificidades das travestis sejam consideradas na elaboração, planejamento e consecução das políticas de prevenção do HIV/AIDS em saúde, de modo que os princípios de equidade, justiça social, o respeito a dignidade da pessoa humana, sejam respeitadas.

PALAVRAS-CHAVE: Bioética, travesti, aids, prevenção, saúde 


\begin{abstract}
The objective of this work is to raise awareness about HIV/AIDS prevention strategies, targeting the transvestite community from the Bioethics Intervention and the Universal Declaration of Human Rights (DUBDH). The high rate of HIV infections and AIDS cases within the transgender community, is evidence of the seriousness of the epidemic among this population, and therefore demands prevention strategies of government policies to mitigate the impacts of this phenomenon. This paper discusses the fact that people experience their bodies, sexuality and gender in different ways, challenging the perception and definition of what is "natural" and reflecting their human rights in public policies. Additionally, the work shows that violations of rights result in the expectation of death and the risk of falling ill due to AIDS and compose the subjective experiences, using arguments of the causal links between social dynamics and the high risk for HIV among transgender people. From the history of national policies related to the transgender individual and from experiences and encounters of prevention programs, it is stated the necessity that the specifics of transgender individuals are considered in the design, planning and implementation of HIV-aids prevention policies on health so that the principles of equity, social justice, and respect for human dignity are respected.
\end{abstract}

KEYWORDS: Bioethics, transvestite, AIDS prevention, health. 


\section{LISTA DE FIGURAS}

Figura 01: cartaz referente a primeira campanha: "Travesti e Respeito"

Figura 02: cartazes referentes à campanha: "Sou travesti. Tenho direito de ser quem eu sou"

Figura 03: Gráfico das vítimas de violência classificadas por identidade em 2012....... 73

Figura 04: Gráfico dos locais de violações em 2012

Figura 05: Gráfico da identidade das vítimas de violações no ano de 2012, segundo o Relatório sobre violência homofóbica no Brasil 75

Figura 06: Gráfico dos locais de ocorrência no ano de 2012, segundo o Relatório sobre violência homofóbica no Brasil 76

Figura 07: Cartazes referentes à divulgação do Disque 100 98

Figura 08: Cartaz referente ao direito ao tratamento pelo nome social 9 


\section{LISTA DE ABREVIATURAS E SIGLAS}

DUBDH - Declaração Universal dos Direitos Humanos

HIV - Vírus da imunodeficiência humana

AIDS - Síndrome da imunodeficiência adquirida

OSC - Organização da Sociedade Civil

SUS - Sistema Único de Saúde

ANTRA - Articulação Nacional de Travestis e Transexuais

OPAS - Organização Pan Americana de Saúde

OMS - Organizac $\square$ ão Mundial da Saúde

CID - Classificação Internacional de Doenças

DSM - Manual Diagnóstico e Estatístico de Transtornos Mentais

BDTD Biblioteca Digital Brasileiras de Teses e Dissertações

ScieLo - Scientific Eletronic Library Online

ENTLAIDS - Encontro Nacional de Travestis e Transexuais na Luta contra a Aids

CNT - Coletivo Nacional de Transexuais

CIOMS/WHO - Internacional Ethical Guidelines for Biomedical Research Involving Human Subjects

UNESCO - Organização das Nações Unidades para a Educação, a Ciência e a Cultura PeP - Profilaxia pós exposição

ARV - Antirretrovirais

PreP - Profilaxia Pré Exposição

ABGLT - Associação Brasileira de Gays, Lésbicas, Travestis e Transexuais

ONG - Organizações não-governamentais 
EXPOGEP - Gestão Estratégica e Participativa no SUS

SDH - Secretaria de Direitos Humanos da Presidência da República

OG - organizações governamentais

OSC - organizações da sociedade civil

UD - usuários de drogas ilícitas

PCAP- Pesquisa de Conhecimentos, Atitudes e Práticas

USAID - United States Agency for International Development

OPAS - Organização Pan-Americana de Saúde

ATTTA- Asociación de Travestis, Transexuales y Transgéneros de Argentina

FBAS - Fundación Buenos Aires Sida

GLTB - Gays. Lésbicas, Transgêneros e Bissexuais

CIT - Comissão Intergestores Tripartite

LGBT - Lésbicas, Gays, Travestis, Transexuais e Bissexuais

DDAH - Departamento de DST/Aids e Hepatites Virais

MS - Ministério da Saúde

SIMOP - Sistema de Monitoramento de Projetos

FCMSCSP - Faculdade de Ciências Médicas da Santa Casa de São Paulo

HSH - Homens que fazem sexo com homens

CONASS - Conselho Nacional dos Secretários da Saúde

CONASEMS - Conselho Nacional das Secretarias Municipais de Saúde

CE - Coordenações Estaduais

PVHA - pessoas que vivem com HIV e ai 


\section{SUMÁRIO}

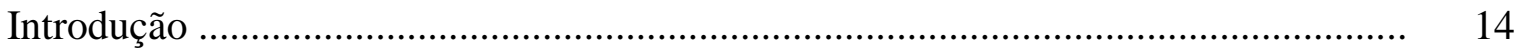

1. A norma posta em cheque .......................................................................... 24

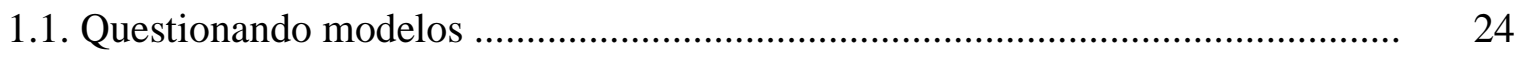

1.2 Travestis: (in)definição de categorias ........................................................... 33

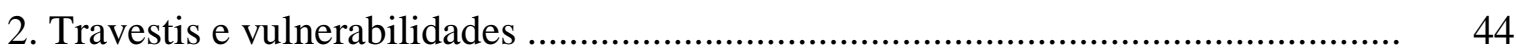

2.1. Vulnerabilidades: um olhar a partir da DUBDH ............................................ 44

2.2. Vulnerabilidade: um olhar a partir dos estudos sobre a AIDS .......................... 53

2.3. As vulnerabilidade vistas de perto ........................................................... 59

3. Facetas da violência e a relação com a infecção pelo HIV/AIDS ........................... 73

4. Para além de dados epidemiológicos ..................................................................... 82

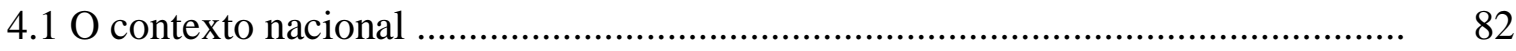

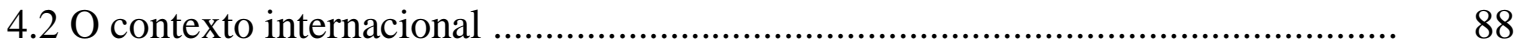

5. Respostas governamentais às demandas de saúde das travestis ............................. 95

5.1. Breve histórico das políticas nacionais de saúde relacionadas às travestis .......... $\quad 95$

5.2. ENTLAIDS e outras respostas para as travestis no campo da prevenção do HIV/AIDS

5.3. Planos Nacional e Estaduais de Enfrentamento às DST, HIV, Aids entre gays, homens que fazem sexo com homens (HSH) e travestis ........................................ 108

4. Considerações a partir da Declaração Universal de Bioética e Direitos Humanos.. 120

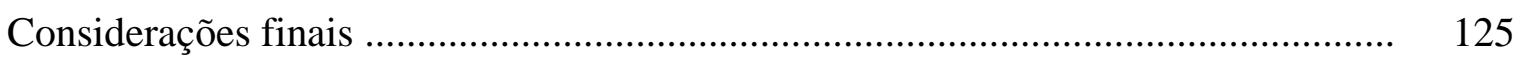

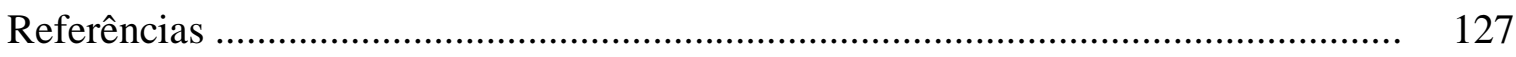

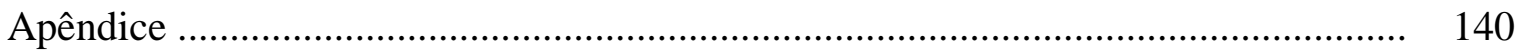




\section{INTRODUÇÃO}

O presente estudo abordará o modelo preventivo do HIV/AIDS ${ }^{1}$ voltado para travestis no Brasil, em contraponto aos contextos de vulnerabilidades, bem como aos aspectos sociais e culturais em que as mesmas estão inseridas, propõe uma reflexão, a partir da "Declaração Universal sobre Bioética e Direitos Humanos" (DUBDH) ${ }^{2}$, sobre temas relacionados à responsabilidade social do Estado, saúde pública, dignidade humana, respeito pelas vulnerabilidades humanas e integridade pessoal, igualdade, justiça e equidade, não-discriminação e não-estigmatização.

O interesse por este tema reflete minha trajetória profissional: entre os anos de 2000 a 2005 atuei como coordenadora do Centro de Educação para a Saúde (CES), uma Organização da Sociedade Civil (OSC) ${ }^{3}$ de Santo André, oportunidade em que me deparei com uma demanda por projetos de prevenção do HIV/AIDS para populações ditas "vulneráveis". Na ocasião, já me questionava sobre como formatar um trabalho junto à comunidade LGBT sem proporcionar o aumento de estigmas e preconceitos.

\footnotetext{
${ }^{1}$ Seguindo Câmara e Lima que se orientam por Castilho, optou-se pela grafia do termo "aids" com letras minúsculas, tendo em vista que se trata de nome de doença, substantivo comum que, a rigor, grafa-se com inicial minúscula (como sífilis, coqueluche, etc.). Entretanto, quando o termo aparecer em siglas conjuntas utilizar-se-á maiúsculas, caso de HIV/AIDS, ONG/AIDS, etc. (182)

${ }^{2}$ A Declaração Universal sobre Bioética e Direitos Humanos (DUBDH) foi aprovada em 2005 pela Organização das Nações Unidades para a Educação, a Ciência e a Cultura (UNESCO). Trata das questões éticas relacionadas à saúde e ciências da vida levando em conta as dimensões sociais, legais e ambientais. Oferece orientação para decisões ou praticas de indivíduos, grupos, comunidades, instituic $\square$ ões e empresas publicas e privadas. Disponível em: http://www.sbbioetica.org.br/wpcontent/uploads/2011/11/TEXTODADUBDH.pdf Acessado em 13 de abril de 2014.

${ }^{3} \mathrm{O}$ termo organização da sociedade civil (OSC) não tem uma definição legal no Brasil, mas é utilizado para representar genericamente aquelas institucionalidades não ligadas ao Poder Público, similar ao conceito de organização não governamental (ONG), que afirma seu não lugar no governo, muito em função do contexto da ditadura. Vale ressaltar que em 2014 entra em vigor a Lei $\mathrm{n}^{\circ} 13.019$, de 31/07/2014, que estabelece o regime jurídico das parcerias voluntárias entre a administração pública e as organizações da sociedade civil, que passam a ser definidas como pessoa jurídica de direito privado sem fins lucrativos que não distribui, entre os seus sócios ou associados, conselheiros, diretores, empregados ou doadores, eventuais resultados, sobras, excedentes operacionais, brutos ou líquidos, dividendos, bonificações, participações ou parcelas do seu patrimônio, auferidos mediante o exercício de suas atividades, e que os aplica integralmente na consecução do respectivo objeto social, de forma imediata ou por meio da constituição de fundo patrimonial ou fundo de reserva (art. $2^{\circ}$, I). Disponível em: http://www.planalto.gov.br/ccivil_03/_Ato2011-2014/2014/Lei/L13019.htm Acessado em 19/10/2014.
} 
Depois assumi um novo trabalho, agora numa ONG de São Paulo/SP, a "ECOS Comunicação em Sexualidade"; situada na rua Major Sertório, um dos locais de maior circulação de travestis que exercem a atividade de prostituição na capital paulistana, este locus me oportunizou atuar junto a jovens, comunidade LGBT, profissionais de saúde e professores da rede de ensino público, dentre as minhas atribuições, destaca-se o desenvolvimento de pesquisas e a formação em temas relacionados à sexualidade e a diversidade sexual, contexto que me trouxe a inquietante percepção de que a vida na rua Major Sertório pouco dialogava com o direito à saúde, equidade, participação e integridade preconizados nos princípios do Sistema Único de Saúde (SUS) ${ }^{4}$ e descritos nos inúmeros manuais de prevenção do HIV/AIDS.

No ano de 2008 comecei a trabalhar no Ministério da Saúde, na área de prevenção do HIV/AIDS do então "Programa Nacional de DST/HIV/AIDS”. Dentre outras atividades, fui designada para apoiar política e tecnicamente a implementação, nas 27 Unidades Federativas do país, dos "Planos Estaduais de Enfrentamento às DST/HIV/Aids e Hepatites Virais para Gays, HSH e Travestis" e dos "Planos Integrados de Enfrentamento à Feminização do HIV/AIDS". Tais políticas, que serão melhor apresentadas no decorrer deste trabalho, me permitiram conhecer um pouco mais a realidade de travestis e transexuais ${ }^{5}$ de diferentes regiões do Brasil. Nas oficinas realizadas para discussão das agendas de prevenção para as travestis relacionadas aos referidos Planos pude constatar que quando se trata de temas relacionados à saúde desta população, o desconhecimento é tão profundo que comumente a primeira pergunta dos

\footnotetext{
${ }^{4}$ Para dar materialidade à política de saúde, a Constituição Federal de 1988 instituiu o Sistema Único de Saúde (SUS), definido na Lei no 8.080/90, de 19/09/1990 (Lei Orgânica da Saúde), como o conjunto de ações e serviços de saúde prestados por órgãos e instituições públicas federais, estaduais e municipais, da administração direta e indireta e das fundações mantidas pelo poder público. De acordo com esta Lei (art. $7^{\circ}$ ), os principais princípios e diretrizes do SUS são: a universalidade de acesso; integralidade, entendida como conjunto articulado e contínuo das ações e serviços preventivos e curativos; preservação da autonomia das pessoas; igualdade, sem preconceitos ou privilégios de qualquer espécie; direito à informação, às pessoas assistidas, sobre sua saúde; utilização da epidemiologia para o estabelecimento de prioridades; e, especialmente, a participação da comunidade.

${ }^{5}$ Com muita frequência leigos e até mesmo especialistas têm se mostrado confusos diante dos diferentes significados das categorias denominadas por travestis, transexuais e transgêneros, pessoas trans, dentre outras. Com isso, é comum tratá-las como sendo a mesma coisa, ou confundido as três categorias, o que pode, sob nosso ponto de vista, produzir uma série de confusões relacionadas à pluralidade discursiva e de sentidos atribuídos a cada uma destas identidades. Dada a complexidade de categorias de análises possíveis sobre o universo do significado da expressão travesti, apresenta-se um panorama da questão nos próximos capítulos.
} 
participantes era: o que vem a ser "um travesti"? Em relação a esta pergunta, eu costumava contrapor com outra: "para vocês o que é UMA ${ }^{6}$ travesti”? Cena comum as pessoas iniciarem suas falas tentando descrever o tipo de roupa, os gestos, a linguagem e, sobretudo, a suposta incompatibilidade entre o sexo biológico e a performance de gênero; para muita gente as travestis seriam "homens que se vestem como mulheres", ou pior, "homens que tentam imitar mulheres". Nestas ocasiões sempre tive a impressão de que ao procurar descrever os adereços "femininos" que conformam certa inteligibilidade às travestis, as pessoas deslembram que, além de adereços femininos, tais corpos comportam subjetividades, desejos, sonhos e humanidade.

Neste trabalho propõe-se discutir os temas aids, bioética e travestis, não por imaginar que a aids seja para este grupo o maior dos seus percalços, tampouco por curiosidade acerca do universo "trans", mas sim por reconhecer a importância do trabalho do profissional de saúde pública como ator estratégico na dinâmica da epidemia de aids.

Neste sentido, me sinto comprometida com o fato da infecção pelo vírus HIV/AIDS ser um problema que afeta particularmente às travestis e que envolva grande complexidade, relacionadas a diversas violações de direitos, justiça social ${ }^{7}$ em saúde e vulnerabilidades, por exemplo. Entendo que a necessidade de suplantar tais desigualdades circunscreve este tema ao campo da bioética de intervenção, cujos estudos incluem os aspectos sociais da produção das doenças, constituindo-se como uma proposta de repolitização dos conflitos morais orientado pelo posicionamento favorável ao lado mais vulnerável "em face às múltiplas esferas do poder no âmbito social" (1).

Por entender a complexidade em relação ao significado da denominação "travesti", adoto a designação assumida em 2008 por uma representante destacada do movimento nacional de travestis, Keila Simpson, então presidenta da Articulação Nacional de Travestis e Transexuais (ANTRA). Ao ser questionada como se considerava, homem ou

\footnotetext{
${ }^{6}$ Adota-se o uso do artigo feminino para as travestis por estar de acordo com sua identidade de gênero e para atender às reivindicações dos movimentos nacionais LGBT.

${ }^{7} \mathrm{Na}$ linha do quanto proposto por Fulgêncio e Nascimento (2012 p.47) adota-se o entendimento da justiça social como uma resposta às injustiças causadas pelos diferentes modos de atuação dos poderes globais no âmbito da economia de mercado, que privilegia o capital e o individual em detrimento do coletivo, sendo que "a busca por justiça social, então, está completamente vinculada ao combate às iniquidades sociais que impactam o mundo da vida e da saúde".
} 
mulher, respondeu: "no atual momento, para a travesti, ser só homem ou só mulher é muito pouco".

O debate em torno das experiências das travestis desafiam as posições tradicionais de gênero e atravessam as dicotomias "masculino/feminino", "homem/mulher". Ao questionarem com a própria existência este modelo universalizante, hierarquizado e binário, desorganizam as normas de gênero e provocam um desajuste no discurso heteronormativo. Tais questões colocam para o campo da saúde (como para outros), o desafio de escapar a tais regimes e inscrever no campo das políticas públicas ${ }^{8}$ novas formas de acolher as demandas dos diferentes corpos e subjetividades, de modo que suas necessidades sejam legitimadas e contempladas e que o SUS aprimore os mecanismos voltados à universalização do direito à saúde.

Neste trabalho, parto da ideia de que as políticas de prevenção do HIV/AIDS para travestis e demais pessoas trans ${ }^{9}$ requerem um sistemático questionamento do modelo binário que tem desenhado as políticas atuais, tais como: masculino/feminino ou homossexual/heterossexual. A recusa social em relação a determinadas expressões de gênero e sexualidades, que não repousam sobre uma identidade supostamente natural (homem ou mulher), leva a situações de invisibilidade, estigma, violência e abandono, posicionando as travestis como um dos grupos mais vulneráveis e susceptíveis à infecção pelo vírus HIV/AIDS. Segundo Goffman (2), estigma é uma característica que torna o indivíduo "diferente de outros que se encontram numa categoria em que pudesse ser incluído, sendo, até, de uma espécie menos desejável, num caso extremo, uma pessoa completamente má, perigosa ou fraca".

Considerando, a partir do arcabouço da DUBDH, que indivíduos e grupos de vulnerabilidades específicas devem ser protegidos e a integridade individual de cada um

\footnotetext{
${ }^{8}$ Neste trabalho entende-se a formulação de políticas públicas como o processo por meio do qual os governos traduzem seus propósitos em programas e ações, que produzirão resultados ou as mudanças desejadas no mundo real (183).

${ }^{9} \mathrm{O}$ termo "pessoas trans" será utilizado quando estiver se referindo às mulheres transexuais e às travestis de forma abrangente. Este termo foi escolhido por representantes dos movimentos nacionais de travestis, numa reunião em que estive presente, por ocasião da revisão do documento da atenção integral em saúde. para transgêneros (Diretrizes para Profissionais de Saúde, 2013). De acordo com Schramm, Roland, et. al, (2011), o prefixo trans, de origem latina trans, indica "além de", "para lá de", "depois de", referindo-se, portanto, a um terceiro termo indentitário de difícil colocação lógica e semântica, pois indica ao mesmo tempo uma disjunção e uma conjunção, ou seja, algo que não é nem um nem outro e, ao mesmo tempo, um e outro, visto que "transitar" implica em princípio poder ir de um lado para o outro e vice-versa. Essa
} 
deve ser respeitada, assim como deve ser respeitado o princípio da dignidade humana, no qual o valor incondicional do homem é reforçado com a exigência de sua inviolabilidade, pode-se supor que a partir da ética da responsabilidade, a maior vulnerabilidade vivenciada por travestis seria um fator de solidariedade e igualdade em relação a outros indivíduos, mas, ao contrário disso, ser travesti é um fator de diferenciação e acréscimo de vulnerabilidades, uma vez que estas, na maior parte das vezes, são percebidas como ameaça, vetor de doença, sobretudo quando se trata do vírus HIV.

Neste trabalho é particularmente interessante pensar de que forma as práticas preventivas em HIV/AIDS podem reificar fatores de vulnerabilização das travestis, pela não observância de suas especificidades, assim como dos aspectos éticos como a integridade (coerência de vida), dignidade (valor intrínseco) e autonomia (autodeterminação).

Sob a perspectiva da DUBDH, os estudos sobre vulnerabilidades, violências, bioética de intervenção, pesquisas em bases internacionais e nacionais sobre prevalência do HIV/AIDS entre pessoas trans, assim como a análise das respostas governamentais para suas demandas realizadas neste trabalho, indicam que a invisibilidade das travestis realça a negação da humanidade, a segregação e a violência às quais estão submetidas. No campo das políticas de prevenção do HIV/AIDS, ainda que se apontem esforços governamentais no sentido de responder a alta prevalência do HIV nesta população, "há problemas estruturais que precisam ser superados", conforme aponta Mello, Luiz, et al. (3) se pretendemos superar os obstáculos ao enfrentamento da epidemia concentrada e ao acesso universal aos serviços de saúde de qualidade para a população de travestis no Brasil.

Do ponto de vista teórico-metodológico, esta pesquisa adota o método de pesquisa qualitativa, utilizando a perspectiva teórica da "hermenêutica-dialética". Para Minayo (4), a pesquisa qualitativa em saúde trabalha com significados, motivações, aspirações, crenças, valores e atitudes, o que corresponde a um espaço mais profundo das relações e processos sociais e dos fenômenos, que não podem ser reduzidos à operacionalização de variáveis. Tal perspectiva teórica apresentada por Minayo (5) propõe a descrição e interpretação de alguns sentidos que a leitura de um conjunto de "texto" pode suscitar, haja vista que toda leitura é uma interpretação, não existindo uma leitura única e 
objetiva da realidade. Importante notar que as representações sociais se constituem em uma referência essencial e indispensável à pesquisa social, pois apreendidas a partir de condutas, ideias, imagens e visões de mundo dos atores sociais que, em grande parte, expressam-se através da linguagem do senso comum. Assim, devem ser analisadas a partir da compreensão das estruturas e dos comportamentos sociais que, segundo a Autora, são ao mesmo tempo ilusórias, contraditórias e verdadeiras.

A escolha da hermenêutica-dialética como método também considera a importância da reflexão a respeito da realidade social estar ancorada na práxis; a junção das duas abordagens possibilita que a análise da realidade seja ao mesmo tempo compreensiva e crítica, conforme a Autora. O método hermenêutico-dialético entende que embora não exista uma verdade essencialista, o investigador deve buscar o sentido daquilo que o sujeito quis expressar, daí a necessidade de que o investigador perceba, na investigação, a importância de evidenciar as razões do autor, mantendo uma atitude crítica diante dos fatos analisados. Desta maneira, a Autora sugere a associação da hermenêutica com a dialética, por entender a existência de uma complementaridade, tendo em vista que:

"Enquanto a hermenêutica busca as bases dos consensos e da compreensão na tradição e na linguagem, o método dialético introduz na compreensão da realidade o princípio do conflito e da contradição como algo permanente e que se explica na transformação" (6)

Com efeito, a hermenêutica-dialética se apresenta como um meio necessário para produção de saber em relação aos processos sociais, e, consequentemente, em relação aos processos de saúde/doença. E embora os dois métodos - hermenêutica e dialética tenham sido desenvolvidos em movimentos filosóficos diferenciados, um pressupõe o outro, pois, segundo Stein (7), trazem em seus núcleos concepções semelhantes em relação à importância de considerar, durante a análise, as condições históricas e a noção da não existência do observador imparcial ou de que haveria ponto de vista fora da realidade e da história; ambos acreditam no investigador como "ferramenta do pensamento", pois o consideram parte da realidade que investiga, assim como questionam o tecnicismo como percurso capaz de realizar a compreensão e a crítica dos processos sociais, referindo a práxis como local de compartilhamento entre o mundo observado e os sujeitos da pesquisa com o mundo da vida do investigador. 
Para compreensão do estado da arte dos estudos sobre o tema investigado, foram realizadas buscas em bases eletrônicas utilizando os descritores "travestis", "pessoas trans", "transgêneros", "identidade de gênero", “aids e travestis", "prevenção do HIV, aids e travestis", "LGBT", "Bioética", "Declaração Universal de Bioética e Direitos Humanos". As bases de dados utilizadas foram: Sistema de Publicação de Teses e Dissertação da Biblioteca Central da UNB, Base de dados da Cátedra Unesco de Bioética; Biblioteca Digital Brasileiras de Teses e Dissertações (BDTD); bases de dados ScieLo (Scientific Eletronic Library Online); Biblioteca Virtual de Saúde (BVS); Base de dados do Programa Regional de Bioética da Organização Pan Americana de Saúde (OPAS).

Para a análise das atividades propostas pelo Ministério da Saúde para as travestis entre os anos de 2008 a 2011 optou-se por mapear as atividades voltadas para tal grupo que constam nos planos estaduais de Enfrentamento ao HIV/Aids entre gays, HSH e travestis nas 27 unidades federativas, com base na análise dos documentos disponíveis no site do Departamento de DST, HIV, Aids e Hepatites Virais do Ministério da Saúde $^{10}$. A primeira etapa do proesso de análise das atividades propostas se deu a partir da leitura nos 27 Planos priorizando a identificação daquelas voltadas a prevenção, promoção e assistência ao HIV/AIDS relacionadas às travestis, marcador que foi usado para selecionar tais ações.

Após a primeira leitura dos planos estaduais foram estabelecidas cinco categorias, a partir dos princípios norteadores do SUS: 1) Fortalecimento e Participação da Sociedade Civil; 2) Educação em saúde - incluindo a formação de recursos humanos; 3) Integralidade da assistência no cuidado; 4) Comunicação; 5) Ações específicas para travestis (apêndice 01). As atividades propostas nos 27 planos estaduais relacionadas às cinco categorias elencadas acima, foram analisadas a luz da bioética de intervenção e da DUBDH.

Afim de verificar a relação entre "bioética e travestis", foram consultados 1.115 periódicos, livros, dissertações e teses no campo da bioética, disponíveis na biblioteca

\footnotetext{
${ }^{10}$ Os planos podem ser consultados no endereço eletrônico: http://bvsms.saude.gov.br/bvs/publicacoes/plano_enfrentamento_epidemia_aids_hsh.pdf. Acessado em 21/10/2014.
} 
da Cátedra Unesco de Bioética, referente ao período de 1990 a $2013^{11}$, a partir dos descritores: "bioética e relações de gênero", "bioética e identidade de gênero", "bioética e diversidade sexual", "bioética e homossexualidade", "bioética e travestis", "bioética e transexuais", "bioética e transgêneros".

Nesta consulta, me pareceu que a bioética não tem se ocupado do tema "travestis" com a devida importância, resultando uma lacuna de publicações que tratem do tema e as poucas existentes relacionam as travestis com HIV/AIDS, direitos LGBT (de maneira geral) e/ou com as mulheres transexuais, esta última mais expressivamente. Vale mencionar que grande parte dos trabalhos referem-se às travestis e transexuais com base na Classificação Estatística Internacional de Doenças e Problemas Relacionados com a Saúde da OMS (CID-10) ${ }^{12}$, no qual tanto a transexualidade quanto a travestilidade são definidas como um transtorno de identidade sexual; diferente das travestis, às mulheres transexuais é atribuído uma espécie de "alma feminina" ou a noção de que "nasceram num corpo errado", portanto, o desejo pela intervenção médica é apresentado como solução para o dito transtorno, daí que suas demandas são consideradas legítimas, desta maneira, questões como o direito ao uso do nome social, hormonioterapia, aplicação de silicone ou a cirurgia de transgenitalização são admitidas com legitimidade.

Já em relação às travestis, os textos revisados atribuem patologização e inferiorização de suas práticas e vivências. Ancorados na perspectiva reducionista e arbitrária, o "travestismo" ainda é enquadrado como parafilia, termo contemporâneo para a perversão junto a outras práticas e expressões da sexualidade, associadas ao desvio de conduta, como, por exemplo, a pedofilia e o exibicionismo. Além disso, os textos revisados no campo da bioética, em sua maioria, desconsideram o acúmulo de estudos etnográficos que demonstram que ser travesti não significa simplesmente "vestir roupas do sexo oposto" e que as alterações em seus corpos são permanentes e dão sentido a sua existência, e mesmo sem sentirem necessidade de realizar a mudança da genitália para "solucionar" um suposto transtorno de identidade, suas demandas, por exemplo, por

\footnotetext{
${ }^{11}$ Tomo a data de 1990 a partir do marco de fundação da Sociedade Brasileira de Bioética (SBB). A pesquisa foi realizada em julho de 2013.

12 A Classificação Estatística Internacional de Doenças e Problemas Relacionados com a Saúde da OMS (CID-10) foi adotada com vistas a padronizar e catalogar as doenças e problemas relacionados à saúde, tendo como referência a Nomenclatura Internacional de Doenças [citado em 2014 Nov.3]. Disponível em: http://www.datasus.gov.br/cid10/V2008/cid10.htm.
} 
hormonioterapia, uso do nome social, dentre outras, precisam ser consideradas como um direito à equidade, à autonomia e a dignidade humana.

Para cumprir os objetivos propostos, o presente trabalho foi desenvolvido a partir do primeiro capítulo, quando se percorre a reflexão de diferentes teóricos sobre o entendimento a respeito de corpo, gênero, sexualidades e normas, problematizando a essencialização das identidades de gênero ${ }^{13}$. Também se apresenta neste capítulo um breve histórico sobre a (in) definição da categoria travestis em suas diferentes abordagens.

O segundo capítulo apresenta o marco teórico adotado como referência para a discussão sobre travestis e o HIV. Tomam-se como categorias centrais de análise a Bioética de Intervenção, a Declaração Universal de Bioética e Direitos Humanos e o conceito de vulnerabilidade, tanto a abordagem da bioética quanto aquela utilizada nos estudos relativos a aids, problematizando a relação entre as vulnerabilidades e as situações de exposição ao vírus HIV entre travestis.

O terceiro capítulo trata das diferentes violações dos direitos humanos que persistem em atravessar os cotidianos das travestis, evidenciando como tais experiências compõem um território de medo e terror atrelado à expectativa de morte e ao risco de adoecimento em decorrência da aids, compondo suas experiências subjetivas, incluindo o processo de saúde e doença.

No quarto capítulo são apresentados os resultados de estudos nacionais e internacionais que investigam os contextos de vulnerabilidades entre pessoas trans, bem como a prevalência do HIV/AIDS fazendo dialogar os nexos de causalidade entre as dinâmicas sociais e o elevado risco para o HIV entre pessoas trans.

No capítulo seguinte se apresenta um breve histórico das políticas nacionais de saúde relacionadas às travestis elencando várias iniciativas, com destaque para os Encontros Nacionais de Travestis e Transexuais na Luta contra a Aids e os Planos Nacional e Estaduais de Enfrentamento ao HIV/AIDS entre gays, HSH e travestis.

A partir do delineamento conceitual, do posicionamento político das travestis, da minha

\footnotetext{
${ }^{13}$ Neste trabalho entendemos identidade de gênero como as várias formas de viver a masculinidade ou a feminilidade.
} 
própria experiência profissional e dos dados e informações coletadas, apresenta-se a conclusão do trabalho de pesquisa, evidenciando as travestis como um grupo particularmente afetado pelo HIV/AIDS, contexto que demanda políticas específicas para o enfrentamento deste agravo, tudo isto à luz dos princípios da Bioética que se conformam como ferramentas fundamentais para qualificar as respostas governamentais. 


\section{A NORMA POSTA EM CHEQUE}

\subsection{QUESTIONANDO MODELOS}

Neste capítulo procura-se problematizar como a noção da heterossexualidade compulsória e o binarismo de gênero se traduzem, no campo da saúde e mais especificamente no campo da aids, em práticas distantes das múltiplas necessidades de travestis em relação ao enfrentamento desta doença. Parte-se da ideia de que as políticas públicas para travestis e demais pessoas trans demandam o questionamento do modelo binário que tem desenhado as políticas atuais, tais como: masculino/feminino ou homossexual/heterossexual. Para tanto, percorre-se as reflexões de diferentes teóricos ${ }^{14}$ que discutem a concepção de corpo regulada pelo binarismo de gênero, no qual o sistema "sexo/gênero" se baseia num determinismo biológico dissimulado por uma contribuição da cultura.

A cultura ocidental moderna tem operado dentro de uma lógica binária, que parte de uma ideia fundante e elege o seu oposto subordinado, sendo que o termo inicial será compreendido como superior, enquanto o outro seria seu "derivado", a exemplo da ideia da heterossexualidade como "normal/norma", e desejável, em uma suposta oposição à homossexualidade, tida como "anormal e patológica". Para questionamento desse modelo vigente, adota-se aquilo que Wanderson Flor do Nascimento (8) chama de "uma experiência crítica do pensar", que se refere a um tipo de movimento de desconfiança e desfamiliarização, um exercício de estranhamento capaz de nos livrar da "servidão imposta por práticas, pensamentos ou qualquer outra instituição".

Ainda que se constatem avanços nesta direção, como a regulamentação do nome social no $\operatorname{SUS}^{15}$, o problema da transfobia é uma realidade cotidiana que precisa ser

\footnotetext{
${ }^{14}$ Autores como Judith Butler, Guacira Louro, Berenice Bento, Richard Miskolci, Fernando Pocahy que têm em comum a utilização do referencial teórico baseado na teoria pós-estruturalista francesa e na desconstrução como um método de crítica literária e social, a partir da ideia de que o social deve ser criticado e interpretado de modo que os conhecimentos e as hierarquias sociais dominantes possam ser contestadas.

${ }^{15}$ O Ministério da Saúde, através da Portaria ${ }^{\circ} 1.820$, de 13 de agosto de 2009, estabelece (Art. $4^{\circ}$ ) que toda pessoa tem direito ao atendimento humanizado e acolhedor, realizado por profissionais qualificados, em ambiente limpo, confortável e acessível a todos. Sendo direito da pessoa, na rede de serviços de saúde, ter atendimento humanizado, acolhedor, livre de qualquer discriminação, restrição ou negação em virtude de idade, raça, cor, etnia, religião, orientação sexual, identidade de gênero, condições econômicas ou sociais, estado de saúde, de anomalia, patologia ou deficiência, garantindo-lhe a identificação pelo nome e sobrenome civil, devendo existir em todo documento do usuário (a) um campo para se registrar o
} 
superada $^{16}$, uma vez que reflete o modelo hegemônico de pensamento e sustentação dos processos de exclusão a determinados grupos sociais, como as travestis, que continuam sendo associadas a situações de delito, pecado, vício e patologia. Para Raupp Rios (9) os termos "transfobia" (transexuais) e "lesbofobia" (lésbicas) derivam do termo "homofobia", que significa a modalidade de preconceito e de discriminação contra homossexuais. O autor assinala que o termo foi produzido no cenário norte-americano na década de 1960 para "identificar os traços da personalidade 'homofóbica", ganhando foros acadêmicos e mais tarde dando origem a outros termos que apontam para a especificidade de outras experiências além da homossexual masculina. Daí terem surgido termos como a transfobia, utilizada neste trabalho como uma aversão sem controle, repugnância, ódio, preconceito contra pessoas e grupos com identidades de gênero travestis, transgêneros ${ }^{17}$ e transexuais, também denominados população trans. Assim, a transfobia ocorre não somente pela orientação sexual, mas também pela desigualdade entre os sexos e os gêneros, ou seja, direciona-se àqueles que não regulam suas relações e seus modos de subjetivação às normas de sexo/gênero/desejo/práticas sexuais.

Segundo Leone (10), a travesti se constitui a partir de um ato transgressor, não porque queira necessariamente, mas porque não tem opção, já que se torna imperativo contrariar a norma e transgredir a constituição corpórea, dada biologicamente, para poder adequar o aspecto de seu corpo ao que ela sente e deseja. Ocorre que neste caso a "transgressão", relacionada ao ato de tornar-se uma travesti, é percebida por grande

social, independente do registro civil, assegurando-se a identificação pelo nome social de preferência da cidadã, não podendo ser identificada por número, ou código da doença ou outras formas desrespeitosas ou preconceituosas. Vale acrescentar que desde 2009 vários estados e municípios têm aprovado decretos e leis com relação ao uso do social das pessoas travestis e transexuais, principalmente nas escolas e serviços de saúde.

${ }^{16}$ Dados levantados pelo Grupo Gay da Bahia (GGB) apontam que no ano de 2009 cerca de 200 homossexuais foram assassinados em todo o Brasil. Segundo a pesquisa da Secretaria de Direitos Humanos, no Brasil as travestis são o grupo de pessoas que mais sofre violência entre a população LGBT. [citado em 2014 Out. 10]. Disponível em http://gplaneta.blogspot.com.

${ }^{17} \mathrm{O}$ termo transgêneros é definido como uma terminologia que engloba tanto as travestis quanto as transexuais, os transgêneros seriam homens no sentido fisiológico, que se relacionam com o mundo como mulher. Neste trabalho utilizarei a definição amplamente utilizado em textos internacionais que engloba vários "transgêneros" para definir, de modo geral, travestis, transexuais, transformistas, drag queens, cross-dressers, andróginos, sendo que qualquer um desses sujeitos podem ser tanto homossexual, como heterossexual. 
parte da sociedade como algo ruim que deveria ser evitado, corrigido e/ou remediado; a partir dessa chave de entendimento justificam-se violências e/ou ausência de cuidados na saúde para com estas pessoas, consideradas "anormais". Para Butler (11), apontar alguém que escapa da norma heterossexual como "estranho", "anormal”, é uma forma de torná-lo menos humano, cabendo-lhes o lugar de marginais.

A concepção patológica atribuída à travesti reproduz relações de poder e de dominação de diversas matizes, tais como, de classe, étnico/racial e, sobretudo, de gênero, que, segundo Joan Scott (12), constitui uma forma primária de dar significado às relações de poder. De toda forma, a travestilidade nos permite questionar o pressuposto de que todas as pessoas sejam naturalmente heterossexuais e que o sexo biológico conformaria necessariamente uma identidade de gênero masculina ou feminina, nunca ambas ao mesmo tempo. Para maior compreensão desta temática, recorre-se inicialmente aos estudos feministas sobre gênero que problematizam, a partir de uma perspectiva oposicional, binária e de caráter universal, questões como a naturalização da mulher enquanto subalterna ao homem, por uma suposta condição biológica. Simone de Beauvoir (13), por exemplo, procurou "desnaturalizar" a identidade feminina, afirmando que não se nasce mulher, torna-se mulher. Contudo, "desnaturalizar" não é sinônimo de "dessencializar", conforme nos alerta Bento (14), na medida em que se questionam os interesses que dispõem a mulher como "inferior ao homem", por uma presumida condição biológica, as posições universalistas acabam reforçando a “essencialização" dos gêneros e tendem a "cristalizar as identidades em posições fixas", supondo uma humanidade binária, dividida em duas categorias de indivíduos supostamente "universais": os homens e as mulheres.

Neste modelo, o corpo é entendido como uma espécie de "folha em branco", no qual o "gênero" viria a "dar forma e significado", dependendo da cultura e do momento histórico, levando a essencialização das identidades. Nesta perspectiva, é importante incluir as contribuições trazidas pelos estudos sobre masculinidades, que apresentam uma nova perspectiva para a concepção de gênero, ao conceber a construção do masculino e do feminino de maneira relacional, simultânea e complexificadora; os autores Carrigan, Connel e Lee $(1985)^{18}$ propõem um modelo de masculinidades em

\footnotetext{
${ }^{18}$ Para maior aprofundamento sobre o questionamento de reivindicações universalizantes relacionadas com as hierarquias de gênero, sugere-se a leitura das feministas Maxine Baca Zinn (184) e Angela Davis
} 
multiplas relações de poder e incluem nesta discussão o entendimento de que dimensões de classe social, local de moradia, geração, etc., atravessam as relações de gênero forjando contextos específicos na formulação de desigualdades sociais.

Neste contexto é importante frisar também a contribuição de pesquisadoras "feministas do patriarcado" tais como Goode 1982 (15), Snodgrass 1977 (16), Tolson 1977 (17) que ao debater o entrelaçamento de marcadores sociais de diferença na expressão da masculinidade também procuram problematizar o papel do homem na transformação do sistema patriarcal. Além disso, teóricas feministas antirracistas, conhecidas a partir do conceito estadunidense como 'mulheres de cor' - como Angela Davis, Maxine Baca Zinn e Bell Hooks também passam a criticar o apagamento de questões raciais relacionados ao chamado "feminismo hegemônico" nos quais o poder é unicamente conceituado em termos de diferenças de sexo, preparando, desse modo, o terreno para o questionamento de quaisquer reivindicações universalizantes sobre a categoria de homem.

Nesta perspectiva, Joan Scott (18) propõe que o conceito de "gênero" seja abordado de forma sistêmica, uma vez que se articula com o conhecimento sobre as diferenças sexuais, históricas e culturais. Gênero, segundo a autora, é uma categoria construída numa determinada conjuntura histórica que atravessa todas as relações que compõem as sociedades "generificadas", organiza as relações de poder a partir dos significados que cada sociedade atribui à diferença sexual, isto é, não somente entre os sexos, mas também entre sujeitos do mesmo sexo. Continua a Autora, informando que ao atribuir significados distintos para a diferença sexual, categorizando e valorizando diferentemente atributos femininos e masculinos, a sociedade tende a transformar tais diferenças em desigualdades que se expressarão em todas as dimensões da existência humana, inclusive no modo de adoecer e de morrer.

Tal concepção descrita por Scott, embora reconhecida como contribuição fundamental aos estudos de gênero e sexualidade, é contestada por Butler (19), que reavalia os pressupostos teóricos que fundamentam o campo dos estudos de gênero, problematizando a essencialização das identidades de gênero, que pressupõe o mundo em conformidade com uma matriz universalizante, hierarquizada, binária e diferenças de classe e demais privilégios. 
dicotomizada dos gêneros a partir de um marcador essencialmente heterossexual, a Autora demonstra que o "corpo-sexo" não pode ser pensado como uma "folha em branco", ao passo que é "pré-discursivo"19, tampouco "gênero" pode ser entendido como um construtor posterior que daria forma e significado a este corpo inerte.

Para Judith Butler (19), gênero deve ser tomado como um "fazer performático",20, no qual uma série de ações e expressões, tais como mover-se, andar e gesticular de uma determinada maneira, consolidam a noção de tratar-se de "um homem" ou "uma mulher". Desta forma trata-se o "ser homem" ou "ser mulher" como se fosse uma verdade consolidada, sucedida do "corpo-sexo" supostamente natural. Ao contrário disso, Butler entende que "ser homem" ou "ser mulher" é um fenômeno produzido e reproduzido, a todo o tempo, por meio das "interpretações em atos das normas de gênero" 21 que fazem com que o corpo adquira uma "aparência" coerente com o sexobiológico. Neste sentido:

A performatividade deve ser compreendida não como um 'ato' singular ou deliberado, mas, ao invés disso, como a prática reiterativa e citacional pela qual o discurso produz os efeitos que ele nomeia (...) as normas regulatórias do 'sexo' trabalham de uma forma performativa para constituir a materialidade dos corpos e, mais especificamente, para materializar o sexo do corpo, para materializar a diferença sexual a serviço da consolidação do imperativo heterossexual (20).

Também para Louro (21), as concepções sobre o "corpo" estão fundamentadas na

\footnotetext{
${ }^{19}$ Para Butler J, desde o nascimento o corpo está inscrito num determinado campo discursivo, no qual as expectativas em relação ao sexo de nascimento irão gerar uma série de atos, comportamentos e esperanças. Portanto, para a Autora, não existe um corpo pré-discursivo, pré-social ou que esteja imune a relação de poder-saber.

${ }^{20}$ Na obra da filósofa Judith Butler "Cuerpos que importan: sobre los limites materiales y discursivos del
sexo" escrito em 2002, os termos "gênero" e "performatividade" são conceitos importantes que partem
do entendimento de que gênero é um conjunto de atos repetidos dentro e um modelo regulatório bastante
rígido, na qual a identidade é estabelecida pelas reiterações das próprias expressões de gênero. A
"performatividade" constituída "na" e "pela" linguagem é um ato que faz manifestar o que nomeia. Não
há uma encenação cotidiana de performance corporal, tal como um ator, pois segundo Butler o homem é
ao mesmo tempo "aquele que se presume ser" tanto quanto, "aquele que esta submetido a diferentes
regras que o precedem". A luz de Foucault, Butler situa a identidade de gênero como uma espécie de
paródia produzida em determinados contexto e relações de poder, desta maneira, quando as normas de
gênero são incorporadas o resultado é a produção de corpos que expressam essas normas. Logo para
Butler os gêneros são apenas efeitos de verdade. Por fim, o conceito de "performaticidade" chama a
atenção para o caráter construído de todas as identidades, sobretudo, daquelas de caráter mais estável.
}

${ }^{21}$ Para maiores informações sugere-se a leitura de Butler J. Cuerpos que importan: sobre los limites materiales y discursivos del sexo. Buenos Aires: Paidós; 2002. 
suposição de que todas as pessoas, universalmente, vivenciariam seus corpos e sua sexualidade da mesma maneira. Para a autora, tanto a sexualidade quanto a concepção de corpo não são dadas pela natureza, ocorrem a partir de processos culturais e plurais que envolvem rituais, fantasias, símbolos, representações e convocações. A partir de tais processos definimos o que é ou não é "natural", produzimos e transformamos natureza e a própria biologia. $\mathrm{O}$ registro nos corpos dos gêneros (femininos ou masculinos) é determinado pelas "marcas" de uma dada cultura, que estabelecem as diferentes possibilidades da sexualidade e da expressão dos desejos.

Somos condicionados a compreender estas marcas e decodificá-las, aprendemos a classificar os sujeitos pela maneira com que os corpos se apresentam. Portanto, entendese que a "identidade de gênero e sexual" não diz respeito a algo que se é desde o nascimento, mas a algo que se faz. Desta maneira, conforme assinala Louro (22), as identidades de gênero e sexuais são determinadas e conformadas por relações sociais e pelas redes de poder de uma dada sociedade, que, presentemente, acredita num corpo "inequívoco" e "evidente por si”, capaz de inferir uma identidade de gênero, de marcas biológicas, sem ambiguidades. Para a autora, a construção de uma identidade de gênero ocorre de forma muito mais complexa e a dedução linear "corpo/identidade" (femininas ou masculinas), em muitas ocasiões, pode estar equivocada. E, se o corpo é significado pela cultura, as identidades de gênero, supostamente "naturais", também podem ser alteradas, a exemplo das travestis, mulheres e homens transexuais (21).

Assim como o corpo, em nossa sociedade, a heterossexualidade também é concebida como "natural", "universal" e "normal", acredita-se que todos os indivíduos tenham, de maneira inata, propensão para eleger como objeto amoroso e sexual alguém do sexo oposto, de modo que quaisquer outras formas de sexualidade são significadas como "antinaturais", “anormais" e "peculiares". No entanto, para que o indivíduo permaneça no sistema binário sexual e na matriz heterossexual é necessário que as normas que regulam e materializam o "sexo-gênero" dos indivíduos se estabeleçam, sejam reiteradas e policiadas permanentemente, para isso recorre-se às diferentes práticas formais e informais de vigilância e punição, deflagradas tanto pelos poderes institucionais (a exemplo das instituições psiquiátricas), quanto por práticas informais (hostilizações, bulling, discriminação, por exemplo), assentados no pressuposto da indigência de "normalização" (20). 
Ainda que as referidas normas sejam ratificadas e endossadas a todo instante, a existência de corpos que escapam e não se ajustam às mesmas, tais como travestis e transexuais, são importantes para reafirmar e definir, por contraposição, uma referência para a heterossexualidade, já que as travestis passam a ser percebidas, conforme discutese a seguir, como a materialização do fracasso do "homem de verdade", tomando emprestado um termo de Leandro Oliveira (23): “é o fantasma contra o qual a masculinidade dos homens se delineia".

Os processos de reconhecimento das identidades passam pela constatação da diferença, que implica no estabelecimento de desigualdades, ordenamentos e hierarquias que estão engendradas em redes de poder de uma dada sociedade. O reconhecimento do outro que não partilha dos atributos que possuímos ocorre a partir do lugar social que ocupamos. Assim a sociedade demarca e circunscreve contornos entre aqueles que representam a "norma" e os "outros", que ficarão às suas margens por não estarem em conformidade com as "normas" estabelecidas por padrões culturais que, em nossa sociedade, historicamente nos remetem ao homem colonial, branco, heterossexual, proveniente da classe média ou alta urbana e preferencialmente cristão. Tais normas posicionam este sujeito como referência e os demais como "os outros", rotulados a partir desta referência. Segundo Louro (22):

Desta forma, a mulher é representada como 'o segundo sexo' e gays e lésbicas são descritos como desviantes da norma heterossexual. Os grupos sociais que ocupam as posições centrais, 'normais' (de gênero, de sexualidade, de raça, de classe, de religião, etc.) têm possibilidade não apenas de representar a si mesmos, mas também de representar os outros. Eles falam por si e também falam pelos 'outros' (e sobre os outros); apresentam como padrão sua própria estética, sua ética ou sua ciência e arrogam-se o direito de representar (pela negação ou pela subordinação) as manifestações dos demais grupos (22).

Importante ressaltar também que as identidades sexuais ${ }^{22}$ são políticas, haja vista que a forma como se representam ou são representadas, bem como os sentidos e significados atribuídos às suas experiências e práticas, são demarcadas e atravessadas por relações de poder e por um regime de "verdades" que se assentam num pressuposto de

\footnotetext{
${ }^{22}$ Aqui as identidades sexuais se referem às classificadas pelo movimento social e comunidade médica por meio da sigla LGBT: lésbicas, gays, travestis e transexuais.
} 
"normalidade" ou de "desvio". A recusa social em relação a determinadas expressões de gênero e sexualidades que não repousam sobre uma identidade supostamente natural (homem ou mulher), tal como as expressões de gênero e sexualidade vivenciadas por travestis e transexuais, leva a situações de invisibilidade, violência e abandono.

É possível resistir a tais regimes e inscrever no campo das políticas públicas formas de acolher as demandas dos diferentes corpos e subjetividades de modo que suas necessidades sejam legitimadas e contempladas?

Como superar a visão míope de uma sociedade que, atada às lentes da patologia, prescreve estratégias e políticas públicas que excluem parte da sociedade cujos corpos e subjetividades se situam fora do imperativo heterossexual?

Para Butler (24), é imprescindível ampliar o limite das análises que destacam a divisão sexual como uma estrutura binária entre sexo/natureza e gênero/cultura, de modo a enfrentar os interesses da chamada matriz heterossexual, que a mesma Autora, em outro momento, designa como a base cultural através da qual se naturalizam corpos, gênero e desejos. Esta seria a matriz que define e regula o modelo discursivo/epistêmico hegemônico da inteligibilidade de gênero, "inteligibilidade esta que é decidida antes de toda decisão individual” (25), a qual supõe que para o corpo ter coerência e sentido deve haver um sexo estável, que se expressa mediante um gênero estável, isto é: masculino expressa homem-biológico, ao passo que feminino expressa mulher-biológica.

Em outras palavras, espera-se que o sexo (biológico) tenha coerência com o gênero (feminino ou masculino) e que este "naturalmente" determine o desejo e a prática sexual pelo sexo oposto, a partir do par indentitário masculino/feminino entendido de forma complementar e, inevitavelmente, heterossexual ${ }^{23}$. Nesta matriz, institui-se a inteligibilidade dos sujeitos e o reconhecimento como humano dentro dos "marcadores reprodutivos" e no "dimorfismo sexual" (26).

Neste trabalho, tais questionamentos mostram-se particularmente importantes na medida em que as experiências das travestis desafiam as posições tradicionais de gênero

\footnotetext{
${ }^{23}$ Neste caso o gênero pode ser pensados como uma sofisticada tecnologia social heteronormativa por meio da qual, diferentes instituições como escolas, família, estado, produzem corpos-homens e corposmulheres, com disposições "naturais" para a heterossexualidade. Ao assumir o sexo biológico como um "definidor natural de identidade (feminina ou masculina) se produz e reproduz a classificação dos sujeitos baseados no "princípio de inteligibilidade para os seres humanos" de modo que a ligação sexo, gênero e sexualidade pareça indissociável e precisa. In Bento B. A reinvenção do corpo: sexualidade e gênero na experiência transexual. Editora Garamond; 2006. p. 87.
} 
e atravessam as dicotomias "masculino/feminino" e "homem/mulher". Ao questionarem com a própria existência este modelo universalizante, hierarquizado e binário dos gêneros, desorganizam as normas de gênero e provocam um "desajuste" no discurso heteronormativo que faz com que travestis não sejam consideradas "vidas legítimas".

\subsection{TRAVESTIS: (IN)DEFINIÇÃO DE CATEGORIAS}

Nas últimas décadas tem-se multiplicado as categorias adotadas para nomear sujeitos designados como gays, lésbicas, travestis, transexuais, transgêneros, entre outros. Os diferentes termos adotados pela comunidade científica e pelos movimentos sociais mudam de acordo com os autores e as instituições que as definem, sem, contudo, haver um consenso entre as diferentes áreas da ciência sobre suas definições e significados (Leite, Jr) (27). Por exemplo, alguns autores usam o termo "transgêneros" para se referir a travestis e transexuais, enquanto outros usam a nomenclatura "pessoas trans".

De acordo com os autores Carvalho (28) e Costa (29) na década de 60 o termo "travesti" não era compreendido como uma categoria indentitária ${ }^{24}$, mas sua terminologia estaria enraizada no modelo dicotômico "bichas e bofes", também associada a outras denominações: "bicha espalhafatosa", "bicha pintosa" ou "bicha fechativa".

O termo travesti surge com mais vigor no final da década de 50, quando homens gays realizavam festas e concursos nos quais as denominadas "bichas" travestiam-se com indumentárias femininas. O registro desta prática é descrito por Green et. al (30), quando discorrem sobre os carnavais do Rio de Janeiro, focando os "Bailes de Travestis", nos quais os chamados "travestidos" eram considerados sinônimos dos homossexuais.

Na década de 60, seguindo o "modelo igualitário" apresentado por Peter Fry (31) (explicitado adiante), surge a categoria identificada como "entendidos", proposta como forma de eliminar a dicotomia "bicha/bofe", pois ser "entendido" não estaria relacionado aos tradicionais papéis de gênero exercidos durante a relação sexual, pelos quais a figura feminina (bicha) exerceria um papel passivo, receptivo e dócil, enquanto a figura masculina (bofe) exerceria um papel ativo, viril e protagonista.

\footnotetext{
${ }^{24}$ Segundo Carvalho, 2011 a categoria indentitária 'travesti' é relativamente mais moderna que a categoria 'homossexual', segundo o autor é nos anos 1970, que se projetam gays de uma lado e travestis de outro.
} 
Esta nova proposta identitária foi rechaçada pelas chamadas "bichas"25 que acusavam os "entendidos" de serem "bichas enrustidas", enquanto os "entendidos" acusam as "bichas" de prejudicarem a aceitação social da homossexualidade "por agirem de forma efeminada e exagerada" (32). Nesse contexto, predomina o entendimento de que agir de forma afeminada e exagerada prejudicaria a aceitação social e a respeitabilidade da homossexualidade:

Se a proposta de conquista de respeitabilidade social está associada a uma ruptura da relação entre homossexualidade e feminilidade, as figuras que mantêm tal relação se tornam personificações do estigma homossexual (33).

No contexto brasileiro, o autor exemplifica tal situação na representação da travesti pelo senso comum, como último passo no desenvolvimento de uma "carreira homossexual". Evitar a "efeminação exacerbada", no final da década de 60, era percebido como um ingrediente necessário para o reconhecimento de direitos civis dos homossexuais. Os avanços políticos e a respeitabilidade social estariam atrelados a uma apresentação "respeitável" e "masculina" da homossexualidade.

Já na segunda metade da década de 1970 as discussões sobre as minorias - negros, índios, mulheres, homossexuais - ficaram subordinadas a questões mais amplas, relacionadas com a democratização do País, já que nesta época havia uma preocupação sobre constituir ou não uma identidade homossexual e uma inquietação sobre uma possível reificação da oposição hétero/homossexualidade e das possibilidades de se constituírem novas formas de estigmatização e marginalização (34).

A percepção negativa sobre a representação de travestis no Brasil também foi relatada por Cristina Câmara (35), em análise do discurso proferido em 1987 por um dos propulsores do ativismo LGBT no Brasil, João Antônio de Souza Mascarenhas, o qual afirmou existir dois tipos de homossexuais, "o homossexual comum" e "as travestis", estas últimas estariam envolvidas com a prostituição e práticas ilegais relacionadas a latrocínios e drogas, diferente dos primeiros. Passadas três décadas do referido discurso

\footnotetext{
${ }^{25}$ Estudo recente aponta que a distinção entre "macho" e "bichas" ainda aparece como elemento problemático, no qual a valorização do "masculino" se ratifica na desvalorização do que é considerado afeminados ou bichas. In: Facchini R., França I. Convenções de gênero, sexualidade e violência: pesquisa com participantes de eventos do Orgulho LGBT de São Paulo. Latitude. 2013 v.7, Suppl 1:11.
} 
de Mascarenhas, etnografias recentes envolvendo travestis e transexuais têm evidenciado que tais grupos ainda são assinalados como "putas" ou "loucas", seja por "operadores dos saberes científicos ou em situações de trocas de acusações mútuas" (36). Segundo as autoras, a acusação de "puta" pode estar vinculada à condição de mau comportamento sexual da mulher, o que justificaria toda a sorte de violências a que são submetidas.

Neste estudo não se pretende aprofundar a discussão sobre as possíveis definições da categoria "travesti", mas por se tratar do "sujeito" do trabalho, será apresentada a problematização envolvida nesta conceituação, privilegiando a designação adotada por representantes destacadas do movimento nacional de travestis, conforme veremos abaixo. Entretanto, ressalto a concordância com Peres e Toledo (37), que compreendem que nenhuma categoria deve ser assumida como verdadeira ou absoluta, uma vez que estão orientadas e são produzidas num determinado contexto histórico e político no qual interesses diversos disputam o campo do saber. Além disso, é preciso considerar, conforme Pelúcio (38), os marcadores sociais da diferença, já que o sujeito social é culturalmente construído em tramas discursivas nas quais gênero, raça, religião, nacionalidade, sexualidade e geração não são variáveis independentes. Entendemos que ao rol elencado acima, é importante destacar também o marcador classe social, uma vez que autores como Teixeira, F. (39); Leite Jr (40); Barbosa (41), têm demonstrado que no Brasil o termo travesti está estreitamente relacionado a grupos sociais com baixo poder econômico, e ainda que nem todas as travestis brasileiras encontrem-se situadas nesta categoria, o grupo é frequentemente associado à pobreza e miserabilidade.

O termo travestis intersecciona marcadores sociais (acima relacionados), concepções midiáticas, concepções locais (a partir de expressões nativas de cada região), além das categorias científicas classificadas em função das diversas abordagens teóricas/ideológicas. Embora o uso do termo "travesti" no Brasil não se refira ao conceito clínico de "travestismo", este termo é classificado pela CID 10 (OMS) ${ }^{26}$ na categoria "transtorno de identidade sexual", onde o "travestismo bivalente" implica no uso de vestimentas do sexo oposto para satisfação da experie $\square$ ncia temporária de

\footnotetext{
${ }^{26} \mathrm{~A}$ CID-10 apresenta os códigos e a tipificação das doenças que devem ser indicados em todos os diagnósticos para que tenham validade legal. [citado em 10/10/2014]. Disponível em: http://cid10.bancodesaude.com.br/cid-10/.
} 
pertença ao sexo oposto, mas sem desejo de alteração sexual mais permanente ou de transformação cirúrgica; por sua vez, o "travestismo fetichista" foi incluído na categoria "transtorno da preferência sexual", descrito como o habito de vestir roupas do sexo oposto, principalmente com o objetivo de obter excitação sexual e de criar a aparência de pessoa do sexo oposto. Nesta última categoria o travestismo fetichista também é entendido como um dos "transtornos múltiplos da preferência sexual", que inclui ainda pedofilia, exibicionismo, sadomasoquismo, etc.

Por sua particular associação com as travestis (embora não seja o objeto deste trabalho), vale referir que o termo "transexual", em 2012, foi substituído por "disforia de gênero", nos casos em que há uma incongruência marcante entre a própria experiência de gênero e o sexo do nascimento, com base no Manual Diagnóstico e Estatístico de Transtornos Mentais - DSM- $5^{27}$. Ou seja, a não conformidade entre sexo biológico e gênero ainda é vista na concepção científica como uma patologia, apesar de não apresentar qualquer outro fundamento psicopatológico. Importante ressaltar, conforme assinala Leite Jr. (42), que tais categorias foram criadas pelo discurso da ciência e como tal abrigam o pressuposto da universalidade e atemporaneidade, alcançada por meio de verificação empírica que desconsidera a impossibilidade da uniformidade entre as pessoas trans, bem como o contexto histórico e regional. Na trajetória de atuação junto a trabalhadores da saúde e ao movimento LGBT, atentei que o termo travesti é muitas vezes empregado por representantes do movimento social e por trabalhadores da saúde de maneira bastante particular e algumas vezes imprecisas. Como exemplo, aponta-se uma apresentação feita por uma representante do movimento de travestis no "XX Encontro Nacional de Travestis e Transexuais na Luta contra a Aids - ENTLAIDS" realizado em $2013^{28}$, no qual a participante se auto intitulou “mulher-travesti”. Outro exemplo, agora relacionado aos profissionais de saúde, ocorreu numa reunião do Ministério da Saúde cuja pauta eram as terminologias para travestis e transexuais que seriam utilizadas nas fichas do SINAN ${ }^{29}$, a maioria dos participantes desconhecia a profunda e permanente

\footnotetext{
${ }^{27}$ Para maiores informações sugere-se consultar: "A nova classificação americana para os transtornos mentais: o DMS-5". (186).

${ }^{28}$ Participei do encontro em 2013 como assessora técnica do Departamento de DST, HIV, Aids e Hepatites Virais (MS) em uma mesa cuja discussão versava sobre a prevenção das DST, HIV e Aids entre travestis.

${ }^{29}$ Sistema de Informação de Agravos de Notificação (SINAN): contém informações sobre todos os agravos de notificação compulsória no Brasil, com o objetivo de fornecer dados para caracterizar o perfil
} 
transformação implicada em "ser travesti" e, de um modo geral, associaram equivocadamente a noção simplista de que travestis seriam homens que se vestem com roupas e adereços femininos, algo efêmero, uma fantasia que se coloca ou se retira ao chegar em casa, ao passo que as transexuais seriam mulheres que nasceram num corpo masculino e que requerem intervenções cirúrgicas corretivas.

Corroborando com tal percepção, Leite Jr. (43) destaca que a questão entre quem pode ser nomeado como travesti ou transexual é um debate não apenas científico, mas também político, já que tais terminologias podem se alterar a depender da ocasião/situação e do contexto político. Para o autor, o uso da terminologia travesti no Brasil é bastante peculiar, uma vez que aqueles sujeitos que o senso comum denomina popularmente como uma "pessoa travesti", por adotar gestos, roupas, expressões do gênero feminino, bem como sofrer intervenções hormonais e cirúrgicas permanentes, pode ser classificada nos manuais médicos dentro da categoria "transexual".

Vale ressaltar que tanto do ponto de vista científico quanto popular, a distinção entre o que seja uma travesti ou uma mulher transexual é geralmente compreendida pelo desejo das mulheres transexuais em se submeter a uma cirurgia de transgenitalização ${ }^{30}$, assim como pelo sentimento de mal estar/inadaptação em referência ao seu próprio sexo anatômico. Neste sentido:

\begin{abstract}
Muitas travestis modificam seus corpos por meio de hormonioterapia, aplicações de silicone e/ou cirurgias plásticas, porem, vale ressaltar que isso não é regra para todas. Diferentemente das transexuais, as travestis não desejam realizar a cirurgia de redesignação sexual (mudança de órgão genital) (44).
\end{abstract}

Todavia, entende-se que nem todas as pessoas que se auto identificam como mulheres transexuais buscam tal intervenção ou sentem aversão pelo próprio sexo anatômico.

\footnotetext{
de morbidade vigente. No caso particular da aids, as informações que alimentam o SINAN são provenientes das notificações de casos confirmados como aids, conforme classificação adotada no país. O sistema contém informações epidemiológicas relevantes, que têm sido utilizadas para caracterizar a dinâmica temporal da epidemia de aids, assim como para subsidiar as ações de vigilância, prevenção e controle da doença no Brasil. [Citado em 17/08/2014]. Disponível em: http://dtr2004.saude.gov.br/sinanweb/.

${ }^{30}$ Possibilidade de intervenção médica para a transmutação do sexo (biológico) masculino para o feminino, conhecida popularmente como "mudança de sexo". Para mais informações consultar a Portaria n 2.803 , de 19/11/2013.
} 
Tais considerações remetem à necessidade de observar com cautela às tentativas de homogeneização das singularidades da vivência particular de toda e qualquer pessoa, incluindo as travestis e mulheres transexuais ${ }^{31}$.

Ainda na discussão sobre a distinção entre "ser mulher", "ser travesti” ou "ser mulher transexual", a pesquisadora Flavia Teixeira (45), explicita em sua tese uma passagem ocorrida em 2007, no XIII ENTLAIDS, os movimentos nacionais de travestis e transexuais trouxeram como uma das preocupações a delimitação de fronteiras entre as travestis e as mulheres transexuais, ilustrando com o exemplo do desafio lançado por uma integrante do Coletivo Nacional de Transexuais (CNT) às travestis: "somos todas mulheres?". A presidente da ANTRA, em resposta, contestou: "não somos homens, não somos mulheres, somos travestis e queremos ser respeitadas como travestis que somos".

Vale notar que também no campo das politicas publicas de enfrentamento do HIV/Aids esta distinção se reflete no desenvolvimento de estratégias de enfrentamento da epidemia, conforme detalhado no capitulo XX, durante a elaboração do "Plano Nacional de Enfrentamento da Epidemia de Aids e DST entre Gays, outros Homens que fazem Sexo com Homens (HSH) e Travestis" é acatado pelo Programa Nacional de DST, HIV, Aids do Ministério da Saúde a reinvindição do "movimento nacional de travestis e do "movimento nacional de mulheres transexuais", que as ações propostas para travestis deveriam ser alocadas no Plano referido acima, enquanto as ações de enfrentamento da aids para mulheres transexuais comporiam uma das agendas afirmativas do "Plano Integrado de Enfrentamento da Feminização do HIV/Aids e outras DST".

Na mesma linha, o pesquisador Leandro de Oliveira (46) defende o posicionamento da não reinvindicação de travestis na categoria "mulher", afirmando que "as travestis não se percebem como, nem desejam tornar-se, 'mulheres', mas percebem-se ao menos em parte 'femininas' e consideram essa feminilidade como um valor a ser perseguido".

Segundo Teixeira (47), tais questões mostram-se relevantes para a compreensão destas categorias, uma vez que problematizam a ideia de que as travestis se posicionariam na

\footnotetext{
${ }^{31}$ Para maior aprofundamento sobre a temática sugere-se a leitura de pesquisadores que tem produzidos importantes conceitos sobre esta temática, como Marcos Benedetti; Tiago Duque; Dom Kulick; Larrisa Pelucio; Flavia Teixeira; dentre outros.
} 
categoria de homens; ao contrário disso, a pesquisadora acredita que travestis estão nesta fronteira, "reivindicam o pênis sem necessariamente evocar a posição de homem, construir um corpo feminino deslocado do status de mulher e transitar nos dois gêneros colocariam as travestis num outro projeto de reconhecimento que não inclui o ingresso nos coletivos feministas".

Por fim, sendo a preocupação central desta pesquisa o entendimento acerca das políticas públicas de prevenção do HIV/AIDS junto a travestis, utilizaremos a "categoria travesti" estabelecida em março de 2009 pela Articulação Nacional de Travestis e Transexuais $^{32}$ (ANTRA) e referendada no "XVI Encontro Nacional de Travestis e Transexuais na Luta contra a Aids" (ENTLAIDS), por considerar a importância e legitimidade deste movimento na busca por respostas às suas demandas no campo das políticas públicas. Assim, o conceito de travesti está compreendido neste estudo, nos seguintes termos:

Uma construção de gênero feminina/masculino, oposto a sexo de nascimento, seguida de uma construção física, de caráter permanente, que se identifica na vida social, familiar, cultural e interpessoal através desta identidade (48).

Ao adotar tal definição apresentada pelo movimento de travestis, aproxima-se da perspectiva de Judith Butler (49):

\begin{abstract}
No meu entender, a tarefa de todos estes movimentos consiste em distinguir entre as normas e convenções que permitem às pessoas respirarem, desejarem, amarem e viverem, e aquelas normas e convenções que restringem ou cortam as condições da vida. As vezes as normas funcionam de ambas as formas de uma só vez, e em outras ocasiões funcionam de uma maneira para um determinado grupo e de outra maneira para outro grupo. O mais importante é deixar de impor para todas estas vidas o que é habitável só para alguns e, de forma similar, abster-se de prescrever para todas as vidas o que é invisível para alguns. As diferenças entre a posição e o desejo marcam os limites da universalidade com um reflexo ética. A crítica às normas de gênero deve situar-se no contexto das vidas como se vive e deve guiar-se pela questão de se maximizar as possibilidades de uma vida habitável, que minimize as
\end{abstract}

\footnotetext{
${ }^{32}$ Segundo Cris Stefani, então presidenta da ANTRA, a instituição foi idealizada em 1993 e atualmente conta com mais de 105 instituições de travestis e transexuais filiadas em todo o Brasil. Tem como finalidade principal a luta pelos Direitos Humanos de travestis e transexuais contra quaisquer formas de discriminação jurídicas, socias, políticas, educacionais, religiosas, culturais ou econômicas [Citado em 10/11/2014]. Disponível em: http://luisastern.com/2013/12/09/nota-da-antra-sobre-o-plc-722007/.
} 
possibilidades de uma vida insuportável, inclusive da morte social e literal (50).

Neste sentido, em entrevista ocorrida em setembro de 2008, Keila Simpson, então presidenta da ANTRA, foi questionada pelo apresentador Jô Soares: "você se considera homem ou mulher?" Ao que respondeu: "No atual momento, digo que, para a travesti, ser só homem ou só mulher é muito pouco"33.

A fala de Keila Simpson coloca para o campo da saúde (como para outros) o desafio de lidar com a construção de estratégias em saúde que dialoguem com indivíduos cujos corpos e subjetividades não se conformam com as normas de gênero, que pressupõe que o corpo original, biológico, determinaria um gênero, feminino ou masculino, e que este, por sua vez, determinaria desejos e sexualidades.

Os processos de transformação corporais das travestis são atravessados por diferentes tecnologias, tais como o uso de hormonioterapia, cirurgias plásticas, uso de silicone, entre outras, tais recursos tecnológicos possibilitam visualizar que todos os corpos, não só o das pessoas trans, são, em certa medida, estabelecidos artificialmente por meio de gestos aprendidos como femininos ou masculinos, roupas, cortes de cabelo, e outros trejeitos associados ao papel de cada gênero.

O estranhamento relacionado aos "corpos trans" ocorre tanto pela constatação de que é possível inscrever novos sentidos e significados aos artifícios que constroem os corpos, entendidos como "naturalmente femininos ou masculinos"; quanto pelo questionamento das normas que instituem a inteligibilidade: "sexo, gênero, sexualidade/desejo". Neste sentido, segundo Butler:

Essa produção constringida funciona ligando a categoria do sexo com a da identidade; haverá dois sexos, distintos e uniformes, e eles vão se expressar e se tornar evidentes no gênero e na sexualidade de modo que qualquer manifestação social de não identidade, descontinuidade ou incoerência sexual será punida, controlada, repudiada, reformada (51).

\footnotetext{
${ }^{33}$ Programa de Auditório exibido pela Rede Globo de Televisão no dia 03/09/2008. [citado em 2015 maio 5]. Disponível em: http://video.globo.com/Videos/Player/Entretenimento/0,GIM877780-7822 KEILA+SIMPSON+DEFENDE+OS+DIREITOS+DOS+TRAVESTIS,00.html
} 
A "punição, o "repúdio" e o "controle" citados por Butler podem ser entendidos também como violência transfóbica, conforme discutido anteriormente, pois se baseia na percepção negativa da diferença e nos descaminhos decorrentes da exclusão social estabelecida na "matriz heterossexual". Na linha de Louis-Georges Tin (52), entende-se neste trabalho que o tratamento discriminatório relacionado às travestis não se definem, a priori, em função de uma sexualidade específica (homossexual, bissexual, heterossexual), a transfobia ocorre em decorrência de uma dada forma de sexualidade "humilhada pelo modelo heterossexual", manifesta a hostilidade e aversão em relação a indivíduos cuja identidade confunde os parâmetros dos papéis sócio-sexuais e transgredem as fronteiras entre os sexos e entre os gêneros.

Para Barboza e Soares (53), as questões acima relacionadas fazem com que as travestis sejam consideradas marginais, desviantes e perigosas, portanto, dividir espaço público com tais pessoas também pode ser considerado inaceitável e a violência um recurso justificável, entendida, inclusive, como uma espécie de mecanismo de controle apropriado para a garantia da "limpeza social e da ordem moral que harmoniza a sociedade" (Barboza e Soares). Na mesma direção segundo Spagnol:

Nos discursos das autoridades responsáveis pela 'manutenção da ordem', esses grupos são sempre desqualificados socialmente como imorais, anormais, merecedores de punição, como a necessidade de internação em alguma instituição de saúde, ou simplesmente sua eliminação do espaço público. É comum a prática da violência contra homossexuais em vias públicas, ou mesmo no interior de lojas, bares e coletivos urbanos. E essa violência vai desde a agressão verbal até a física, quando grupos de pessoas se unem para expulsar ou espancar homossexuais, principalmente travestis, em algum local público. Inclusive com a aquiescência de inúmeros outros indivíduos que testemunham a ação, mas que não conseguem perceber a injustiça do ato cometido. Tal é a introjeção dos estereótipos elaborados pela maioria, em relação às minorias (54).

Assignadas ao nascer como do sexo masculino, as travestis são classificadas primeiramente como homossexuais, também como homens desavergonhados, efeminados, promíscuos e inadequados. O comportamento compreendido como impróprio para "sujeitos homens" reflete a cultura patriarcal, sexista e heteronormativa pela qual se entende como "natural" que pessoas designadas ao nascimento pelo sexo masculino (biológico), assumam características ou papeis sociais que se contraponham às características ou papeis sociais reservados às mulheres. Quanto mais "estes" se 
distanciam do que se entende como próprio a "estas", maior será a possibilidade de terem a sua masculinidade atestada e consequentemente acender às vantagens advindas do pertencimento ao regime de gênero, possíveis mediante a adoção de uma série de comportamentos e atitudes idealizados na cultura atual e modulados nos valores tradicionais como "tipicamente masculinos" e, ainda que de modo prolixo e distinto nas diversas camadas sociais, corresponder a estes ideais seria uma maneira de garantir a manutenção de privilégios e poder, conforme Pedro Paulo de Oliveira (55).

Para poder reatualizar as qualidades típicas de quem é digno delas, é necessário cumprir algumas exigências e provar sua competência como reprodutor do regime de gênero mediante a adoção de comportamentos tipicamente masculinos (56).

Esta percepção guarda relação com as formulações de Butler (57), para quem o pavor do desejo homossexual, para um homem, pode conduzir ao terror de ser considerado feminino e feminilizado, passível de nem mesmo ser considerado um homem, passando a ser compreendido como um homem falido. Tal descrição nos remete ao conceito de "masculinidade hegemônica", tratado por Connell (58), no qual infringir padrões e referenciais socialmente legitimados para a vivência do masculino, levariam o sujeito a uma relação de subordinação, cumplicidade ou marginalização em relação à masculinidade hegemônica. Neste sentido, é possível afirmar que as travestis, ao transformarem e transgredirem suas determinações biológicas e sua socialização de gênero, desestabilizam a matriz binária de gênero e não deixam de ser subalternizados e rechaçados, tanto por homossexuais "não afeminados" quanto por heterossexuais.

Neste contexto, Peter $\mathrm{Fry}^{34}$, mencionado anteriormente, descreve três sistemas taxonômicos relacionados a construção histórica da homossexualidade no Brasil e que estariam diferencialmente disseminados no País. No primeiro modelo, designado como "modelo hierárquico", a hierarquia de gênero articula-se a partir da oposição "masculinidade/atividade" no comportamento sexual em comparação à feminilidade/passividade no comportamento sexual, sendo que a categoria "homem" abarcaria todos os indivíduos do sexo masculino que mantivessem relações sexuais na "posição ativa" com homens e/ou mulheres. Aqui os homens sexualmente passivos eram tratados como "viados" e "bichas". $\mathrm{Na}$ dicotomia entre homens e bichas, os

\footnotetext{
${ }^{34}$ Para maior informação sugere-se a leitura de Peter Fry. Para inglês ver. Identidade e política na cultura brasileira. Rio de Janeiro, Zahar; 1982.
} 
primeiros são valorizados por seu comportamento ativo durante o ato sexual, e os segundos, "as bichas", desvalorizados pela associação com o feminino, "as famosas almas femininas em corpos masculinos" correspondente a um comportamento "sexual passivo", a dicotomia "bicha" e "bofe" segue os padrões impostos pelo modelo heterossexual, produzindo identidades complementares e hierarquicamente divididas. $\mathrm{O}$ segundo sistema, estabelecido principalmente pela comunidade médica/científica, estabelece que independentemente da posição (ativa ou passiva) assumida durante o ato sexual, seriam considerados homossexuais qualquer homem que mantivesse relações sexuais com outros homens. Neste sentido, se mantém a oposição hierárquica "heterossexuais" em oposição aos "homossexuais", sendo os primeiros considerados "normais" enquanto que os segundos são considerados anormais, desviantes e doentes (59). Por fim, no terceiro modelo, conhecido como "modelo igualitário", ainda que se mantenha o sistema "hétero vs. homossexualidade" questiona-se a posição hierárquica e a marca de "anormalidade" ou patologia atribuída à homossexualidade, posição assumida pelos movimentos sociais LGBT.

Os questionamentos trazidos no decorrer deste capítulo são relevantes ao revelar que o HIV/AIDS entre travestis está visceralmente relacionado com os processos de exclusão, estigmatização e violência, baseados na noção universalizante, binária e heteronormativa de corpo e da sexualidade. Essa produção discursiva em torno de uma sexualidade e identidade sexual indesejada performa nas travestis a diminuição da autoestima e a redução da capacidade para traçar/alcançar objetivos pessoais e o menor acesso a estratégias de saúde compatíveis com suas necessidades específicas, conformando, consequentemente, um contexto de maior vulnerabilidade e risco para o HIV/AIDS. Conforme se verá a seguir, os contextos de vulnerabilidades são múltiplos e complexos, não restritos ao campo individual, ao contrário, fatores estruturais e sociais alicerçam o atual cenário epidemiológico para o adoecimento e morte em decorrência do HIV/AIDS. 


\section{TRA VESTIS E VULNERABILIDADES}

\subsection{VULNERABILIDADES: UM OLHAR A PARTIR DA DUBDH.}

Neste capítulo propõe-se compreender, a partir da minha experiência profissional e ancorada nas leituras realizadas sobre as temáticas relacionadas ao campo da saúde, bioética e dos direitos humanos, o que posiciona as travestis como o grupo mais vulnerável e susceptível à infecção pelo vírus HIV, ao mesmo tempo se entenderá como as vulnerabilidades são percebidas dentro dos marcos da bioética e dos estudos relacionados com a aids.

As vulnerabilidades das travestis não são comparáveis a outros segmentos populacionais considerados, de uma maneira geral, como iguais, caso dos gays e dos $\mathrm{HSH}$, tendo em vista que cada travesti tem referências próprias sobre a construção e desconstrução de corpos, vivência peculiar das identidades de gênero e das práticas sociais e eróticas.

Neste sentido, vale observar que o Ministério da Saúde tem utilizado a categoria "homossexual" abrangendo tanto gays e HSH, quanto travestis. Já em relação às transexuais, o Ministério tem trabalhado no sentido de incorporar esta categoria às políticas da área técnica da saúde da mulher, conforme mencionado no "Plano Integrado de Enfretamento a Feminização da Aids", reconhecendo a identidade feminina deste segmento ${ }^{35}$. Entretanto, segundo o "Relatório de Monitoramento da Implementação dos Planos Integrados de Feminização da Aids e outras DST", desenvolvido pela Dra. Wilza Villela (2007), "nas políticas locais, nos municípios e Estados, tanto travestis quanto transexuais são tratadas por gestores públicos e pela própria sociedade dentro da categoria de homossexuais" ${ }^{\text {"36 }}$. Ocorre também que muitos dados e propostas de intervenção em saúde relacionadas às travestis são obtidas através de pesquisas junto a gays e HSH; mesmo sem negar a existência de vivências comuns

\footnotetext{
${ }^{35}$ O Departamento de DST/HIV/AIDS estabeleceu em 2007 o "Plano Integrado de Enfrentamento às DST/HIV/Aids para mulheres em 2007" para prevenção das DST/ HIV/Aids e Hepatites Virais, no qual se inclui o segmento das mulheres transexuais; em 2008 lançou o "Plano Nacional de Enfrentamento da Epidemia de Aids e das DST entre gays, homens que fazem sexo com homens (HSH) e travestis" no qual se insere o segmento populacional de travestis. [Citado em 2014 Nov. 24]. Disponível em: www.aids.gov.br.

${ }^{36}$ Relatório de monitoramento do Plano Integrado de Enfrentamento da Feminização das DST/HIV/Aids 2008 e 2009. [Citado em 2014 Nov. 24]. Disponível em: www.aids.gov.br/feminização.
} 
entre estes últimos e as travestis, é necessário estabelecer e identificar também o que é específico para estas, de modo que as práticas de promoção e prevenção das DST/HIV/AIDS ${ }^{37}$, sejam estabelecidas a partir das necessidades específicas das travestis.

Conforme mencionado, as travestis trazem em si o estigma de um corpo modificado, a partir de uma ótica que foge aos modelos de sexualidade considerados normais e adequados (normativas de gênero); a fragilidade imposta pelo estigma de ser travesti implica numa relação de desigualdade e vulnerabilidades que impedem a vivência plena de suas potencialidades e projetos de vida, bem como acarretam na maior incidência do HIV/AIDS.

A partir da década de 1990 o conceito de vulnerabilidade tem sido amplamente discutido e valorizado no campo da saúde em geral e da bioética em particular. De acordo com Neves (60), a origem da palavra deriva de vulnus (eris), que significa ferida, definindo-se assim a susceptibilidade de ser ferido. A referida denominação, embora mantenha-se atual em todas as evocações do termo, pode assumir diferentes concepções e aplicabilidades, de acordo com o período e o contexto.

Segundo Godoi (61) e Neves (62), o termo vulnerabilidade é introduzido no âmbito da experimentação humana a partir do Relatório Belmont ${ }^{38}$, de 1978, seguindo as correntes de pensamento anglo-americanas da bioética, nas quais se entende a vulnerabilidade como atributo adjetivado, temporário, atual, uma característica particular e relativa, como é o caso das pessoas institucionalizadas e prisioneiros. Nestes termos, entende-se que a vulnerabilidade pode ser remediada ou mesmo superada mediante a proteção destes sujeitos, o referido relatório traz um elemento importante em termos éticos, pois a qualificação de pessoas como "vulneráveis" implicaria na obrigatoriedade ética da sua defesa e proteção para que não sejam feridas ou maltratadas.

\footnotetext{
${ }^{37}$ Em que pese a relevância do conjuntos das doenças sexualmente transmissíveis, estas não são objeto deste estudo, de forma que serão citadas apenas quando sua aplicação estiver estritamente relacionada com as questões do HIV/AIDS.

${ }^{38} \mathrm{O}$ relatório Belmont foi produzido para formular os princípios éticos básicos a serem respeitados em toda a investigação envolvendo seres humanos. Belmont Report: ethical principles and guidelines for the protection of human subjects of research. 1978
} 
Neste sentido, Beauchamp \& Childress, no "Principle of Biomedical Ethical"(63) de 1979, reforçam a ideia de que os vulneráveis devem ser protegidos e a vulnerabilidade enfrentada; importante notar que tal posicionamento está circunscrito no campo da experimentação científica, no qual os não vulneráveis seriam pessoas com capacidade de agir autonomamente de acordo com seus valores e crenças pessoais, podendo dar seu consentimento livre e esclarecido.

Outros importantes documentos internacionais de bioética, como o "Internacional Ethical Guidelines for Biomedical Research Involving Human Subjects" $(\mathrm{CIOMS} / \mathrm{WHO})^{39}$, em suas diferentes versões, também referem-se à noção de vulnerabilidade na sua função adjetivante, aplicadas a indivíduos, grupos $\mathrm{e}$ comunidades, especialmente relacionadas à investigação humana. Da mesma forma, na "Declaracion of Helsinki" 40 constata-se a ausência do termo vulnerabilidade, tanto no documento original, quanto nas subsequentes revisões em 1975, 1983 e 1989; contudo, na revisão de 1996, segundo Neves (64), no artigo $8^{\circ}$ o termo surge para classificar os sujeitos de investigação "em termos particulares e relativos e enunciando a necessidade da sua adequada proteção" e se mantém nas revisões posteriores.

Em 1997, na "Universal Declaration on the Human Genome and Human Rights" (65), a primeira declaração universal desenvolvida pela Organização das Nações Unidades para a Educação, a Ciência e a Cultura (UNESCO) ${ }^{41}$, os artigos 17 e 24 referem-se aos grupos particularmente vulneráveis, incluindo indivíduos e famílias, associando o termo a uma prática de solidariedade e a uma realidade que se quer suprimir e ultrapassar.

A partir da década de 80 com o desenvolvimento da bioética na Europa Continental, há uma forte alteração acerca do entendimento da noção de vulnerabilidade e o termo ganha novos sentidos a partir das contribuições de filósofos como Emmanuel Lévinas e Hans Jonas, citados por Neves (66) e Godoi (67), quando passa a ser entendido como uma condição humana universal, consolidando-se como um substantivo "constitutivo do

\footnotetext{
${ }^{39}$ Council for International Organizations of Medical Sciences. International ethical guidelines for biomedical research involving human subjects. International ethical guidelines for biomedical research involving human subjects. OMS; 1993.

${ }^{40}$ World Medical Association - WMA. Declaration of Helsinki. Ethical Principles for Medical Research Involving Human Subjects (Internet). Tokyo: WMA; 2004 [citado em 2013 Maio 5]. Disponível em Htpp:// www.wma.net/30publicacions/10policies/b3/index.html.

${ }^{41}$ Para maiores informações [citado em 2014 Out.12] Disponível em: http://www.unesco.org/.
} 
humano" e não mais como adjetivo.

De acordo com Neves (68), para Hans Jonas o caráter perecível de todo existente, de todo ser vivo, incluindo outras espécies, é mortal e, portanto, irredutivelmente vulnerável. Jonas situa o conceito no plano ético, onde a vulnerabilidade apela ao dever, ou seja, a uma resposta ética, responsabilizando o outro perante a ameaça de perecimento do existente (ele não se restringe ao humano ou as relações interpessoais), uma vez que, o homem, tal como os demais, é ontologicamente vulnerável, a vulnerabilidade é constitutiva do humano. Para este autor, os que mais podem são os que mais devem. Desta forma, sendo apenas os homens que detém o poder de destruir todo o existente, compete a ele a responsabilidade de zelar pela vulnerabilidade, de responder de modo proporcional ao seu poder. Assim compreende-se que a vulnerabilidade é ontológica, por isso não pode ser entendida ou utilizada como fator de diferenciação entre pessoas e populações. É uma característica de todo o ser vivente, portanto não pode ser ultrapassada ou eliminada.

Ainda segundo Neves (69), para Lévinas o Eu (subjetividade) está sempre em relação ao outro e posterior ao outro, que existe necessariamente antes do eu. Assim, o "eu” está sempre na dependência do outro, por isso a vulnerabilidade. Diferente de Hans Jonas, Lévinas acredita que a vulnerabilidade não define a subjetividade num plano ontológico (o ser em si mesmo) como sua identidade substancial, ou seja, a natureza humana, mas no plano ético; para este Autor, o Eu-subjetividade só surge a partir do outro, no relacionamento com o outro, e o indivíduo se relacionaria com o outro a partir de sua condição de vulnerabilidade (exposic $\square$ ão, ferida, sofrimento), ou seja, todos os seres, humanos ou não, são vulneráveis diante do outro, desta maneira o Eu não é a instância da vulnerabilidade, mas o Outro. E nesta relação sensível com o outro que se baseia a responsabilidade ética pelo Outro, assim a vulnerabilidade não pode ser subtraída ou eliminada, pois é parte da condição humana, que requer uma resposta ética, restando implícito o apelo a uma relação não violenta, imposta pela própria necessidade de sobrevivência do ser mortal que pode ser.

De acordo com Godoi (70), Lévinas e Jonas convergem na afirmação de vulnerabilidade enquanto condição humana e descrevem-na não como diferenciação, mas como fator de igualdade entre todo; como exemplo, segue trecho do pensamento de Lévinas e Jonas: 
Todos os seres, humanos e não humanos, são vulneráveis perante o outro, isto é, são passiveis de serem feridos nessa relação com o outro. $\mathrm{O}$ eu - a subjetividade - só emerge a partir do outro, na relação com o outro - a alteridade - e, portanto, esse eu nasce dependente do outro, no que reside a vulnerabilidade enquanto condição humana. Ela (a vulnerabilidade) não é mais entendida como um atributo passível de ser removido ou eliminado, passando a ser vista como inerente à condição humana, e que exige como resposta ética a responsabilidade com o outro, no sentido do estabelecimento de uma relação não violenta com o outro (71).

Deste modo, na concepção anglo-americana tem-se a vulnerabilidade como um atributo pessoal de diferenciação de grupos e pessoas, enquanto que na concepção europeia a vulnerabilidade é percebida como condição inerente ao ser humano. Segundo Neves (72) enquanto a concepção anglo-americana implica na exigência da autonomia e da prática do consentimento livre-esclarecido, a concepção europeia passa a requerer responsabilidade e solidariedade em relação aos vulneráveis.

No campo da aids, o grau de vulnerabilidade para a infecção pelo vírus HIV, conforme se verá adiante, é muito superior em alguns grupos populacionais como o das travestis, conforme orientação dos citados Levinas e Jonas, poderíamos supor que no plano ético a maior vulnerabilidade vivenciada por este grupo seria um fator de solidariedade e igualdade em relação a outros indivíduos, mas, ao contrário disso, ser travesti é um fator de diferenciação (de caráter negativo) e acréscimo de vulnerabilidades. Pela ética da responsabilidade, as travestis deveriam ser protegidas "pelos que mais podem", entretanto, na maior parte das vezes, são percebidas como ameaça, "vetor de doença", sobretudo quando se trata do vírus HIV, por conseguinte, muitas vezes, as práticas de prevenção visam proteger a "sociedade" em geral, em detrimento da proteção e bem estar deste grupo.

Parece interessante problematizar de que forma as práticas preventivas são passíveis de fortalecer a vulnerabilização das travestis pela não observância de suas especificidades, assim como dos aspectos éticos, como a integridade (coerência de vida), dignidade (valor intrínseco) e autonomia (autodeterminação). Concordando com Jungues (73), neste caso é importante ressaltar que a consideração com quem é vulnerável deve preponderar a qualquer outro princípio, por constituir-se na proteção da vida e das condições necessárias para que os seres humanos desfrutem-na de maneira íntegra e digna. 
Com a Declaração Universal de Bioética e Direitos Humanos (DUBDH), de 2005, o respeito pela vulnerabilidade humana e integridade pessoal constitui um dos 15 princípios éticos, conforme Art. $8^{\circ}$ :

Respeito pela vulnerabilidade humana e integridade pessoal. Na aplicação e no avanço dos conhecimentos científicos, da prática médica e das tecnologias que lhes estão associadas, deve ser tomada em consideração a vulnerabilidade humana. Os indivíduos e grupos particularmente vulneráveis devem ser protegidos, e deve ser respeitada a integridade pessoal dos indivíduos em causa.

De acordo com o citado artigo, tal princípio articula-se com o princípio da dignidade humana, no qual o valor incondicional do homem é reforçado pela exigência de sua inviolabilidade. A vulnerabilidade passa a ser entendida tanto como uma condição humana (sentido formal substantivo), quanto como uma condição na qual se reconhece que certos grupos e pessoas vivenciam questões particulares em termos de vulnerabilidade, como característica com função adjetivante mais restrita.

Para Almeida (74), o aspecto fundamental da vulnerabilidade como princípio ético seria o de formular essa obrigação de ação moral, ou seja, tanto se reconhece a obrigatoriedade da renúncia de qualquer ação que traga prejuízo a outrem, quanto a exigência de cuidado, vigília e consideração para com a vulnerabilidade intrínseca de cada indivíduo ${ }^{42}$. Concordando com o Autor, os próximos capítulos apresentarão as diferentes facetas da vulnerabilidade - daí que neste trabalho se utiliza o termo no plural, "vulnerabilidades" - que marcam os contextos de vida das travestis, refletindo sobre a obrigatoriedade da responsabilização do Estado e "dos que mais podem" no enfrentamento das vulnerabilidades relacionadas ao estigma e a discriminação deste grupo.

Vale notar que na DUBDH o princípio da vulnerabilidade também é citado nos seguintes itens: art. $6^{\circ}$, sobre consentimento livre; art. $7^{\circ}$, sobre pessoas e capacidade de consentir; no art. 10 que trata da igualdade, justiça e equidade; e no art. 11 sobre não discriminação ou estigmatização. A DUBDH é contundente em afirmar a função do Estado na promoção dos direitos fundamentais da pessoa humana, garantindo as

\footnotetext{
${ }^{42}$ Vale notar que a vulnerabilidade como princípio independe da autonomia e do consentimento, desta maneira, segundo Godoi AMM, 2014 retira-se o caráter restritivo ao qual lhe foi dado inicialmente pela bioética, que orientou os primeiros documentos referenciais e que se vinculava unicamente a situações de experimentação científica.
} 
liberdades, assim como a universalização do "Bem Estar Social", ou seja, igualdade de oportunidades, de ascensão social e econômica por meio de serviços educacionais, e a satisfação de necessidades básicas como alimentação, saúde, previdência, salário justo, etc.

Neste trabalho, o conceito de vulnerabilidade é vital para avaliar e propor medidas de proteção relacionadas à infecção e adoecimento pelo HIV/AIDS em travestis, maximizando os benefícios e reduzindo possíveis prejuízos, buscando a justiça social a partir da exigência da equidade na distribuição de serviços e oportunidades, que reverberam na inclusão das travestis nas políticas de saúde.

Entende-se a DUBDH como ferramenta essencial para este trabalho, uma vez que fornece as bases para problematização das questões sociais, ambientais e sanitárias nas situações cotidianas relacionadas com a exclusão social, discriminações de gênero, raça e equidade na distribuição de recursos, conforme Barbosa (75).

Concordando com Garrafa e Pessini (76), é essencial que a discussão "bio-ética" se incorpore ao próprio funcionamento do sistema público de saúde, com base na responsabilidade do Estado em relação a tal direito:

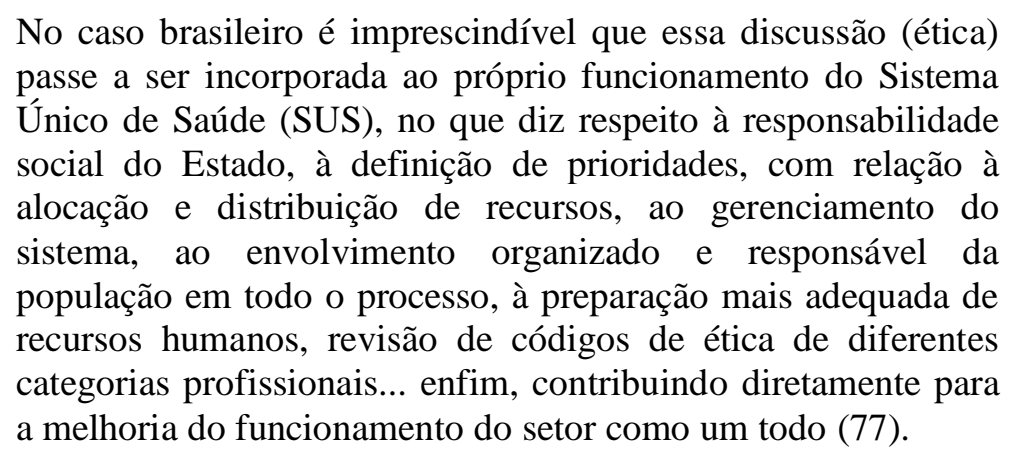

Tal abordagem se insere no campo da Bioética de Intervenção (78) e tem como norte a justiça social e a busca de respostas para os problemas persistentes, sobretudo nas regiões pobres e em desenvolvimento, como é o caso da África, América Latina e no próprio Brasil. O presente estudo alinha-se a esta perspectiva por reconhecer que a vulnerabilidade social incide sobre a estrutura e o modo de viver de indivíduos e comunidades e está relacionada a fatores como: distribuição desigual de riqueza, bens e serviços, desigualdade em relação ao acesso aos desenvolvimentos científicos e tecnológicos, menor participação social. Além disso, reconhece a particular associação com as discussões sobre justiça social, equidade e saúde, pois é partir da necessidade de 
respostas para os macro problemas enfrentados coletivamente que a bioética de intervenção propõe uma aliança concreta com os direitos humanos e consequentemente com o lado mais vulnerável da sociedade:

A Bioética de Intervenção tem como espelho a matriz dos direitos humanos contemporâneos. Afirmado pelo reconhecimento do direito coletivo a igualdade e pelos direitos dos indivíduos e grupos à equidade, incorpora o discurso da cidadania expandida, pelo qual os direitos estão mais além do que as garantias asseguradas pelo Estado (79).

Partindo da ideia de que o enfrentamento da aids demanda o rompimento de diferentes barreiras, relacionadas marcadamente ao estigma e a discriminação ${ }^{43}$, a bioética evidencia a justiça social, provocando o Estado a enfrentar heranças autoritárias, patriarcais, sexistas e homofóbicas, com vistas a submeter a lógica heteronormativa aos direitos sexuais e ao direito à autonomia em relação a autodeterminação de seus próprios corpos e a escolha da própria identidade de gênero. É imperativo ir além, com a transformação da lógica heterossexual na qual as políticas de saúde estão baseadas e que balizam o exercício da sexualidade e das relações afetivo-amorosas, mudança que exige a substituição do princípio da lógica dos controles dos corpos pela lógica da justiça $^{44}$ e o direito a autonomia.

Este enfrentamento passa pela necessidade de revelar estratégias políticas que contemplem a criação de normas, regulamentos e organizações de serviços que correspondam às necessidades de pessoas "trans", como por exemplo: o desenvolvimento e divulgação de materiais informativos (preventivos) que considerem também as práticas sexuais e o corpo das travestis; uso do nome social; desenvolvimento de pesquisas voltadas à vigilância e comprovação do número de casos de HIV/AIDS entre esta população.

A complexidade do problema exige respostas mais sofisticadas, a altura dos desafios

\footnotetext{
${ }^{43}$ Para Garrafa e Porto, referência acima, a ética tem uma importância aplicada no que se refere a "análise das responsabilidades epidemiológicas, sanitárias e sociais”, por isso o desenvolvimento de políticas públicas no campo da prevenção do HIV/AIDS passa pela necessidade de romper com diferentes barreiras relacionadas aos estigmas e a discriminação, fazendo-se necessário apelar para a justiça social.

44 O termo "justiça" está de acordo com o Art. 10 da DUBDH, sobre Igualdade, justiça e equidade, no qual a igualdade fundamental de todos os seres humanos em dignidade e em direitos deve ser respeitada para que eles sejam tratados de forma justa e equitativa.
} 
postos, daí a necessidade de articulação de atores diversos para ampliação do foco das respostas governamentais ${ }^{45}$. Essa articulação requer o envolvimento de outros setores do governo, para além do setor saúde (e para ser mais exato, para além do campo da aids), que deverão garantir políticas sociais capazes de interceder favoravelmente nos determinantes sociais, gerando mudanças efetivas na qualidade de vida e no nível de saúde da população LGBT, marcadamente das travestis.

A perspectiva da integralidade da atenção à saúde, a orientação sexual e a identidade de gênero constituem contextos de saúde bastante complexos e determinantes das diversas vulnerabilidades, não somente por implicarem em práticas sexuais específicas, mas sobretudo em decorrência dos processos de discriminação, estigma e exclusão social que violam os direitos humanos, dentre os quais o direito à saúde, à dignidade, à autonomia e ao livre desenvolvimento, na linha do quanto proposto pelo Departamento de Apoio à Gestão Participativa do Ministério da Saúde ${ }^{46}$. Necessário, portanto, confrontar a complexidade dos determinantes sociais da vida e da saúde das pessoas e coletividades, intervindo nos fatores que implicam na exclusão social.

Também é importante observar que a orientação sexual ou a identidade de gênero não devem ser pensados como únicos marcadores sociais, ou mesmo como marcadores universais, uma vez que se articulam de formas diversas com outros "atributos", como classe social, raça, local de moradia, faixa etária, etc. Conforme Costa e Ávila (80) e Piscitelli (81), a "interseccionalidade" de diferentes marcadores é uma característica fundamental para demonstrar como um mesmo sujeito social articula-se com diversos eixos de subordinação, de modo que exclusão e aceitação se distinguem a depender do contexto social no qual se encontram. Com efeito, todas as formas de discriminação como homofobia, machismo, racismo e misoginia devem ser consideradas condições produtoras de doença e sofrimento.

\footnotetext{
45 De acordo com Seara LN, 2011 em razão de tal complexidade, as respostas à epidemia da aids reclamam uma abordagem mais ampliada, que extrapole o âmbito da medicina/saúde coletiva, devendo-se considerar as questões políticas, sociais, culturais, jurídicas, econômicas e comportamentais. Por envolver discussões sobre a qualidade de vida, direitos humanos, orfandade, psicologia, economia, etc., o combate à aids exige uma complexidade de respostas que o Estado não seria capaz de prover isoladamente, daí que tenha se inaugurado no Brasil um modelo de articulação entre Estado e sociedade civil até então inédito no enfrentamento das questões de saúde (187).

${ }^{46}$ Esta discussão é apontada pelo Departamento de Apoio a Gestão Participativa da Secretaria de Gestão Estratégica e Participativa do Ministério da Saúde (188).
} 
Para que as ações no campo da prevenção do HIV/AIDS sejam eficazes é necessário que haja um alinhamento com outras esferas das políticas públicas e da vida social, de modo que as travestis sejam consideradas cidadãs plenas ${ }^{47}$ e possam apropriar-se de seus direitos nas diferentes esferas da sua existência, uma vez que para este grupo, muitas vezes, a aids é o menor dos problemas a ser enfrentado cotidianamente. As violações dos direitos humanos impostas pela heteronormatividade de uma sociedade patriarcal resultam na exclusão e na marginalização das travestis, obrigadas a se equilibrar entre situações que implicam na hierarquia do risco, que intersecionam fatores como: uma eventual morte ou enfermidade decorrentes do HIV/AIDS, situações limites de sobrevivência, fome e violências.

\subsection{VULNERABILIDADES: UM OLHAR A PARTIR DOS ESTUDOS SOBRE AIDS}

No campo da aids, a necessidade urgente de respostas relacionadas a eclosão da epidemia fez com que a comunidade científica incorporasse o conceito de vulnerabilidade (individual, social e programática) como alternativa às noções de "grupo de risco" $" 48$ e de "práticas de risco" das primeiras perspectivas sobre a doença, fazendo o contraponto à abordagem do estigma e do risco individual, conforme Paiva (82).

No início dos anos 80, a aids foi associada aos denominados "grupos de risco", nos quais a doença foi identificada inicialmente ${ }^{49}$; neste conceito estavam incluídos julgamentos morais, preconceitos e desinformação relacionados à ideia de que a

\footnotetext{
${ }^{47}$ Nancy Fraser, 2000 sugere o modelo do status, onde misrecognition (baixo ou pouco reconhecimento) e/ou maldistribution (distribuição desigual), isto é, qualquer fator que impeça a participação do sujeito na vida social como um par, em iguais condições de acesso aos bens e oportunidades (dentre os quais a pobreza e a marginalização econômica e sociais), afrontam a cidadania plena e o direito do sujeito de ter o status de full partner, o que pode significar a criação de categorias de cidadãos. Para evitar tais hierarquizações, a Autora sugere combinar as questões de redistribuição e reconhecimento, duas dimensões da justiça social, "the two dimensions are interimbricated and interact causally with each other", como propõe o modelo do full partner (189).

${ }^{48} \mathrm{O}$ conceito de risco é uma importante ferramenta no campo da saúde pública, entretanto, de acordo com Seara LN, "o estigma trazido pela aids aderiu aos discursos sobre grupos de risco, acrescentando ao conceito epidemiológico um peso valorativo negativo", uma dupla função, pois ao mesmo tempo em que discriminava também justificava a importância de traçar estratégias específicas pra essas populações (187).

49 A ideia de "peste gay" ou "câncer gay" foi seguida pela ideia da "doença dos quatro Hs", em razão dos grupos mais comumente afetados: homossexuais, hemofílicos, haitianos e heroinômanos (190).
} 
infecção pelo HIV ocorreria somente nestes grupos sociais que deveriam, portanto, ser isolados para proteção das demais pessoas da sociedade. Contudo, a história da doença provou o contrário, mas a consequência deste entendimento resultou em estratégias discriminatórias de prevenção que posteriormente mostraram-se inadequadas e insuficientes para o enfrentamento ao HIV/AIDS.

A categoria "grupo de risco" foi substituída pela categoria "comportamento de risco" no intuito de ampliar o entendimento de que qualquer pessoa poderia ser afetada pela aids; desta forma passou-se a identificar o conceito "comportamento de risco" com as práticas individuais em vez de características relacionadas a um grupo específico. Mesmo considerando o progresso deste conceito no que se refere à tentativa de redução da discriminação e ampliação de medidas de prevenção para toda a população, mantevese a ideia de culpabilização do indivíduo, na medida em que a responsabilidade pela prevenção e/ou infecção pelo HIV/AIDS dependeria exclusivamente da capacidade cognitiva e comportamental do sujeito.

Na década de 90, questionou-se a ideia do "comportamento de risco", quando Jonathan Mann e sua equipe (83) introduziram o conceito de vulnerabilidade para abarcar os determinantes estruturais presentes na dinâmica da epidemia; entendendo este quadro conceitual como a chance de exposição das pessoas ao adoecimento, como resultante de um conjunto de aspectos tanto individuais quanto coletivos e contextuais que acarretam maior suscetibilidade à infecção e o adoecimento, conforme Ayres (84). Neste contexto, os comportamentos associados a maior vulnerabilidade para a infecção pelo HIV não são apreendidos como uma consequência da ação voluntária, mas estão relacionados a condições objetivas do ambiente e a condições culturais e sociais, conforme Meyer, et. al (85).

Este conceito traz como perspectiva a possibilidade de ampliar os horizontes de compreensão dos modelos de intervenção no campo da saúde pública, além de incorporar um conjunto de conhecimentos e práticas de caráter humanístico aos repertórios da saúde, o que seria impossível a partir do uso exclusivo de instrumentos restritos ao campo da epidemiologia, segundo Ayres (86).

No plano individual, a avaliação das vulnerabilidades abarca os comportamentos singulares que aumentam a chance de infecção pelo vírus HIV, como por exemplo, o 
grau de compreensão sobre as formas de infecção. No plano social, a avaliação das vulnerabilidades deve levar em conta os fatores culturais, políticos e sociais que influenciam no maior ou menor grau de vulnerabilidade que afetam o sujeito, tais como a exposição a situações de violência e exclusão. No plano institucional ou programático, avalia-se principalmente o compromisso das autoridades locais com o enfrentamento do problema da aids, as ações efetivamente propostas por tais autoridades, a coalizão interinstitucional e intersetorial (saúde, educação, bem-estar social, trabalho, direitos humanos, etc.) para atuação específica, dentre outros atores, como programas educacionais que abordem a transfobia e a violência de gênero.

Portanto, considerar os diferentes contextos de vulnerabilidades para o desenvolvimento de políticas públicas é uma medida importante para o avanço da justiça, da equidade e da ética nos campos prático e teórico. Além disso, deve-se considerar a dimensão continental do Brasil e suas disparidades econômicas, sociais e demográficas, isto é, os vários "Brasis" que imprimem características diferenciadas na forma como o HIV se propaga entre a população, na possibilidade de acesso à rede de saúde, na adesão aos medicamentos e até mesmo para o risco de óbito em decorrência da aids, conforme Parker, R e Camargo Jr (87).

Ressalte-se que as diferentes epidemias de HIV no mundo têm em comum o fato de que a comunidade LGBT encontra-se "em risco" "50, não apenas pelo maior risco de infecção pelo HIV, mas também pelo "risco à violência, discriminação", conforme Tulloch \& Lupton (88). Deste modo, ainda que se considerem os relevantes progressos do conhecimento e da técnica científica para controlar o vírus e sua interação no organismo, e mesmo com o avanço das medicações e da compreensão técnica, não se deve esvaziar a necessidade de ações preventivas que considerem os diversos contextos de vulnerabilidades de cada grupo populacional, uma vez que a exposição das pessoas ao vírus não é homogênea e a possibilidade de mudanças práticas no campo da prevenção não depende somente da vontade individual de cada um, mas também dos contextos de vida aos quais as pessoas estão inseridas. Concordando com Ayres (89), as intervenções estruturais, a mobilização social, a cidadania, o ativismo político, a ação

\footnotetext{
${ }^{50}$ Neste contexto, "o risco" é problematizado como uma medida calculável, um aspecto de incerteza imposta a determinados grupos, como o grupo de travestis, perspectiva diferente daquela que marcou negativamente os primeiros anos da epidemia de Aids.
} 
jurídica $^{51}$, a defesa dos Direitos Humanos, são partes indissociáveis das ações de prevenção e cuidado, tanto no plano macro, para superar obstáculos econômicos, culturais e políticos, quanto no plano individual, afim de que o sujeito possa fazer suas escolhas baseadas em conhecimento, autonomia e liberdade.

Neste estudo as ações de prevenção definem-se como estratégias orientadas para evitar a infecção pelo HIV, bem como para reduzir sua incidência e prevalência entre a população de travestis. O termo prevenção é utilizado no sentido de chegar antes, preparar, prevenir, evitar o dano, mal, impedir que se realize.

Segundo Leavell e Clarrck (90), para a realização de intervenções preventivas é necessário que a ação antecipada esteja baseada no conhecimento da história natural para que se torne o mais difícil possivel o progresso posterior da doença. O discurso preventivo do HIV/AIDS é baseado no conhecimento epidemiológico que se aproxima do conceito de risco, mencionado anteriormente e que se caracteriza pela probabilidade de ocorrência de um evento desfavorável e engloba uma variedade de medidas probabilísticas que tem como base dados estatísticos.

Sem perder de vista a importância do conceito de risco para o controle do HIV/Aids assume-se necessário, além deste conceito, a utilização do conceito de vulnerabilidade, explicitado ao longo deste trabalho, uma vez que de acordo com Ayres, J.R.C.M (91) e Czeresnia D, Freitas CM (92) o risco é um conceito útil pela sua capacidade de gerar e testar hipóteses consistentes e relevantes para o conhecimento teórico da Aids, mas limitado, já que a análise de risco, assim como o conhecimento epidemiológico é construído com base em uma suposta verdade cientifica 'que lhe garantem manuseio formal e matemático de grande precisão', entretanto, mesmo com o potencial explicativo/operativo, este conceito tem como limite a incapacidade de representar a realidade de maneira sensível, sendo que a subjetividade, a significação, a interação, a dinamicidade são fundamentais para quem pensa a prevenção. Desta maneira olhar para a epidemia exclusivamente na perspectiva epidemiológico resulta no afastamento de aspectos importantes da realidade que não conseguem ser capturados por este modelo. Em resumo, as intervenções e projetos de prevenção discutidos nesta dissertação estruturam mediante o conhecimento de informac $\square$ ão cientificas ligadas a

\footnotetext{
${ }^{51}$ Para maiores informações sobre as questões envolvendo judicialização e conseqüências jurídicas da epidemia da aids, ver: Seara LN, 2011 (187).
} 
epidemiologia e seus estudos sobre risco, ao conceito de vulnerabilidade discutidas anteriormente e a noção de promoção em saúde, tomando a promoção em saúde a partir da perspectiva progressista definida pela OMS que enfatiza aspectos como a intersetorialidade na elaboração das politicas públicas, empoderamento, participação social, equidade, ações multi-estratégicas e sustentabilidade (93).

Atualmente o alcance de resultados efetivos no combate ao HIV/AIDS perpassa pelo que atualmente é denominado "prevenção combinada", na qual se estabelece a cooperação entre atores diversos, como os governos estaduais e municipais, OSC, instituições de pesquisa, bem como no envolvimento do setor privado. A estratégia combina, de um lado, as usuais práticas de prevenção clássica, tais como a disponibilização dos preservativos masculino e feminino, gel lubrificante, insumos para pessoas que usam drogas e testagem; e de outro lado, intervenções biomédicas como a profilaxia pré (PrEP) e pós-exposição $(\mathrm{PeP})$ e tratamento como prevenção (Tarv). A profilaxia pós exposição, é uma medida de prevenção da infecção pelo HIV que consiste no uso combinado de novas drogas antirretrovirais (ARV), pelas pessoas que eventualmente tenham entrado em contato com o vírus recentemente através de sexo sem camisinha. Esses medicamentos devem ser tomados por 28 dias sem interrupções para impedir a infecção pelo vírus, sempre com orientação médica, sua eficácia depende ainda do início do tratamento em até 72 horas depois da exposição ao vírus, por isso é considerado de urgência, já que a administração dos medicamentos deve começar o mais cedo possível. A profilaxia Pré Exposição (PrEP) consiste no uso combinado de diversas formas de antirretrovirais (ARV), antes da exposição ao HIV. Outra importante estratégia no cardápio da prevenção combinada é manter as pessoas infectadas pelo vírus HIV com carga viral abaixo dos níveis de detecção e sem apresentar outras DST, com isso a cadeia de transmissão do vírus HIV é reduzida ${ }^{52}$.

A promoção do tratamento como estratégia de prevenção aliada à promoção do diagnóstico e tratamento oportuno constituem ferramentas para o fim de novas infecções pelo HIV, mas, da mesma forma que demais estratégias apresentadas neste estudo, devem cuidar para não homogeneizar as ações preventivas e regular as diferenças partir de um modelo de sexualidade hegemônico e binária de gênero.

\footnotetext{
${ }^{52}$ Para mais informações consultar: Coordenação Estadual de DST, HIV, Aids de São Paulo. [Citado em 2014 maio 12]. Disponível em: http://www3.crt.saude.sp.gov.br/profilaxia/hotsite e http://www.cdc.gov/hiv/basics/prep.htm.
} 
Vale notar que no caso das estratégias de prevenção voltadas para a população de travestis, a invisibilidade de tal população e a responsabilização individual pelo agravo são bastante comuns, a centralidade em ações preventivas de cunho comportamental e individualizada ainda se sobressaem e frequentemente conseguem relativizar os fatores sociais, culturais e políticos geradores de desigualdades e exclusão social, contextos que estão na base da suscetibilidade à infecção pelo vírus HIV, conforme Mann, Tarantola e Netter (94).

Pelas razões acima descritas, nesse trabalho também se recorre ao conceito de vulnerabilidade descrito na DUBDH, combinado àquele estabelecido pelo campo da aids, como uma das categorias analíticas para abordar os problemas relacionados às políticas de prevenção do HIV/AIDS entre travestis, por entender que a vulnerabilidade é uma importante lente de aumento para a definição de políticas justas e proteção social, para tanto deve ser analisada em contextos concretos, definidos pelos diferentes sujeitos sociais, conforme demonstrado por autores como Mann e Tarantola (94), Richard Parker (95) e Ricardo Ayres (96), o qual esclarece ainda:

O conceito de vulnerabilidade visa a não distinção daquele que tem alguma chance de se expor as DST/AIDS, mas sim o fornecimento de elementos para avaliar objetivamente as diferentes chances que todo e qualquer indivíduo tem de se infectar, dado o conjunto formado por certas características individuais, sociais e institucionais de seu cotidiano julgadas relevantes para maior exposição ou menor chance de proteção diante do problema (97).

Desta forma, vale questionar porque os esforços despendidos pelo governo têm se mostrado insuficientes para estimular uma resposta efetiva na prevenção ao HIV, prova disso é que a epidemia entre travestis continua a se alastrar e expandir seu alcance, diferentemente do que vem ocorrendo com outros grupos sociais cuja epidemia está estabilizada ou em decréscimo, conforme os dados apresentados no decorrer deste trabalho.

\subsection{AS VULNERABILIDADES VISTAS DE PERTO}

No ano de 2010, durante uma oficina ${ }^{53}$ realizada com representantes do movimento de travestis e transexuais, me chamou a atenção a fala de uma travesti sobre a dificuldade

\footnotetext{
${ }^{53}$ A oficina realizada em Brasília pelo Ministério da Saúde, onde participei como facilitadora, contou com a participação de travestis e transexuais de diversas regiões do Brasil e teve como objetivo o
} 
de sair de casa para ir a um serviço de saúde pegar camisinha, por exemplo, pois além do receio de ser discriminada nestes espaços havia a dificuldade de caminhar pelas ruas durante o dia; segundo ela, sair durante o dia lhe exigia muita "paciência" e "boa vontade" e, mesmo gostando em certas ocasiões de chamar a atenção, noutras, só desejava caminhar livremente sem ser importunada por gritos, assobios, risos e ameaças. Conforme se pode observar na fala da travesti e ativista Janaina Lima ${ }^{54}$, as vulnerabilidades para o HIV/AIDS estão intrinsecamente ligadas com o respeito, a dignidade humana, os direitos humanos e as liberdades fundamentais, bem como com a não discriminação e não estigmatização, conforme descrito no artigo 11 da DUBDH, pelo qual nenhum indivíduo ou grupo deve ser discriminado ou estigmatizado por qualquer razão, o que constitui violações à dignidade humana, aos direitos humanos e liberdades fundamentais. Ainda conforme a Ativista:

Claro que a prevenção também precisa fazer parte da minha vida, preciso sim usar camisinha, mas não preciso só usar camisinha, porque para chegar até aqui (...)[referindo-se ao local da entrevista - grife-se], o constrangimento que querendo ou não, eu passo, entendeu? Minha cabeça vai a mil, fico doida, minha saúde mental vai... entendeu? E aí eu tenho que me manter ou abaixar a cabeça e falar: 'não', 'desculpa', 'por favor'; ou tenho que brigar e ficar louca... não há saúde mental que aguente (Janaina Lima ${ }^{55}$ ).

A dificuldade apontada pela referida Ativista faz parte do cotidiano da maior parte das travestis e compõe a lista de violações de direitos que diminuem a auto-estima e a capacidade de cuidar da própria saúde. Neste sentido, a maneira como se estruturam a maior parte dos serviços de saúde, funcionando no chamado horário comercial de segunda à sexta-feira das oito às dezoito horas, bem como a forma como as travestis são percebidas, inibem a presença das mesmas nestes espaços. Como exemplo, a fala de outra ativista chamada Fernanda Benvenuti:

A situação das travestis difere das demais por agregar dois problemas: o primeiro, comum a todas as pessoas que trabalham no período noturno, é ter de que estar às oito horas da manhã, acordada e em pé, para pegar uma ficha de atendimento

desenvolvimento da Campanha: "Sou travesti: tenho direito de ser quem eu sou". [Citado em 2014 Nov. 10] Disponível em: www.aids.gov.br/travesti.

${ }^{54}$ Depoimento dado pela travesti e ativista Janaina Lima, pedagoga, profissional do sexo e militante do grupo Identidade Ativista na Luta por Direitos das Pessoas Trans (191).

55 Idem 54. 
e esperar horas até ser atendida. $\mathrm{O}$ segundo, reservado às travestis e transexuais, é 'encarar a síndrome do cotovelo (98).

Segundo Fernanda Benvenuti, que além de ativista do movimento de travestis e transexuais, também trabalha como técnica em enfermagem na Paraíba, basta uma travesti chegar num serviço de saúde para que todos comecem a se acotovelar, apontando entre si a chegada de uma "estranha". Por isto a ativista considera necessário que se faça um trabalho de humanização com todos os profissionais que trabalham nos serviços de saúde, a começar pelo segurança que atende na entrada do posto:

Eles precisam aprender a lidar com a gente. Em um serviço público, que é um dever do Estado, você recebe a mesma discriminação da rua. As pessoas enxergam as travestis como se fossem uma mazela social, mas nós não somos, nós pagamos impostos e ajudamos a construir esta sociedade (99).

A "síndrome do cotovelo" descrita, vinculada ao constrangimento de ser chamada pelo nome de registro e não pelo nome social, podem ser compreendidas como parte do arsenal de sistemas simbólicos refinados de preconceito, estigma e desvalorização dos sujeitos, além de denunciar o despreparo de profissionais de saúde no que se refere ao atendimento desta população. Tais fatores alargam as barreiras de acesso e vinculação aos serviços, conforme apontado pelo então Ministro da Saúde José Temporão, em 2010:

As travestis sofrem agressões nos espaços públicos, a exemplo do que ocorre quando são chamadas em público, por profissionais de saúde, por seus nomes de registro e não por seu nome social. Muitas passam a evitar o serviço de saúde (100).

As iniquidades evidenciadas acima nos remetem às discussões travadas há dez anos, durante a primeira campanha nacional para travestis realizada em 2004 pelo Programa Nacional de DST, HIV e Aids, em parceria com o movimento de travestis. Na época já se assinalava que o respeito é mais do que uma bandeira a ser levantada, é um direito dessa população que vive em situação de marginalidade e estigma, especialmente frente à epidemia de aids. Com o slogan "Travesti e respeito: já está na hora dos dois serem vistos juntos. Em casa. Na boate. Na escola. No trabalho. Na vida", a campanha foi lançada no dia 29 de janeiro, evidenciando cidadãs que lutam diariamente pelo direito ao trabalho, à educação, ao bom atendimento no serviço de saúde, pelo direito de "ser quem escolheram". As violações de direitos assinaladas na campanha tornaram-se ainda 
mais evidentes quando se registrou, após quatro anos do seu lançamento, que a maioria das 28 travestis que participaram da atividade estava morta em decorrência da aids, da violência ou pela exclusão social. Confira-se imagem abaixo:

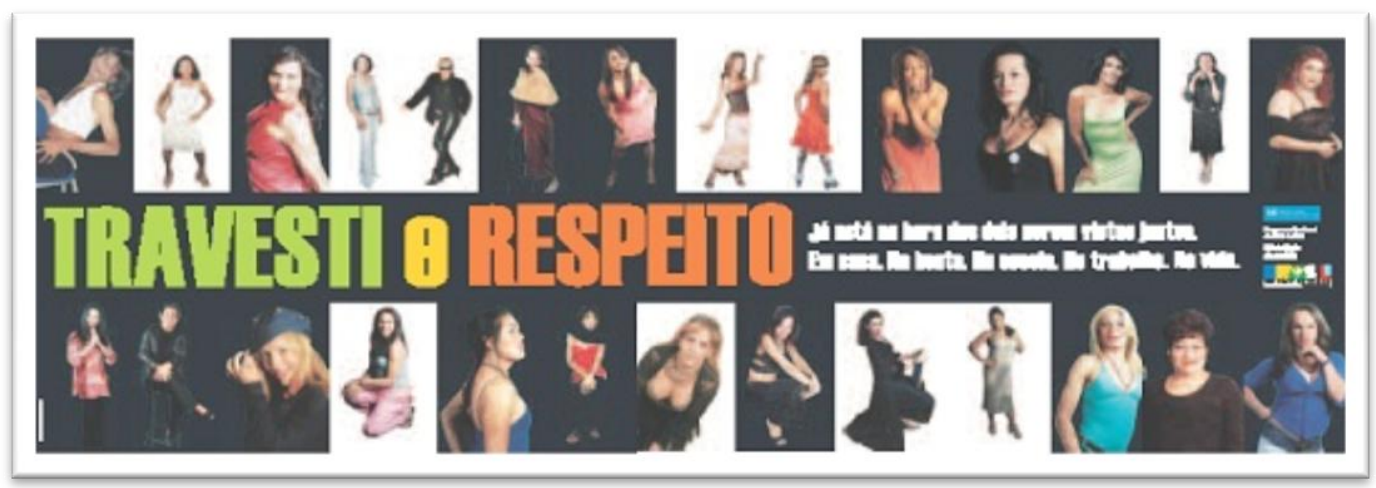

Figura 01: cartaz referente a primeira campanha: "Travesti e Respeito"

Seis anos depois da primeira campanha, o Departamento de DST/HIV/AIDS e Hepatites Virais lançou, no dia 29 de janeiro de 2010, em comemoração ao "Dia da Visibilidade Trans", sou", com ênfase na promoção dos direitos humanos e prevenção da aids, além de enfretamento da transfobia ${ }^{57}$. O conceito da campanha seguiu a mesma lógica da anterior, sendo construída com a participação de representantes do movimento social, para quem a campanha deveria enfatizar a chamada "visibilidade positiva de travestis" ${ }^{, 58}$, conforme aponta a fala da travesti Karen de Oliveira, representante da ONG

\footnotetext{
${ }^{56}$ Vale notar que a partir da primeira campanha, de 2004, o dia 29 de janeiro passou a ser reconhecido pela população LGBT como o "Dia da Visibilidade Trans". Inicialmente a data ficou conhecida unicamente como "Dia da Visibilidade de Travestis", mas com o maior engajamento e organização do movimento de homens e mulheres transexuais, foi deliberado pelos movimentos que se estendiam as atenções para todas as pessoas "Trans", desde então a data é celebrada e a inserção social e o protagonismo das travestis voltam a ser debatidos.

${ }^{57}$ Para maiores conhecimentos e informações dos produtos da campanha [citado em 2014 nov. 09] Disponível em http://www.aids.gov.br/travestis e http://www.aids.gov.br/comunicacao-em-saude.

${ }^{58} \mathrm{O}$ termo "visibilidade positiva" compõe o objetivo 03 - "Promover a visibilidade positiva das travestis junto às instâncias governamentais, aos serviços de saúde e à população em geral", constante na "Agenda afirmativa de travestis" do Plano Nacional de Enfrentamento da Epidemia de Aids e das DST entre gays, HSH e travestis; 2008.
} 
Beija-Flor e diretora suplente da Associação Brasileira de Gays, Lésbicas, Travestis e Transexuais $(\mathrm{ABGLT})^{59}$ :

\begin{abstract}
A importância deste dia é valiosa, [referindo-se ao dia de lançamento da Campanha- grife-se] pois é mais uma barreira que derrubamos, e mostramos que existimos além das ruas e dos becos. Mostramos que somos pessoas com responsabilidade e direitos, temos família e uma vida social, mesmo que excluídas (101).
\end{abstract}

Ambas as campanhas, conforme analisado inicialmente por Pelúcio (102), utilizaram linguagem e jargões próprios ao segmento de pessoas trans, de modo a minimizar a indiferença das travestis em relação às mensagens e serviços comumente oferecidos pela área de saúde. Contudo, a experiência acumulada trabalhando com temas relacionados à prevenção do HIV/AIDS nos mostra que não basta que o conteúdo seja aprovado pelas partes interessadas para que as mensagens cheguem ao seu destino, existe um longo percurso que vai da burocratização (comum a todos os processos governamentais) à resistência em transmitir mensagens direcionadas a esta população. A saber, após a finalização e aprovação dos materiais pelas áreas de comunicação do Ministério da Saúde, há dispensação dos mesmos para as 27 Unidades Federativas, cujo fluxo de distribuição é estabelecido com base na demanda e situação de cada local. No caso dos materiais citados, a distribuição foi feita para as OSC de lésbicas, gays, bissexuais, travestis e transexuais, Secretarias Estaduais de Saúde e Coordenações Estaduais e Municipais de DST/HIV/AIDS, para que cada instituição pudesse redistribuir localmente. Embora o conteúdo das campanhas procurasse sensibilizar gestores e profissionais de saúde para a observância da equidade em relação a população trans, a baixa adesão e divulgação dos materiais nos serviços de saúde locais têm sido recorrentemente apontada nos ENTLAIDS, em encontros e seminários regionais pelas ativistas do Movimento Trans.

Um exemplo ocorreu na II Mostra Nacional de Experiências em Gestão Estratégica e Participativa no $\mathrm{SUS}^{60}$ (II EXPOGEP), durante o debate ${ }^{61}$ realizado no dia 06/02/2014

\footnotetext{
${ }^{59}$ A Associação Brasileira de Lésbicas, Gays, Bissexuais, Travestis e Transexuais (ABGLT) foi criada em 31/01/1995 e atualmente conta com 308 organizações afiliadas, sendo a maior rede LGBT na América Latina. [citado em 2014 out. 18]. Disponível em: http://www.abglt.org.br/port/index.php.

${ }^{60}$ A II EXPOGEP ocorreu em Brasília entre os dias 02 e 06 de fevereiro de 2014, com vistas a dar visibilidade e reconhecimento às experiências exitosas em gestão estratégica e participativa
} 
na Tenda Paulo Freire, sobre política nacional LGBT, representantes do movimento LGBT observaram o quanto é incomum encontrar peças publicitárias dirigidas à comunidade de pessoas trans nos serviços de saúde, como os cartazes feitos em 2012 pelo Ministério da Saúde sobre o direito ao uso do nome social; conforme as ativistas, os cartazes muitas vezes ficam "guardados" em armários ou "esquecidos" nas repartições públicas, ou pior, são utilizados arbitrariamente como material de consumo, substituindo o flip-chart.

Abaixo seguem imagens dos cartazes referentes à campanha "Sou travesti. Tenho direito de ser quem eu sou", de 2010:

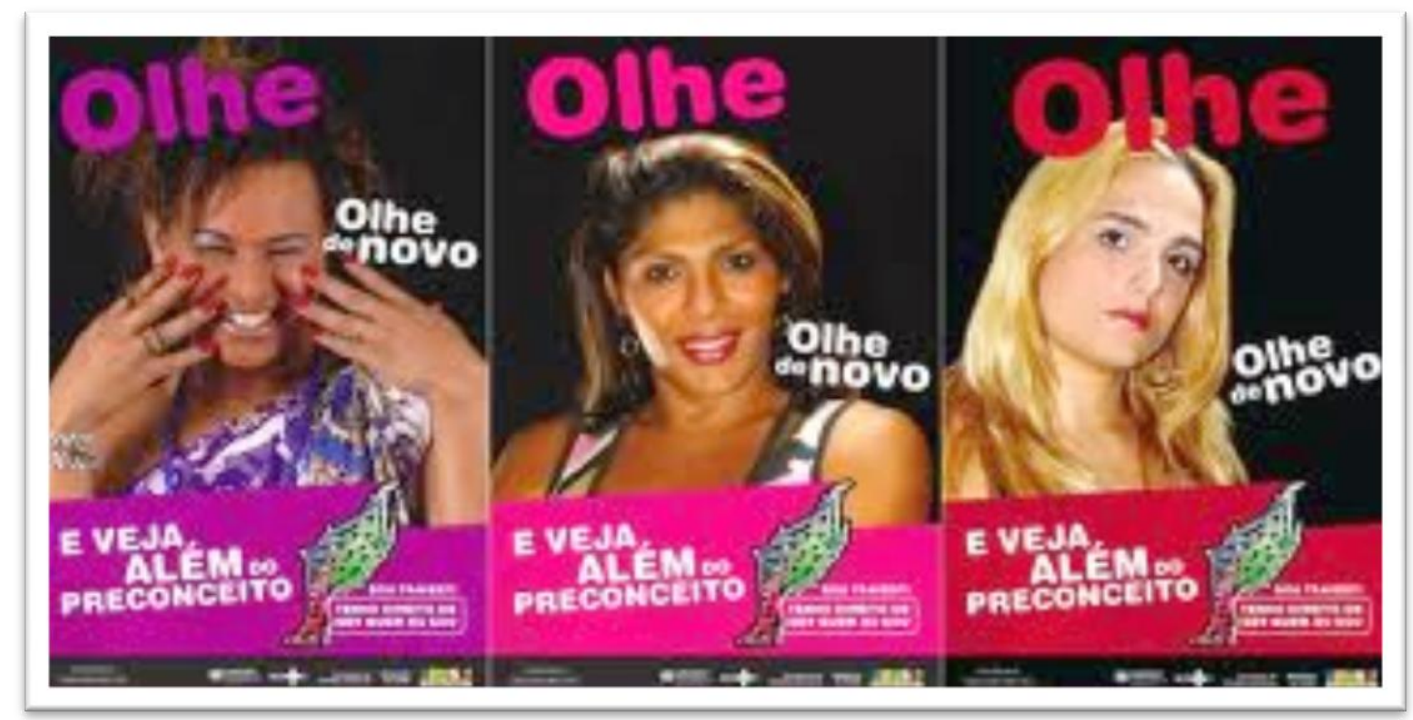

implementadas no âmbito do SUS ao longo dos seus 25 anos, marcando também os 60 anos do Ministério da Saúde (MS) e os 10 anos de Secretaria de Gestão Estratégica e Participativa (SGEP). Maiores informações [citado em 2014 Out. 15]. Disponível em: http://www.conasems.org.br/index.php/comunicacao/noticias-principais/3181-ii-expogep-resultado-daselecao-e-inscricoes.

${ }^{61} \mathrm{O}$ debate intitulado "Vídeo da Oficina de Lésbicas e Bissexuais", no qual participei como facilitadora pelo Ministério da Saúde contou com um público de aproximadamente 50 pessoas, entre gestores, acadêmicos, trabalhadores da saúde e militantes sociais LGBT. 


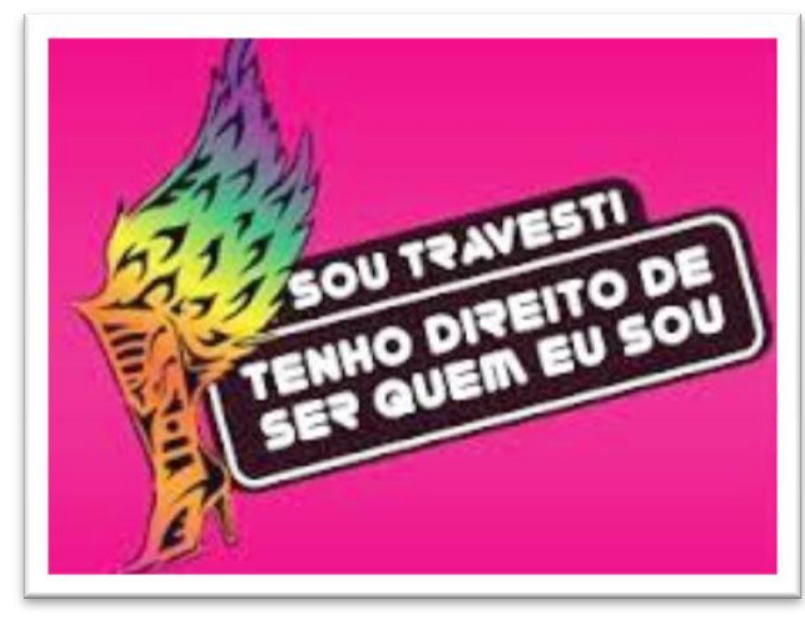

Figura 02: cartazes referentes à campanha: “Sou travesti. Tenho direito de ser quem eu sou”, de 2010

Desta forma, é importante notar que transcorrido seis anos entre uma campanha e outra, o tema central "dignidade e respeito" se mantém atual, expondo a tensão entre interpretações e interesses divergentes por parte dos operadores das políticas públicas, acerca do que está preconizado pelo SUS.

Segundo Paiva (103), nos serviços de saúde tanto existem profissionais que se identificam com valores conservadores nos quais foram socializados, como no caso daqueles que se negam a colar cartazes sobre o direito à dignidade e o respeito de travestis, quanto existem profissionais que se identificam com valores mais compreensíveis e respeitosos à diversidade, entretanto, mesmo estes, nem sempre estão abertos para discutir fatores que influenciam na prevenção; por exemplo, em geral a conduta sexual relacionada ao não uso do preservativo é entendida de maneira simplista, como um ato irresponsável no qual o culpado, em última instância, é o sujeito que decide não usar. Ao desconsiderar as diferentes motivações que levam o sujeito a não fazer uso do preservativo cria-se uma barreira na comunicação e na possibilidade de identificar fatores de proteção à infecção pelo HIV/AIDS, “como se o sexo seguro dependesse sempre da vontade e da razão informada, acusando os que não absorvem adequadamente ('desconsideram') os guias para a proteção do sexo”.

Outro fator que mereceu destaque entre as preocupações das travestis, no processo de desenvolvimento da segunda campanha, foi o direito ao sigilo durante as consultas médicas. Segundo os relatos, muitos profissionais de saúde se recusam a atendê-las sozinhos nos consultórios e/ou procuram manter as portas abertas durante os 
atendimentos, o que impacta negativamente na busca pelos serviços e na adesão ao tratamento, uma vez que não se sentem à vontade e passam a ter medo que terceiros saibam e posteriormente revelem sua eventual soropositividade.

Para elas, o fato de não serem atendidas individualmente ocorre em razão do preconceito e pelo temor dos funcionários de virarem alvo de pilhérias por parte dos colegas. Vale notar que embora o temor de ser identificada como portadora do HIV seja menor do que no início da epidemia, entre as travestis a aids está longe de ser um problema superado, ao contrário, conforme alerta Teixeira (104), para as travestis mesmo que o temor do diagnóstico positivo seja muitas vezes silenciado, ou até mesmo negado, a realidade é outra; como um "tema tabu", a aids torna-se impronunciável e ainda é encarada por muitas travestis como uma "tragédia anunciada". Nessa esteira, Pelúcio apresenta:

Talvez por isso Danuza, que vive com aids desde de 1997, não tenha se surpreendido quando obteve o resultado de seu teste, respondendo em tom quase resignado à minha pergunta sobre a sua reação diante do exame positivo: 'A gente sempre espera, né? Com aquela vida que a gente leva, a gente espera tudo, né?' O fatalismo que soa dessa declaração permeia muitas falas das travestis que participaram desta pesquisa (105).

Desta maneira, é importante ressaltar o quanto a percepção sobre o modelo de atendimento nos serviços de saúde pode significar deixar de fazer exames, ir as consultas e/ou pegar os medicamentos. Neste sentido, o relato da ativista Fernanda Benvenutty ${ }^{62}$ expressa o longo caminho a percorrer para o enfrentamento do HIV/AIDS e das barreiras individuais, sociais e programáticas que impedem o acesso a saúde integral e equânime desta população:

Dentro do SUS vemos profissionais que quando se deparam com uma travesti ficam jogando uns para os outros - 'Ah, não, isso aqui é para fulano' - E onde é que nós vamos esbarrar? Qual é o profissional que vai cuidar da travesti? Simplesmente nos mandam para os profissionais da aids, porque até hoje somos vistas como 'grupo de risco', como pessoas vivenciando ainda aquele processo passado de que a aids era exclusividade dos homossexuais. (Fernanda Benvenutty ${ }^{63}$ )

\footnotetext{
${ }^{62}$ Depoimento dado pela travesti e ativista Fernanda Benvenutty, Técnica em enfermagem, conselheira nacional de saúde, fundadora, ex-presidente e atual relações públicas da Associação de Travestis da Paraíba - ABRAPA. (191).

63 . Idem 62.
} 
A situação acima relatada contraria o que é preconizado pelo Ministério da Saúde, quando indica que a postura do profissional é essencial para a adesão e tratamento. Segundo o "Manual de Adesão ao Tratamento para Pessoas Vivendo com HIV e Aids" (106) a atenção e o respeito profissional podem garantir ao paciente o sentimento de vínculo e suporte fundamentais para o processo de adesão. Vale lembrar que mesmo em caso de pacientes com resultado negativo para o HIV, o momento da consulta é uma oportunidade preciosa para que os profissionais identifiquem os fatores que podem impactar na redução de risco ao HIV.

A despeito das questões tratadas acima, estudos realizados por Barreda e Isnardi (107) relatam que na América Latina pessoas trans consideram hospitais e serviços de saúde indiferentes e/ou discriminatórios, portanto tais serviços são acessados apenas em casos de extrema necessidade; outro problema, já mencionado anteriormente e detectado pelo referido estudo, aponta que na Argentina, assim como no Brasil, equipes médicas frequentemente não reconhecem a identidade das travestis e costumeiramente referemse a elas pelo nome masculino. Na prática, tais experiências traduzem um conflito ético entre a concepção "filosófica" a respeito do que sejam as práticas de promoção, proteção e recuperação da saúde e o significado das práticas discriminatórias que vão interferir diretamente no direito à saúde e no bem estar dos sujeitos pertencentes a determinados grupos sociais.

Ainda em relação ao atendimento em saúde, o artigo "La primera consulta con una trans" (09) considera um agravante para a baixa qualificação do atendimento a travestis a existência de poucos estudos que contemplem esta população nas universidades, de modo que os profissionais da área médica precisam aprender no cotidiano como lidar com tais pacientes. Muitas travestis têm a anatomia e fisiologia alteradas por diferentes tecnologias como o uso de hormônios, silicones e outras substâncias que nem sempre correspondem às normas médico legais. Muitas vezes tais pacientes chegam à consulta em situações de urgência e para muitos profissionais é difícil decidir como atuar quando não se sabe ao certo como melhor proceder para amenizar os efeitos adversos de substâncias utilizadas para modificações corpóreas.

$\mathrm{O}$ artigo cita o exemplo das intervenções caseiras relacionadas aos efeitos secundários dos hormônios e do silicone industrial, utilizado para modificação de partes específicas 
do corpo, tais como nádegas, mamas, pernas e lábios. Estudos ${ }^{64}$ têm demonstrado que entre a população trans é frequente o emprego de autoadministração de silicone líquido por pessoas não qualificadas, além das péssimas condições de higiene, não assepsia e antissepsia adequada dos matérias utilizados em tais procedimentos, o que aumentam as chances de contaminação bacteriana ou por fungos (Garrafalo, et. al). (108) Já os chamados hormônios sexuais têm efeitos feminilizantes (estrogênio) ou masculinizantes (androgênios) e, apesar de seus efeitos trazerem benefícios em relação a transformações corporais desejadas, seu uso não está isento de riscos e efeitos colaterais para a saúde, sobretudo quando utilizados sem controle clínico, tais como doenças tromboembólicas, disfunção hepática, enxaquecas, hipertensão, retenção de líquidos, entre outras. Por esta razão, o uso de hormônios demanda acompanhamento médico para prescrição e monitoramento.

Outra questão a ser considerada é a relação médico/paciente, pois as ocorrências indesejáveis relacionadas ao uso destas substâncias precisam necessariamente de informações fornecidas pelas próprias pacientes. Tais informações não são facilmente obtidas, uma vez que a relação médico/paciente está permeada por medos e incertezas de ambos os lados. De um modo geral, sabe-se que a percepção do paciente sobre seu agravo e/ou necessidades de cuidado nem sempre se adequam ao modelo clínico, visto que são percepções muito individualizadas e, embora não se espere que médicos ajam como psicólogos ou psicanalistas, seria desejável que, para além dos suportes técnicos sobre o diagnóstico, pudessem reconhecer a realidade do sujeito a sua frente, de modo que a comunicação médico/paciente pudesse se tornar mais empática e adequada à compreensão do problema e ao entendimento do paciente sobre o diagnóstico e formas de cuidado (Caprara, A; Rodrigues J) (109).

Sobre este tema, de acordo com Leone (09), o fato de travestis e transexuais terem, em grande parte, experienciado um processo de socialização bastante peculiar, sendo obrigadas a mentir e/ou manipular para evitar o castigo e constrangimentos, faz com que se sintam particularmente afetadas diante de situações que remetam as violências vivenciadas anteriormente. Portanto não é difícil calcular que o uso do autoritarismo ou

\footnotetext{
${ }^{64}$ Para maiores informações consultar: Arilha M; Lapa TS, Pisaneschi TC, 2010 (191). Peres WS, 2005 (192).; Moscheta MS, 2011 (193).
} 
o tom crítico por parte de profissionais de saúde poderá ocasionar afastamento dos serviços e/ou obtenção de informações falsas e/ou parciais.

O autor também reflete sobre as situações onde profissionais de saúde, movidos por curiosidade, solicitam informações desnecessárias, invadem a intimidade da paciente e/ou observam seu corpo como se fosse um "prodígio"; nestes casos, algumas pessoas trans narram a dor que provocam tais atitudes e a percepção da ironia e hostilidade por parte desses profissionais, o resultado destas situações é o estabelecimento de uma relação de defesa que se manifesta através de comportamentos hostis, desconcertantes ou mesmo agressivos.

As questões relatadas acima ferem o princípio de dignidade humana trazido pela DUBDH, a qual estabelece que a dignidade deve ser tratada como uma unidade fundamental a todos os seres humanos, respeitando sua singularidade e diversidade. Assim, conforme Garrafa e Prado (110), os dilemas detectados no âmbito da saúde pública e da bioética devem ser enfrentados com mais objetividade, os profissionais da área da saúde e os bioeticistas devem estar atentos para o que os Autores nomeiam como o "esvaziamento e despolitização dos conflitos morais que exclui o espaço para a indignação" e aumentam a chance de exclusão das travestis dos serviços de saúde. Ainda segundo os Autores, a ética deve ser mais do que um mecanismo de leitura e interpretação dos conflitos desprovida de proposta interventiva. Portanto, preservar a intimidade da paciente implica em ter disponibilidade para orientá-las sem juízo de valores, ou seja, garantindo os direitos sexuais já reconhecidos em leis nacionais e documentos internacionais. Para tanto, é necessário ter disponibilidade para repensar valores estabelecidos e normatizados cotidianamente, o que segundo Amuchástegui (111), se constitui como um grande desafio, uma vez que as políticas públicas no campo da saúde e dos direitos sexuais e reprodutivos seguem padrões heteronormativos que se traduzem numa associação limitada entre a saúde sexual e a procriação dentro dos marcos da família nuclear "pai, mãe e filhos".

Outra barreira para a promoção e prevenção do HIV/AIDS entre as pessoas trans é o acesso aos insumos para tanto, preservativos e gel lubrificante. No "III Seminário nacional de direitos humanos e HIV/AIDS",65, cujo mote era " $O$ direito à saúde no

\footnotetext{
${ }^{65}$ O III Seminário Nacional de Direitos Humanos e HIV/Aids ocorreu conjuntamente com o I Seminário Nacional de Hepatites Virais, entre os dias 13 a 15 de junho de 2012. [Citado em 2014 nov. 13]
} 
cenário contemporâneo dos direitos humanos: aids e hepatites virais", ocorrido em Brasília, foi identificada a dificuldade de acesso aos preservativos e ao gel lubrificante em muitos municípios brasileiros ${ }^{66}$. Embora o Ministério da Saúde preconize $^{67}$ a necessidade de se priorizar e garantir acessibilidade aos insumos para esta população, diferentes representantes do movimento LGBT relataram a dificuldade de acesso aos insumos de prevenção.

Segundo tais relatos, alguns profissionais de saúde desconsideram o princípio da equidade e sob o argumento de não "privilegiar ninguém”, restringem o número destes insumos, fornecendo-os em igual quantidade para todos os usuários dos serviços de saúde, com isso acreditam, inadvertidamente, evitar o desperdício e a venda ilegal de preservativos e gel lubrificante. Daí se perde a oportunidade de acolhimento das travestis e do eventual estabelecimento de vínculos que possibilitem responder a esta importante demanda no cenário da epidemia da aids.

Outra barreira de acesso aos insumos de prevenção foi a vinculação da entrega dos mesmos à obrigação de que as travestis participem de palestras e/ou se identifiquem por meio da documentação civil, como Registro Geral (RG), certidão de nascimento ou "carteirinha do SUS" (como popularmente ficou conhecido o Cartão SUS, visto adiante). Segundo representante do movimento de pessoas trans, tais práticas costumam afugentá-las dos serviços de saúde, uma vez que os assuntos debatidos nas palestras lhes parecem enfadonhos e repetitivos; por sua vez, muitas travestis também preferem não apresentar documentos de identificação por não os possuir em mãos, por receio de conflitos com a lei ou por medo de serem discriminadas em razão do seu nome de

Disponível

$\mathrm{em}$

em: http://www.aids.gov.br/sites/default/files/anexos/event/2012/51362/programacao_seminario_pdf_12013.p df.

${ }^{66}$ Neste seminário facilitei o grupo "Populações mais vulneráveis e os desafios para o enfrentamento das DST/HIV/Aids e Hepatites Virais", que contou com a presença de cerca de 70 ativistas, convidados pelo Ministério da Saúde para debater o cenário atual e as novas demandas para a garantia dos direitos humanos das pessoas que vivem com HIV/aids e hepatites virais no Brasil.

${ }^{67}$ Segundo recomendação do Departamento de DST/AIDS e Hepatites Virais a quantidade de preservativos deve ser negociada, a "cota negociada", e não deve estar atrelada necessariamente a nenhuma palestra ou prática educativa, a ideia é aumentar a adesão e o uso e não criar impedimentos desnecessários, devendo o gestor se atentar para as necessidades acrescidas das travestis, transexuais, profissionais do sexo, entre outros. [Citado em 2014 nov. 23]. Disponível em: www.aids.gov.br/pagina/insumos-de-prevencao. 
batismo. Cabe salientar que o descontentamento em relação ao fornecimento dos insumos de prevenção não é uma novidade, em 2007 a pesquisadora Larissa Pelúcio (112) já mencionava o desagrado das travestis em relação às cotas mensais de preservativos e as formas de vinculação dos indivíduos aos serviços de saúde. Desde aquela época, motivadas pela necessidade de ampliar o acesso da população à testagem do HIV, sífilis e hepatites, intensificando o controle da prevenção da transmissão vertical (procedimentos que exigem um contato mais prolongado com o público), os serviços de saúde buscavam "atrair a clientela até o posto" atrelando a entrega dos insumos a consultas, práticas educacionais, entre outras, de modo a estabelecer vínculo do usuário com o sistema e assim administrar e controlar uma série de procedimentos relativos aos cuidados de saúde dessa população, ainda conforme Pelúcio (112).

Ainda em relação ao tema, segue a Autora, é necessário considerar a inadequação dos discursos preventivos sobre o uso "obrigatório" de preservativos em todas as relações, uma vez que esta imposição não corresponde, na maior parte das vezes, ao desejo das pessoas nem a visão que estas têm sobre amor e compromisso, incluindo as travestis. $\mathrm{O}$ uso de preservativo é visto por muitas travestis como um "separador" entre os "parceiros sexuais esporádicos e clientes" e os "parceiros amorosos"; a escolha em não usar a camisinha é, inclusive, citado como um diferencial entre estes dois grupos.

No senso comum, a capacidade afetiva e amorosa está circunscrita exclusivamente nas relações heterossexuais, a dificuldade de ajuizar que alguns grupos populacionais como gays, profissionais do sexo e travestis - se envolvam afetiva e amorosamente provavelmente ilustre a forma normativa e medicamentosa com a qual se preconiza, particularmente, o uso do preservativo para estes grupos em todas as relações sexuais, sem exceção ou possibilidade de estabelecer diálogo sobre a dificuldade em utilizar a camisinha nas relações com parceiros estáveis, como com os/as namorados/as e maridos/mulheres.

Ao disponibilizar preservativos e gel lubrificante exclusivamente em centros de saúde, ou ainda vincular a disponibilidade dos insumos a participação obrigatória em ações educativas e inscrição em cadastros institucionais, desconsidera-se todo o contexto de vida e socialização das travestis, que em grande parte foram "expulsas" de diferentes instituições e centros de educação formal e têm na rua (e não nos centros de saúde ou educação) o espaço de socialização, aprendizado e trabalho. A rua, o lócus onde se 
relacionam e encontram opções para a própria subsistência, é geralmente ocupado pelo Estado não por promotores de saúde, mas por policiais e agentes de controle. Tais procedimentos não garantem o direito à dignidade, tampouco proporcionam um encontro real e interessado nesta população.

Para o enfrentamento dos determinantes que impedem o acesso a serviços e insumos de prevenção, operadores da saúde devem ser estimulados a compreender o significado de "bem estar e saúde" para as diferentes comunidades, de maneira a propiciar o desenvolvimento de práticas que considerem as diferentes realidades, conforme Lorenzo C., Ferreira O. (113):

Para ser capaz de desenvolver a saúde, em seu conceito amplo, as políticas públicas devem buscar desenvolver conjuntos capacitários das comunidades a que se destinam, para que seus membros possam realizar-se plenamente em matéria de promoção, proteção e recuperação da saúde.

Lorenzo C. e Ferreira O. (113) igualmente lembram que decisões em meios multiculturais não devem estar fundamentadas, do ponto de vista filosófico, em princípios doutrinários - religiosos, ideológicos e científicos - e nem podem estar apoiados em valores próprios de uma única cultura, as ações de saúde devem ser previamente planejadas e estabelecidos pela linguagem e pela argumentação e não pela esperança vã da "transformação da consciência". Neste contexto, é possível prever a necessária participação das comunidades envolvidas no planejamento e implementação de estratégias em saúde. Os encontros deveriam ocorrer no "campo do saber", onde as ações seriam planejadas e decididas a partir de uma racionalidade comunicativa, praticadas no interior de espaços democráticos de discussão, ao contrário do que corriqueiramente ocorre nos discursos herméticos e higienistas da prevenção.

As questões apresentadas trazem uma reflexão sobre a relação entre saúde coletiva e os direitos individuais. Ainda segundo Lorenzo C. e Ferreira O. (113), do ponto de vista ético, a saúde como um direito de todos significa, ao mesmo tempo, saúde como direito de cada um. As estratégias em saúde coletiva necessitam também “abranger o caráter subjetivo existente na expressão das necessidades de grupos culturalmente diversos e em desvantagem social". Neste sentido, concordando com Pelúcio (102), alerta-se que embora as políticas de aids estabeleçam seus parâmetros com base no marco dos direitos humanos, isso tem sido insuficiente para garantia de estratégias equitárias, uma 
vez que, do ponto de vista programático, a homogeneização de condutas permanece soberana, ainda que temas como diversidade, equidade e direitos individuais estejam presentes nos discursos e documentos nacionais e internacionais. 


\section{FACETAS DA VIOLÊNCIA E RELAÇÃO COM A INFECÇÃO PELO HIV/AIDS}

Os estudos sobre travestis têm apontado que fatores relacionados com a violência transfóbica são determinantes para o acréscimo de vulnerabilidades e risco à infecção para o HIV e adoecimento em decorrência da aids. No Brasil não são poucos os relatos sobre o contexto de violência associado à população LGBT, no entanto, em relação às travestis e transexuais o grau de exposição a atos de violência, bem como o tipo de violência e suas consequências, é distinto e precisa ser compreendido em suas particularidades. Numa pesquisa realizada pela Fundação Perseu Abramo (114), demonstrou-se que em relação a existência de preconceito contra as pessoas LGBT no Brasil, num universo de 2.014 pessoas entrevistadas, 93\% acreditam que existe preconceito contra travestis (para $73 \%$ muito, para $16 \%$ um pouco), porém indagados se são preconceituosos, somente $29 \%$ admitiram ter preconceito contra travestis e só $12 \%$ muito.

Ainda sobre este tema, de acordo com o $2^{\circ}$ Relatório Sobre Violência Homofóbica (115), o número de denúncias de violência efetuadas junto ao poder público cresceu 166\% no ano de 2012 em relação ao ano anterior, saltando de 1.159 para 3.084 registros. Mesmo considerando as subnotificações de violência naquele ano, a cada dia foram 13,29 pessoas vítimas deste tipo de violência no país. Ainda que os dados que compõe este relatório apresentem limitações ${ }^{68}$, tal documento mostra-se importante pela possibilidade de visibilizar, quantificar e comparar a realidade de violações dos direitos humanos vividas por esta população:

As violações dos direitos humanos relacionadas à orientação sexual e identidade de gênero, que vitimizam fundamentalmente a população LGBT, constituem um padrão que envolve diferentes espécies de abusos e discriminações e costumam ser agravadas por outras formas de violências, ódio e exclusão, baseadas em aspectos como idade, religião, raça/cor, deficiência

\footnotetext{
${ }^{68}$ No relatório são descritas as seguintes limitações: não obrigatoriedade de reportação de dados referentes à segurança pública para a União, por parte de cada uma das unidades da federação; ausência de campo relativo a orientação sexual, identidade de gênero ou possível motivação homofóbica em boletins de ocorrências policiais e a escassez de dados demográficos referentes à população LGBT. Importante observar que as denúncias realizadas junto ao poder público federal não precisam ser efetuadas pela própria vítima. Segundo o relatório, $47,3 \%$ dos casos não conheciam as vítimas anteriormente, $10,49 \%$ das denúncias foram feitas pelas próprias vítimas e 3,32\% dos casos denunciados, tratavam-se de conhecidos da vítima. Este fato pode dificultar o registro fidedigno do perfil, uma vez que categorias como "orientação sexual" e "identidade de gênero", bem como suas diferenciações, não são amplamente conhecidas entre a população. Vide nota anterior.
} 
e situação socioeconômica. Essa superposição de vitimizações exacerba a vulnerabilidade de grupos sociais, cuja discriminação é intensificada quando ao racismo, sexismo, pobreza ou credo agrega-se orientação sexual e/ou identidade de gênero estigmatizadas (116).

O relatório mostra que em relação ao perfil da violência homofóbica, no quesito orientação sexual, em 2011: 85,5\% das vítimas foram relatadas como homossexuais (categoria onde se encontram também travestis e transexuais); 9,5\% como bissexuais; e, 1,6\% como heterossexuais. Já em 2012, apenas 17,02\% das denúncias informava sobre orientação sexual ou identidade de gênero das vítimas, dentre as quais 60,44\% foram identificadas como gays, 37,59\% como lésbicas e apenas 1,94\% dos casos se referiam às travestis e transexuais. Veja-se o quadro abaixo:

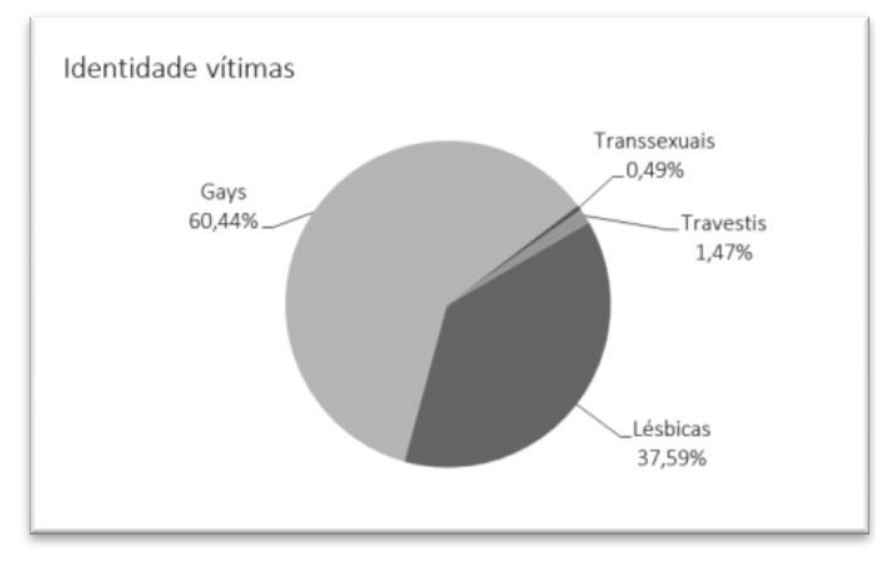

Figura 03: Gráfico das vítimas de violência classificadas por identidade em 2012. Fonte: Relatório sobre violência homofóbica no Brasil.

Importante notar que a baixa notificação de denúncias contra pessoas trans não significa a ausência de violações, ao contrário, segundo o referido relatório, as categorias "orientação sexual" e "identidade de gênero", bem como suas distinções, ainda são bastante desconhecidas pela população em geral, o que reforça a invisibilidade, sobretudo em relação ao grupo de travestis e transexuais, tornando-se mais um obstáculo para o registro da denúncia.

Ainda referindo-se ao perfil das vítimas, em relação ao quesito raça/cor auto declarada: negros (pretos e pardos) totalizam 40,55\% das vítimas, seguidos por brancos, com 26,84\%. A faixa etária das vítimas concentra-se na população jovem, sendo $61,16 \%$ entre 15 e 29 anos. Combinando estes marcadores, percebe-se que a maior parte das 
vítimas são jovens e negras.

Em relação ao local de ocorrência dessas violações, a falta de segurança está tanto nos espaços públicos quanto nos espaços privados, sendo: 38,63\% nas casas, seja da vítima $(25,54 \%)$, do suspeito $(7,76 \%)$, de ambos ou de terceiros; seguido pela rua, com $30,89 \%$ e em outros locais com 19,88\%, dentre eles, ônibus, unidade prisional, manicômio ou hospital psiquiátrico, casa de saúde, instituição de longa permanência para idosos, delegacia de polícia e unidade de medida sócio educativa.

Os dados acima corroboram com aqueles referidos por Peres (117), nos quais se identifica que as violações de direitos relacionadas à orientação sexual e à identidade de gênero ocorrem na rua mas também nas suas próprias casas, local onde se suporia idealmente maior segurança, proteção e cuidado. Segundo este Autor, a primeira experie $\square$ ncia de estigmatização no contexto familiar acarreta um processo de diminuição da autoestima e da confiança em si mesmo:

Ao contrário do processo de empoderamento, as pessoas que fogem às normas de sexo/gênero/desejo regulados pela norma heterossexual, se não encontram fortalecimento nas relações positivas de pertença, tornam-se enfraquecidas diante das experie $\square$ ncias de estigmatização que, por si mesmas, geram sensações de angústias, depressões e outros adoecimentos físicos e psíquicos (117).

O quadro abaixo refere-se aos locais de violações reportados no ano de 2012, segundo o citado relatório sobre violência homofóbica:

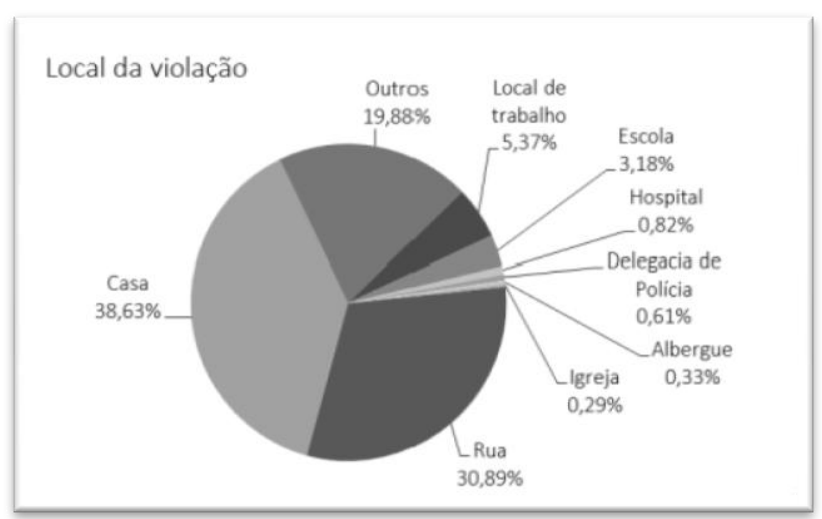

Figura 04: Gráfico dos locais de violações em 2012. Fonte: Relatório sobre violência homofóbica no Brasil. 
Dentre os tipos de violações mais denunciadas no ano de 2012, têm-se: violências psicológicas (83,2\%); discriminação (74,01\%); violências físicas (32,68\%); negligências $(5,7 \%)$; violências sexuais $(4,18 \%)$ e violências institucionais $(2,39 \%)$.

Outro relatório sobre violações de direitos da população LGBT, também produzido pela Secretaria de Direitos Humanos da Presidência da República, baseou-se em dados hemerográficos $^{69}$, divulgados nos principais canais midiáticos do país no ano 2012, revelou que naquele ano foram registrados 511 violações contra a população LGBT, envolvendo 511 vítimas e 474 suspeitos. Entre as violações noticiadas, há 310 homicídios, acréscimo de $11,51 \%$ em relação a 2011, que aponta um aumento nos homicídios contra LGBT, mais acentuadamente entre as travestis e transexuais, que sofrem mais violência do que as demais categorias que compõem esse universo.

Ainda de acordo com esta pesquisa, no ano de 2011 a maioria das vítimas de homicídios foi identificada como travesti, sendo: $49 \%$ travestis, seguidas pelos gays $46 \%$ e lésbicas 3,2\%; já em 2012, 40\% das vítimas foram identificadas como travestis. Vale ressaltar que muitas notificações registradas como gays, na realidade tratam-se de travestis e mulheres transexuais.

O quadro abaixo refere-se aos casos de homicídio contra travestis no ano de 2012, segundo o Relatório sobre violência homofóbica no Brasil:

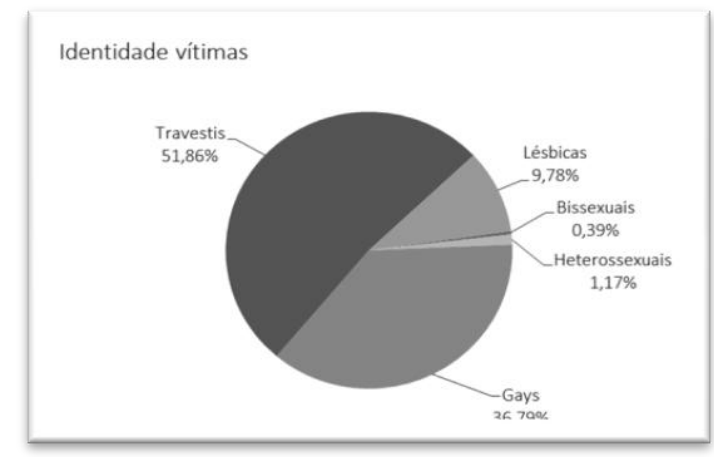

Figura 05: Gráfico da identidade das vítimas de violações no ano de 2012, segundo o Relatório sobre violência homofóbica no Brasil.

Em que pese as diferenças metodológicas e de perspectivas, os dados apresentados

\footnotetext{
${ }^{69}$ Os dados foram baseados em notícias veiculadas na imprensa. A importância da apreciação deste tipo de estatística é que se trata da metodologia utilizada pelos movimentos sociais LGBT no Brasil, de forma pioneira, desde a década de 1980, já havendo estabelecido notável série histórica.
} 
nestas pesquisas coincidem ao indicar que as travestis compõem um dos grupos mais vitimados por homicídios, sendo $51,68 \%$ do total, seguidas por gays $(36,79 \%)$, lésbicas $(9,78 \%)$, heterossexuais $(1,17 \%)$ e bissexuais $(0,39 \%)$.

Em relação as vítimas de homicídio, 27,74\% são negras, $15,16 \%$ brancas e em 57,10\% dos casos a raça não foi informada. Grande parte das vítimas são jovens, já que 42,9\% tem entre 14 e 29 anos; por sua vez, 19,35\% tem entre 30 e 39 anos, seguido dos $10,65 \%$ entre 40 e 49 anos, sendo que em $34,8 \%$ dos casos não foram informadas as idades.

O local de violação, segundo os dados hemerográficos, confirmam a prevalência da rua $(35,67 \%)$ e residência $(23,59 \%)$ como principais locais de ocorrência; vale notar, conforme gráfico abaixo, que as instituições governamentais e escolas também aparecem como espaços nos quais são reportadas violações de direitos:

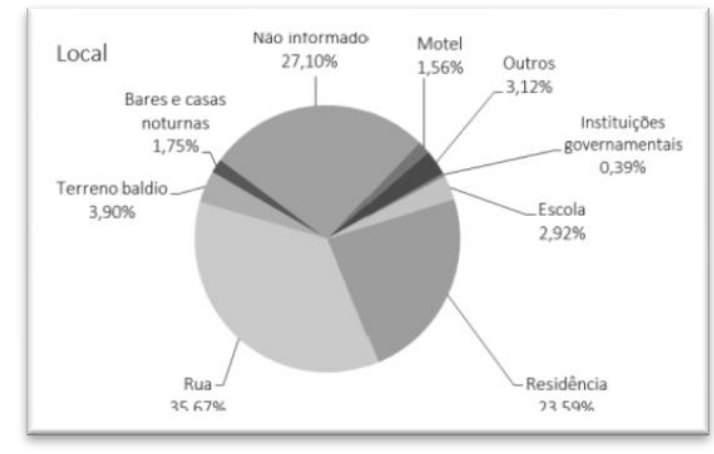

Figura 06: Gráfico dos locais de ocorrência no ano de 2012, segundo o Relatório sobre violência homofóbica no Brasil.

A partir de tal cenário, percebe-se que a violação de direitos é constante na vida de travestis, e na medida em que se afirmam tais direitos também se aperfeiçoam as formas de discriminação, violência e intolerância, inclusive na esfera pública. Assim, as experiências de violência vivenciadas por travestis se intensificam na sobreposição de estigmas, isto é, ser pobre, negra ou estar vivendo com HIV/AIDS, darão cores e sentidos distintos aos diversos modos de estigmatização. Segundo Teixeira (104):

A aids nesse universo se constitui como uma profecia auto realizadora por meio da qual as travestis, por se julgarem a priori como infectadas pelo HIV, em decorrência de sua travestilidade, deixam de se proteger e então se infectam. Apesar de amplamente compartilhado, tal destino é sempre velado. Ele é compartilhado, mas pouco discutido ou explicitado. Há como um pacto de silêncio em relação a ele. Assim, a infecção pelo HIV, quando ocorre, é tipicamente vivida de forma isolada. Identificar-se no grupo como uma travesti portadora do HIV 
parece transgredir tal acordo grupal, o que pode gerar diferentes penalidades.

Desta forma, a naturalização e a banalização da violência no universo cotidiano das travestis compõem suas experiências subjetivas, que são construídas por meio do enfrentamento da vergonha e do estigma. Tal processo compõe um território de medo e terror atrelado à expectativa de morte e ao risco de adoecimento em decorrência da aids.

O fenômeno da violência relacionada à desigualdade de gênero e orientação sexual vem sendo relatado há quase cinquenta anos através das reivindicações do movimento LGBT. Na década de 70, durante o processo de redemocratização do Brasil, o movimento se afirma enquanto um "projeto" de politização das questões referentes à homossexualidade e como principal interlocutor de uma diversidade de reivindicações relacionadas à violência, aos direitos humanos, gênero e à sexualidade das chamadas "minorias sexuais"70.

Em 1978, na cidade do Rio de Janeiro, a "voz das minorias interditadas" tem como marco inicial o jornal "Lampião de Esquina", que publica as principais reivindicações destes movimentos, como a inclusão do respeito à "opção sexual"71, conforme Trevisan (118). Nos primórdios, o Movimento LGBT foi constituído predominantemente por gays, porém, após os primeiros anos de atividade, as lésbicas começam a se afirmar como sujeito político relativamente autônomo. É na década de 90 que as travestis e transexuais passam a participar mais intensamente e de maneira mais organizada do movimento, conforme Facchini (119).

Nos anos 80, houve uma ampla mobilização em prol dos direitos homossexuais, ativistas deste movimento organizaram-se em encontros regionais, donde surgiram passeatas contra a violência policial e a primeira campanha nacional para retirar a homossexualidade do código de doenças do Instituto Nacional de Assistência Médica da Previdência Social (INAMPS), iniciando-se aí a luta pela despatologização da

\footnotetext{
${ }^{70} \mathrm{~A}$ expressão minoria não pretende se referir ao quantitativo numérico, mas a uma atribuição valorativa que é imputada a um determinado grupo a partir da ótica dominante. Conforme a revista La Gandhi Argentina (1998), as minorias nunca poderiam se traduzir como uma inferioridade numérica, mas sim como maiorias silenciosas que, ao se politizar, convertem o gueto em território e o estigma em orgulho gay, étnico, de gênero (194).

${ }^{71}$ O termo "opção sexual" é utilizado na época pelo próprio movimento, sendo substituído posteriormente pelo termo "orientação sexual".
} 
homossexualidade. Tais mobilizações culminaram na criação do Movimento Nacional LGBT em 1995, conforme Facchini (119).

Esta década também é marcada pelo surgimento da epidemia de aids, que repercute no recrudescimento do preconceito e da homofobia. No Brasil, os primeiros casos de aids ocorreram entre homens gays, brancos, de classe média ou alta, moradores dos centros urbanos, daí que os homossexuais masculinos passam a ser considerados como "grupo de risco", vetores da doença, portadores de distúrbios e perversões, uma associação entre aids e homossexualidade que leva a imprensa e os meios científicos a nomear a doença inicialmente como GRID, Gay Related Immunedeficiency, câncer gay ou peste gay (120).

A epidemia da aids foi um evento marcante, tanto por sua disposição avassaladora, quanto pela capacidade de resposta e solidariedade, sobretudo entre os grupos particularmente afetados. Diante do crescimento dos casos da doença e da demora nas respostas governamentais, militantes homossexuais passam a se mobilizar contra a epidemia, no âmbito da assistência solidária à comunidade e na formulação de demandas para o poder público, conforme Facchini, R.(119). Nesta linha, para Trevisán:

Os homens gays precisavam lutar contra um governo negligente que ignorava a morte de seus cidadãos. Assim, a disseminação rápida inicial da Aids pela população gay do Brasil preencheu, em poucos meses, o papel delicado e importante que o movimento gay havia tentado por anos em vão; e isso mostrou à nação inteira que os homossexuais não viviam em outro país, mas em cada esquina do Brasil (121).

E se por um lado houve um aumento do estigma e do preconceito decorrentes da associação entre aids e homossexualidade, por outro, a doença trouxe visibilidade aos temas relacionados à homossexualidade, permitindo ao conjunto da sociedade refletir sobre a experiência sexual de maneira mais ampla ${ }^{72}$. Neste contexto, os movimentos sociais tiveram que se fortalecer para enfrentar os desafios impostos pela epidemia, uma mobilização geradora de importantes respostas para o enfrentamento do HIV/AIDS,

\footnotetext{
${ }^{72}$ Segundo Seara LN, 2011 com a epidemia, temas que eram tidos como absolutamente privados, envoltos em tabus e mitos, se tornaram assunto de interesse público, mobilização social e objeto de políticas públicas, incorporados a discussões diversas e a publicização como questões sociais relevantes
} 
como a criação de diversas organizações não-governamentais $(\mathrm{ONG})^{73}$ com atuação em HIV/AIDS e direitos humanos, que por sua vez fomentaram as primeiras produções de materiais informativos sobre formas de transmissão, sexo seguro, promoção dos direitos humanos e da solidariedade como princípios básicos do trabalho de prevenção, conforme Terto Jr. (122).

Segundo Facchini (119), é no encontro nacional de ativistas ocorrido em 1984, na Bahia, que temas como a despatologização da homossexualidade, legislação antidiscriminatória, tratamento positivo da homossexualidade na mídia e a inclusão da educação sexual nos currículos escolares, passam a ser reivindicados pelo movimento LGBT. Cinco anos depois, no encontro nacional de 1989, temas como aids, violência, discriminação e o fortalecimento dos atores e movimentos sociais passam a compor o rol de reivindicações da agenda do movimento homossexual. Ainda segundo a Autora, é nos anos de 1990 e 1991 que a luta contra a aids assume uma dimensão ainda maior, o que gera uma crise na organização dos movimentos, que deixam de se concentrar em suas pautas anteriores para centralizar esforços nas respostas em relação à aids.

Durante a década de 1990 o Brasil torna-se referência internacional na resposta a epidemia de aids, contando com o reconhecimento internacional da parceria entre organizações governamentais (OG) e as organizações da sociedade civil (OSC) como uma "marca brasileira". As organizações sociais se multiplicaram e, em parceria com organismos internacionais e com os programas governamentais, passaram a desenvolver projetos, intervenções comunitárias, campanhas e a distribuição de insumos de prevenção para o enfrentamento do HIV/AIDS.

O pesquisador Terto Jr. (123), em 2002, discorre sobre a gravidade da associação limitadora entre "aids e homossexualidade" e os novos desafios para a população de homossexuais; para ele, a representação dos homossexuais como vilões e/ou vítimas permanece acarretando individualmente na homo/transfobia.

\footnotetext{
${ }^{73} \mathrm{O}$ termo organização não governamental (ONG), assim como organização da sociedade civil (OSC), não tem uma definição legal no Brasil, mas é utilizado para representar genericamente aquelas institucionalidades não ligadas ao Poder Público, afirma seu não lugar no governo, muito em função do contexto da ditadura. Para ter reconhecimento formal no Brasil, uma ONG (ou OSC) deve ter a natureza jurídica de fundação ou associação, conforme o Código Civil, em capítulo específico sobre as pessoas jurídicas de direito privado (art. 40 e seguintes do Código Civil Brasileiro). [citado em 2014 out. 13] Disponível em: http://www.planalto.gov.br/ccivil_03/leis/2002/L10406.htm\#tituloii.
} 
Passada uma década, o tema "aids e violência" se mantém atualizado e, como outrora, a epidemia e a violência se impõem como problemas que se tramam e exigem respostas de diferentes setores governamentais e da sociedade civil, de modo que recursos sejam garantidos e aplicados na prevenção e assistência, assim como no enfrentamento ao estigma, discriminação e homo-transfobia. 


\section{PARA ALÉM DE DADOS EPIDEMIOLÓGICOS...}

\subsection{O CONTEXTO NACIONAL.}

Nos últimos 15 anos atuando no enfrentamento do HIV/AIDS, sistematicamente escuto de profissionais de saúde, gestores e representantes de movimentos sociais que um dos principais motivos para o menor direcionamento das políticas públicas (em outros termos, menor alocação de recursos) no campo da prevenção do HIV/AIDS no Brasil para a população de travestis, se deve à falta de dados sobre a prevalência da doença neste grupo populacional.

Em que pese a escassez de dados com abrangência nacional, apresenta-se aqui os resultados da revisão bibliográfica nacional e internacional sobre contextos de vulnerabilidades e prevalência do HIV/AIDS entre pessoas trans, nos quais é possível inferir que neste grupo a prevalência supera substancialmente outras categorias populacionais como gays, usuários de drogas e profissionais do sexo.

Em termos nacionais, o Ministério da Saúde utiliza a categoria de "exposição HSH" para a população de travestis ${ }^{74}$. Segundo os dados do Boletim Epidemiológico de Aids e DST de 2013 (124), entre os anos de 1980 a junho de 2013 no Brasil, foram notificados um total de 686.478 casos de aids, dos quais 445.197 (64,9\%) são do sexo masculino e $241.223(35,1 \%)$ do sexo feminino. Sendo que nos últimos 10 anos, de 2003 a 2012, foram notificados 37.446 casos de aids por ano, com tendência de aumento no Brasil como um todo.

A epidemia do HIV no Brasil está concentrada em populações em situação de maior risco e vulnerabilidade, pois estas apresentam maiores prevalências de infecção pelo HIV quando comparadas a população geral: em 2012, no Brasil, a taxa de detecção de casos de aids em homens de 15 a 24 anos foi de 15,1/100.000 habitantes e de 8,6 em mulheres.

Em relação aos grupos populacionais em situação de maior vulnerabilidade, com mais de 18 anos, as taxas de prevalência de HIV são: 5,9\% entre UD (usuários drogas) (125), de 10,5\% entre HSH (126) e de 4,9\% entre PS (mulheres profissionais do sexo) (127).

\footnotetext{
${ }^{74}$ Em 2013, o Departamento de DST, AIDS e Hepatites Virais do Ministério da Saúde iniciou o processo de inserção da categoria travesti e homens e mulheres transexuais nos sistemas nacionais de vigilância epidemiológica, com base nas deliberações da I Conferencia Nacional LGBT.
} 
Na última década, os casos de aids entre pessoas de 17 a 21 anos têm aumentado, passando de 0,09\% em 2002 para 0,12\% em 2007, sendo que o aumento mais significativo ocorreu na população de HSH jovens, cuja prevalência subiu de $0,56 \% \mathrm{em}$ 2002 para $1,2 \%$ em 2007, alertando para a relevância do segmento populacional de jovens gays e HSH no montante de infecções.

No ano de 2012, na faixa etária de 13 anos de idade ou mais, do total de 16.464 casos de aids no sexo masculino, $18,3 \%$ não possuem a informação da categoria de exposição. Entre os que apresentam essa informação (13.447), 32,0\% são homossexuais, 9,4\% bissexuais, 52,7\% heterossexuais, 5,2\% usuários de drogas injetáveis (UDI) e 0,7\% ocorreram por transmissão vertical. Nos últimos 10 anos, observa-se um aumento de cerca de $22 \%$ na proporção de casos em HSH e uma reduc $\square$ ão de $3 \%$ de heterossexuais.

No caso dos estudos de prevalência do HIV entre a população trans, deve-se observar as seguintes limitações: não existem estudos com abrangência nacional, de modo geral, os realizados até agora tem abrangência regional e pequenas escalas; geralmente não alcançam uma mostra representativa da população; boa parte dos estudos coloca sobre o mesmo "guarda-chuva" diferentes perfis de populações trans, sendo difícil identificar se as estimativas de prevalência referem-se à mulheres trans, travestis, transgêneros ou outros. Com efeito, o termo transgênero, que tem dominado a literatura internacional, abrange uma série de categorias: travestis, transexuais pré e pós operadas, “crossdresser", transformistas e drag queens ${ }^{75}$. Tais categorias, além de diferentes entre si, podem adquirir significados diversos a depender do contexto local.

Os indicadores quantitativos são, em sua maioria, imprecisos no que se refere à porcentagem destas pessoas em relação ao número total de pessoas trans num determinado local ou país. Situações e práticas sexuais de risco para a infecção pelo HIV, além de outros fatores, como o consumo de drogas intravenosas e os contextos nos quais estas substâncias são consumidas, não estão suficientemente documentados, conforme Giami, A; Bail, J; (128). Importante notar também, conforme apontado por Boehmer (129), que pessoas trans não envolvidas com uso de drogas ou trabalho sexual ou que estão bem integradas socialmente parecem ser pouco estudadas.

\footnotetext{
${ }^{75}$ Para maior informação dos termos: "crossdresse"; "transformistas"; "drag queen" sugere-se a leitura do livro: Sopa de letrinhas?: movimento homossexual e produção de identidades coletivas nos anos 90. (195).
} 
Em nível regional, o "Estudo descritivo da homofobia e vulnerabilidade ao HIV/AIDS das travestis da região metropolitana do Recife" (130) demonstra consonância com os achados de outras pesquisas regionais e estudos internacionais citados no decorrer deste trabalho. Por apresentar dados relevantes para as discussões aqui realizadas, optou-se por apresentar mais detalhadamente esta pesquisa e confrontá-la com achados de outros investigadores, entendendo sua importância como referência para os fenômenos relacionados à situação epidemiológica e os contextos de vulnerabilidade da população de travestis no Brasil. Além disso, está em consonância com grande parte da literatura internacional sobre os contextos de vulnerabilidades desta população, conforme se verá a seguir. Em relação à metodologia a pesquisa utilizou-se do método amostral “Respondent Driven Sampling (RDS)”, e foi realizada pela Faculdade de Ciências Médicas da Universidade de Pernambuco, em parceria com o Ministério da Saúde. Contou com a participação de 110 travestis da região metropolitana de Recife/PE, com média de idade de 28,4 anos, das quais 78,2\% foram classificadas como negras e pardas, observando uma taxa de analfabetismo de 9,2\% e analfabetismo funcional de $17,4 \%$ (< 4 anos de estudo), sendo que 44,9\% não concluíram o ensino fundamental.

Em relação ao abandono escolar, 32,2\% referiram que o motivo deveu-se ao fato de ser travesti e 48,2\% informaram que já tinham sido maltratadas por colegas ou professores. Por sua vez, a discriminação no ambiente familiar, ou em grupos de amigos e vizinhos, foi relatada por $47,3 \%$ das entrevistadas. Da mesma forma que evidenciado por Benedetti (131), a grande maioria das travestis entrevistadas deixou suas respectivas famílias pela primeira vez antes de completar 18 anos de idade, dentre outros motivos, por sofrer violências e discriminação.

A menor permanência de travestis nas escolas parece corresponder com os achados de Cruz (132) e Peres (133), ao destacarem que a garantia de acesso ao ensino escolar passa por questões complexas, como o uso do banheiro (qual banheiro se destinará às travestis?), perpassando pela resistência ao tratamento e aceitação do nome feminino, pelo preconceito e incompreensão de como alguém que nasceu com pênis, "portanto tido como homem", possa se mostrar com uma "inconcebível" identidade de gênero feminina. 
Em relação à classe econômica, na pesquisa realizada em Recife/PE observou-se que quase a metade $(49,6 \%)$ das entrevistadas pertencia às classes econômicas $\mathrm{D}$ e $\mathrm{E}^{76} \mathrm{e}$ apenas $8,2 \%$ conseguiram alcançar a classe econômica B. Marca-se a diferença entre o grupo social pesquisado e a média da população brasileira, onde apenas $1,6 \%$ dos indivíduos pertencem ao extrato social D e E. Mesmo entre o grupo classificado como $\mathrm{HSH}$, o pertencimento às classes D e E é menor do que entre travestis, correspondendo a 23,3\%, de acordo com o Critério de Classificação Econômica Brasil ${ }^{77}$.

Segundo a pesquisa, o índice de travestis que contribuem com a previdência social é ínfimo, comparado ao percentual de contribuintes entre a população brasileira, já que 4,5\% das entrevistadas estavam contribuindo com a previdência social, enquanto na população brasileira, em 2009, esse percentual foi 53,5\%.

Em relação a situações de violência, destacam-se: agressão verbal $(81,8 \%)$ e física $(68,2 \%)$; maltrato por policiais e/ou mau atendimento em delegacias $(56,4 \%)$; discriminação no ambiente religioso $(50,9 \%)$ e nos serviços de saúde $(31,8 \%)$.

Corroborando com os dados sobre violência contra a população LGBT encontrados por pesquisadores como Carrara S et al. (134), Carrara S. et. al. (135) e pela Secretaria de Direitos Humanos (136), igualmente no estudo realizado em Recife/PE é possível identificar que os índices de discriminação nas instituições de saúde são inferiores em relação às demais instituições governamentais.

No campo da prevenção do HIV/AIDS, o estudo demonstrou que entre as entrevistadas, $84 \%$ referiram já ter realizado algum teste de HIV durante a vida e 47,3\% o fizeram nos últimos 12 meses, indicando que as travestis desta pesquisa fizeram mais testes do que a maioria das pessoas no Brasil, incluindo gays e HSH (137); entretanto, não é possível saber quantos testes foram realizados ao longo da vida das participantes.

Em relação ao local de realização do teste para o HIV, 90,2\% das entrevistadas acessaram a rede pública, resultado maior do que o encontrado entre $\mathrm{HSH}$, que ficou em

\footnotetext{
${ }^{76}$ A classificação econômica desta pesquisa está de acordo com aquela proposta pelo Instituto Brasileiro de Geografia e Estatística (IBGE). [citado em 2014 set 13]. Disponível em: www.ibge.gov.br.

${ }^{77}$ Associação Brasileira de Empresas de Pesquisa (ABEP). Critério de Classificação Econômica Brasil, (Internet) Brasil: ABEP; 2010 [citado em 2012 dez 5]. Disponível em: http://www.abep.org/novo/Content. aspx?ContentID=302
} 
66,7\%. A prevalência de HIV referida pelas travestis foi de $12,7 \%$, resultado que se aproxima ao encontrado entre HSH, que foi de 10,5\%. Em relação a tais dados, observase que por ocasião da pesquisa, cerca de $50 \%$ desconheciam sua sorologia dos últimos 12 meses, portanto, é possível aferir que a prevalência de 12,7\% possa não corresponder a um número exato nesta população.

Vale registrar também que 34,5\% das entrevistadas referiram conhecer alguma ONG que trabalha com HIV/AIDS, e em relação ao movimento homossexual, por sua vez, cerca de $40 \%$ participam ou já participaram. As entrevistadas demonstraram um bom conhecimento sobre as formas de prevenção e transmissão do HIV/AIDS, e, embora acreditem na importância das estratégias adotadas para o enfrentamento da epidemia por parte do governo, tais como acesso à informação e aos serviços públicos para diagnóstico precoce, advertem que tais estratégias deveriam ser ampliadas e adequadas aos contextos de vida das travestis.

Este estudo demonstrou ainda que $82,7 \%$ das participantes iniciaram sua vida sexual antes dos 15 anos de idade e sem preservativo (87\%), tendo como média de idade da primeira relação sexual 12 anos, sendo que a travesti que teve sua primeira relação com mais idade tinha 19 anos e a mais jovem, 7 anos.

Estes dados demonstram que as travestis tiveram iniciação sexual mais cedo que a população em geral, comparando-se aos dados encontrados na Pesquisa de Conhecimentos, Atitudes e Práticas - PCAP (138), onde apenas 26,8\% referiram relações sexuais antes dos 15 anos de idade.

Em relação ao tipo de parceria sexual, o estudo de Recife/PE demonstrou que cerca de $60,2 \%$ das travestis informaram não ter parceiro sexual fixo no período em que a pesquisa foi realizada e $71,8 \%$ expuseram ter tido relação sexual comercial nos 12 meses anteriores à entrevista. Referindo-se a tais relações, cerca de $91 \%$ das entrevistadas afirmaram usar preservativo, em comparação a 8,9\% que não utilizaram, e $1,5 \%$ que foram forçadas a fazer sexo sem preservativo. Embora a pesquisa não apresente dados sobre o uso de preservativo com parceiros estáveis ${ }^{78}$, como namorados,

\footnotetext{
${ }^{78}$ Parceiros estáveis foram definidos, pela pesquisa, como pessoas com as quais os participantes tinham um relacionamento, tais como namorados ou cônjuges. Parceiros casuais foram definidos como parceiros com os quais os participantes envolvidos em relações sexuais casuais, ou em uma única noite. Parceiros sexuais comerciais foram definidos como clientes que pagaram por sexo
} 
maridos ou parceiros afetivos/amorosos, os estudos brasileiros aqui citados demonstraram que o uso de preservativo varia de acordo com o tipo de parceria, classificadas como casual, comercial ou estável, sendo que nestas últimas, as chamadas “estáveis", o uso do preservativo é reduzido.

Por fim, o estudo de Recife/PE ratificou o entendimento de que as interações sociais podem agravar vulnerabilidades, graças a fatores como racismo, geração, transfobia e pobreza. Tais dados corroboram a ampla literatura do campo do HIV/AIDS que aponta que $90 \%$ das infecções por HIV no mundo ocorrem em países em desenvolvimento, demonstrando a influência de uma complexidade de fatores estruturais, sociais, econômicos e políticos nas diversas vulnerabilidades relacionadas à infecção e ao adoecimento em decorrência da aids, conforme Gupta, R.; Parkhurst, J; Ogden, J. (139).

A sobreposição de iniquidades e o entrelaçamento das complexas redes que vulnerabilizam as "pessoas trans" torna difícil a compreensão isolada de um ou outro fator que compõem as vulnerabilidades. Por exemplo, mesmo obtendo o menor percentual de discriminação $(31,8 \%$ em relação aos demais serviços públicos ofertados para esta população) a violência transfóbica nos serviços de saúde deve ser evidenciada, pois denota que o direito à equidade e a dignidade não estão sendo respeitados, em que pese serem princípios do SUS que em hipótese alguma deveriam ser suplantados.

Tal entendimento segue o quanto estabelecido na DUBDH, em seu Artigo $8^{\circ}$, quando institui que "grupos mais vulneráveis devem ser protegidos" e no Artigo 11, que ressalta que "nenhum indivíduo ou grupo deve, em circunstância alguma, ser submetido, em violação da dignidade humana, dos direitos humanos e das liberdades fundamentais, a uma discriminação ou a uma estigmatização".

O fato de travestis terem bons conhecimentos sobre prevenção não significa necessariamente que tenham autonomia para fazer uso do preservativo em todas as relações sexuais. Por exemplo, alguns fatores referidos na pesquisa, como serem forçadas a fazer sexo sem preservativo, terem a primeira relação sexual aos 12 anos ou menos, sofrerem toda a sorte de violências, tudo isso deve ser observado enquanto determinantes na dinâmica de risco e vulnerabilidades para a infecção e adoecimento pelo HIV/AIDS. 
Por fim, embora a prevalência de HIV referida pelas travestis na pesquisa $(12,7 \%)$ seja inferior a outros estudos citados no presente trabalho, corroboram com as demais pesquisas elencadas a seguir, nas quais a prevalência do HIV mostra-se bastante alta em relação à média da população brasileira, que é de $0,4 \%$, onde é possível aferir a magnitude deste agravo entre a população trans no Brasil.

\subsection{O CONTEXTO INTERNACIONAL}

Diante da escassez de estudos com abrangência nacional sobre o tema travestis e prevalência de HIV/AIDS, e visando estabelecer um quadro referencial, recorre-se a pesquisas internacionais neste campo por entender que as situações de vulnerabilidade às quais as travestis estão expostas muito se assemelham aos contextos brasileiros, indicando nexos de causalidade entre as dinâmicas sociais e o elevado risco para HIV entre pessoas trans. Ao que pese as diferenças entre países, entende-se que não somente no Brasil o estigma e as vulnerabilidades se assemelham, mais do que se distanciam, conforme se depreende dos estudos efetuados na América Central, El Salvador, Guatemala, Argentina, Chile, Panamá, EUA, França Latina, Europa, Caribe, entre outros.

Pesquisas recentes, realizadas pela United States Agency for International Development USAID na América Central (140), sugerem que a prevalência de HIV entre pessoas trans seja maior do que entre gays e outros HSH. Por sua vez, estudos da Organização Pan-Americana de Saúde (OPAS) (141) indicam que em relação ao HIV e outras DST, as pessoas trans são afetadas até $40 \%$ mais do que a população em geral.

O diagnóstico da USAID (142) acerca da saúde e serviços disponíveis para a população trans mostrou que em El Salvador as taxas de prevalência de HIV entre tal população são de $25,8 \%$, com índice de prevalência da população em geral de $0,8 \%$.

Já na Guatemala, um estudo exploratório (143) sobre conhecimentos, atitudes, percepções e práticas sexuais das pessoas trans que trabalham no mercado sexual encontrou taxas de prevalência de $14,9 \%$, comparado à prevalência de $0,8 \%$ na população em geral. 
Outro estudo (144), realizado pelo Programa Nacional de Aids da Argentina com a colaboração da Asociación de Travestis, Transexuales y Transgéneros de Argentina (ATTTA) e da Fundación Buenos Aires Sida (FBAS), sobre prevalência do HIV entre pessoas trans (2008), indicou a prevalência de $34,47 \%$ entre as profissionais do sexo e $26 \%$ entre aquelas que nunca trabalharam nesta atividade, sendo que em 2012 o índice de prevalência em relação a população adulta em geral era de $0,4 \%$.

Pesquisa qualitativa (145) sobre a vulnerabilidade de pessoas trans no Chile, realizada com 64 participantes trans, revelou que cerca de 47\% reportaram ter sido infectadas e/ou estar infectada por alguma DST, incluindo o HIV. Embora a pesquisa não tenha como objetivo principal o estabelecimento de dados de prevalência do HIV, reafirma o maior grau de vulnerabilidade entre pessoas trans também naquele país, sendo que em 2012 o índice de prevalência em relação a população adulta em geral era de $0,4 \%$.

No Panamá, uma análise (146) feita pelo Banco Mundial em 2013 estimou um nível de prevalência de $10 \%$ entre a população de $\mathrm{HSH}$, na qual se insere a população trans, sendo que entre a população em geral a prevalência apresentava-se em torno de 0,9\% em 2012.

$\mathrm{O}$ estudo "HIV risk behaviors among male-to-female transgender persons of color in San Francisco" (147) apresenta uma análise importante a respeito das situações de prevalência e risco à infecção do HIV entre pessoas trans. A partir de pesquisa qualitativa com 332 participantes, o estudo compara os contextos de vulnerabilidade entre pessoas trans afro americanas, latinas e asiáticas que vivem em San Francisco, sendo: 112 afro americanas, 110 latinas e 110 asiáticas das Ilhas Pacíficas. Segundo o estudo, a estimativa de prevalência do HIV entre a população trans, em diferentes países e contextos, varia entre $11 \%$ a $78 \%$, a depender da região, da raça e da etnia.

Outros estudos realizados em San Francisco (147) e Los Angeles (148) demonstraram que a prevalência do HIV variou significativamente de acordo com raça/etnia. $\mathrm{O}$ grupo de afro americanas apresentou maior prevalência, que variava entre $44 \%$ a 63\%, seguido por latinas $(26 \%$ a $29 \%)$, brancas $(16 \%$ a $22 \%)$ e asiáticas (4\% a 27\%). Também tiveram influência para a soropositividade: status socioeconômico, anos de estudo, quantidade de parceiros sexuais ao longo da vida e o uso de drogas injetáveis. A exclusão social foi um componente comum observado no grupo de pessoas trans, por 
exemplo, mais de um terço das pessoas que participaram das pesquisas não puderam concluir o ensino médio e menos da metade das pessoas (49\%) tiveram habitação permanente nos últimos seis meses. Na mesma linha de outros dados acima apontados, o uso de preservativo variou de acordo com o tipo de parceria: casual, comercial ou parceiros estáveis. Entre os parceiros estáveis, o uso ou não do preservativo esteve associado com o uso de drogas antes da relação sexual. Já entre os parceiros casuais, o sexo anal sem preservativo foi associado ao status de HIV (positivo) e ao uso de drogas. Dentre as parcerias comerciais (profissionais do sexo), o uso ou não de preservativos foi fortemente associado à raça/etnia e à baixa renda.

O estudo demonstrou ainda que entre as entrevistadas um terço teve relações sexuais anais receptivas, tanto com parceiros afetivo/sexuais estáveis, quanto com parceiros casuais e comerciais. No caso dos parceiros estáveis, foi relatada uma menor frequência do uso de preservativos nas relações anais receptivas, em comparação com as relações envolvendo parceiros casuais e/ou comerciais. Além desses dados, vale destacar nas pesquisas: a associação entre sexo desprotegido, considerando todos os tipos de relação afetiva/sexual, e os efeitos do uso de drogas; pessoas que se declararam HIV positivos apresentaram propensão 3,8 vezes mais acentuada de envolvimento em práticas sexuais anais receptivas desprotegidas, com parceiros casuais soro discordantes; o nível de renda também influenciou o não uso de preservativos nas práticas de sexo anal receptivo desprotegido, as afro americanas tiveram 4,5 vezes mais relações desprotegidas em comparação com as não afro americanas, além de possuírem menor nível de renda. Por fim, as participantes deste estudo afirmaram que o uso de preservativo pode prejudicar o sentimento de intimidade e conexão com o/a parceiro/a nas relações estáveis.

O grupo das "trans asiáticas" apresentou menor prevalência para o HIV e relatou a ocorrência de menos sexo anal receptivo sem preservativo, bem como sob a influência dos efeitos de drogas. A pesquisa indica a possibilidade de existir uma forte ligação entre comportamentos de autocuidado e cuidado mútuo, com o fato deste grupo também ser o mais escolarizado e com maior renda.

Com o objetivo de qualificar as informações sobre a infecção pelo HIV e outras DST, também sobre os fatores de risco entre pessoas trans, o Centro de Investigação em Epidemiologia e Saúde da População da França, conduziu o estudo "Infection à VIH et 
IST dans la population 'trans': une revue critique de la littérature internacional " (128), constatando que fatores como a instabilidade social, estigma e discriminação, pertencimento a minorias étnicas, migração internacional e a insegurança relacionada ao trabalho sexual, figuram entre os principais riscos para o HIV dentre esta população.

A pesquisa aponta a necessidade de dimensionar os contextos de vulnerabilidade e as características sociais que incidem sobre a população de pessoas trans, tornando-as diferentemente vulneráveis à infecção e adoecimento em decorrência do HIV/AIDS. A relação entre exclusão social, exclusão escolar e a consequente limitação ao mercado de trabalho tem que ser considerada como um importante determinante para a maior prevalência do HIV/AIDS.

Outros fatores que importam são a migração internacional e/ou o pertencimento a minorias étnicas (tal como ser afro-americana nos EUA), entretanto, o fato de pertencer a uma minoria étnica não afeta uniformemente a prevalência do HIV, pois são diversos os fatores de risco aos quais os indivíduos estão expostos, conforme mencionado acima.

É importante observar que a pesquisa mostra taxas de prevalência de HIV altamente diferenciadas, de acordo com o local onde a pesquisa foi realizada, e, mais amplamente, relacionando-as ao contexto social e epidemiológico em que vivem. Embora os dados não apresentem um censo abrangente da proporção de pessoas ou da magnitude do problema em relação à epidemia geral, ainda permite inferir questões essenciais para o enfrentamento dos contextos de vulnerabilidades em que pessoas trans, a rigor, estão inseridas.

Outro estudo bastante importante para compreensão das questões estruturais, sociais e comportamentais que se relacionam com o HIV/AIDS foi desenvolvido pelos pesquisadores Herbst, Jacobs, et al. (149) nos EUA. O estudo intitulado "Estimating HIV prevalence and risk behaviors of transgender persons in the United States: a systematic review. Aids and Behav ${ }^{, 79}$ apresentou uma grande variação de prevalência do HIV (auto relatada): variando entre 3,4 \% de infecções por ano em Los Angeles até $50 \%$ em New York, dentre mulheres transexuais afro-americanas.

\footnotetext{
${ }^{79}$ A pesquisa foi baseada em uma revisão sistemática de 29 estudos de diferentes estados dos Estados Unidos entre o período de 1990 a 2003. Entre os estudos selecionados, 22 deles apresentam taxas de prevalência de HIV, sendo que em quatros dos 22 estudos, as taxas de HIV foram determinadas por meio de testes sorológicos e os demais estudos foram auto relatados.
} 
Em poucos estudos as taxas de HIV foram determinadas por meio de testes sorológicos, de forma que a maior parte foram auto relatados. Mesmo considerando possíveis limitações metodológicas ${ }^{80}$, a prevalência média de infecção para o HIV em pessoas trans é alta em comparação com a população em geral: $27,7 \%$ é a prevalência média determinada por meio de testes sorológicos e 11,8\% é a prevalência auto-inferida.

O estudo (149) sugere que muitas pessoas trans que participaram destas pesquisas podem desconhecer seu estado sorológico. Independente disto, os dados indicam alta prevalência global de HIV e outras DST, com destaque para a sífilis entre pessoas trans, em comparação com outros grupos populacionais. Entretanto, a pesquisa também apresenta uma variação na prevalência de acordo com os contextos de vulnerabilidades em que estão inseridas, o que reforça a importância de se mapear também os fatores de proteção e oportunidades favoráveis à saúde integral das pessoas trans.

O estudo etnográfico "Sex Workers, Fem Queens, and Cross-Dressers: Differential Marginalization and HIV Vulnerabilities Among Three Ethno cultural Male-to-Female Transgender Communities in New York City" (150), desenvolvido em New York, compara três grupos de pessoas trans trabalhadoras do sexo: afro-americanas, latinas/asiáticas e brancas. Demonstra que o grau de vulnerabilidade para a infecção do HIV/AIDS e outras DST depende de um entrelaçamento de fatores, tais como: ser ou não imigrante ilegal, trabalhar nas ruas ou em hotéis, o nível de dependência econômica, que possibilita, por exemplo, a seleção dos clientes que as mantém relativamente seguras. E, mesmo levando em conta as diferenças existentes entre os grupos, o texto ressalta que em todos eles é necessário compreender as correlações entre trabalho sexual e prevalência do HIV entre pessoas trans.

A relação entre trabalho sexual e aids também foi descrita no estudo "Sex work and HIV status among transgender women: systematic review and meta-analysis" (151), realizada pela Universidade de Oxford em 2008, onde foram identificados 25 estudos com 6405 participantes. O estudo aponta uma prevalência global média de 27,3\% em mulheres transexuais profissionais do sexo, e 14,7\% em mulheres transexuais não engajadas no trabalho sexual. Tais dados foram comparados àqueles referentes aos

\footnotetext{
${ }^{80} \mathrm{Em}$ algumas pesquisas não foi possível verificar na análise metodológica se as participantes que frequentam os centros de saúde (no qual os dados foram sistematizados) o faziam em razão de estar acometidos por alguma infecção. Neste caso, poderia haver uma distorção de resultados em relação as altas taxas de prevalência do HIV.
} 
homens e mulheres (biológicas) profissionais do sexo destes mesmos países, resultando nos seguintes dados de prevalência: 15,1\% entre homens (biológicos) profissionais do sexo e $4,5 \%$ em mulheres profissionais do sexo.

Outro estudo, menos recente, que aborda a correlação entre aids, profissionais do sexo, uso de drogas e pessoas trans, "HIV infection among foreign people involved in HIVrelated risk activities and attending an HIV reference centre in Rome: The possible role of counselling in reducing risk behaviour" (152), realizado com 528 estrangeiros que utilizavam um centro de testes e aconselhamento para HIV e uso de drogas em Roma, demonstrou que a maior parte dos participantes eram pessoas trans da América do Sul, advindos do Brasil e da Colômbia (40\%) e do Norte da África (37,5\%), dos quais a grande maioria era trabalhadora sexual. A prevalência geral do HIV foi alta $(21,6 \%)$, variando por nacionalidade de $5,1 \%$ entre os norte-africanos, para $68,3 \%$ entre as transexuais brasileiras. O estudo aponta, em conformidade com as demais pesquisas citadas, a necessidade de facilitar o acesso aos cuidados e tratamento para pessoas marginalizadas.

Corroborando com os achados de Giami e Le Bail (128) citados anteriormente, é possível inferir que a prevalência varia significativamente a depender de vários fatores, como profissão, nacionalidade, origem e cor de pele. Na literatura internacional, apontase a forte correlação entre trabalho sexual e a prevalência do HIV, ressaltando também as situações de migração irregular, uso de drogas, marcadamente pelo compartilhamento de seringas. Fazer sexo com múltiplos parceiros - de diferentes identidades, gênero e orientação sexual - também foi identificado como fator de risco para a infecção do $\mathrm{HIV}^{81 .}$

As conclusões dos estudos indicam que as "pessoas trans" estão submetidas a conjunções de particular vulnerabilidades para a infecção e o adoecimento pelo HIV/AIDS, estando expostas a múltiplas formas de violência, dentre as quais, destacase: violência doméstica e sexual, discriminação em espaços públicos, isolamento social,

\footnotetext{
${ }^{81}$ Maiores informaçōes consultar: The Role of Male Sexuals Partners in HIV Infection Among Male-toFemale Transgendered Individuals. (196). "Men Who Have Sex with Transgender Women: Challenges to Category-based HIV Prevention" (197). "Latino Men's Sexual Behavior with Transgender Persons. Archives of Sexual Behavior" (198). Infection à VIH et IST dans la population "trans": une revue critique de la littérature internacional (128).
} 
violência policial, discriminação no emprego, barreiras no acesso a serviços públicos e insumos de prevenção. 


\section{RESPOSTAS GOVERNAMENTAIS ÀS DEMANDAS DE SAÚDE DAS TRAVESTIS}

\subsection{BREVE HISTÓRICO DAS POLÍTICAS NACIONAIS DE SAÚDE} RELACIONADAS ÀS TRAVESTIS

A despeito das conquistas e dos avanços pertinentes às políticas públicas de saúde para travestis, ainda há problemas estruturais que precisam ser superados se desejamos afirmar a universalização do acesso às ações de saúde propostas pelo SUS.

De acordo com Mello, L. et. al. (153) as política de saúde contemplam um leque de iniciativas voltadas à formulação, implementação e avaliação de programas e ações no âmbito da atenção à saúde que afetam a saúde humana e o ambiente, neste sentido o "Programa Brasil sem Homofobia - Programa de Combate à Violência e à Discriminação contra Gays. Lésbicas, Transgêneros e Bissexuais (GLTB) e de Promoção da Cidadania Homossexual" ${ }^{\prime 2}$, lançado no ano de 2004, pode ser considerado um marco nas iniciativas governamentais voltadas à promoção da cidadania desta população. As ações propostas no programa envolveram diferentes Ministérios com objetivo de promover a cidadania de gays, lésbicas, travestis, transgêneros e bissexuais a partir da equiparação de direitos e do combate à violência e à discriminação homofóbica. Mesmo considerando o progresso desta iniciativa, vale destacar que as ações propostas para a população de travestis, a época, desconsiderando as idiossincrasias e contextos envolvidos, pouco se diferenciavam das ações para lésbicas, gays, transexuais e transgêneros, como se verá a seguir, esta diferenciação pode ser notada mais evidente a partir de ano de 2008, marcado pelas Conferencias Nacional e Estaduais LGBT.

\footnotetext{
${ }^{82}$ Programa "Brasil sem homofobia: programa de combate à violência e à discriminação contra GLTB e de promoção da cidadania homossexual". Este programa teve como proposta a inclusão da perspectiva da não-discriminação por orientação sexual e de promoção dos direitos humanos de gays, lésbicas, transgêneros e bissexuais, nas políticas públicas e estratégias do Governo Federal, a serem implantadas (parcial ou integralmente) por seus diferentes Ministérios e Secretarias.
} 
No ano de 2006 o Ministério da Saúde publicou a "Carta dos Direitos dos Usuários da Saúde ${ }^{, 83}$, aprovada por meio da Portaria $\mathrm{n}^{\mathrm{o}} 675 / 2006^{84}$. A proposta da carta é que sirva de instrumento para a garantia do acesso universal e igualitário às ações e serviços para promoção, proteção e recuperação da saúde, marcadamente em duas direções: reconhece o direito das pessoas a atendimento humanizado, acolhedor, livre de qualquer discriminação, restrição ou negação em razão de qualquer fator, como idade, raça, cor, etnia, religião, orientação sexual, identidade de gênero, condições econômicas ou sociais, estado de saúde, de anomalia, patologia ou deficiência; por sua vez, garante, em todo documento do usuário/usuária, um campo para se registrar o nome social, independentemente do registro civil, sendo assegurado desta forma o uso do nome de preferência do cidadão/cidadã.

No que se refere às estratégias políticas para LGBT, outra importante iniciativa ocorreu em 2008, quando o governo brasileiro propôs um amplo debate com a sociedade civil por meio das “Conferências Nacional e Estaduais LGBT", nas quais foram estabelecidas as diretrizes para o Plano Nacional e Planos Estaduais de promoção da cidadania e direitos humanos LGBT.

Em maio de 2009 é lançado o Plano Nacional de Promoção da Cidadania e Direitos Humanos de $L G B T^{85}$, com objetivo de articular a implementação de ações relacionadas à população LGBT entre os diferentes ministérios. Também em 2009 é criada, pelo Decreto $6.980^{86}$, a "Coordenação-Geral de Promoção dos Direitos de Lésbicas, Gays,

\footnotetext{
${ }^{83}$ A Carta dos Direitos dos Usuários da Saúde foi aprovada pelo Conselho Nacional de Saúde (CNS) três anos depois, na reunião ordinária realizada em 17 de junho de 2009. Para maiores informações, sugere-se consultar: $\quad$ http://bvsms.saude.gov.br/bvs/publicacoes/carta_direitos_usuarios_saude_ilustrada.pdf Acessado em 10/10/2014.

${ }^{84}$ Ministério da Saúde (BR). Portaria n ${ }^{\circ}$ 675/GM, de 30 de março de 2006. Aprova Carta dos Direitos dos Usuários da Saúde, que consolida os direitos e deveres do exercício da cidadania na saúde em todo o país. Diário Oficial da União, Brasília, DF, 31 mar. 2006. Seção I, p. 131.

${ }^{85}$ Disponível em http://pt.slideshare.net/juarezhc/plano-nacional-de-lgbt. Acessado em 20 de outubro de 2014.

${ }^{86}$ Decreto $^{\circ}$ 6.980, de 13 de outubro de 2009. Aprova a Estrutura Regimental e o Quadro Demonstrativo dos Cargos em Comissão da Secretaria Especial dos Direitos Humanos da Presidência da República, dispõe sobre o remanejamento de cargos em comissão do Grupo-Direção e Assessoramento Superiores DAS, altera o Anexo II ao Decreto no 6.188, de 17 de agosto de 2007, que aprova a Estrutura Regimental e o Quadro Demonstrativo dos Cargos em Comissão do Gabinete Pessoal do Presidente da República, e dá outras providências. Disponível em: http://www.planalto.gov.br/ccivil_03/_Ato20072010/2009/Decreto/D6980.htm Acessado em 12/10/2014.
} 
Bissexuais, Travestis e Transexuais”, com a finalidade de coordenar a elaboração e implementação dos planos, programas e projetos relacionados aos direitos de Lésbicas, Gays, Bissexuais, Travestis e Transexuais em âmbito nacional.

O Decreto $\mathrm{n}^{\mathbf{o}} 7.388^{87}$ de 09/12/2010 instituiu o Conselho Nacional de Combate a Discriminação e Promoção dos Direitos de LGBT, que tem por finalidade formular e propor diretrizes de ação governamental, em âmbito nacional, voltadas para o combate à discriminação e para a promoção e defesa dos direitos de Lésbicas, Gays, Bissexuais, Travestis e Transexuais. Neste mesmo ano, as servidoras travestis e transexuais do poder executivo federal conquistam o direito do uso do nome social no crachá, no email funcional, nas listas de ramais, nos cadastros e nas comunicações internas.

Em dezembro de 2011 o Ministério da Saúde lançou a Portaria ${ }^{\circ} 2.836^{88}$, que instituiu no âmbito do SUS a Política Nacional de Saúde Integral de Lésbicas, Gays, Bissexuais, Travestis e Transexuais. Pactuada pela Comissão Intergestores Tripartite $(\mathrm{CIT})^{89}$, a política define diretrizes que orientam para a atenção integral ao público LGBT, incluindo as especificidades da população de travestis, consideradas como graves problemas de saúde pública, tais como: a epidemia de aids, o uso do silicone industrial, a hormonioterapia e a saúde mental. Neste sentido, a política aponta os objetivos, responsabilidades e ações a serem implementadas em todas as esferas de gestão do SUS.

\footnotetext{
${ }^{87}$ Decreto $n^{\circ} 7.388$, de 9 de dezembro de 2010. Dispõe sobre a composição, estruturação, competências e funcionamento do Conselho Nacional de Combate à Discriminação - CNCD. Disponível em: http://www.planalto.gov.br/ccivil_03/_Ato2007-2010/2010/Decreto/D7388.htm Acessado em 10/10/2014.

${ }^{88}$ Portaria ${ }^{\circ}$ 2.836, de 01/12/2011 - Institui, no âmbito do Sistema Único de Saúde (SUS), a Política Nacional de Saúde Integral de Lésbicas, Gays, Bissexuais, Travestis e Transexuais (Política Nacional de Saúde Integral LGBT).

${ }^{89}$ A Comissão Intergestores Tripartite (CIT) é constituída em nível federal por representantes (5) do Ministério da Saúde, do Conass e do Conasems, cuja representação de estados e municípios é regional, sendo um representante para cada região do País. Na CIT são definidas diretrizes, estratégias, programas, projetos e alocação de recursos do SUS. Disponível em: http://devsus20anos.datasus.gov.br/SUS20ANOS/index.php?area=030303. Acessado em 10/10/2014.
} 
Em 2012, o Ministério da Saúde lança o "Cartão SUS", cuja normativa ${ }^{90}$ garante a utilização do nome social de travestis e transexuais nos serviços de saúde, legitimandose o direito à identidade de gênero desta população e a necessidade de promoção do acesso à rede pública de saúde. Neste sentido, segundo o Secretário de Vigilância em Saúde, Jarbas Barbosa:

Um dos grandes desafios do Sistema Único de Saúde atualmente é combinar as políticas universais, que atendem a toda a população, com as políticas que precisam quebrar barreiras sociais, culturais, de preconceito. Se os serviços de saúde não têm estratégias que permitam o adequado acolhimento de travestis e transexuais, esses grupos se tornarão cada vez mais vulneráveis. Essa é uma questão de saúde pública e a primeira barreira a ser transposta é a de permitir que essas pessoas sejam atendidas nas unidades de saúde pelo nome que desejam (154).

Sobre este tema, a travesti e conselheira nacional de saúde, Fernanda Benvenutty (2014) afirma que “... quando uma travesti deixa de procurar o serviço de saúde, normalmente é porque já antecipa a frustração de ser tratada pelo seu nome de registro" (154).

Em 2013, reforçando as comemorações do "Dia da Visibilidade Trans", o Ministério da Saúde, em parceria com a Secretaria de Direitos Humanos da Presidência da República, lançou a campanha de combate à violência contra travestis e transexuais: "Travesti que se cuida, denuncia". A campanha tinha como principal objetivo divulgar o "Disque 100 "91 para a população de travestis e transexuais, entendendo ser esta uma possibilidade de denunciar as violências cotidianas sofridas por este segmento. $O$ material era seguinte:

\footnotetext{
${ }^{90}$ Portaria no 940, de 28/04/2011 - Regulamento Sistema Cartão Nacional de Saúde (Sistema Cartão). Disponível em: http://bvsms.saude.gov.br/bvs/saudelegis/gm/2011/prt0940_28_04_2011.html Acessado em 10/10/2014.

${ }^{91}$ O Disque Direitos Humanos, ou Disque 100, é um serviço vinculado a Secretaria de Direitos Humanos da Presidência da República (SDH/PR). Trata-se de um canal de comunicação da sociedade com o poder público, que possibilita conhecer e avaliar a dimensão da violência contra os direitos humanos e o sistema de proteção, bem como orientar a elaboração de políticas públicas. Para maiores informações: http://www.crianca.mppr.mp.br/modules/conteudo/conteudo.php?conteudo=3 Acessado em 20/10/2014.
} 


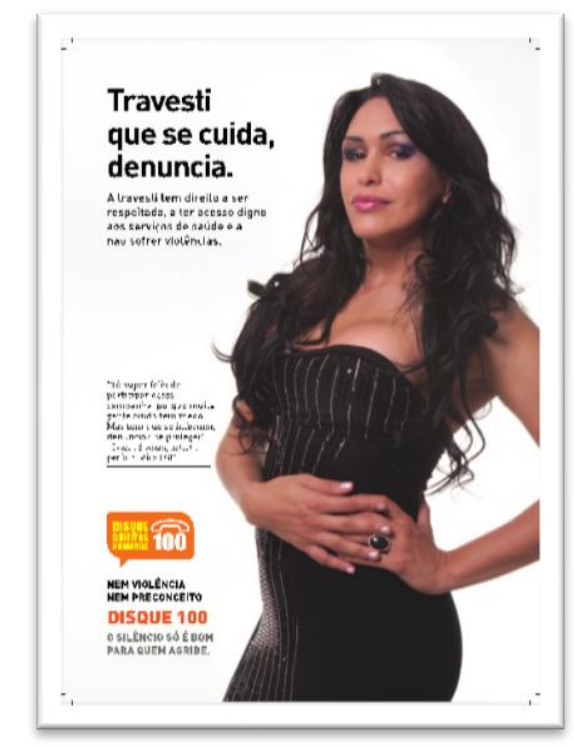

Figura 07: cartazes referentes à divulgação do Disque 100. Fonte Ministério da Saúde

Neste mesmo ano, no mês de novembro, o Ministério da Saúde redefine e amplia o Processo Transexualizador no SUS, por meio da Portaria $n^{o} 2.803^{92}$, que garante o estabelecimento de linha de cuidado e ampliação da atenção à saúde, considerando a integralidade, desde a atenção primária até a alta complexidade, a inclusão de procedimentos como a hormonioterapia, sem indicação para a cirurgia de transgenitalização e o atendimento à população de mulheres transexuais, bem como as travestis e homens transexuais. Abaixo o material produzido sobre o direito ao tratamento pelo nome social:

\footnotetext{
${ }^{92}$ Portaria $\mathrm{n}^{\mathrm{o}} 2.803$, de 19 de novembro de 2013. Redefine e amplia o Processo Transexualizador no Sistema Único de Saúde (SUS). Disponível em: http://bvsms.saude.gov.br/bvs/saudelegis/gm/2013/prt2803_19_11_2013.html Acessado em 10/10/2014.
} 


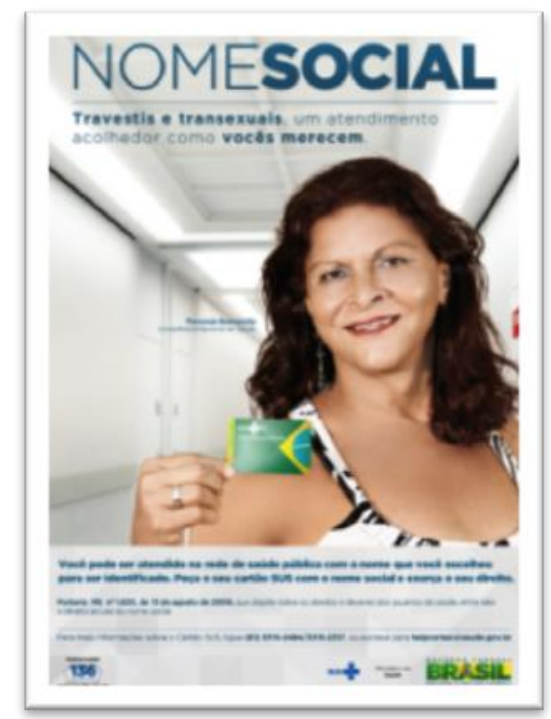

Figura 08: cartaz referente ao direito ao tratamento pelo nome social. Fonte Ministério da Saúde

Em 2014, a Secretária de Comunicação e Assuntos Internacionais da ANTRA, Keila Simpson, recebeu da Presidenta da República Dilma Rousseff o "Prêmio Direitos Humanos", que constitui a maior homenagem do governo brasileiro, pelo reconhecimento da sua atuação em defesa da comunidade travesti e transexual, na categoria "Garantia dos Direitos da População LGBT". Para Keila, atualmente a principal bandeira de lutas do movimento de travestis e transexuais é o respeito ao nome civil, por meio do que exigem ser reconhecidas e reconhecidos segundo o nome que escolheram. Além do nome, a ativista destaca mais uma vez a visibilidade positiva e o combate à transfobia como pautas principais do movimento trans para 2014:

A visibilidade positiva é trazer a mensagem que queremos, ou seja, sermos vistas e compreendidas como somos, sem falsos moralismos ou coisa que o valham, pois quando essa população é visibilizada, quase tão somente mostram o lado negativo da história. Protestaremos também contra a violência que impera na nossa população, tanto a letal como a social, pois elas acabam impedindo que essas pessoas sigam suas vidas e as afastam dos serviços básicos, como acesso à saúde, emprego e educação (155).

Desta forma, destacam-se por um lado os progressos nas políticas públicas de enfrentamento à homofobia/transfobia, avançando na promoção da cidadania LGBT, bem como na deferência aos princípios de equidade, integralidade e participação do SUS; por outro vértice, é igualmente inegável a resistência a tais avanços por parte de setores conservadores, que oferecem oposição ao exercício pleno dos direitos sexuais, 
alguns destes setores contam com representatividade no poder legislativo federal, chegando mesmo a contar com candidatura a Presidência da República ${ }^{93}$.

Como exemplo desta resistência, vale lembrar também o episódio relacionado ao Projeto de Lei da Câmara n. ${ }^{\circ} 122 / 06^{94}$, que objetivava criminalizar a discriminação, os discursos de ódio, as ofensas (individuais e/ou coletivas) baseadas unicamente na orientação sexual e na identidade de gênero de um indivíduo. Embora a lei brasileira já contemple penalidades contra quem discrimina em razão de cor, etnia, procedência nacional e religião (Lei $7716 / 89^{95}$, por exemplo), o PLC 122, após 12 anos de tramitação no Congresso Nacional, foi apensado à proposta de reforma do Código Penal (PLS 236/2012), sob argumento de que tal Código trata de assuntos correlatos, ao tipificar criminalmente a intolerância, o racismo e todo tipo de violência.

Em outras palavras, o crime em razão da homofobia não será mais discutido isoladamente, mas incorporado às discussões do Código Penal, o que pode enfraquecer o necessário debate sobre este tipo de crime pela falta de respaldo jurídico, uma vez que, conforme observado por Rios R. e Carrara S, Vianna ABR (157), a punição nos casos de outros tipos de preconceitos, como o racismo, incide de forma muito mais rápida devido ao suporte jurídico, o que não acontece nos casos de homo/transfobia ainda percebidos pela população em geral com certa naturalidade.

Ainda para ilustrar tal situação, destaque-se que a ocorrência de homicídios cometidos contra travestis são apurados com menor empenho por agentes da segurança pública e

\footnotetext{
${ }^{93}$ No debate dos candidatos à Presidência da República, pleito 2014, realizado no dia 28/09/2014 pela TV Record, o candidato Levy Fidelix (PRTB), dentre outros impropérios homofóbicos, associou a homossexualidade com pedofilia, declarou que gays precisam de atendimento psicológico longe do convívio social, afirmou que a sociedade será prejudicada porque aparelho excretor não reproduz e ainda insinuou que essa minoria precisa ser "enfrentada". Disponível em: http://eleicoes.uol.com.br/2014/noticias/2014/09/29/levy-associa-homossexuais-a-pedofilia-e-pregaenfrentamento-a-gays.htm. Acessado em 03/11/2014.

${ }^{94}$ Projeto de Lei da Câmara no 122/2006 (PLC 122/2006), popularmente conhecido como PL 122, é um projeto de lei apresentado pela então deputada Iara Bernardi. Propunha, além da penalização criminal, também punições de natureza civil para o preconceito homofóbico, como a perda do cargo para o servidor público, a inabilitação para contratos junto à administração pública, a proibição de acesso a crédito de bancos oficiais e a vedação de benefícios tributários. Informações disponíveis em: http://www.plc122.com.br/sobre-site-plc122/\#axzz3GoA4x5ZY Acessado em 10/10/2014.
}

\footnotetext{
${ }^{95}$ Lei $\mathrm{n}^{\circ}$ 7.716, de 5 de janeiro de 1989. Define os crimes resultantes de preconceito de raça ou de cor.
} Disponível em: http://www.planalto.gov.br/ccivil_03/leis/17716.htm Acessado em 10/10/2014. 
policias, tendo como desfecho, na maior parte das vezes, o seu arquivamento, como informam Carrara S, Vianna ABR (157). Conforme Duarte (158), é no impedimento para a criminalização da homofobia que se veicula com transparência uma concepção moralista e pecaminosa às práticas sexuais e impõe-se uma visão religiosa ao Estado, que deveria primar pela sua laicidade e por um governo para todos (as).

\subsection{ENTLAIDS E OUTRAS RESPOSTAS PARA AS TRAVESTIS NO CAMPO DA PREVENÇÃO DO HIV/AIDS}

Neste estudo interessa sobremaneira a visualização das respostas para as travestis no campo da prevenção do HIV/AIDS, desta forma, procurou-se elencar as principais respostas governamentais para esta população, porém a escassez de estudos avaliativos acerca dos resultados das estratégias e práticas de prevenção, não permitem determinar efetivamente quais destes programas e/ou estratégias atingiram seu objetivo, conforme Russell (159).

Em face às demandas relacionadas ao campo da aids abordadas ao longe deste trabalho, o Programa de aids do governo brasileiro, desde sua criação no ano de 1985, tem mobilizado recursos e apoios governamentais para realização de intervenções de prevenção e controle da epidemia, em especial para aqueles considerados como "pessoas em situação de maior vulnerabilidade e risco".

Uma importante estratégia para as travestis é o "Encontro Nacional de Travestis e Transexuais na Luta contra a Aids (ENTLAIDS)", o maior evento político com abrangência nacional realizado pelo movimento social de travestis e transexuais em parceria com o governo. Organizado pela primeira vez no ano de 1992 na cidade do Rio de Janeiro, por iniciativa da ativista Jovanna Baby ${ }^{96}$, os encontros buscam responder à necessidade de enfrentar a epidemia de aids e, sobretudo, fortalecer a militância e a formação de uma consciência política capaz de fazer frente ao estigma e a exclusão social, conforme Peres (160). As reivindicações propostas nos ENTLAIDS relacionamse com os macro determinantes de saúde e doença, e neste sentido o tema "aids" proporcionou ao movimento de pessoas trans uma oportunidade de organização e

\footnotetext{
${ }^{96}$ A travesti e ativista Jovanna Baby então presidente da ANTRA - Articulação Nacional de Travestis e Transexuais.
} 
fortalecimento da sua militância política. Em termos de políticas públicas, marca-se a importância da participação da sociedade civil, como prevista nos princípios organizativos do SUS, uma vez que desempenhou e ainda desempenha um papel fundamental na resposta da epidemia da aids. Neste contexto, o "Relatório Final do XIX ENTLAIDS" (Brasília/2012), aponta:

O ENTLAIDS é um espaço de discussão nacional para a abordagem de questões relacionadas à saúde integral, à prevenção das DST/HIV e Hepatites Virais e aos direitos humanos, sendo seus eixos programáticos focalizados na exposição de informações atualizadas, na identificação de prioridades do coletivo de representantes da população Trans do país e no intercâmbio de experiências desenvolvidas por lideranças e/ou instituições Trans. Os resultados dos trabalhos desenvolvidos no evento são base para a tomada de decisão coletiva sobre diferentes temas e/ou estratégias, subsidiando também o fortalecimento técnico das principais lideranças Trans do país e, consequentemente, o aprimoramento da atuação e trajetória deste movimento. O caráter nacional desse Encontro estimula a realização de atividades paralelas envolvendo as principais lideranças Trans do país em questões multidisciplinares, tais como o fortalecimento e/ou reestruturação da rede Trans; a identificação de lideranças Trans para representar o movimento em diferentes instâncias consultivas e/ou deliberativas; e, resoluções e/ou planejamento de atividades da diretoria da ANTRA, entre outros (170).

Desde a primeira edição do ENTLAIDS até a última, realizada em 2013, os recursos financeiros para sua realização foram viabilizados por meio de editais públicos de seleção de projetos, oriundos do Departamento de DST/Aids e Hepatites Virais (DDAH) do Ministério da Saúde (MS). Os temas e subtemas ${ }^{97}$ abordados nestes

\footnotetext{
${ }^{97}$ Parte do registro dos nomes dos ENTLAIDS foi resgatado pelos autores Alessandro Soares Silva e Renato Barboza no artigo intitulado "Exclusão social e consciência política: luta e militância de transgêneros no ENTLAIDS", no ano de 2007. Entretanto, segundo os Autores, não foi possível resgatar todos os nomes e temas tratados nos eventos, pois não há sistematização disponível. Mesmo assim, os registros existentes, possibilitaram visibilizar que os ENTLAIDS tiveram as seguintes bandeiras: "Cidadania não tem roupa certa"; "Cidadania plena para gays e lésbicas"; "Conquistando novos espaços: aids, contrato social entre homossexuais, uso de silicone, mercado de trabalho, religião e violência"; "Abrindo novos caminhos"; "Unidas/os construindo uma nova realidade social: políticas públicas de aids; religião e homofobia, violência policial e Direitos Humanos"; "Unid@s pelo direito de ser"; "Politicas Públicas de Saúde e Cidadania para travestis liberad@s: direito à cidadania livre de estereótipos (ser travesti não implica necessariamente a prática da prostituição), participação nas políticas públicas, combate à exclusão social, reivindicações pelo tratamento humanizado nos serviços de saúde e nas ações de segurança pública"; "Direitos Humanos, promoção à saúde, prevenção, sustentabilidade, sexualidade e avanços do movimento trans nacional: direitos humanos, resgate da cidadania e políticas de prevenção às DST e AIDS"; "Políticas Públicas na Diversidade"; "Um Brasil
} 
encontros, no período de 1993 a 2013, refletem a agenda dos Direitos Humanos e as prioridades deste movimento em relação à saúde. Nos eventos em que participei ${ }^{98}$ 2011, 2012 e 2013 - pude constatar que, conforme descrito pelos pesquisadores Teixeira (39), Peres e Toledo (117), apesar do objetivo central dos ENTLAIDS ser a aids, que se destaca já no nome do evento, desde sua primeira edição os debates concentram-se em torno da insuficiência na garantia dos direitos humanos, onde o tema "aids" é apenas coadjuvante, uma entre tantas outras consequências das iniquidades e injustiças sociais. As reflexões propostas nestes encontros têm problematizado a efetividade do SUS no que se refere ao acesso de travestis e transexuais às políticas públicas, aos bens e serviços sociais, bem como a baixa capacidade na melhoria das condições sócio-político-culturais dessa população. Por outro lado, questões relacionadas à vivência com o HIV são pouco discutidas, conforme explicitado pela pesquisadora Flavia Teixeira (104):

Temos observado, de 2006 a 2013, as dificuldades enfrentadas pelas travestis que se identificam como soropositivas de pautarem temáticas sobre suas vivências, necessidades e expectativas durante os ENTLAIDS.

A menor visibilidade em torno da vivência da soropositividade entre as travestis possivelmente reflita o temor pela culpabilização/responsabilização individualizada relacionada à infecção pelo HIV/AIDS, no qual se desconsidera que os fatores sociais, culturais e políticos são geradores de desigualdades e exclusão social, estando na base da suscetibilidade à infecção pelo vírus HIV, na linha do quanto proposto por Mann, Tarantola e Netter (94).

Desta forma, mesmo considerando os ENTLAIDS uma estratégia importante para o fortalecimento do movimento de travestis e transexuais, sobretudo em relação à agenda dos direitos humanos, a emergência conjuntural da epidemia de aids entre pessoas trans demanda uma reflexão sobre o alcance de tais estratégias. Por exemplo, as

de Todos é um Brasil sem Transfobia: tráfico de Seres Humanos e Cafetinagem, transgêneros brasileiras na Europa, prostituição Infantil de adolescentes transgêneros e saúde Integral"; "Cidadania: Um Direito de Tod@s: transgênero, inclusão social, serviços públicos, justiça e legislação e participação na mídia; "Da Transfobia à Cidadania", "Da FORMAÇÃO à PREVENÇÃO - Estratégias para o fortalecimento do exercício da Cidadania da População Trans Brasileira".

${ }^{98}$ Nos anos de 2011, 2012 e 2013 tive a oportunidade de participar dos ENTLAIDS como consultora técnica do Departamento de DST, HIV, Aids e Hepatites Virais do Ministério da Saúde. 
recomendações propostas nos ENTLAIDS poderiam contribuir com a tomada de decisões políticas, definição de prioridades e reorientação de práticas, porque revelam a vivência das próprias travestis e dos homens e mulheres transexuais no campo da aids; todavia, o desconhecimento sobre o conteúdo destas recomendações por parte dos gestores públicos, aliado à precariedade de informações sistematizadas, indica uma lacuna entre o propósito das recomendações e as possibilidades reais de absorvê-las como instrumentos políticos pertinentes.

Para que encontros como os ENTLAIDS possam eventualmente impactar na qualificação das políticas de prevenção no campo do HIV/AIDS é indispensável que suas proposições sejam absorvidas pela gestão pública como uma espécie de ferramenta de tradução das demandas e oferta de soluções para os diversos problemas e desafios relacionados à saúde das travestis, mesmo porque, de acordo com Carvalho (171), "na saúde há um mundo de questões a serem resolvidas e de problemas esperando boas ideias e saídas".

Neste sentido, embora a inserção de ativistas "trans" nos diferentes espaços de construções políticas não assegure por si só políticas equitativas, sua participação é essencial, sem ela a singularidade se suas vivências e a concretude de suas necessidades cotidianas ficarão ainda mais invisibilizadas com reflexo direto sua saúde, em especial, no risco e nas vulnerabilidades em relação ao HIV/AIDS.

Ainda tratando das respostas governamentais, além do apoio aos ENTLAIDS, vale notar que desde 2006, com a implementação do Sistema de Monitoramento de Projetos $(\mathrm{SIMOP})^{99}$ pelo Departamento DST/AIDS/HV, é possível verificar que alguns recursos para a população de travestis foram investidos por meio de projetos estratégicos e editais públicos envolvendo uma série de iniciativas, com destaque para a realização de eventos, paradas do orgulho LGBT e pesquisas ${ }^{100}$, ações que, na maioria das vezes,

\footnotetext{
${ }^{99}$ Sistema de Monitoramento de Projetos (SIMOP): Sistema desenvolvido para controlar e monitorar a implementação de subprojetos executados pelas entidades implementadoras descentralizadas. Suas principais funções são: a) Controle da implementação de subprojetos no âmbito da coordenação do Departamento; b) Controle de repasses de recursos das agências internacionais para OSC e outras OG; c) Controle e verificação de prestações de contas recebidas das OSC executoras, por meio de relatórios periódicos gerados pelo sistema. Disponível em www.aid.gov.br. Acessado em 12 de dezembro de 2013.

${ }^{100}$ Em relação às estratégias identificadas a partir do SIMOP para travestis, é possível identificar alguns projetos: "Seminários sobre Direitos Humanos e Cidadania para travestis e transexuais"; os "Encontro
} 
foram realizadas em parceria com a sociedade civil e em alguns casos com as universidades. De acordo com os dados do SIMOP, no período de 2006 a 2013 foram realizados 85 projetos voltados para a população de travestis e transexuais ${ }^{101}$, com um custo total no valor de $\mathrm{R} \$ 3.399 .359,77$. Destas iniciativas, 47 projetos se relacionavam às Paradas de Orgulho LGBT (R\$ 742.327.21,04), os demais relacionavam-se à pesquisas ( $\mathrm{R} \$ 347.140,41)$, eventos ( $\mathrm{R} \$ 783.827,72)$, Projetos Estratégicos ( $\mathrm{R} \$$ 567.871.94,01) e Assessoria Jurídica (R $\$ 140.347,50)$.

Em 2009, o Departamento de DST, Aids e Hepatites Virais lançou um edital através do qual a Associação Pact do Brasil, em parceria com o movimento nacional das travestis e transexuais, aprovou o projeto "Transpondo Barreiras: Rede Tulipa Para Saúde, Cidadania e Prevenção das DST/Aids", que promoveu a articulação de diferentes organizações não governamentais com atuação junto às travestis em cinco regiões do país.

Em 2013, destaca-se o projeto "Vozes Para a Transformação - Região Centro-Oeste e Região Sul", que objetivou a ampliação da cobertura, qualificação de ações de prevenção das DST/HIV voltadas para travestis. Neste mesmo ano foram aportados recursos para a pesquisa intitulada "Vulnerabilidades, demandas de saúde e acesso a serviços da população de travestis e transexuais do estado de São Paulo", realizada pela Faculdade de Ciências Médicas da Santa Casa de São Paulo (FCMSCSP), Fundação Arnaldo Vieira de Carvalho (172). A pesquisa versa sobre os obstáculos no acesso aos cuidados de saúde da população de travestis e transexuais, indicando dificuldades no diálogo destes grupos com os serviços de saúde, o que resulta em sua baixa inserção nos serviços e na baixa adesão aos tratamentos, no que concerne à atenção básica e aos cuidados mais especializados, como o uso de hormônios e a cirurgia de redesignação sexual. Por fim, ainda neste ano surge o Projeto "Viva Melhor Sabendo", cujo objetivo é ampliar a testagem voluntária e oportuna do HIV para pessoas em contextos de maior vulnerabilidade, com a utilização de teste rápido de

Regionais de Travestis, Transexuais e Transgêneros"; "ENTLAIDS - Encontro Nacional de Travestis e Transexuais que atuam na Luta e Prevenção das DST/HIV/Aids”.

${ }^{101}$ Os dados foram retirados do SIMOP, entre o período de 2006 a 2013, a partir das palavras chaves: travestis, transexuais e LGBT. Entretanto, é possível que recursos destinados às travestis e transexuais tenham sido classificados em outras categorias, como homossexuais e HSH, desta forma podem não ser exatas as informações sobre recursos e projetos aprovados para este público 
fluido oral ${ }^{102}$. Para esta iniciativa, o Departamento DST/HIV/HV estabeleceu parceria com nove OSC com atuação e experiência junto ao público de travestis e transexuais para realização de testagem a partir da metodologia de "educação entre pares" 103 .

Em relação as estratégias descritas acima, vale observar que entre os anos de 2006 a 2012, objetivaram prioritariamente responder ao estigma que sempre esteve no centro da luta contra a epidemia, fomentando assim a mobilização e a auto-organização de ativistas e movimentos sociais através de ações de advocacy, defesa de direitos humanos, desenvolvimento institucional e ações de prevenção ao HIV/AIDS. A proposic $\square$ ão do conceito de vulnerabilidade, apresentada anteriormente, foi também uma estratégia discursiva para enfrentar a dupla estigmatizac $\square$ ão de grupos já estigmatizados, em especial dos gays, travestis, profissionais do sexo e usuários de drogas. Após este período é possível constatar uma maior focalização nas estratégias biomédicas apresentadas anteriormente, como a introduc $\square$ ão da profilaxia medicamentosa para a exposic $\square$ ão ao HIV antes ou após a mesma, ampliação de testagem para o HIV e introdução ARV independentemente da carga viral. Ainda que endossando a importância de tais estratégias, deve-se refletir sobre o risco de relegar para segundo plano, ou mesmo abandonar, outras estratégias exitosas de prevenção, igualmente importantes para o enfrentamento do HIV/AIDS. Além das mudanças conjunturais nas políticas de aids, a interferência de forças políticas conservadoras podem comprometer a capacidade da resposta brasileira ao HIV/AIDS voltadas para o benefício de populações mais vulneráveis, como gays, prostitutas e travestis, exemplo da suspensão da campanhas publicitárias de prevenção do HIV/AIDS dirigidas às prostitutas (173) e HSH (174).

Por fim, ainda que as estratégias descritas possam oferecer oportunidades de incluir no campo da prevenção outras perspectivas para além do modelo heteronormativo e binário

\footnotetext{
${ }^{102}$ Para maiores informações sobre esta técnica: http://www.aids.gov.br/fluido_oral Acessado em $15 / 10 / 2014$

${ }^{103}$ A metodologia deste projeto prevê um modelo de intervenção baseado na educação de pares, processo de ensino e aprendizagem em que grupos sociais atuam como facilitadores de ações e atividades com e para seus pares. No caso do projeto citado, a equipe é geralmente composta por um(a) coordenador(a) e três educadores(as) de pares [citado em 2014 Out. 14]. Disponível em: http://www.aids.gov.br/noticia/2014/coordenadores-estaduais-e-municipais-se-engajam-no-projeto-detestagem-com-ong
} 
de gênero, tem-se uma limitação de estudos de avaliação destas estratégias ${ }^{104}$, que impossibilita afirmar os efeitos práticos destas iniciativas na vida de travestis e transexuais. De qualquer modo, em face da habitual moralidade das ações (ou omissões em agir) humanas que comprometem a saúde de travestis e a vivência plena de suas potencialidades e projetos de vida, o conjunto de estratégias são importantes para evidenciar as situações cotidianas que agregam vulnerabilidades e risco para a infecção do HIV/AIDS, possibilitando seu reconhecimento e a formulação das respectivas respostas por parte do poder público.

\subsection{PLANOS NACIONAL E ESTADUAIS DE ENFRENTAMENTO ÀS DST, HIV, AIDS ENTRE GAYS, HOMENS QUE FAZEM SEXO COM HOMENS (HSH) E TRAVESTIS}

Uma estratégia relevante para o enfrentamento da epidemia foi o "Plano Nacional de Enfrentamento às DST, HIV, Aids entre gays, homens que fazem sexo com homens (HSH) e travestis", divulgado no ano de 2008 pelo Ministério da Saúde em parceria com o Conselho Nacional dos Secretários da Saúde (CONASS) ${ }^{105}$ e com o Conselho Nacional das Secretarias Municipais de Saúde (CONASEMS) ${ }^{106}$. A estratégia expressa um compromisso político das três esferas de governo - Municípios, Estados e União que juntamente com os Conselhos, assumem um conjunto de acordos para a implementação de uma política pública de prevenção e controle do HIV/AIDS, a partir do reconhecimento de vulnerabilidades específicas de gays, HSH e travestis.

Minha relação com esta estratégia tem início em 2008, quando na qualidade de assessora técnica do Departamento DST/AIDS/HV, fui indicada para planejar e executar as chamadas "Oficinas Macro Regionais para o Enfrentamento da Epidemia das DST/HIV/AIDS entre gays, HSH e Travestis", voltadas a estabelecer estratégias

\footnotetext{
${ }^{104}$ Para a identificação de tecnologias comprovadas no Brasil, foi realizado no ano de 2012 pela pesquisadora Nancy $\mathrm{K}$. Russell, $\mathrm{PhD}$, uma revisão sistemática que buscou identificar todas as intervenções de prevenção ao HIV documentadas recentemente (2006-2012) (incluindo ações preventivas) conduzidas com HSH, gays e travestis. O estudo intitulado "Intervenções de prevenção de HIV/Aids em HSH, Gays e Travestis no Brasil (2006-2012): Uma Revisão Sistemática realizado pela pesquisadora" identificou 74 intervenções preventivas em HSH, gays e travestis em todas as 5 regiões do Brasil, usando uma ampla variedade de abordagens e estratégias; entretanto, somente duas foram avaliadas adequadamente, e somente uma pôde demonstrar um efeito positivo.

${ }^{105}$ Maiores Informações: http://www.conass.org.br Acessado em 15/10/2014.

${ }^{106}$ Maiores Informações: http://www.conasems.org.br/ Acessado em 15/10/2014.
} 
locais de operacionalização dos "Planos Estaduais" nas 27 Unidades Federativas do Brasil $^{107}$, a exemplo do que ocorrera no Plano Nacional ${ }^{108}$.

Constituído originalmente por duas agendas afirmativas paralelas, uma relacionada ao grupo de gays e HSH e a outra às travestis ${ }^{109}$, os planos estaduais contavam com objetivos, metas e atividades específicas para cada uma destas agendas. A proposta inicial de execução das metas compreendia o período de 2008 a 2011, mas por indicação de alguns estados e municípios tal prazo foi postergado para o período de 2012/2013.

As oficinas foram executadas em parceira com as Coordenações Estaduais de DST e Aids (CE/DST/AIDS) e contaram com a presença de outros setores governamentais ${ }^{110}$, profissionais de saúde e representantes dos movimentos sociais de aids e movimento LGBT. Como decorrência, conta-se a construção de 27 Planos Estaduais de DST/HIV/AIDS.

Por sua relevância em relação à consolidação de uma política pública voltada para travestis, esta pesquisa se propõe a mapear as atividades voltadas para tal grupo que constam nos planos estaduais nas 27 unidades federativas, com base na análise dos

\footnotetext{
${ }^{107}$ O desenvolvimento destes planos não se deu de maneira uniforme: algumas coordenações estaduais de DST/Aids desenvolveram as oficinas conjuntamente com outros estados de uma mesma região; por sua vez, em alguns estados o desenvolvimento do Plano se deu em diferentes etapas entre os anos de 2008 a 2010.

${ }^{108}$ A elaboração do Plano Nacional contou com uma equipe de 26 assessores técnicos, além do aporte técnico de representantes dos movimentos de aids, incluindo pessoas que vivem com HIV/Aids (PVHA), e representantes do movimento LGBT, além de profissionais de saúde, gestores e pesquisadores das temáticas relacionadas a população LGBT.

109. O Movimento Nacional de Mulheres Transexuais, optou por participar do Plano Integrado de Enfrentamento das DST/HIV/Aids entre mulheres.

${ }^{110}$ Nestas oficinas foram convidados pelos Programas Estaduais de DST e Aids, representantes dos Programas Municipais de DST e Aids, incluindo as capitais; Coordenação de Atenção Básica; Área Técnica de Saúde do Adolescente e do Jovem; Programa de Hepatites Virais; Área Técnica de Saúde Mental; Conselho Estadual de Saúde; COSEMS; CONASS; Secretaria Estadual de Educação; Área de Direitos Humanos; Secretaria Estadual de Justiça; Secretaria Estadual de Segurança Pública; Secretaria Estadual de Promoção/Assistência Social; Secretaria Estadual de Cultura; Secretaria de Administração Penitenciária, pesquisadores e representação do movimento social LGBT.
} 
documentos disponíveis no site do Departamento de DST, HIV, Aids e Hepatites Virais do Ministério da Saúde ${ }^{111}$.

A interpretação das atividades priorizou a identificação daquelas voltadas a prevenção, promoção e assistência ao HIV/AIDS relacionadas às travestis, marcador que foi usado para selecionar tais ações.

Uma primeira leitura dos planos estaduais possibilitou uma aproximação inicial do cenário geral das propostas de ações por Estado, após o que foram estabelecidas cinco categorias, a partir dos princípios norteadores do SUS: 1) Fortalecimento e Participação da Sociedade Civil; 2) Educação em saúde - incluindo a formação de recursos humanos; 3) Integralidade da assistência no cuidado; 4) Comunicação; 5) Ações específicas para travestis. Alguns exemplos de propostas de atividades contidas nos planos foram citados no texto abaixo para ilustrar os entendimentos trabalhados nesta pesquisa, entretanto, neste momento optou-se por não se identificar o estado relativo a cada atividade destacada, por entender que os exemplos citados não se referem somente aquela determinada localidade. Para compreensão mais completa das propostas por Estado, sugere-se a leitura na íntegra de cada um dos Planos Estaduais.

A análise dos Planos Estaduais de Enfrentamento às DST, HIV, Aids entre gays, HSH e travestis, conforme anexo 01, demonstra o quanto apontado fartamente neste trabalho, que as ações de prevenção à aids são direcionadas predominantemente para gays, HSH e travestis, indistintamente, de modo que as ações para a população de gays e HSH preponderam em detrimento do volume bem menor de ações relacionadas às travestis. Destaca-se que esta diretriz está em desacordo com o Plano Nacional, o qual que orientou o desenvolvimento dos planos estaduais, no qual se afirmava a importância de agendas específicas para cada um dos segmentos populacionais.

Importante notar que o menor direcionamento de intervenções de prevenção ao HIV para travestis também foi ressaltado na "Revisão sistemática das intervenções de prevenção de HIV/AIDS no Brasil" (15). Tal estudo identificou 74 artigos, resumos, teses e relatórios que descreviam intervençōes preventivas envolvendo $\mathrm{HSH}$, gays e

\footnotetext{
111 Os planos estão disponíveis no endereço eletrônico: http://bvsms.saude.gov.br/bvs/publicacoes/plano_enfrentamento_epidemia_aids_hsh.pdf. Acessado em $21 / 10 / 2014$
} 
travestis em todo o Brasil; embora mais de dois terços destes estudos tenham indicado que as interveções direcionavam-se especificamente à travestis ou transgêneros, na análise da descrição de tais intervenções contatou-se que, na realidade, mais da metade destas direcionava-se a populações LGBT de forma genérica e apenas 10\% tinham como público específico as travestis ou transgêneros.

O mapeamento dos planos estaduais evidenciou também que em relação as atividades específicas para travestis destacam-se:

$\checkmark$ Produzir conhecimento sobre a "participação" deste público na epidemia de aids, por meio da inclusão da categoria "travesti" nos sistemas de informação e de monitoramento dos Centros de Testagem e Aconselhamento;

$\checkmark$ Divulgação do direito ao "uso do nome social", tendo como pano de fundo o direito ao respeito à identidade de gênero e, consequente, o reconhecimento a autonomia sobre o próprio corpo;

$\checkmark$ Ações relacionadas com os processos de modificação corporal, tais como: avaliação e acompanhamento médico que reduzam os efeitos colateriais do uso de hormônios sexuais que têm efeitos feminilizantes (estrôgenio) ou masculinizantes (androgênio); divulgação de informações para redução de riscos relacionados a alterações de partes específicas do corpo, tais como a forma de suas mamas, nádegas, pernas, lábios, bochechas ${ }^{112}$;

$\checkmark$ A revisão dos horários de atendimento nos serviços de saúde para facilitar o acesso das travestis;

$\checkmark$ Ampliação do acesso a "Testes Rápidos para detecção do HIV"113, de fácil execução e interpretação, que podem ser utilizados fora do ambiente laboratorial.

\footnotetext{
${ }^{112}$ Muitas vezes as condições precárias de higiene no local da administração possibilitam contaminação química, bacteriana ou fungos, assim como complicações relacionadas com a prática de injetar silicone industrial ou óleos de parafina diretamente no tecido celular subcutâneo, podendo ter como consequência úlceras, migração de produtos, abcessos, infeções, dentre outros

${ }^{113}$ Esta tecnologia faz parte da estratégia do Ministério da Saúde que visa ampliar o acesso ao diagnostico do HIV, especialmente em gestantes e populações em contextos de maior vulnerabilidade, tais como as travestis; os testes rápidos, por suas características de fácil execução e interpretação, podem ser utilizados fora do ambiente laboratorial por pessoas capacitadas para essa metodologia. Para maiores informações: www.aids.gov.br Acessado em 10/10/2014
} 
Do ponto de vista da bioética de intervenção, tais propostas remetem a discussão da promoção da autonomia, pois uma vez que modificações corporais feitas através do uso de silicone e hormônios, por exemplo, fazem parte da construção da identidade deste sujeito, quando a saúde pública não é capaz de garantir atendimento universal, equânime e integral negam-se os direitos indispensáveis da busca da felicidade e autodeterminação de um sujeito moral livre.

Neste sentido, Schramm et. al (175) advertem que não existem razões moralmente cogentes para se desconsiderar as decisões relacionadas ao desejo de realizar modificações sobre o próprio corpo, já que a cultura dos direitos fundamentais inclui a liberdade individual, neste caso, as decisões individuais teriam prioridade em relação as demais decisões contrarias, por se tratar de fonte relevante de sofrimento.

O gerenciamento de corpos e comportamentos retoma a lógica do modelo higienista da França do Século XIX, onde os comportamentos de pobres e excluídos eram tidos como "inadequados" e, consequentemente, eram atribuídos aos mesmos "pobres e excluídos" a responsabilidade pelas doenças e epidemias da época (176).

Outro fato que chama a atenção é a exiguidade de propostas dirigidas às travestis que vivem com HIV/AIDS, já que além da necessária observação das necessidades especificas das pessoas que vivem com HIV e aids (PVHA) pelos serviços de saúde, a vivência da sexualidade, essencial na vida de todas as pessoas, costuma passar por transformações importantes após um diagnóstico positivo para o HIV. Em especial para aqueles que não se enquadram nos padrões heteronormativos, o estigma e a culpabilização, discutidos anteriormente, ratificam medos e preconceitos, além disso, o temor de ser rejeitada, de infectar os (as) parceiros (as) pode afetar negativamente a autoestima, bem como acrescentar problemas "de mercado" para as que atuam como profissionais do sexo. Assim o estigma que persiste em acompanhar as travestis, pode ser potencializado via manifestação e reconhecimento público do HIV/AIDS.

Além disso, para aquelas que fazem uso dos antirretrovirais (ARV), o temor das mudanças físicas provocadas pelos medicamentos, como a lipodistrofia, podem desestimular a continuidade do tratamento. Segundo Pelúcio (38), não é incomum que a aids seja tomada entre travestis como um "termo de acusação que serve para 
comprometer aquela/aquele que se deixa contaminar", expresso em sentenças como "aids é coisa de bicha burra".

Além de todos os motivos elencados acima, a proteção do outro, bem como sua própria (relacionada a reinfecção), seriam motivos suficientes para a oferta de estratégias de prevenção continuadas a tal público. De acordo com Ayres:

Não podemos esquecer que a vulnerabilidade que levou os indivíduos a se infectarem não desaparece porque as pessoas se infectaram, embora às vezes se modifique um pouco, os soropositivos não vivem em outro mundo. Seus contextos de interação intersubjetiva permanecem, em geral, muito pouco alterados (91).

A mesma linha de raciocínio pode ser aplicada às travestis profissionais do sexo, desproporcionalmente afetadas pelo HIV/AIDS e para quem as ações propostas, além de escassas e inespecíficas permanecem silenciadas e invisíveis nas políticas públicas. . O duplo estigma da prostituição e da travestilidade é um desafio que intersecciona diferentes vulnerabilidades intersecciona diferentes vulnerabilidades e reforça o não lugar político das travestis-profissionais do sexo.

Importante destacar que a prostituição é compreendida socialmente como imoral e repleta de erros, imprimindo como características as práticas de violências de desordens e desajustes sociais. O relato de uma travesti, descrito por Pelúcio (38) no artigo "Marcadores sociais da diferença nas experiências travestis de enfrentamento à aids" expressa com precisão os sentimentos de medo e isolamento relacionados a esta doença:

Nesse meio você não tem com quem contar. Porque se você fala certas coisas com ela [uma colega de rua, hipotética], ela começa a contar pra rua toda. Por exemplo, se eu sou uma bicha de estrela e entro muito [faz muitos programas], se ela fica sabendo de algum problema meu, ela vai querer queimar meu filme. Tanto que aquela bicha lá foi queimada na internet, né? Aquela que se jogou... Camila! Se jogou, né? De tanta pressão (Entrevista concedida à pesquisadora em 14/11/2005, na residência de Márcia).

Pasini (177) em sua dissertação sobre prostituição de mulheres na rua Augusta (São Paulo) observa que os espaços de prostituição são delimitados físico e simbolicamente e , são nestes locais "que elas estabelecem trocas e constituem relações com pessoas do 
mundo da prostituição". Segundo Benedeti (131) é na rua da prostituição que se aprende e se faz uma travesti profissional do sexo. Neste sentido:

As interações na prostituição e no mundo da noite conformam espaços/temporalidades e redes por onde elas transitam constituindo uma resposta positiva ao ostracismo e isolamento social a que são submetidas. Esses espaços são permeados por relações sociais que extrapolam o mercado do sexo, permitindo apreender os códigos que conformam seus destinos e suas subjetividades (178).

No que concerne ao uso de drogas, as propostas utilizam o termo "redução de danos" como uma espécie de "guarda-chuva" temático, ou seja, supostamente capaz de abrigar diferentes abordagens. A maior parte das propostas não permite visualizar se incluem a necessária discussão sobre o efeito do uso de substâncias sobre as práticas sexuais, já que muitas drogas como álcool, maconha, cocaína e ecstasy alteram os sentidos e a percepção de risco dos usuários podendo dificultar a negociação do uso do preservativo nas relações sexuais. Em relação às drogas injetáveis, também não é evidente como serão realizadas as ações de prevenção relacionadas ao compartilhamento de agulhas, seringas e recipientes para a diluição da droga (cocaína), como práticas de altíssimo risco para a infecção do HIV. Tampouco se esclarece a necessária recomendação para utilização de equipamentos individualizados para uso de drogas.

Quanto ao fortalecimento e participação da sociedade civil ${ }^{114}$, a grande maioria das propostas correspondem à organização de eventos, seminários e encontros pontuais, assim como o incentivo para que representantes do movimento LGBT participem de fóruns e comitês de saúde, geralmente incluídos nas políticas de enfrentamento ao HIV/AIDS e/ou à diversidade sexual. Vale destacar que, em grande parte, o incentivo à participação específica de travestis em espaços de proposição e monitoramento das políticas públicas na maior parte dos planos ficou incluída na comunidade LGBT genericamente. Da mesma forma é citada, com muita frequência, a necessidade do fortalecimento de lideranças, conforme exemplo abaixo:

\footnotetext{
${ }^{114}$ Tomando o fortalecimento e a participação da sociedade civil como o direito e o dever da sociedade em participar da construção e do monitoramento de políticas públicas, entende-se como dever do estado garantir as condições para tal participação, assegurando a gestão comunitária do SUS. BRASIL. Lei n. ${ }^{\circ}$ 8.142 de 28 de dezembro de 1990. Dispõe sobre a participação da comunidade na gestão do Sistema Único de Saúde - SUS e sobre as transferências intergovernamentais de recursos financeiros na área da saúde e dá outras providências. Brasília: Ministério da Saúde, 1990.
} 
Criação, implementação, fortalecimento e mobilização do movimento das travestis, mediante a realização de evento/oficina com a presença de alguma travesti que possa contribuir para a organização do movimento e de seminário, visando fortalecer as lideranças existentes e aproximá-las dos serviços.

As estratégias de incentivo a participação política e o engajamento comunitário, embora para alguns pareçam ultrapassadas, segundo Paiva (179) têm se provado eficazes para garantir melhor acesso ao cuidado de saúde e ao tratamento de HIV para populações mais afetadas, estimulando assim a coesão social, participação coletiva e o acesso aos serviços.

Os planos também propõem ampliar o conhecimento a respeito das OSC locais, mapeando aquelas com atuação junto ao público de gays, HSH e travestis; além de prever o apoio as mesmas por meio de editais de projetos voltados a realização de trabalhos de prevenção às DST/HIV/AIDS. Conforme exemplos abaixo:

Garantir a inserção anual, nos editais de seleção de projetos para OSC, o eixo temático que vise o desenvolvimento de ações de prevenção e promoção voltadas à população de gays, HSH e travestis.

Mapear as organizações não governamentais que trabalham com Gays, HSH e/ou travestis.

Em relação à educação em saúde ${ }^{115}$, predominam nos planos propostas de capacitação de profissionais de saúde para o enfrentamento da homofobia e, em menor quantidade, da transfobia, a exemplo da atividade descrita abaixo:

Articular com gestores municipais a realização de cursos de formação de profissionais de saúde para o enfrentamento da homofobia e atendimento humanizado a gays, outros $\mathrm{HSH}$ e travestis.

Um grande número de propostas expressa também a necessidade de inclusão, nas capacitações para profissionais de saúde, daquilo que os estados indistintamente

\footnotetext{
${ }^{115} \mathrm{~A}$ educação em saúde é compreendida como um processo político pedagógico, que carece do desenvolvimento de um pensar crítico e reflexivo que possibilite desvelar a realidade e propor ações transformadoras, enquanto sujeito histórico e social capaz de propor e opinar nas decisões de saúde para a coletividade (198).
} 
designam por "temáticas relacionadas à diversidade sexual" ou "temáticas das populações de gays, outros HSH e travestis", conforme exemplo abaixo:

Realizar encontro entre gestores municipais e dos Centros Regionais de Saúde para sensibilização referente às temáticas das populações de gays, outros HSH e travestis.

Parece haver também um grande interesse em realizar capacitações para profissionais de saúde em temas relacionados com a prevenção das DST, HIV e aids para gays, HSH e travestis, ainda que se trate de atividade essencial que deveria estar incorporada como rotina num serviço de qualidade. Além disso, de um modo geral, os planos não definem o que será tratado neste universo da prevenção para tais populações:

Realizar oficinas de capacitação em estratégias de prevenção para o enfrentamento da epidemia entre gays, outros $\mathrm{HSH}$ e travestis para as equipes dos 26 municípios com incentivo, em parceria com a sociedade civil.

Muitos planos citam a importância da capacitação dos profissionais para a humanização do atendimento e acolhimento voltados à população de gays, HSH e travestis, como mostra o exemplo:

Articular a realização de cursos de formação para profissionais de saúde visando atendimento humanizado para este segmento e identificação das vulnerabilidades da população de gays, HSH e travestis.

Capacitar e sensibilizar profissionais de saúde dos serviços de diagnóstico e aconselhamento em DST/HIV/AIDS sobre especificidades do acolhimento de gays, outros HSH e travestis, como: diversidade, orientação sexual e identidade de gênero.

Para Mello, L. (153) esse tipo de proposta parece contraditória com um sistema de saúde universal e equitativo: "Seguramente, em um cenário ideal, todas as pessoas deveriam ser atendidas de forma humanizada e respeitosa em qualquer unidade de saúde, a partir de estrutura de acolhimento construída nos termos propostos pelo SUS”. Seguem os autores afirmando que enquanto isto não ocorre, é necessário que se reconheçam os limites das política publicas universais e do princípio da equidade, ao se considerar as especificidades das demandas de segmentos sociais discriminados.

Vale notar que o tema "vulnerabilidade" aparece nos Planos com grande elasticidade conceitual, utilizando-se em qualquer sentido e qualquer população, tanto para a população de gays e HSH, quanto de travestis, daí que não se consegue distinguir quais os fatores que vulnerabilizam especificamente cada grupo. Neste sentido, não fica claro 
o que cada proposta de atividade compreende como vulnerabilidade e qual o nível de relevância será dado àquelas questões mais diretamente relacionadas ao universo das travestis. Como exemplo:

Realizar ofícina para sensibilização e capacitação de profissionais e estudantes dos meios de comunicação em temas referentes à vulnerabilidade de gays, outros HSH e travestis às DST, hepatites e HIV/AIDS.

As propostas no campo da educação em saúde, de um modo geral, são estratégias pontuais e se destinam majoritariamente aos profissionais de saúde. Neste sentido, as ações voltadas para a redução do estigma, principal problema relatado pelas travestis, aparecem em menor proporção, daí a importância de reiterar que a melhoria da qualidade da atenção à saúde desta população é uma ação relevante, que em alguns contextos irá exigir um esforço contundente na articulação política e institucional. É possível identificar nesta categoria que o distanciamento em relação às travestis se produz nas próprias universidades, quando silenciam ou patologizam sobre corpos trans; e mesmo que diferentes tratados e documentos públicos tenham observado a necessidade de se considerar as relações e as identidades de gênero como determinantes de saúde, os Planos avaliados demonstram que estes conceitos ainda não são absorvidos pela maioria das pessoas e programas, uma vez que referente à formação de profissionais de saúde os planos referem-se somente a "diversidade sexual", como uma questão suficientemente abrangente para dar conta das demandas da população de travestis. Desta maneira, desconsidera-se o artigo 10 da DUBDH, que engloba os valores da igualdade, justiça e equidade, ao garantir que "a igualdade fundamental de todos os seres humanos em dignidade e em direitos deve ser respeitada para que sejam tratados de forma justa e equitativa”.

Em relação à Integralidade da assistência no cuidado ${ }^{116}$, a rigor, as atividades propostas nos planos abordam a realização de articulações do setor HIV/AIDS com diferentes áreas do SUS, tais como as áreas técnicas da pessoa idosa, saúde do homem,

\footnotetext{
${ }^{116}$ Integralidade da assistência no cuidado: é aqui entendida a partir dos princípios do SUS como um conjunto articulado de ações e serviços de saúde, preventivos e curativos, individuais e coletivos, no qual as ações de promoção, prevenção e de recuperação devem formar um todo indivisível, assim como precisam ser combinadas e voltadas, ao mesmo tempo, para a prevenção e a cura buscando contemplar as necessidades em todos os níveis de complexidade do sistema.
} 
educação, sistema prisional, programas de tuberculose, etc. O setor empresarial também é citado como parceiro no enfrentamento à homofobia/transfobia, tais como:

Articular com o setor empresarial o desenvolvimento de campanha de combate a homofobia/transfobia nas empresas privadas.

Muitos planos discorrem de forma inespecífica sobre a importância de pautar nos conselhos estaduais de saúde as temáticas relacionadas com a população LGBT, como exemplo:

Pautar, junto aos colegiados gestores (Conselho Estadual de Saúde, Tripartite, COSEMS) as temáticas que envolvem a população LGBT.

Identificar e criar parcerias dentro das redes estadual e municipais para execução de ações específicas para travestis.

Os conselhos empresariais aparecem como locais de intersetorialidade, entretanto, grande parte das ações propostas também mostram-se inespecíficas e não possibilitam avaliar o que foi planejado para a população de travestis, como exemplo:

Envolver o Conselho Empresarial de DST/Aids/Hepatites Virais na elaboração de ações de prevenção das DST/AIDS para gays, $\mathrm{HSH}$ e travestis.

Em relação à comunicação em saúde ${ }^{117}$, a produção de materiais informativos e/ou desenvolvimento de campanhas temáticas foram as atividades mais citadas nos planos, como estratégia para o enfrentamento da homofobia e da transfobia, assim como da prevenção das DST/HIV/AIDS. Como por exemplo:

Produção, veiculação e qualificação de campanhas municipais e/ou regionais dirigidas aos gestores, gerentes e profissionais de saúde, inserindo mensagens em contas de água, luz, telefone, etc.

Realizar, no ano de 2011, uma campanha de comunicação com a temática da diversidade sexual.

A diversidade sexual é um dos marcadores que compõe o universo das travestis, entretanto, vale mencionar que nestes casos a estigmatização é composta por um grupo de fatores que não podem se restringir à "diversidade sexual", uma vez que o preconceito associado, por exemplo, ao binarismo de gênero e ao trabalho sexual

\footnotetext{
117 Comunicação e Saúde é um termo que indica uma forma específica de ver, entender, atuar e estabelecer vínculos entre estes campos sociais (200).
} 
constituem-se em fatores determinantes para os contextos de vulnerabilidades relacionados ao HIV/AIDS para este grupo.

Nota-se também que a redução das vulnerabilidades individuais, sociais e programáticas são propostas como uma espécie de "tema chave" para as ações de prevenção voltadas para gays, HSH e travestis, como por exemplo:

Realizar ações de comunicação e informação específicas que contribuam para a redução de contextos de vulnerabilidade social, institucional e individual associados às DST/HIV.

Neste caso, embora haja vulnerabilidades compartilhadas entre os três segmentos, a falta de foco nas vulnerabilidades específicas de travestis é também uma característica destas propostas, pois diferentemente dos outros grupos sociais, questões como menor nível de escolaridade, local de moradia, violência intrafamiliar, menor acesso ao trabalho formal, são apenas alguns exemplos das situações que afetam de maneira particular este segmento. Como exemplo:

Produzir material impresso (banners, cartazes e folhetos) que contribuam para a redução da vulnerabilidade às DST, hepatites e HIV/AIDS associadas à homofobia.

Realização de formações e produção de material de referência para a organização dos serviços de saúde e a formação de seus profissionais para acolher e não discriminar gays, HSH e travestis.

Outra característica relacionada às campanhas publicitárias é a noção de que imagens que "impactem" o público em relação ao HIV/AIDS trariam particular benefício a população de gays, HSH e travestis. Como exemplo: "Realização de campanhas com imagem que impactem no público de gays, HSH e travestis".

Vale observar que durante a década de 80 e início da década de 90, muitas campanhas e materiais informativos, enredados em preconceitos e desinformação, serviram para reforçar temores ao rotular os portadores de HIV como pessoas fadadas a morte. Com o avanço do conhecimento sobre a doença o discurso mudou e as campanhas oficiais passaram a focar na prevenção e no reconhecimento do preconceito e do estigma como um dos piores problemas relacionados à aids. Neste sentido, os Planos não descrevem quais seriam as tais "imagens que impactariam" o público, mesmo assim vale refletir sobre o histórico do impacto das campanhas realizadas no início da epidemia, quando se instalou grande pânico ao redor do mundo, ao atribuir-se nas campanhas sentidos de 
terror à síndrome e culpabilização individual. Pergunta-se: em que medida campanhas que "impactam determinados grupos" podem resultar de fato em proteção e dignidade desta população? De outro lado, em que medida as campanhas podem levar a um acirramento do estigma e do preconceito contra grupos já historicamente marginalizados?

A exceção do exemplo abaixo, a utilização de recursos midiáticos relacionados à internet (redes sociais) para a mobilização de gays e HSH não é referida pelos estados:

Criar estratégias em multimídia, cursos à distancia (internet, rádio comunitária, comunidade virtual, blogs, Orkut) para estabelecer redes de disseminação de informações e orientações e divulgação de evento.

Neste caso, vale ressaltar a importância destes meios de comunicação para tal grupo social, considerando inclusive as travestis que utilizam as redes de comunicação e chats para encontros com amigas e parceiros afetivo/amorosos. De acordo com a avaliação das apresentações feitas na última "Conferência Internacional de Aids ocorridas em Melbourne AUS, 2014", as abordagens comunitárias inovadoras de enfrentamento ao estigma e à discriminação, atualmente têm como característica o uso de mídias sociais, internet e de telefones celulares, conforme Paiva (179).

Muitas estratégias citam a confecção de materiais educativos para profissionais de saúde com a proposta de estimular o "atendimento humanizado". Nestes casos, é curioso pensar sobre a capacidade destes materiais de "humanizar o atendimento", uma vez que, conforme descrito pelos diversos autores aqui tratados, as travestis são consideradas por grande parte da sociedade como um "estranho moral", alguém "desprovido de humanidade".

\subsection{CONSIDERAÇÕES A PARTIR DA DECLARAÇÃO UNIVERSAL DE BIOÉTICA E DIREITOS HUMANOS (DUBDH)}

Se a prevalência de aids entre travestis parece superar substancialmente outras categorias populacionais, como gays, usuários de drogas e profissionais do sexo, poderse-ia supor, como dever do estado frente às mazelas e vulnerabilidades enfrentadas pelas mesmas, a formulação de estratégias condizentes com as características desta população. Todavia, de modo geral, as especificidades das travestis não são consideradas na elaboração, planejamento e consecução das política públicas em saúde. 
Neste sentido, parece-nos razoável inferir que reside aí uma tensão entre os princípios de equidade, justiça social, o respeito à dignidade da pessoa humana, elencados na DUBDH, em face da moralidade das ações humanas que afetam significativamente esta população.

Conforme o art. 14 da DUBDH, a promoção da saúde e do desenvolvimento social para a sua população é objetivo central dos governos e deve ser partilhado por todos os setores da sociedade. Assim, as propostas de ações sanitárias e educacionais voltadas para a população de travestis tanto podem indicar a preocupação do estado em proteger a integridade, dignidade e autodeterminação destas pessoas, quanto podem, ao invés disso, revelar o desejo em manter quem vive em acordo com o modelo heteronormativo e binário de gênero (aqueles considerados usualmente "pessoas-normais") livres da situação de risco e vulnerabilidades associadas a determinados grupos e praticas sexuais. No caso das atividades propostas nos planos estaduais, analisadas acima, é difícil identificar em que medida uma ou outra preocupação prevalece, uma vez que boa parte das atividades apresentadas, sobretudo em relação às travestis, não permite a visualização do que exatamente está sendo proposto. Como exemplo:

Realizar ações de sensibilização e capacitação para profissionais da área de segurança publica acerca dos temas LGBT.

Identificar e criar parcerias dentro das redes estadual e municipais para execução de ações específicas para travestis.

O esforço de superação dos limites relacionados ao antigo modelo preventivo, até então focado num esquema cognitivo-comportamental, para uma atenção mais vigorosa nos fatores estruturais e sociais, focando as pessoas não tanto em suas individualidades mas como sujeitos sociais, está assinalado nos Planos, quando apresentam respostas para intervenções estruturais, fortalecimento comunitário e construção de cidadania, tais como: propostas de alternativas nos horários de atendimento nos serviços de saúde para travestis, fortalecimento das OSC e sensibilização de profissionais de saúde para as temáticas LGBT, dentre outros.

Entretanto, ainda que este modelo possa ser considerado um avanço do ponto de vista da resposta à epidemia de aids, é necessário estar atento para que a "racionalidade técnica", característica das estratégias e políticas públicas não se traduzam em desacertos nas estratégias de prevenção e proteção dos sujeitos especialmente 
vulneráveis, sobretudo quando valores e normas supostamente universais (a exemplo da heteronormatividade) são apontadas como parâmetros a serem seguidos por populações que não encontram reciprocidade nas mesmas, ou seja, tais normas não são capazes de acolhê-las e contemplá-las em suas demandas. No caso da população estudada, vale notar que valores compartilhados como "normais" e "adequados" por gestores, profissionais de saúde e comunidade em geral nem sempre refletem o cotidiano e os desejos da população de travestis.

Desta maneira, propostas como o desenvolvimento de formação para profissionais de saúde a respeito, por exemplo, da diversidade sexual de travestis, podem tanto abarcar a diversidade de maneira positiva quanto apresentá-la como algo "anormal e patológico", a partir de um referencial heteronormativo.

Neste sentido, Homi Bhabha (180) alerta que a categoria designada como "diversidade" corresponderia a uma lógica liberal e não libertária, focada na segmentação cultural, a diversidade seria uma espécie lócus em que se circunscrevem grupos e homogeniza-se sujeitos. Para Pelúcio (179), no caso específico da prevenção da aids, a opção pela "diversidade" como um referencial apenas descritivo e não teórico metodológico "tende a apagar os marcadores efetivamente significativos, úteis para a compreensão das continuidades e descontinuidades nas representações sobre corpo, emoção, pessoa, doença e saúde".

As decisões em relação ao modelo de saúde são baseadas em alternativas tidas como "eficientes" e "comprovadamente exitosas", entretanto, basear-se na calculabilidade destas escolhas pode levar a anulação de subjetividades e dos determinantes socioculturais que afetam justamente aqueles que deveriam ser beneficiados, consequentemente, interferindo negativamente no resultado das ações, conforme Pelúcio (181).

Uma grande parcela das estratégias tem como mote o respeito aos direitos humanos e as liberdades fundamentais e apresentam-se, a princípio, em consonância com o art. 10 da DUBDH - Igualdade, Justiça e Equidade: “A igualdade fundamental entre todos os seres humanos em termos de dignidade e de direitos deve ser respeitada de modo que todos sejam tratados de forma justa e equitativa". Por seu turno, o art. 11 - NãoDiscriminação e Não-Estigmatização, que informa: "Nenhum individuo ou grupo deve 
ser discriminado ou estigmatizado por qualquer razão, o que constitui violação à dignidade humana, aos direitos humanos e liberdades fundamentais".

A exemplo do enfrentamento a homo/transfobia, as campanhas configuram-se como estratégias importantes para o enfrentamento da epidemia de aids, contudo, não devem representar, na concretude, a totalidade das ações de prevenção, já que a produção de cartazes, banners e outros materiais informativos são insuficientes para promover, por si só, mudanças a favor da prevenção, mas podem criar ambientes favoráveis à promoção da saúde, desde que também exista a disseminação de uma estratégia complexa de intervenções de enfoque biomédico, comportamental e estrutural, com base no arcabouço fornecido pela bioética.

Ao estimularem a implicação do movimento social nos espaços de diálogo e deliberação política da saúde, além dos espaços de articulação e decisão sobre prevenção e direitos de LGBT, os planos buscam elevar o grau de exercício da cidadania através de um maior envolvimento da sociedade civil no que se refere a seus interesses, deslocando a responsabilização da doença do plano individual para a forma como os indivíduos se relacionam entre si e com seu entorno.

Contudo, mesmo considerando os avanços destas estratégias, os planos, majoritariamente, citam a importância da representação das comunidades LGBT de forma generalista, sem identificar a complexidade inerentes a cada um destes grupos (ou "letras"). Desta maneira, diminui-se a oportunidade de alcançar a igualdade, justiça social e equidade inscritas na DUBDH, pois ao se pressupor que o grau de cidadania conquistada entre os diversos grupos - lésbicas, gays, bissexuais, travestis e transexuais - sejam correspondentes, perde-se a chance de garantir que diferentes interesses e valores existentes na sociedade possam reverberar na arena decisória das políticas públicas.

Outro ponto observado é que o respeito pelas vulnerabilidades humanas e pela integridade individual, na linha do quanto estabelecido no art. $8^{\circ}$ da DUBDH, ainda é um desafio para a promoção de acesso equitativo, na medida em que prevalece a contradição do sistema de saúde, cujos princípios incluem a integralidade e a equidade, mas que ainda demanda capacitação de profissionais para garantir "acolhimento" e "atendimento humanizado", além de se estabelecerem "profissionais de referência" para 
tais populações, quando todo o sistema, que é universal, deveria estar preparado para acolher a diversidade e a complexidade da existência humana.

Vale citar também que outros contextos passíveis de agravar as vulnerabilidades para o HIV, tais como sofrimento mental, violência sexual, prostituição, uso de drogas, resistência com o uso do nome social, abandono escolar (que atinge particularmente as travestis), dificuldade para acessar serviços que possibilitem as mudanças corporais, foram pouco considerados nas propostas e planos.

Tais formulações parecem estar em desacordo com o princípio da dignidade humana e direitos humanos, no qual a dignidade humana, os direitos humanos e as liberdades fundamentais devem ser respeitados em sua totalidade, conforme art. 8 da DUBDH Respeito pela Vulnerabilidade Humana e pela Integridade Individual: "A vulnerabilidade humana deve ser levada em consideração na aplicação e no avanço do conhecimento científico, das práticas médicas e de tecnologias associadas. Indivíduos e grupos de vulnerabilidades específicas devem ser protegidos e a integridade individual de cada um deve ser respeitada.

Ainda que os Planos possam ser compreendidos como compromissos assumidos pelo governo federal e pelos governos locais em prol de grupos sociais historicamente excluídos, conforme art. 14 da DUBDH, as travestis seguem historicamente negligenciadas e invisibilizadas, com poucas oportunidades de exprimir seus interesses em espaços de proposição política. Ocorre que só os interesses exprimíveis na sociedade civil são objetos de ações políticas, portanto, os interesses das travestis precisam ser traduzidos em demandas por direitos, garantindo-se espaços para que possam ser expressos livremente, deve ser incentivada uma maior participação deste grupo social nos espaços de proposição política, caso contrário, suas demandas não serão capturadas e/ou legitimadas e, portanto, nunca incluídas. 


\section{CONSIDERAÇÕES FINAIS}

O volume de infecções pelo HIV e de casos de aids entre as travestis implica no reconhecimento da gravidade da epidemia entre esta população, e, consequentemente, demanda uma revisão das estratégias de prevenção com vistas a atenuar os impactos deste fenômeno, até que se encontre sua cura definitiva. Neste sentido, buscou-se dialogar com o campo da prevenção aspectos da bioética de intervenção que envolvem esta problemática, afim de tecer considerac $\square$ ões sobre possíveis abordagens para o problema que estejam mais alinhadas com os preceitos da Declaração de Bioética e Direitos Humanos (DUBDH).

Por meio dos princípios elencados na DUBDH, entende-se que os grupos particularmente vulneráveis devem ser protegidos e sua integridade individual respeitada, o que reforça o princípio da dignidade humana na qual o valor incondicional do homem é reificado pela exigência de sua inviolabilidade, assegurando o direito à vida e às liberdades fundamentais, incluindo aquelas relacionadas a autodeterminação, como indispensáveis na busca da felicidade e do bem estar.

Este contexto faz emergir um problema já antigo, relacionado com o dever do Estado de promover a saúde e o imperativo de que as pessoas vivendo com HIV e/ou em contextos de vulnerabilidades não sejam expostas a modelos morais e estigmatizantes que levem a sobreposição de vulnerabilidades e sofrimentos evitáveis decorrentes da associação entre seu grupo de pertença e a própria aids.

As travestis trazem em si as marcas do feminino e do masculino, significando o não pertencimento ao chamado "gêneros inteligíveis", o fato das travestis não serem apropriadamente generificadas, nem viverem dentro do imperativo heterossexual, faz com que sejam apreendidas pelos discursos hegemônicos como seres abjetos, e como tal lhes são reservadas as zonas invisíveis e inabitáveis. A recusa social dessas expressões de gênero colocam as travestis em situações de desvantagem e restrições sociais incomparáveis a outros segmentos populacionais considerados, de uma maneira geral, como similares, caso dos gays e dos HSH. Para as travestis restam a violência transfóbica, o estigma e a discriminação como determinantes para os índices mais elevados de HIV/AIDS.

Neste contexto, torna-se ainda mais relevante a atenção que as estratégias de prevenção à aids devem reservar para a interseccionalidade dos marcadores sociais. Tais estratégias, em sua maioria, se limitam a vincular os aspectos relacionados com as 
orientações sexuais, portanto é imprescindível que avance em direção às expressões de gênero, contextos de vulnerabilidades e práticas sexuais, de modo a respeitar a pluralidade moral das diferentes formas e possibilidade de existência deste grupo social.

O presente trabalho propôs-se, com base no arcabouço fornecido pela bioética de intervenção e a luz da DUBDH, contribuir para que as discussões bioéticas se incorporem ao próprio funcionamento do sistema de saúde, no que tange a responsabilidade do Estado frente aos conflitos relacionados à saúde, exclusão e equidade considerando as questões relacionadas ao processo saúde/doença das travestis. Propôs-se ainda problematizar as práticas preventivas para o HIV/AIDS voltadas a este público apresentando questionamentos a respeito dos processos "normatizadores" que condicionam desigualdades entre os grupos sociais, tais como aqueles relacionados com a menor visibilidade das travestis na esfera das políticas de prevenção.

As estratégias de prevenção, descritas no decorrer deste trabalho, configuram-se como tentativas de enfrentamento das iniquidades e desigualdades em saúde, afinadas com os princípios do SUS. Ainda assim há problemas que precisam ser superados para que as demandas em saúde das travestis sejam absorvidas e respondidas pelos serviços públicos, um desafio posto para o enfrentamento da epidemia de aids, problemática discorrida neste trabalho sob a luz da bioética.

Para a qualificação de respostas à epidemia de aids entre travestis é necessário que o silenciamento sobre este tema seja rompido não só no papel mas na efetividade da ação, para tanto "novas" e "velhas" tecnologias de prevenção, novos e velhos olhares devem se conjugar no entendimento dos contextos intersubjetivos geradores de vulnerabilidades e dos direitos humanos deste público, afim de reposicionar as travestis no cenário da epidemia de aids, superando o lugar de "vetor", de quem transmite a aids, para o lugar de sujeito de direitos e dignidade. 


\section{REFERÊNCIAS}

1) Fulgêncio CA, Nascimento WF. Bioética de Intervenção e Justiça: olhares desde o Sul. Revista Brasileira de Bioética.; 2014;8(1-4):46-55. p. 46-55.

2) Goffman E. Estigma: notas sobre a manipulação da identidade deteriorada. 4a ed. Rio de Janeiro (LTC); 1988.

3) Mello L, Perilo M, Braz CA; Pedrosa C. Políticas de saúde para lésbicas, gays, bissexuais, travestis e transexuais no Brasil: em busca de universalidade, integralidade e equidade. Sexualidad, Salud y Sociedad. Revista Latinoamericana; 2011. p. 7-28.

4) Minayo CS. O desafio do conhecimento: pesquisa qualitativa em saúde. $11^{a}$ ed. São Paulo (Hucitec); 2008.

5) Minayo CS. Hermenêutica-dialética como caminho do pensamento social; 2002. p. 83-107. In: Minayo CS \& Deslandes SF (orgs.). Caminhos do pensamento: epistemologia e método. Editora Fiocruz. Rio de Janeiro; 1992.

6) Minayo CS. Op. cit. 2002 . p. 17.

7) Stein E. Dialética e Hermenêutica: uma controvérsia sobre método filosofia. In Jurgen H. Dialética e Hermenêutica. São Paulo: L\&P Editora; 1987.

8) Nascimento WF. Às Margens: Notas Escritas entre a Filosofia e a Sexualidade. Revista Ártemis. 2012;13:21-34:24.

9) Rios RR. O conceito de homofobia na perspectiva dos direitos humanos e no contexto dos estudos sobre preconceito e discriminação. In Pocahy, F. Org. Rompendo o silêncio: homofobia e heterossexismo na sociedade contemporânea. Políticas, teoria e atuação. Porto Alegre (Nuances); 2007.

10) Leone G. Salud, VHI-sida y sexualidad trans: atención de la salud de personas travestis y transexuales. Estudio de seroprevalencia de VIH en personas trans. La primera consulta con una trans. ONUSIDA; 2008.

11) Butler J. Cuerpos que importan: sobre los limites materiales y discursivos del sexo. Buenos Aires: Paidós; 2002.

12) Scott JW. A invisibilidade da Experiência. In: Projeto Historia. São Paulo; 1998.

13) Beauvoir, S. O segundo sexo. Rio de Janeiro. Nova Fronteira; 2000. v. 1 [Fatos e mitos].

14) Bento B. A reinvenção do corpo: sexualidade e gênero na experiência transexual: Editora Garamond; 2006. p. 70.

15) Goode W. Why Men Resist. In Thorne B., Yalom M. Ed. Rethinking the Family: Some Feminist Questions. New York: Longman;1982. 
16) Snodgrass J. For Men against Sexism: A Book of Readings. Albion, CA: Times Change Press; 1977.

17) Tolson A. The Limits of Masculinity. London: Tavistock; 1977.

18) Scott JW. Gênero: uma categoria útil de análise histórica. Educação e Realidade; 1995. p. 71-99.

19) Butler J. Corpos que pesam: Sobre os limites discursivos do "sexo" In: Louro GL. O corpo Educado-pedagogias da sexualidade. Belo Horizonte; 2003.

20) Butler J. Corpos que pesam: sobre os limites discursivos do "sexo". In. O corpo educado: pedagogias da sexualidade. Belo Horizonte: Autêntica; 1999. p. 111.

21) Louro GL. O corpo educado: pedagogias da sexualidade. Belo Horizonte: Autêntica; 2000

22) Louro GL. Op. cit. 2000. p. 04.

23) Oliveira L. Gestos que Pesam-performance de gênero e práticas homossexuais em contexto de camadas populares. (Dissertação). Rio de Janeiro: Saúde Coletiva; Instituto de Medicina Social; 2006. p. 34.

24) Butler J. Problemas de gênero: feminismo e subversão da identidade. Rio de Janeiro: Civilização Brasileira; 2003.

25) Butler J. Le pouvoir des mots. Politique du performatif; 1997. Paris: Éditions Amsterdam; 2004.

26) Butler J. Op. cit. 2003. p. 38-39.

27) Leite JJ. Nossos corpos também mudam: sexo, gênero e a invenção das categorias "travesti" e "transexual" no discurso científico. São Paulo. (Doutorado) Ciências Sociais. Pontifícia Universidade Católica de São Paulo; 2008.

28) Carvalho MFL. Que mulher é essa? Identidade, política e saúde no movimento de travestis e transexuais. (Dissertação). Universidade do Estado do Rio de Janeiro, Instituto de Medicina Social; 2011.

29) Costa RSM. Sociabilidade homoerótica masculina no Rio de Janeiro na década de 1960: relatos do jornal O Snob. (Dissertação). Centro de Pesquisa e Documentação de História Contemporânea do Brasil, Fundação Getúlio Vargas, Rio de Janeiro; 2010.

30) Green JN, Fino C, Leite CA. Além do carnaval: a homossexualidade masculina no Brasil do século XX. Unesp;1999.

31) Fry P. Para inglês ver: Identidade e política na cultura brasileira. Rio de Janeiro, Zahar; 1982.

32) Carvalho MFL Op.cit. 2011. p.23. 
33) Carvalho MFL Op.cit. 2011Op.cit. 28 p. 24.

34) Carrara S, Simões J. Sexualidade, cultura e política: a trajetória da identidade homossexual masculina na antropologia brasileira. Cad. Pagú; 2007.

35) Câmara C. Cidadania e orientação sexual: a trajetória do grupo Triângulo Rosa. Rio de Janeiro: Academia Avançada; 2002. p. 190.

36) Facchini R., França I. Convenções de gênero, sexualidade e violência: pesquisa com participantes de eventos do Orgulho LGBT de São Paulo. Latitude. 2013;7 (Suppl 1): 11-30.

37) Peres W, Toledo L. Travestis, transexuais e trans gêneros: novas imagens e expressões da subjetividade in Psicologia e diversidade sexual. Conselho Regional de Psicologia. Cadernos Temáticos. São Paulo; 2011. p. 86.

38) Pelúcio L. Marcadores Sociais da Diferença nas Experiências Travestis de Enfrentamento à aids. Saúde e Sociedade; 2011. p. 06.

39) Teixeira F. Vidas que desafiam corpos e sonhos: uma etnografia do construir-se outro no gênero e na sexualidade. [Doutorado].Campinas: Universidade Estadual de Campinas, Instituto de Filosofia e Ciências Humanas; 2009.

40) Leite Jr. Nossos corpos também mudam: sexo, gênero e a invenção das categorias "travesti" e "transexual" no discurso científico. [Doutorado]. São Paulo. Pontifícia Universidade Católica de São Paulo, Ciências Sociais; 2008.

41) Barbosa BC. Normas e diferenças: uma etnografia dos usos das categorias travesti e transexual. [Dissertação]. São Paulo. Universidade de São Paulo, Faculdade de Filosofia, Letras e Ciências Humanas; 2010.

42) Leite JJ. Travestis brasileiras e exotismo sexual. Ciências Sociais Unisinos; 2014. p. 44-7.

43) Leite JJ. Op.cit. 2014 p. 50.

44) Martins F, Romão L; Lindner L. (orgs). Manual de comunicação LGBT. Associação Brasileira de Lésbicas, Gays, Bissexuais, Travestis e Transexuais; 2009.

45) Teixeira F. Op.cit. 2009.p.16.

46) Oliveira L. Op.cit. 2006.p.24.

47) Teixeira F. Op.cit. 2009.p.14.

48) Carrijo GG. (Re) apresentações do outro: travestilidades e estética fotográfica. [Tese]. Campinas (SP). Universidade Estadual de Campinas. Instituto de Artes; 2012.

49) Butler J. Vida Precária: El poder Del duelo y la violência. Buenos Aires. Paidós; 2006.p.23. 
50) Butler J. Op.cit. 2006. p. 88.

51) Butler J. Inversões sexuais. In: Passos, ICP. Poder, normalização e violência: incursões foucaultianas para a atualidade. Belo Horizonte. Autêntica Editora; 2008. p. 97.

52) Louis GT. Dictionnaire de l'homophobie. Paris: Presses Universitaires de France; 2003.

53) da Silva AS; Barbosa R. Diversidade sexual, gênero e exclusão social na produção da consciência política de travestis. Athenea digital. 2005;8: 27-49.

54) Spagnol AS. O desejo marginal. São Paulo: Arte e Ciência; 2001. p. 106.

55) Oliveira PP. A Construção social da masculinidade. Belo Horizonte: Editora UFMG/Rio de Janeiro: Instituto Universitário de Pesquisas do Rio de Janeiro; 2004.

56) Oliveira PP. Op. cit. 2004. p. 04.

57) Butler J. Lenguaje, poder e identidad. Madrid, Editorial Síntesis [Trad.: Javier Sáez y Beatriz Preciado]; 2004.

58) Connell RW. Políticas da Masculinidade. Educação \& Realidade. 1995;20(2):1995 185-206.

59) Carrara S, Simões JA. Sexualidade, cultura e política: a trajetória da identidade homossexual masculina na antropologia brasileira. Cadernos Pagu. 2007;28: 65-99.

60) Neves MCP. Sentidos da vulnerabilidade: característica, condição, princípio. Revista Brasileira de Bioética. 2006; 2(2); 2006: 157-72.

61) Godoi AMM. Criminalização da transmissão sexual do HIV: uma abordagem bioética [Tese]. Brasília: Universidade de Brasília, Bioética; 2013.

62) Godoi AMM Op. cit. 2013. p. 157-72

63) Beauchamp T, Childress J. Principle of Biomedical Ethics. 5a edition. Oxford: Oxford University Press; 2002. p. 63.

64) Neves MCP. Op.cit. 2006. p. 34.

65) Ten Have H, Jean M. eds. The UNESCO universal declaration on bioethics and human rights: Background, principles and application. Unesco; 2009.

66) Neves MCP. Op.cit. 2006.p.36.

67) Godoi AMM. Op.cit. 2013.p.71.

68) Neves MCP. Op.cit. 2006.p. 36.

69) Neves MCP. Op.cit. 2006.p. 37. 
70) Godoi AMM. Op.cit. 2013.p. 72.

71) Godoi AMM Op. cit. 2013. p.24.

72) Godoi AMM Op. cit. 2013. p. 39.

73) Junges JR. Vulnerabilidade e saúde: limites e potencialidades das políticas públicas. In: Barchifontaine CP; Zoboli ELCP. Bioética, vulnerabilidade e saúde. Aparecida: Ideias \& Letras, Centro Universitário São Camilo; 2007. p. 111.

74) Almeida DL. Suscetibilidade: novo sentido para a vulnerabilidade. Revista Bioética. 2010; 18(3): 537-48.

75) Barbosa S. Bioética no Estado Brasileiro: situação atual e perspectivas futuras. Brasília: Editora Universidade Brasília; 2010.

76) Garrafa V, Pessini L. (Org). Bioética, poder injustiça. São Paulo. Loyola; 2003.

77) Garrafa V, Pessini L. Op.cit. 2003. p. 51.

78) Garrafa V. Bioética, poder e injustiça: por uma ética de intervenção; 2002. [citado em 2014 out. 12]. Disponível em htpp: //portal.revistas.bvs.br .

79) Porto D, Garrafa V. Bioética de intervenção: considerações sobre a economia de mercado. Revista Bioética. 2009;13(1).

80) Costa CL, Avila E. Gloria Anzaldua, a consciência mestiça e o 'feminismo da diferenc $\square$ a'. Estudos Feministas; 2005. n. 13 (3), p. 691-703.

81) Piscitelli, A. Interseccionalidades, categorias de articulação e experie $\square$ ncia de migrantes brasileiras. Sociedade e Cultura. 2008; 11(2): 263-74.

82) Paiva V. Sem mágicas soluções: a prevenção e o cuidado em HIV/AIDS e o processo de emancipação psicossocial. Interface. 2002; 6(11):25-38.

83) Mann J, Tarantola DJM, Netter T. Como avaliar a vulnerabilidade à infeção pelo HIV e AIDS. In: Parker R. A AIDS no mundo. Rio de Janeiro: Relume Dumará; 1993. p. 276-300.

84) Ayres JRCM. O conceito de vulnerabilidade e as práticas de saúde: novas perspectivas e desafios. In: Czeresnia D, Freitas CM, (org.).Promoção da saúde: conceitos, reflexões, tendências. Rio de Janeiro: Fiocruz; 2003. p. 117-39.

85) Meyer DEE, de Mello DF, Valadão MM, Ayres, JRCM. Você aprende. A gente ensina? Interrogando relações entre educação e saúde desde a perspectiva da vulnerabilidade - "You learn, we teach"? Questioning relations between education. Cad. Saúde Pública; 2006; 22(6):1335-1342.

86) Ayres JRCM. Repensando conceitos e práticas em saúde pública. Prevenção à AIDS: limites e possibilidades na terceira década. ABIA; 2002. p.12-19. 
87) Parker R, Camargo Jr., KR. Pobreza e HIV/AIDS: aspectos antropológicos e sociológicos. Poverty and HIV/AIDS: anthropological and sociological aspects. Cad. Saúde Pública.2000;16(Sup 1):89-102.

88) Tulloch J, Lupton D. Risk and every day life. London; 2003. p. 22.

89) Ayres, JRCM, et al. Risco, vulnerabilidade e práticas de prevenção e promoção da saúde. Saúde em Debate. Hucitec; Fiocruz. 2006;170:375-417.

90) Leavell HR, et.al. Medicina Preventiva. McGraw-Hill: [editor desconhecido]; 1976.

91) Ayres JRCM. Práticas educativas e prevenção de HIV/Aids: lições aprendidas e desafios atuais. Interface Comunicação, Saúde e Educação. 2002;6(11):11-24.

92) Czeresnia D, Freitas CM (org.). Promoção da Saúde: conceitos, reflexões, tendências. Rio de Janeiro: Ed. Fiocruz; 2003. p. 39-53.

93) Sícoli JL, Paulo RN. Promoção de saúde: concepções, princípios. Interface Comunicação, Saúde, Educação; 2003. p. 101-22.

94) Mann J, Tarantola DJM, Netter, TW (orgs.). A aids no mundo. Rio de Janeiro: Relume Dumará; ABIA; IMS/UERJ;1993.

95) Parker R. The negotiation of difference: Male prostitution, bisexual behavior and HIV transmission in Brazil. In: Sexuality, Politics and AIDS in Brazil. Daniel H, Parker, R. London England Falmer Press; 1993. p. 85-96.

96) Ayres JRCM. Epidemiologia sem números: outras reflexões sobre a ciência epidemiológica, a propósito da AIDS. Seminário Epidemiologia Social da AIDS. Rio de Janeiro. ABIA/IMS-UERJ; 1994. p. 8-19.

97) Ayres JRCM, França JI, Calazans G. Vulnerabilidade e Prevenção em Tempos de AIDS. In Barbosa RM, Richard P (org.). Sexualidades pelo Avesso: direitos, Identidades e Poder. São Paulo: Editora 34; 1999. p. 50-72.

98) Confederação Nacional de Trabalhadores em Educação. Jornal on line da Confederação Nacional de Trabalhadores. LGBT em pauta. Brasil [atualizado em 2014 Ago. 08; citado em 2010 abril 30] Disponível em: http://www.cnte.org.br.

99) Confederação Nacional de Trabalhadores em Educação. Op.cit. 2010. p. 4.

100) Temporão, JG (Ministro da Saúde, anfiteatro Emilio Ribas - sede do Ministério da Saúde - DF). Fala proferida durante o lançamento da campanha: "Sou Travesti. Tenho Direito de Ser Quem Sou"; 2010 janeiro 29.

101) Oliveira K. Pró Parnaíba sua revista eletrônica. Brasil se mobiliza pela visibilidade positiva das travestis [Internet]; 2011 jan. 29 [citado em 2014 out. 18]. Disponível em http://www.proparnaiba.com/diversosphb/brasil-se-mobiliza-pela-visibilidade-positivadas-travestis-1296242962.html: 
102) Pelucio, L. Nos nervos, na carne e na pele. Uma etnografia sobre prostituição travesti e modelo preventivo de AIDS. [Tese]. São Carlos/SP: Programa de Pós Graduação em Ciências Sociais, Universidade Federal de São Carlos; 2007. p. 146.

103) Paiva V. Op.cit. 2002. p. 25-38.

104) Teixeira F. Projeto Estratégico para sensibilização de travestis e transexuais para a realização do teste rápido para a detecção de anticorpos anti-HIV [Internet]. Mensagem para Juny Kraiczyk. 2014 Abril 24 [citado em 2014 Nov. 23. [5 parágrafos].

104) Pelucio L. Op.cit 2007.p.102.

105) Teixeira F. Op.cit. 2014. p. 23.

106) Ministério da Saúde (BR). Secretaria de Vigilância em Saúde. Programa Nacional de DST e Aids. Manual de adesão ao tratamento para pessoas vivendo com HIV e Aids. Serie A. Normas e Manuais Técnicos n. 84. Brasília: Ministério da Saúde; 2008. p. 130.

107) Barreda V, Isnardi V. Travestis y prevención del vih/sida: un escenario de categoría en crisis. In: Cáceres C, et al. Sexualidad, estigma y derechos humanos. Desafíos para el acceso a la salud en América Latina. Lima: FASPA/UPCH; 2006. p.167-176.

108) Garrafalo R., Deleon J., Osmer E., Doll M., Harper, GW. Overlooked, misunderstood and risk. Exploring he lives and HIV risk of ethnic minority male-totransgender youth. Journal of Adolescent Health. 2008;38(3):230-236.

109) Caprara A, Rodrigues J. A relação assimétrica médico-paciente: repensando o vínculo terapêutico. Ciência e Saúde Coletiva. 2004;9(1):139-146.

110) Garrafa V; Prado, M. Saúde pública, justiça e mercado - um olhar bioética sobre interesses inconciliáveis. The Magazine of the Pan American Health Organization. OPS/OMS.2002;7(1):30-40.

111)Amuschastegui A. Processos Subjetivos de Cidadania in México: Heteronormatividade e Saúde. In: Carceres CF, Careaga G, Frasca T, Pecheny (edit). Sexualidade estigma y Direchos humanos - desafios para el acesso a la salud em America Latina. Lima: FASPA/UPNC; 2006.

112) Pelucio L. Op. cit. 2007. p. 118-19.

113) Lorenzo C; Ferreira O. Políticas públicas de saúde e forma cotidianas de vida: reflexão entre biopoder e bioética. Brasil [data desconhecida]. 4 p.

114) Venturi G. Diversidade Sexual e Homofobia no Brasil. Intolerância e respeito às diferenças sexuais. São Paulo. Fundação Perseu Abramo; 2010. 
115) Secretaria de Direitos Humanos da Presidência da República (BR), Coordenação de Promoção dos Direitos LGBT. Relatório sobre violência homofóbica no Brasil. Brasília: Secretaria de Direitos Humanos da Presidência da República; 2012.

116) Secretaria de Direitos Humanos da Presidência da República (BR), Coordenação de Promoção dos Direitos LGBT. Relatório sobre violência homofóbica no Brasil. Brasília: Secretaria de Direitos Humanos da Presidência da República; 2012.

117) Peres WS. Travestis, transexuais e transge $\square$ neros: novas imagens e expressões da subjetividade. Conselho Regional de Psicologia da 6a Região (org). Caderno Temático Psicologia e diversidade sexual. 2013:78-89

118) Trevisan JS. Devassos no Paraíso: a homossexualidade no Brasil, da colônia à atualidade. 6a. ed. Rio de Janeiro (Brasil): Record; 2007.

119) Facchini R. Histórico da luta de LGBT no Brasil. In: Conselho Regional de Psicologia da $6^{\text {a }}$ Região (org). Psicologia e diversidade sexual. Conselho Regional de Psicologia da 6a Região. São Paulo; 2011. p. 13.

120) Daniel H, Parker R. AIDS: a terceira epidemia. São Paulo: Iglu Editora; 1991.

121) Trevisán JS. Perverts in paradise. London: GMP, 1986 In: Landau C. A Aids mudou de cara: memória coletiva e novas oportunidades para o ativismo da Aids no Brasil. Plural, Revista do de Pós Graduação em Sociologia da USP, São Paulo (Brasil). 2011;17(2):11-44.

122) Terto JV. Reinventando a vida: histórias sobre homossexualidade e AIDS no Brasil. [Tese]. Universidade Estadual do Rio de Janeiro, Saúde Coletiva. Rio de Janeiro; 1997.

123) Terto JV. Homossexualidade e saúde: desafios para a terceira década de epidemia de hiv/aids. Horizontes Antropológicos, Porto Alegre, ano 8, n. 17; 2002. p. 147-158.

124) Ministério da Saúde (BR), Secretaria de Vigilância, Departamento de DST, Aids e Hepatites Virais. Boletim epidemiológico AIDS e DST, Brasilia: Ministério da Saúde; 2013.

125) Bastos FI. Taxas de infecção de HIV e sífilis e inventário de conhecimento, atitudes e práticas de risco relacionadas às infecções sexualmente transmissíveis entre usuários de drogas em 10 municípios brasileiros. [Relatório técnico]. Ministério da Saúde (BR). Departamento de DST, Aids e Hepatites Virais; 2009.

126) Szwarcwald CL. et al. HIV-related risky practices among Brazilian Young men, 2007. Cad. Saúde Pública. 2011;27 Suppl 1:19-26.

127) Szwarcwald CL. Taxas de prevalência de HIV e sífilis e conhecimento, atitudes e práticas de risco relacionadas às infecções sexualmente transmissíveis nos grupos das 
mulheres profissionais do sexo, no Brasil. [Relatório técnico]. Ministério da Saúde (BR). Departamento de DST, Aids e Hepatites Virais; 2009.

128) Giami A., Le Bail J.: Infection à VIH et IST dans la population "trans": une revue critique de la littérature internacional. Revue d'Épidémiologie et de Santé Publique; 2011.p.59 (sous presse).

129) Boehmer U. Twent years of public health research: inclusion of lesbian, gay, bisexual, and transgender populations. American Journal of Public Health. 2002;92: 1125- 30 .

130) Sousa F; Ferreira L; Sá JB. Estudo descritivo da homofobia e vulnerabilidade ao HIV/Aids das travestis da Região Metropolitana do Recife. Brasil. Ciênc. saúde coletiva. 2013;18(8):2239-2251.

131) Benedetti MC. Toda feita: o corpo e o gênero das travestis. Editora Garamond; 2005.

132) Cruz EF. Banheiros, travestis, relações de gênero e diferenças no cotidiano da escola. Rev. Psicol. Política. São Paulo. 2011;11(21):73-90.

133) Peres WS. Subjetividade das travestis brasileiras: da vulnerabilidade da estigmatização à construção da cidadania. Universidade do Estado do Rio de Janeiro. Instituto de Medicina Social; 2005.

134) Carrara S; Facchini R; Simões J; Ramos S. Política, direitos, violência e homossexualidade: pesquisa 9a Parada do Orgulho GLBT - Rio de Janeiro - 2005. Rio de Janeiro: Universidade do Estado do Rio de Janeiro. Centro de Estudos e Pesquisa em Saúde Coletiva. Instituto de Medicina Social; 2006.

135) Carrara S., et al. Política, Direitos, Violência e Homossexualidade: Pesquisa $5^{\text {a }}$ Parada da Diversidade - Pernambuco. Rio de Janeiro. Centro Latino-Americano em Sexualidade e Direitos Humanos (CLAM)/UERJ. 2006;6:1-90.

136) Secretaria de Direitos Humanos da Presidência da República - SDH/PR (BR). Coordenação de Promoção dos Direitos LGBT. Relatório sobre violência homofóbica no Brasil [internet] Brasília: Secretaria de Direitos Humanos da Presidência da República; c2012. [citado em 2013 out. 6]. Disponível em: http://www.sdh.gov.br/assuntos/lgbt/pdf/relatorio-violencia-homofobica-ano-2012.

137) Kerr L. Comportamento, atitudes, práticas e prevalência de HIV e sífilis entre homens que fazem sexo com homens (HSH) em 10 cidades brasileiras. Brasilia: Ministério da Saúde; 2009.

138) Ministério da Saúde (BR). Secretaria de Vigilância em Saúde. Departamento de DST, Aids e Hepatites Virais. Pesquisa de Conhecimentos, Atitudes e Práticas na População Brasileira de 15 a 64 anos 2008. Brasília; 2008. 
139) Gupta GR, Parkurst JO; Ogden, JA. The Lancet HIV Prevention: Abordagens estruturais para a prevenção do HIV. International Center for Research on Women, Washington, DC, USA; 2008.

140) Kincaid, MMK. Dr. PH, MS (Team Leader); Hannah C; Fortune-Greeley, MPH; Nancy W; Alvey, MS. Diagnóstico de situación en el ámbito de politicas relacionadas con VIH en Centro América [internet] Centro América: USAID Programa Regional de VIH/SIDA para Centro América; c2010 [citado em 2014 março 4]. Disponível em: http://www.usaid.gov/sites/default/files/documents/1862/HIV\%20Assessment\%20Repo rt_Central\%20America_FNL_SPAN_12-6-12.pdf.

141) Organización Panamericana de la Salud (OPAS). Por la salud de las personas trans: Elementos para el desarrollo de la atención integral de personas trans y sus comunidades en Latinoamérica y el Caribe; 2011. p. 12

142) Hernández FM; Guardado ME, Paz-Bailey G. Encuesta centroamericana de vigilancia de comportamiento sexual y prevalencia de VIH/ITS en poblaciones vulnerables (ECVC), subpoblación transgénero, transexual y travesti. UVG/Tephinet. 2010;12:1-56.

143) Mazariegos L. Estudio exploratório sobre conocimientos, actitudes, percepciones, prácticas sexuales y prevalencia ante el VIH de la comunidad trans trabajadora sexual de Ciudad de Guatemala. [internet] Guatemala: Organización Trans Reinas de la Noche; Guatemala; c2010 [citado em 2014 março 18]. Disponível em http://www.pasca.org/sites/default/files/2010_Guatemala_estudioexploratorio_Trans_1. pdf.

144) Ministerio de Salud (Argentina), ONUSIDA; Organización Panamericana de la Salud. Salud, VIH-Sida y Sexualidad Trans: atencion de la salud de personas travestis y transexuales, estudio de soroprevalencia de VHI en personas trans. Buenos Aires; Organización Panamericana de la Salud; 2008.

145) Henandez I \& Schneider F. Caracterización de la Vulnerabilidad individual y grupal de personas Trans de la Región Metropolitana, con ênfase en aquellas que exercen el comercio sexual. Chile. [Centro de Estudios de la Sexualidad, CES, Movimento Unificado de Minorías Sexuales, MUMS, Agrupación de Personas Transgéneras] Amanda Jofré; 2009.

146) USAID. Del Pueblo de los Estados Unidos de America. Diagnóstico de necesidades de salud y servicios disponibles para la población trans de Panamá [Internet]. Panamá; c2013 [citado em 2014 março 4] Disponível em: http://www.aidstarone.com/sites/default/files/AIDSTAR_Panama_Assessment_SPAN.pdf.

147) Tooru N; Dom Operario; JoAnne, K. HIV Risk Behaviors Among Male-to-Female Transgender Persons of Color in San Francisco Am J Public Health [internet]. São 
Francisco; c2004 [citado em 2013 out. 12]. Disponível em: http://www.ncbi.nlm.nih.gov/pmc/articles/PMC1448420.

148) Simon PA; Reback CJ; Bemis CC. HIV prevalence and incidence among male-tofemale transsexuals receiving HIV prevention services in Los Angeles County. AIDS. PubMed. 2000;14:2953-2955.

149) Herbst JH., et al. Estimating HIV prevalence and risk behaviors of transgender persons in the United States: a systematic review. Aids and Behav. 2008;12(1):1-17.

150) Hwahng SJ, Nuttbrock L. Sex Workers, fem queens, and cross-dressers: Differential marginalizations and HIV vulnerabilities among three ethnocultural maleto-female transgender communities in New York City. Sexuality Research \& Social Policy. 2007;4(4):36-59.

151) Operario D; Soma T; Underhill K. Sex Work and HIV Status Among Transgender Women: Systematic Review and Meta-Analysis. JAIDS Jounal of Acquired Immune Deficiency Syndromes.2008;48(1): 97-103.

152) Spizzichino, L., et.al. HIV infection among foreign people involved in HIV-related risk activities and attending an HIV reference centre in Rome: The possible role of counselling in reducing risk behaviour. AIDS Care: Psychological and Socio-medical Aspects of AIDS/HIV. 1998;10:473-480.

153) Mello, L; Perilo, M; Braz, CA, Pedrosa, C. Políticas de saúde para lésbicas, gays, bissexuais, travestis e transexuais no Brasil: em busca de universalidade, integralidade e equidade. Sexualidad, Salud y Sociedad-Revista Latinoamericana. 2011;9:7-28.

154) Jarbas Barbosa. Transexuais e travestis poderão usar nome social em cartão SUS. [internet]. Portal Brasil. Brasília. c29/01/2013 [citado em 2014 março 20]. Disponível em http://www.brasil.gov.br/cidadania-e-justica/2013/01/transexuais-e-travestispoderao-usar-nome-social-em-cartao-do-sus.

155) Simpson K. Agencia de Noticias da Aids. Dia da Visibilidade Trans: vencedora do Prêmio Direitos Humanos, ativista Keila Simpson afirma que a luta hoje é pelo nome civil [internet]. São Paulo (BR).; c.29/01/2014 [citado em 2014 março 20]. Disponível em: http://www.agenciaaids.com.br/noticias/interna.php?id=21865.

156) Rios RR. O conceito de homofobia na perspectiva dos direitos humanos e no contexto dos estudos sobre preconceito e discriminação. In: Rios RR (org). Em defesa dos direitos sexuais. Porto Alegre: Editora Livraria do Advogado; 2007.

157) Carrara S, Vianna ABR. “Tá lá um corpo estendido no chão: a violência letal contra travestis no município do Rio de Janeiro". Physis: Rev. Saúde Coletiva. Rio de Janeiro. 2006;16(2):233-249.

158) Duarte MJO. Políticas Públicas para a população de Lésbicas, Gays, Travestis e Transexuais (LGBT).Uma questão de Direitos Humanos e de Cidadania. Advir; 2012. 
159) Russell N. Intervenções de Prevenção de HIV/Aids em HSH, Gays e Travestis no Brasil (2006 - 2012): Uma Revisão Sistemática. Brasil. Ministério de Saúde, Departamento de DST, Aids, e Hepatites Virais. 2012.

160) Peres W. Subjetividades das Travestis Brasileiras: Interfaces entre estigmas e construção da cidadania. Seminário Internacional Fazendo Gênero 7: Gênero e Preconceit; 2006; Florianópolis: Sexualidades, corporalidades e transgêneros, narrativas fora da ordem; 2006.

170) Da Transfobia à Cidadania XIX ENTLAIDS: Brasília, 04 a 08 de novembro de 2012. Relatório Final [Internet] Brasília, 2012 [citado em 2014 out. 10]. Disponível em: http://www.abglt.org.br/docs/Relatorio-XIX-ENTLAIDS_2012.pdf.

171) Carvalho GCM. Participação da comunidade na saúde. Passo Fundo: IFIBE; CEAP; 2007.p. 259.

172) Veras A. Vulnerabilidades, demandas de saúde e acesso a serviços da população de travestis e transexuais do estado de São Paulo. Faculdade de Ciências Médicas da Santa Casa de São Paulo (FCMSCSP), Fundação Arnaldo Vieira de Carvalho; 2013.

173) Serrano PE. Carta Capita. Prostituição e direito à saúde. [Internet]. Brasil; c2013 [citado 2015 Out. 10]. Disponível em: http://www.cartacapital.com.br/politica/prostituicao-e-direito-a-saude-737.html

174) Beloqui J, Terto JV. A prevenção à AIDS no governo Dilma e a censura dos vídeos da campanha de Carnaval 2012. [internet] (s/d). [citado em 2014 Out. 13]. Disponível em: www.clam.org.br/publique/media/artigoveriano.pdf.

175) Schramm FR; Barboza HH, Guimarães A. Amoralidade da transexualidade: aspectos bioéticos e Jurídicos - The morality of transsexuality: bioethical and Juridical aspects. Revista Redbioética/UNESCO. 2011;66:74.

176) Montagner MA. Sociologia médica, sociologia da saúde ou medicina social? Um escorço comparativo entre França e Brasil. Saúde Sociedade. 2008;17:193-210.

177) Pasini E. Corpos em Evidência, pontos em ruas, mundos em pontos: a prostituição na região da Rua Augusta em São Paulo [Dissertação]. Campinas. Universidade Estadual de Campinas. Programa de Pós-Graduação em Antropologia Social; 2000.

178) Sabatine TT. Travestis, territórios e prevenção de AIDS numa cidade do interior de São Paulo. [Dissertação]. São Paulo. Universidade Estadual Paulista, Faculdade de Filosofia e Ciências de Marília; 2012.

179) Paiva V. Relatório da Faixa $D$ na Conferência de Internacional de AIDS Melbourne AUS, 2014 [Internet] Brasil; c2014 [citado em 2014 outubro 9]. Disponível em http://oquenostiraosono.tumblr.com/post/93832757826/relatorio-da-faixa-d-naconferencia-de-internacional-de. 
180) Bhabha, H. O local da cultura. Belo Horizonte: Editora da UFMG; 2005. p. 63.

181) Pelucio, L. Op.cit 2007.p. 23

182) Câmera C, Lima, RM. Histórico das ONGs/Aids e sua contribuição no campo das lutas sociais. ABONG: Cadernos ABONG "Direitos Humanos, Cidadania e Aids". São Paulo: Ed. Autores Associados. 2000;28:29.

183) Souza C. Políticas públicas: questões temáticas e de pesquisa. Caderno CRH, Salvador. 2003;39:11-24.

184) Zinn MB. Chicano Men and Masculinity. Journal of Ethnic Studies. 1982;10 (2):29-44.

185) Davis A. Women, Race, and Class. New York: Vintage; 1983.

186) Araújo AC, Lotufo NF. A nova classificação americana para os transtornos mentais: o DMS-5. Jornal de Psicanálise. 2013;46(85):99-116.

187) Seara LN. A promoção dos direitos humanos no campo da AIDS: estudo de caso da Assessoria Jurídica do Grupo de Apoio à Prevenção à AIDS da Bahia (GAPA/BA). [Mestrado]. Salvador. Universidade Federal da Bahia, Escola de Administração; 2011

188) Departamento de Apoio a Gestão Participativa, Secretaria de Gestão Estratégica e Participativa. Ministério da Saúde. Saúde da população de gays, lésbicas, bissexuais, travestis e transexuais. Rev Saúde Pública. 2008;42(3):570-3.

189) Fraser N. Rethinking recognition. New Left Review. 2000;3:107-120.

190) Câmara, C (org.). Aids e desenvolvimento, entrecruzando agendas. GAPA/BA: Salvador; 2004.

191) Arilha M; Lapa TS; Pisaneschi, TC (orgs.). Transexualidade, travestilidade e direito à Saúde. Coleção Democracia, Estado Laico e Direitos Humanos. São Paulo; Oficina Editorial; 2010. p. 252.

133) Peres WS. Subjetividade das travestis brasileiras: da vulnerabilidade da estigmatização à construção da cidadania [dissertação]. Universidade do Estado do Rio de Janeiro. Instituto de Medicina Social; 2005.

193) Moscheta MS. Responsividade como recurso relacional para a qualificação da assistência a saúde de lésbicas, gays, bissexuais, travestis e transexuais. [Dissertação]. Universidade de São Paulo; 2011.

194) Louro G. Gênero e sexualidade: pedagogias contemporâneas. Pro-Posições. 2008;19(2):56p. 
195) Facchini R. Sopa de letrinhas?: movimento homossexual e produção de identidades coletivas nos anos 90. Editora Garamond; 2005.

196) Coan DL; Schrager W; Packer T. The Role of Male Sexuals Partners in HIV Infection Among Male-to-Female Transgendered Individuals. In: Bockting W, Avery E, eds. Transgender Health and HIV Prevention: Needs assessment studies from transgender communities across United States. Binghamton, NY: The Haworth Medical Press; 2005. p. 21-30.

Operario D; Burton J; Underhill K; Sevelius J. Men Who Have Sex with Transgender Women: Challenges to Category-based HIV Prevention. AIDS \& Behavior. 2008;12:18- 26.

197) Bockting W; Miner M; Rosser BRS. Latino Men's Sexual Behavior with Transgender Persons. Archives of Sexual Behavior 2007; 36:778-86.

198) Cardoso JAM. Educação e as Práticas de Saúde Escola Politécnica de Saúde Joaquim Venâncio (Org.). Trabalho, Educação e Saúde: reflexões críticas de Joaquim Alberto Cardoso de Melo. Rio de Janeiro: EPSJV; 2007

199) Ministério da Saúde (BR) Secretaria de Atenção à Saúde. Humaniza SUS. Acolhimento nas práticas de produção da saúde. 2. ed. Brasília; 2008.

200) Pereira, IB, Lima, JCF. Dicionário da educação profissional em saúde. Rio de Janeiro: EPSJV; 2008 p. 74. 


\begin{tabular}{|c|c|c|c|c|}
\hline \multicolumn{5}{|c|}{$\begin{array}{l}\text { ATIVIDADES PROPOSTAS PARA TRAVESTIS, GAYS E HSH } \\
\text { NOS PLANOS ESTADUAIS DE ENFRENTAMENTO AO HIV/AIDS ENTRE GAYS, HSH E } \\
\text { TRAVESTIS ENTRE OS ANOS DE } 2008 \text { A } 2012\end{array}$} \\
\hline Educação em Saúde & $\begin{array}{l}\text { Integralidade da } \\
\text { assistência ou } \\
\text { no cuidado }\end{array}$ & $\begin{array}{l}\text { Fortaleciment } \\
\text { o e } \\
\text { participação } \\
\text { da sociedade } \\
\text { civil }\end{array}$ & Comunicação. & $\begin{array}{c}\text { Ações específicas } \\
\text { para travestis que } \\
\text { ainda nao foram } \\
\text { colocadas nas } \\
\text { demais categorias. }\end{array}$ \\
\hline $\begin{array}{c}\text { Capacitação e sensibilização } \\
\text { de profissionais de saúde } \\
\text { dos serviços de diagnostico } \\
\text { e aconselhamento em } \\
\text { DST/HIV/aids sobre } \\
\text { especificidades do } \\
\text { acolhimento aos gays, HSH } \\
\text { e travestis, diversidade, } \\
\text { orientação sexual e } \\
\text { identidade de gênero, } \\
\text { visando a garantir a } \\
\text { participação dos mesmos } \\
\text { nas diversas ações }\end{array}$ & $\begin{array}{c}\text { Realizar } \\
\text { reuniões com } \\
\text { Conselhos de } \\
\text { Saúde, } \\
\text { Conselhos de } \\
\text { Gestores de } \\
\text { Saúde e } \\
\text { Gerentes de } \\
\text { Unidades de } \\
\text { Saúde com a } \\
\text { participação das } \\
\text { OSC sobre a } \\
\text { importância da } \\
\text { criação de } \\
\text { horários } \\
\text { alternativos de } \\
\text { funcionamento } \\
\text { para atender ao } \\
\text { segmento de } \\
\text { gays, HSH e } \\
\text { travestis. }\end{array}$ & $\begin{array}{c}\text { Mapear, } \\
\text { consolidar e } \\
\text { unificar os } \\
\text { dados sobre as } \\
\text { organizações } \\
\text { que } \\
\text { desenvolvem } \\
\text { trabalhos com } \\
\text { HSH, gays e } \\
\text { travestis } \\
\text { (GRS.). }\end{array}$ & $\begin{array}{l}\text { Garantir } \\
\text { campanha de } \\
\text { comunicação } \\
\text { de massa } \\
\text { (radio) e } \\
\text { propaganda de } \\
\text { divulgação } \\
\text { prevenção/ } \\
\text { homofobia }\end{array}$ & $\begin{array}{c}\text { Divulgar a Portaria } \\
\text { no 675/MS, de } \\
\text { 30/06/2006, que } \\
\text { garante o uso do } \\
\text { nome social nos } \\
\text { serviços de saúde. }\end{array}$ \\
\hline $\begin{array}{l}\text { Acolhimento pelo } \\
\text { profissional de saúde, } \\
\text { humanização do } \\
\text { atendimento, atendimento } \\
\text { interdisciplinar }\end{array}$ & $\begin{array}{c}\text { Realizar e } \\
\text { fortalecer } \\
\text { parceria com os } \\
\text { órgãos } \\
\text { formadores de } \\
\text { profissionais } \\
\text { (saúde/educação } \\
\text { /assistência, } \\
\text { etc.) para } \\
\text { realização de } \\
\text { ações } \\
\text { preventivas nas } \\
\text { temáticas } \\
\text { relacionadas ao } \\
\text { enfrentamento } \\
\text { das } \\
\text { DST/HIV/aids e } \\
\text { hepatites. }\end{array}$ & $\begin{array}{c}\text { Mapear, } \\
\text { consolidar e } \\
\text { unificar os } \\
\text { dados sobre as } \\
\text { organizações } \\
\text { que } \\
\text { desenvolvem } \\
\text { trabalhos com } \\
\text { HSH, gays e } \\
\text { travestis }\end{array}$ & $\begin{array}{l}\text { Realizar 01 } \\
\text { edital de } \\
\text { seleção de } \\
\text { projetos da } \\
\text { sociedade civil } \\
\text { voltadas para a } \\
\text { mobilização } \\
\text { dos meios de } \\
\text { comunicação } \\
\text { do Estado } \\
\text { relacionado as } \\
\text { vulnerabilidad } \\
\text { es do } \\
\text { HIV/Aids e a } \\
\text { homofobia. }\end{array}$ & $\begin{array}{c}\text { Apoiar as OSC } \\
\text { para a inclusão no } \\
\text { SUS do } \\
\text { procedimento de } \\
\text { implantação de } \\
\text { prótese, a fim de } \\
\text { reduzir os danos } \\
\text { causados pelo uso } \\
\text { inadequado de } \\
\text { silicone industrial. }\end{array}$ \\
\hline $\begin{array}{c}\text { Capacitação dos } \\
\text { profissionais dos serviços de } \\
\text { saúde em relação à } \\
\text { utilização de silicone } \\
\text { industrial e hormonizac } \square \text { ão } \\
\text { (tratamento, efeitos } \\
\text { colaterais e risco) na ótica } \\
\text { da reduc } \square \text { ão de danos e } \\
\text { com a participação de }\end{array}$ & $\begin{array}{l}\text { Constituição de } \\
\text { grupo de } \\
\text { trabalho } \\
\text { formado por } \\
\text { representantes } \\
\text { do Governo, da } \\
\text { Sociedade Civil } \\
\text { e de Instituições } \\
\text { que trabalham } \\
\end{array}$ & $\begin{array}{l}\text { Realizar duas } \\
\text { reuniões } \\
\text { anuais } \\
\text { ampliadas } \\
\text { com foco no } \\
\text { dialogo e } \\
\text { articulação } \\
\text { entre } \\
\text { representantes }\end{array}$ & $\begin{array}{l}\text { Realizar 02 } \\
\text { capacitações } \\
\text { de } \\
\text { representantes } \\
\text { de gays, HSH } \\
\text { e travestis em } \\
\text { "relações } \\
\text { publicas" e } \\
\text { "estratégia }\end{array}$ & $\begin{array}{c}\text { Produzir e } \\
\text { distribuir material } \\
\text { educativo contendo } \\
\text { informações em } \\
\text { todos os } \\
\text { municípios do } \\
\text { Estado da Portaria } \\
\text { GM 675/06, que } \\
\text { trata da inclusão do } \\
\end{array}$ \\
\hline
\end{tabular}




\begin{tabular}{|c|c|c|c|c|}
\hline representantes das travestis. & $\begin{array}{l}\text { na área de } \\
\text { avaliação de } \\
\text { política } \\
\text { publicas, em } \\
\text { cada esfera do } \\
\text { Governo }\end{array}$ & $\begin{array}{l}\text { do movimento } \\
\text { de travestis, } \\
\text { gestores, } \\
\text { gerentes e } \\
\text { profissionais } \\
\text { do serviço de } \\
\text { saúde, para } \\
\text { discutir } \\
\text { assuntos como } \\
\text { inclusão das } \\
\text { especificidade } \\
\text { s das travestis, } \\
\text { acesso ao } \\
\text { proctologista, } \\
\text { urologista, } \\
\text { hormonioterap } \\
\text { ia e } \\
\text { informações } \\
\text { sobre os riscos } \\
\text { de uso de } \\
\text { silicone } \\
\text { industrial e o } \\
\text { acesso a } \\
\text { próteses de } \\
\text { silicone }\end{array}$ & $\begin{array}{c}\text { comunicacion } \\
\text { ais". }\end{array}$ & $\begin{array}{l}\text { Nome Social das } \\
\text { travestis nos } \\
\text { prontuários, } \\
\text { formulários e } \\
\text { fichas do Sistema } \\
\text { Único de Saúde. }\end{array}$ \\
\hline $\begin{array}{l}\text { Incluir, nas oficinas para a } \\
\text { atenção básica e no serviço } \\
\text { especializado (assistência/ } \\
\text { acolhimento), a questão da } \\
\text { melhoria do atendimento as } \\
\text { PVHA das populações } \\
\text { contempladas no Plano. }\end{array}$ & $\begin{array}{l}\text { Definição de } \\
\text { técnicos de } \\
\text { referencia nas } \\
\text { equipes dos } \\
\text { SAE para } \\
\text { atender as } \\
\text { demandas de } \\
\text { enfrentamento } \\
\text { das DST/aids } \\
\text { junto a esses } \\
\text { segmentos } \\
\text { populacionais }\end{array}$ & $\begin{array}{c}\text { Criar GÓT. } \\
\text { dentro da SE } \\
\text { que garantam } \\
\text { e possibilitem } \\
\text { outros } \\
\text { espaços, } \\
\text { assegurando a } \\
\text { participação } \\
\text { do Conselho } \\
\text { Estadual de } \\
\text { Saúde, das } \\
\text { OSC } \\
\text { (SOMOS, } \\
\text { Igualdade RS, } \\
\text { RAP, Fórum } \\
\text { ONG/Aids do } \\
\text { RS), } \\
\text { Universidades } \\
\text { (UFRGS, } \\
\text { FURG, } \\
\text { UFPEL), Sec. } \\
\text { de Justiça e } \\
\text { Assistência } \\
\text { Social, Sec. de } \\
\text { Segurança } \\
\text { Publica, Sec. } \\
\text { de Educação. }\end{array}$ & $\begin{array}{c}\text { Elaborar } \\
\text { material de } \\
\text { formação para } \\
\text { os servidores } \\
\text { público sobre } \\
\text { diversidade } \\
\text { sexual e } \\
\text { combate à } \\
\text { homofobia e } \\
\text { transfobia, } \\
\text { Direitos } \\
\text { Humanos e } \\
\text { prevenção as } \\
\text { DST/aids }\end{array}$ & $\begin{array}{c}\text { Produzir e } \\
\text { distribuir material } \\
\text { educativo para } \\
\text { todos os } \\
\text { municípios do } \\
\text { Ceará, contendo } \\
\text { informações da } \\
\text { Portaria GM } \\
\text { 675/06, que trata da } \\
\text { inclusão do Nome } \\
\text { Social (travestis) } \\
\text { nos prontuários, } \\
\text { formulários e } \\
\text { fichas do Sistema } \\
\text { Único de Saúde; }\end{array}$ \\
\hline $\begin{array}{c}\text { Qualificar as equipes } \\
\text { multidisciplinares das } \\
\text { unidades de saúde indicadas } \\
\text { como referencia e } \\
\text { contrarrefere } \square \text { ncia para o } \\
\text { atendimento as demandas da } \\
\text { população de gays, travestis } \\
\text { e outros HSH. }\end{array}$ & $\begin{array}{l}\text { Incorporação na } \\
\text { rede de atenção } \\
\text { as vitimas de } \\
\text { violência } \\
\text { sexual, o } \\
\text { atendimento a } \\
\text { gays, HSH e } \\
\text { travestis, }\end{array}$ & $\begin{array}{c}\text { Criação, } \\
\text { implementaçã } \\
\text { o, } \\
\text { fortalecimento } \\
\text { e mobilização } \\
\text { do movimento } \\
\text { das travestis, } \\
\text { mediante a }\end{array}$ & $\begin{array}{c}\text { Fornecer } \\
\text { apoio técnico } \\
\text { aos } \\
\text { empresários } \\
\text { com negócios } \\
\text { dirigidos a } \\
\text { homossexuais } \\
\text { para a }\end{array}$ & $\begin{array}{l}\text { Realizar duas } \\
\text { reuniões anuais } \\
\text { ampliadas, com } \\
\text { foco no dialogo e } \\
\text { articulação entre } \\
\text { representantes do } \\
\text { movimento de } \\
\text { travestis, gestores, }\end{array}$ \\
\hline
\end{tabular}




\begin{tabular}{|c|c|c|c|c|}
\hline & $\begin{array}{c}\text { articulando os } \\
\text { diversos níveis } \\
\text { de } \\
\text { complexidade } \\
\text { de atenção e } \\
\text { garantir os } \\
\text { procedimentos } \\
\text { de prevenção, } \\
\text { tratamento e } \\
\text { profilaxia para } \\
\text { as DST/AIDS. }\end{array}$ & $\begin{array}{c}\text { realização de } \\
\text { evento/oficina } \\
\text { (com a } \\
\text { presença de } \\
\text { alguma } \\
\text { travesti que } \\
\text { possa } \\
\text { contribuir para } \\
\text { a organização } \\
\text { do movimento } \\
\text { e de } \\
\text { seminário, } \\
\text { visando } \\
\text { fortalecer as } \\
\text { lideranças } \\
\text { existentes e } \\
\text { aproximá-las } \\
\text { dos serviços. }\end{array}$ & $\begin{array}{l}\text { realização de } \\
\text { campanhas e } \\
\text { outras ações } \\
\text { de prevenção } \\
\text { às DST/aids. }\end{array}$ & $\begin{array}{c}\text { gerentes e } \\
\text { profissionais do } \\
\text { serviço de saúde, } \\
\text { trazendo assuntos } \\
\text { como a inclusão } \\
\text { das especificidades } \\
\text { das travestis, } \\
\text { acesso a próteses } \\
\text { de silicone, acesso } \\
\text { a proctologistas, } \\
\text { hormonioterapia } \\
\text { via SUS e } \\
\text { informações sobre } \\
\text { os riscos de uso de } \\
\text { silicone industrial; }\end{array}$ \\
\hline $\begin{array}{l}\text { Realização de cursos de } \\
\text { formação de profissionais } \\
\text { dos setores da saúde, da } \\
\text { educação e da assistência } \\
\text { social para o enfrentamento } \\
\text { da homofobia e atendimento } \\
\text { humanizado a gays, HSH, } \\
\text { travestis e PVHA. }\end{array}$ & $\begin{array}{l}\text { Rever junto aos } \\
\text { CTA/SAE o } \\
\text { horário de } \\
\text { atendimento } \\
\text { para facilitar o } \\
\text { acesso das } \\
\text { travestis ao } \\
\text { diagnostico das } \\
\text { DST/aids. }\end{array}$ & $\begin{array}{l}\text { Estabelecer } \\
\text { parceria entre } \\
\text { Nos e Estado } \\
\text { - incluir todas } \\
\text { as esferas: } \\
\text { saúde, } \\
\text { educação, } \\
\text { cultura, lazer, } \\
\text { juventude, } \\
\text { direitos } \\
\text { humanos, } \\
\text { cidadania e } \\
\text { justiça, } \\
\text { segurança } \\
\text { publica, } \\
\text { trabalho e } \\
\text { desenvolvime } \\
\text { nto social, } \\
\text { órgãos de } \\
\text { classe. }\end{array}$ & $\begin{array}{c}\text { Desenvolver } \\
\text { material } \\
\text { informativo e } \\
\text { de apoio para } \\
\text { a formação de } \\
\text { profissionais } \\
\text { de educação, } \\
\text { abordando as } \\
\text { temáticas } \\
\text { LGBT; }\end{array}$ & $\begin{array}{c}\text { Dar ênfase as } \\
\text { questồ] } \\
\text { aos serviços de } \\
\text { saúde e educação, } \\
\text { incluindo a } \\
\text { divulgação aos } \\
\text { serviços público do } \\
\text { direito à utilização } \\
\text { de seu nome social } \\
\text { (Portaria GM/MS } \\
\text { 675/06). }\end{array}$ \\
\hline $\begin{array}{l}\text { Realizar capacitações sobre } \\
\text { medidas socioeducativas e } \\
\text { de saúde junto a todos os } \\
\text { profissionais do sistema } \\
\text { carcerário, visando à } \\
\text { humanização nos } \\
\text { atendimentos ambulatoriais }\end{array}$ & $\begin{array}{l}\text { Incluir, no Plano } \\
\text { de Integração } \\
\text { entre Vigilância } \\
\text { e Atenção } \\
\text { Básica, ações } \\
\text { educativas na } \\
\text { área, em } \\
\text { conjunto com } \\
\text { outros } \\
\text { programas } \\
\text { prioritários de } \\
\text { saúde. }\end{array}$ & $\begin{array}{c}\text { Seleção e } \\
\text { apoio de } \\
\text { projetos da } \\
\text { sociedade civil } \\
\text { direcionados a } \\
\text { ações } \\
\text { educativas e } \\
\text { preventivas a } \\
\text { populações } \\
\text { vulneráveis }\end{array}$ & $\begin{array}{c}\text { Produção, } \\
\text { veiculação e } \\
\text { qualificação } \\
\text { de campanhas } \\
\text { nacionais e/ou } \\
\text { regionais } \\
\text { dirigidas à } \\
\text { população em } \\
\text { geral. }\end{array}$ & $\begin{array}{l}\text { Realizar duas } \\
\text { reuniões anuais } \\
\text { ampliadas, com } \\
\text { foco no dialogo e } \\
\text { articulação entre } \\
\text { representantes do } \\
\text { movimento de } \\
\text { travestis, gestores, } \\
\text { gerentes e } \\
\text { profissionais do } \\
\text { serviço de saúde, } \\
\text { trazendo assuntos } \\
\text { como a inclusão } \\
\text { das especificidades } \\
\text { das travestis, } \\
\text { acesso a prótese de } \\
\text { silicone, acesso a } \\
\text { proctologistas, } \\
\text { hormonioterapia } \\
\text { via SUS e } \\
\text { informações sobre } \\
\text { os riscos de uso de }\end{array}$ \\
\hline
\end{tabular}




\begin{tabular}{|c|c|c|c|c|}
\hline & & & & silicone industrial. \\
\hline $\begin{array}{c}\text { Realizar seminários e } \\
\text { oficinas visando à } \\
\text { sensibilização e } \\
\text { humanização dos } \\
\text { Profissionais de Saúde do } \\
\text { SUS sobre as } \\
\text { vulnerabilidades dessa } \\
\text { população; }\end{array}$ & $\begin{array}{c}\text { Solicitar 01 } \\
\text { reunião } \\
\text { semestral à } \\
\text { OAB visando a } \\
\text { discussão de } \\
\text { temáticas LGBT } \\
\text { (ES) } \\
\text { Envolvimento } \\
\text { da OAB } \\
\text { também } \\
\text { genérico. }\end{array}$ & $\begin{array}{c}\text { Garantir a } \\
\text { inserção anual, } \\
\text { nos editais de } \\
\text { seleção de } \\
\text { projetos para } \\
\text { OSC, o eixo } \\
\text { Temático que } \\
\text { vise o } \\
\text { desenvolvime } \\
\text { nto de ações } \\
\text { de prevenção e } \\
\text { promoção } \\
\text { voltadas à } \\
\text { população de } \\
\text { gays, HSH e } \\
\text { travestis. }\end{array}$ & $\begin{array}{c}\text { Produzir } \\
\text { material } \\
\text { informativo } \\
\text { sobre } \\
\text { prevenção do } \\
\text { HIV, das DST } \\
\text { e Hepatites } \\
\text { Virais dirigido } \\
\text { a gays, outros } \\
\text { HSH e } \\
\text { travestis. }\end{array}$ & $\begin{array}{l}\text { Criar Grupo de } \\
\text { Trabalho para } \\
\text { elaboração de } \\
\text { protocolo de } \\
\text { hormonioterapia, } \\
\text { reduc } \square \text { ão de danos } \\
\text { sobre silicone e em } \\
\text { outras áreas da } \\
\text { saúde para } \\
\text { população LGBT }\end{array}$ \\
\hline $\begin{array}{l}\text { Apoiar a realização de } \\
\text { capacitações em direitos } \\
\text { humanos, sendo uma em } \\
\text { cada Macro, para } \\
\text { profissionais dessas áreas, } \\
\text { com foco nos direitos } \\
\text { sexuais e reprodutivos, o } \\
\text { enfrentamento da } \\
\text { homofobia e da transfobia; }\end{array}$ & $\begin{array}{c}\text { Solicita a } \\
\text { inclusão de } \\
\text { pautas } \\
\text { semestrais nos } \\
\text { conselhos de } \\
\text { assistência } \\
\text { social, direitos } \\
\text { humanos e } \\
\text { outros, para } \\
\text { mobilização das } \\
\text { questões LGBT. }\end{array}$ & $\begin{array}{c}\text { Apoiar a } \\
\text { organização } \\
\text { da OSC para } \\
\text { defesa dos } \\
\text { Direitos } \\
\text { Humanos e } \\
\text { promoção de } \\
\text { cidadania de } \\
\text { travestis no } \\
\text { Distrito } \\
\text { Federal. }\end{array}$ & $\begin{array}{l}\text { Realizar, no } \\
\text { ano de } 2011, \\
\text { uma } \\
\text { campanha de } \\
\text { comunicação } \\
\text { com a } \\
\text { temática da } \\
\text { diversidade } \\
\text { sexual. }\end{array}$ & $\begin{array}{c}\text { Promoção da } \\
\text { discussão e } \\
\text { inclusão das } \\
\text { especificidades de } \\
\text { saúde das travestis } \\
\text { (acesso a próteses } \\
\text { de silicone, } \\
\text { hormonioterapia } \\
\text { via SUS e riscos do } \\
\text { uso de silicone } \\
\text { industrial) e nas } \\
\text { ações de assistência } \\
\text { e tratamento de } \\
\text { travestis que vivem } \\
\text { com HIV/aids }\end{array}$ \\
\hline $\begin{array}{c}\text { Realizar oficinas de } \\
\text { capacitação em estratégia de } \\
\text { prevenção para o } \\
\text { enfrentamento da epidemia } \\
\text { entre gays, outros HSH e } \\
\text { travestis para as equipes dos } \\
26 \text { municípios com } \\
\text { incentivo, em parceria com } \\
\text { a sociedade civil. }\end{array}$ & $\begin{array}{c}\text { Envolver o } \\
\text { Conselho } \\
\text { Empresarial de } \\
\text { DST/Aids/Hepa } \\
\text { tites Virais na } \\
\text { elaboração de } \\
\text { ações de } \\
\text { prevenção das } \\
\text { DST/aids para } \\
\text { gays, HSH e } \\
\text { travestis. }\end{array}$ & $\begin{array}{c}\text { Criar uma } \\
\text { organização } \\
\text { das OSC com } \\
\text { ações } \\
\text { especificas } \\
\text { para travestis e } \\
\text { mulheres } \\
\text { vivenciando } \\
\text { sua } \\
\text { transexualidad } \\
\text { e, fortalecendo } \\
\text { e ampliando o } \\
\text { protagonismo } \\
\text { das travestis } \\
\text { na definição, } \\
\text { implantação, } \\
\text { monitorament } \\
\text { o e avaliação } \\
\text { de política } \\
\text { publicas } \\
\text { nacionais e } \\
\text { locais de } \\
\text { saúde, de } \\
\text { enfrentamento } \\
\text { da epidemia } \\
\text { do HIV/aids e } \\
\text { de defesa dos } \\
\text { Direitos }\end{array}$ & $\begin{array}{c}\text { Realizar } \\
\text { anualmente } \\
\text { uma } \\
\text { campanha de } \\
\text { prevenção e } \\
\text { testagem para } \\
\text { as hepatites } \\
\text { virais/HIV e } \\
\text { vacinação de } \\
\text { hepatites para } \\
\text { gays, outros } \\
\text { HSH e } \\
\text { travestis }\end{array}$ & $\begin{array}{c}\text { Divulgar junto as } \\
\text { instituic } \square \text { ões } \\
\text { publicas a } \\
\text { legislação nacional } \\
\text { e estadual sobre o } \\
\text { direito ao uso do } \\
\text { nome social das } \\
\text { travestis e } \\
\text { transexuais } \\
\text { (Portaria no } \\
\text { 675/GM, de } 30 \text { de } \\
\text { marco de } 2006 ; \\
\text { Portaria no } \\
\text { 016/2008/GÁS/SE } \\
\text { DUZ; Decreto no } \\
\text { 1.675, de } 21 \text { de } \\
\text { maio de } 2009, \text { do } \\
\text { Governo do Estado } \\
\text { do }\end{array}$ \\
\hline
\end{tabular}




\begin{tabular}{|c|c|c|c|c|}
\hline & & $\begin{array}{l}\text { Humanos e } \\
\text { sexuais. }\end{array}$ & & \\
\hline $\begin{array}{c}\text { Capacitar as OSC para a } \\
\text { produção de conhecimentos } \\
\text { básicos em DST, hepatites e } \\
\text { HIV/aids, com a finalidade } \\
\text { de formar multiplicadores } \\
\text { de praticas corretas de } \\
\text { prevenção e reduc } \square \text { ão de } \\
\text { estigma, dentro dos moldes } \\
\text { da capacitação para } \\
\text { aconselhamento pré- teste. }\end{array}$ & $\begin{array}{l}\text { Implantar ações } \\
\text { intersetoriais } \\
\text { com a atenção } \\
\text { básica, saúde da } \\
\text { mulher, saúde } \\
\text { da família, } \\
\text { saúde do idoso, } \\
\text { área técnica de } \\
\text { pessoas vivendo } \\
\text { com deficiência, } \\
\text { sistema } \\
\text { prisional e } \\
\text { programa do } \\
\text { adolescente para } \\
\text { ações de } \\
\text { prevenção as } \\
\text { DST/aids e } \\
\text { hepatites, junto } \\
\text { aos gays, outros } \\
\text { HSH e travestis. }\end{array}$ & $\begin{array}{c}\text { Mapear as } \\
\text { organizações } \\
\text { não } \\
\text { governamentai } \\
\text { s que } \\
\text { trabalham com } \\
\text { Gays, HSH } \\
\text { e/ou travestis. }\end{array}$ & $\begin{array}{c}\text { Produzir } \\
\text { material } \\
\text { impresso } \\
\text { (banners, } \\
\text { cartazes e } \\
\text { folhetos)que } \\
\text { contribuam } \\
\text { para a redução } \\
\text { da } \\
\text { vulnerabilidad } \\
\text { e às DST } \\
\text { hepatites e } \\
\text { HIV/aids } \\
\text { associadas à } \\
\text { homofobia. }\end{array}$ & $\begin{array}{l}\text { Realização de } 02 \\
\text { reuniões ampliadas } \\
\text { com foco no } \\
\text { dialogo e } \\
\text { articulação entre } \\
\text { representantes do } \\
\text { movimento de } \\
\text { travestis, } \\
\text { gestores, gerentes e } \\
\text { profissionais do } \\
\text { serviço de } \\
\text { saúde, trazendo } \\
\text { assuntos } \\
\text { como inclusão das } \\
\text { especificidades das } \\
\text { travestis, acesso a } \\
\text { próteses } \\
\text { de silicone, acesso } \\
\text { ao proctologistas, } \\
\text { hormonioterapia } \\
\text { via SUS e } \\
\text { informações sobre } \\
\text { os riscos } \\
\text { de uso de silicone } \\
\text { industrial. }\end{array}$ \\
\hline $\begin{array}{l}\text { Capacitar e sensibilizar os } \\
\text { profissionais de saúde dos } \\
\text { serviços de diagnostico e } \\
\text { aconselhamento em } \\
\text { DST/HIV/Aids e Hepatites } \\
\text { Virais sobre especificidades } \\
\text { do acolhimento para gays, } \\
\text { outros HSH e travestis, } \\
\text { como: diversidade, } \\
\text { orientação sexual e } \\
\text { identidade de gênero. }\end{array}$ & $\begin{array}{c}\text { Definir serviços } \\
\text { de referencias } \\
\text { para o } \\
\text { diagnostico, } \\
\text { assistência e } \\
\text { tratamento das } \\
\text { DST/AIDS e } \\
\text { hepatites para, } \\
\text { pelo menos } 60 \% \\
\text { dos projetos da } \\
\text { OSC e de } \\
\text { governos. A } \\
\text { meta para } 2011, \\
\text { é de } 100 \% \text {. }\end{array}$ & $\begin{array}{l}\text { Descentralizar } \\
\text { recurso para } \\
\text { os projetos } \\
\text { selecionados } \\
\text { que tenha } \\
\text { como objeto } \\
\text { ações de } \\
\text { prevenção } \\
\text { voltadas à } \\
\text { população de } \\
\text { gays, HSH e } \\
\text { travestis em } \\
\text { conformidade } \\
\text { com o edital - } \\
\text { seleção de } \\
\text { projetos para } \\
\text { OSC }\end{array}$ & $\begin{array}{c}\text { Produzir } \\
\text { material } \\
\text { informativo } \\
\text { para reduc } \square \text { ão } \\
\text { do estigma } \\
\text { associado à } \\
\text { infecção pelo } \\
\text { HIV/aids entre } \\
\text { gays, HSH e } \\
\text { travestis. } \\
\text { Disponibilizar } \\
\text { o material em } \\
\text { locais de } \\
\text { circulação de } \\
\text { gays, outros } \\
\text { HSH e } \\
\text { travestis. e as } \\
\text { travestis } \\
\text { embora esteja } \\
\text { no imaginário } \\
\text { da maior parte } \\
\text { das pessoas é } \\
\text { pouco } \\
\text { explorado no } \\
\text { campo da } \\
\text { prevenção do } \\
\text { HIV/Aids. }\end{array}$ & $\begin{array}{c}\text { Distinguir } \\
\text { identificação x } \\
\text { nome social. }\end{array}$ \\
\hline $\begin{array}{l}\text { Capacitar e sensibilizar de } \\
\text { maneira continua os } \\
\text { profissionais dos serviços de } \\
\text { saúde no atendimento as } \\
\text { DST/HIV/Aids em temas } \\
\text { relacionados com a temática }\end{array}$ & $\begin{array}{l}\text { Verificar, junto } \\
\text { ao setor de } \\
\text { regulação de } \\
\text { consultas da } \\
\text { SES, a } \\
\text { possibilidade de }\end{array}$ & $\begin{array}{l}\text { Solicitar a } \\
\text { inserc } \square \text { ão na } \\
\text { pauta dentro } \\
\text { do Conselho } \\
\text { Estadual e nos } \\
\text { Conselho }\end{array}$ & $\begin{array}{c}\text { Realizar } \\
\text { campanha de } \\
\text { comunicac } \square \tilde{a} \\
\text { o com a } \\
\text { temática da } \\
\text { diversidade }\end{array}$ & $\begin{array}{c}\text { Oferecer servic } \square \text { os } \\
\text { de mamografia } \\
\text { para travestis e } \\
\text { transexuais; }\end{array}$ \\
\hline
\end{tabular}




\begin{tabular}{|c|c|c|c|c|}
\hline $\begin{array}{l}\text { da diversidade sexual, } \\
\text { direitos humanos, entre } \\
\text { outros. }\end{array}$ & $\begin{array}{l}\text { organizar o } \\
\text { sistema de } \\
\text { refere } \square \text { ncia e } \\
\text { contrarrefere } \square \text { n } \\
\text { cia para } \\
\text { infectologistas } \\
\text { via sistema de } \\
\text { regulac } \square \text { ão. }\end{array}$ & $\begin{array}{l}\text { Municipais } \\
\text { dos } \\
\text { municípios } \\
\text { que possuem } \\
\text { PAM de } \\
\text { assento para } \\
\text { representac } \square \text { ã } \\
\text { o do Mov. } \\
\text { LGBT }\end{array}$ & $\begin{array}{l}\text { sexual. (BA) } \\
\text { Como dito } \\
\text { anteriormente } \\
\text { a diversidade } \\
\text { sexual é um } \\
\text { dos } \\
\text { marcadores } \\
\text { que compõe o } \\
\text { universo das } \\
\text { travestis, } \\
\text { entretanto } \\
\text { seria } \\
\text { importante, no } \\
\text { caso das } \\
\text { travestis, que } \\
\text { as campanhas } \\
\text { também } \\
\text { problematizass } \\
\text { em o fato de } \\
\text { que as } \\
\text { travestis são } \\
\text { tão } \\
\text { estigmatizadas } \\
\text { pela } \\
\text { "diversidade } \\
\text { sexual" quanto } \\
\text { pela } \\
\text { identidade de } \\
\text { gênero e } \\
\text { "construção" } \\
\text { de seus } \\
\text { corpos, } \\
\text { trejeitos e } \\
\text { performances. }\end{array}$ & \\
\hline $\begin{array}{c}\text { Realizar um evento } \\
\text { (seminários/palestras/congre } \\
\text { ssos/ oficinas) visando à } \\
\text { sensibilizac } \square \text { ão e } \\
\text { humanizac } \square \text { ão, junto aos } \\
\text { Profissionais de Saúde do } \\
\text { SUS, sobre as } \\
\text { vulnerabilidades dessa } \\
\text { populac } \square \text { ão; }\end{array}$ & $\begin{array}{c}\text { Pautar a } \\
\text { temática LGBT } \\
\text { (Lésbicas, Gay, } \\
\text { bissexuais, } \\
\text { Travestis e } \\
\text { Transexuais) } \\
\text { nos Conselhos } \\
\text { de Saúde } \\
\text { Estadual e } \\
\text { municipais para } \\
\text { inclusão da } \\
\text { temática LGBT } \\
\text { nos Planos } \\
\text { Estadual e } \\
\text { municipais de } \\
\text { Saúde }\end{array}$ & $\begin{array}{l}\text { Fortaleciment } \\
\text { o do Fórum } \\
\text { Estadual } \\
\text { LGBT. }\end{array}$ & $\begin{array}{c}\text { formulac } \square \text { ão } \\
\text { de materiais } \\
\text { educativos } \\
\text { sobre } \\
\text { prevenc } \square \text { ão } \\
\text { de DST, } \\
\text { hepatites e } \\
\text { HIV/aids, } \\
\text { incluindo } \\
\text { mensagens } \\
\text { sobre: } \\
\text { (1) riscos do } \\
\text { sexo anal e } \\
\text { oral sem } \\
\text { protec } \square \text { ão, } \\
\text { (2) } \\
\text { relaxamento } \\
\text { das ac } \square \text { ões de } \\
\text { prevenc } \square \text { ão } \\
\text { no contexto da } \\
\text { disponibilidad } \\
\text { e do } \\
\text { tratamento } \\
\text { antirretroviral } \\
\text { e no contexto } \\
\text { de }\end{array}$ & $\begin{array}{c}\text { Oferecer } \\
\text { atendimento } \\
\text { visando à } \\
\text { reduc } \square \text { ão de danos } \\
\text { do uso do } \\
\text { hormo } \square \text { nio e de } \\
\text { silicone industrial } \\
\text { para travestis; }\end{array}$ \\
\hline
\end{tabular}




\begin{tabular}{|c|c|c|c|c|}
\hline & & & $\begin{array}{l}\text { relacionament } \\
\text { os estáveis, } \\
\text { (3) uso de } \\
\text { álcool ou } \\
\text { outras drogas } \\
\text { antes das } \\
\text { relac } \square \text { ões } \\
\text { sexuais e } \\
\text { (4) a falsa } \\
\text { noc } \square \text { ão de } \\
\text { "imunidade"d } \\
\text { evido aos } \\
\text { seguidos } \\
\text { resultados de } \\
\text { exames } \\
\text { negativos para } \\
\text { o HIV } \\
\text { conhecimento } \\
\text { sobre o nivel } \\
\text { de risco } \\
\text { relacionado às } \\
\text { diferentes } \\
\text { exposições } \\
\text { sexuais ativo } \\
\text { sem } \\
\text { preservativo) } \\
\text { são } \\
\text { conhecidas } \\
\text { entre as } \\
\text { travestis. }\end{array}$ & \\
\hline $\begin{array}{c}\text { Realizar seminários e } \\
\text { oficinas visando à } \\
\text { sensibilizac } \square \text { ão e } \\
\text { humanizac } \square \text { ão dos } \\
\text { Profissionais de Saúde do } \\
\text { SUS sobre as } \\
\text { vulnerabilidades dessa } \\
\text { populac } \square \text { ão; }\end{array}$ & $\begin{array}{c}\text { Pautar, junto aos } \\
\text { colegiados } \\
\text { gestores (CES - } \\
\text { Cons. Est. de } \\
\text { Saúde, } \\
\text { Tripartite, } \\
\text { COSEMS), as } \\
\text { temáticas que } \\
\text { envolvem a } \\
\text { populac } \square \text { ão } \\
\text { LGBT. }\end{array}$ & $\begin{array}{c}\text { Estimular, } \\
\text { mediante os } \\
\text { editais de } \\
\text { projetos para } \\
\text { OSC, o } \\
\text { desenvolvime } \\
\text { nto de ac } \square \text { ões } \\
\text { de } \\
\text { prevenc } \square \text { ão } \\
\text { voltadas à } \\
\text { populac } \square \text { ão } \\
\text { adulta e } \\
\text { adolescente } \\
\text { privada de } \\
\text { liberdade, com } \\
\text { recorte em } \\
\text { sexualidade, } \\
\text { orientac } \square \text { ão } \\
\text { sexual e } \\
\text { identidade de } \\
\text { ge } \square \text { nero. }\end{array}$ & $\begin{array}{c}\text { Elaborar e } \\
\text { confeccionar } \\
\text { materiais } \\
\text { educativos, } \\
\text { voltados aos } \\
\text { profissionais } \\
\text { de saúde, para } \\
\text { o atendimento } \\
\text { humanizado } \\
\text { ao público de } \\
\text { gays, HSH e } \\
\text { travestis; }\end{array}$ & $\begin{array}{c}\text { Implantar a } \\
\text { regulamentac } \square \text { ão } \\
\text { que permite a } \\
\text { utilizac } \square \text { ão do } \\
\text { nome social; (RJ) }\end{array}$ \\
\hline $\begin{array}{l}\text { Capacitar as OSC para a } \\
\text { produc } \square \text { ão de } \\
\text { conhecimentos básicos em } \\
\text { DST, hepatites e HIV/aids, } \\
\text { com a finalidade de formar } \\
\text { multiplicadores de práticas } \\
\text { corretas de prevenc } \square \text { ão e } \\
\text { reduc } \square \text { ão de estigma, } \\
\text { dentro dos moldes da }\end{array}$ & $\begin{array}{l}\text { Realizar } \\
\text { reunioes com } \\
\text { Conselhos de } \\
\text { Saude, } \\
\text { Conselhos de } \\
\text { Gestores de } \\
\text { Saude e } \\
\text { Gerentes de } \\
\text { Unidades de }\end{array}$ & $\begin{array}{c}\text { Garantia de } \\
\text { sustentabilidad } \\
\text { e do } \\
\text { movimento. } \\
\text { (ES) De que } \\
\text { sustentabilidad } \\
\text { e estamos } \\
\text { falando? De } \\
\text { sustentabilidad }\end{array}$ & $\begin{array}{l}\text { Elaborar e } \\
\text { confeccionar } \\
\text { materiais } \\
\text { educativos } \\
\text { (com } \\
\text { linguagem } \\
\text { específica) } \\
\text { voltados à } \\
\text { populac } \square \text { ão }\end{array}$ & $\begin{array}{l}\text { Realizar uma } \\
\text { reunião anual } \\
\text { ampliada com foco } \\
\text { no diálogo e } \\
\text { articulac } \square \text { ão entre } \\
\text { representantes do } \\
\text { movimento de } \\
\text { travestis, gestores, } \\
\text { gerentes e }\end{array}$ \\
\hline
\end{tabular}




\begin{tabular}{|c|c|c|c|c|}
\hline $\begin{array}{c}\text { capacitac } \square \text { ão para } \\
\text { aconselhamento pré- teste. }\end{array}$ & $\begin{array}{l}\text { Saude com a } \\
\text { participacao das } \\
\text { OSC sobre a } \\
\text { importancia da } \\
\text { criac } \square \text { ão de } \\
\text { horários } \\
\text { alternativos de } \\
\text { funcionamento } \\
\text { para atender ao } \\
\text { segmento de } \\
\text { gays, HSH e } \\
\text { travestis. }\end{array}$ & $\begin{array}{l}\text { e financeira, } \\
\text { politica? Seria } \\
\text { tarefa do } \\
\text { governo } \\
\text { garantir a } \\
\text { sustentabilidad } \\
\text { e politica e } \\
\text { financeira das } \\
\text { ONG`s? }\end{array}$ & $\begin{array}{l}\text { de gays, HSH } \\
\text { e travestis, } \\
\text { com foco na } \\
\text { prevenc } \square \text { ão às } \\
\text { DST/HIV/aids } \\
;\end{array}$ & $\begin{array}{c}\text { profissionais do } \\
\text { servic } \square \text { o de saúde, } \\
\text { trazendo assuntos } \\
\text { como inclusão das } \\
\text { especificidades de } \\
\text { travestis - p. ex., } \\
\text { acesso a próteses } \\
\text { de silicone, } \\
\text { proctologistas, } \\
\text { hormonoterapia via } \\
\text { SUS e } \\
\text { informac } \square \text { ões } \\
\text { sobre os riscos de } \\
\text { uso de silicone } \\
\text { industrial } \\
\text { (criac } \square \text { ão portaria). } \\
\text { (RO) }\end{array}$ \\
\hline $\begin{array}{c}\text { Realizar oficina para } \\
\text { sensibilizac } \square \text { ão e } \\
\text { capacitac } \square \text { ão de } \\
\text { profissionais e estudantes } \\
\text { dos meios de } \\
\text { comunicac } \square \text { ão em temas } \\
\text { referentes à vulnerabilidade } \\
\text { de gays, outros HSH e } \\
\text { travestis às DST, hepatites e } \\
\text { HIV/aids }\end{array}$ & $\begin{array}{c}\text { Nos } \\
\text { treinamentos da } \\
\text { SES, incluir a } \\
\text { temática de } \\
\text { temas } \\
\text { relacionados à } \\
\text { gays, HSH e } \\
\text { travestis } \\
\text { (ge } \square \text { nero, } \\
\text { orientac } \square \text { ão } \\
\text { sexual e } \\
\text { identidade de } \\
\text { ge } \square \text { nero). }\end{array}$ & $\begin{array}{c}\text { Construir } \\
\text { planejamentos } \\
\text { para a revisão } \\
\text { e } \\
\text { reelaborac } \square \text { ão } \\
\text { das atuac } \square \text { ões } \\
\text { do movimento } \\
\text { LGBT } \\
\text { Confusão } \\
\text { entre gestão e } \\
\text { movimento } \\
\text { social. Aqui é } \\
\text { possível } \\
\text { perceber que } \\
\text { não fica claro } \\
\text { para quem } \\
\text { constrói a } \\
\text { agenda do } \\
\text { plano o que é } \\
\text { tarefa da } \\
\text { gestão. }\end{array}$ & $\begin{array}{l}\text { Desenvolver } \\
\text { estratégia de } \\
\text { comunicac } \square \text { ã } \\
\text { o focadas na } \\
\text { prevenc } \square \text { ão às } \\
\text { DST/aids e } \\
\text { hepatites para } \\
\text { gays, outros } \\
\text { HSH e } \\
\text { travestis, além } \\
\text { do combate à } \\
\text { homofobia e a } \\
\text { transfobia. }\end{array}$ & $\begin{array}{c}\text { Garantia da } \\
\text { portaria da inclusão } \\
\text { do nome social das } \\
\text { travestis nas fichas } \\
\text { do SUS. (RO) }\end{array}$ \\
\hline $\begin{array}{c}\text { Realizar ac } \square \text { ões de } \\
\text { sensibilizac } \square \text { ão e } \\
\text { capacitac } \square \text { ão para } \\
\text { profissionais da área de } \\
\text { segurança publica acerca } \\
\text { dos temas LGBT. }\end{array}$ & $\begin{array}{c}\text { Identificar e } \\
\text { criar parcerias } \\
\text { dentro das redes } \\
\text { estadual e } \\
\text { municipais para } \\
\text { execução de } \\
\text { ac } \square \text { ões } \\
\text { específica para } \\
\text { travestis; }\end{array}$ & $\begin{array}{l}\text { Realizar três } \\
\text { capacitações } \\
\text { regionais, até } \\
2010, \text { para } \\
\text { formação de } \\
\text { lideranças do } \\
\text { segmento para } \\
\text { o exercício do } \\
\text { controle social } \\
\text { no Estado. }\end{array}$ & $\begin{array}{l}\text { Produc } \square \text { ão, } \\
\text { veiculação e } \\
\text { qualificação } \\
\text { de campanhas } \\
\text { municipais } \\
\text { e/ou regionais } \\
\text { dirigidas à } \\
\text { populac } \square \text { ão } \\
\text { em geral } \\
\text { (MT). Realizar } \\
\text { campanhas } \\
\text { dirigidas à } \\
\text { população em } \\
\text { geral que } \\
\text { abordem às } \\
\text { temáticas } \\
\text { LGBT tem se } \\
\text { mostrado uma } \\
\text { tarefa difícil } \\
\text { diante das } \\
\text { bancadas } \\
\text { conservadoras, }\end{array}$ & $\begin{array}{c}\text { Realizar reunião } \\
\text { com a Diretoria de } \\
\text { Política de Saúde - } \\
\text { Gere } \square \text { ncia de } \\
\text { Políticas de } \\
\text { Regulac } \square \text { ão para } \\
\text { discutir a inclusão } \\
\text { do nome social e a } \\
\text { internac } \square \text { ão das } \\
\text { travestis em leitos } \\
\text { femininos, ou para } \\
\text { que tenham } \\
\text { autonomia de } \\
\text { escolha. }\end{array}$ \\
\hline
\end{tabular}




\begin{tabular}{|c|c|c|c|c|}
\hline & & & $\begin{array}{l}\text { aja visto o } \\
\text { veto para a } \\
\text { difusão da } \\
\text { última } \\
\text { campanha } \\
\text { voltado ao } \\
\text { público de } \\
\text { jovens gays. } \\
\text { Embora a } \\
\text { estratégia seja } \\
\text { bastante } \\
\text { importante é } \\
\text { necessário } \\
\text { estabelecer um } \\
\text { planejamento } \\
\text { consistente } \\
\text { para que tais } \\
\text { campanhas } \\
\text { sejam } \\
\text { difundidas } \\
\text { pelo governo e } \\
\text { pela sociedade } \\
\text { civil. }\end{array}$ & \\
\hline $\begin{array}{c}\text { Discutir especificamente } \\
\text { temas referentes às } \\
\text { vulnerabilidades de gays, } \\
\text { HSH e travestis e atenc } \square \text { ão } \\
\text { a casais do mesmo sexo, } \\
\text { incluindo sorodiscordantes, } \\
\text { nas capacitac } \square \text { ões } \\
\text { realizadas pela Gere } \square \text { ncia } \\
\text { de DST/Aids para } \\
\text { profissionais da atenc } \square \text { ão } \\
\text { básica. }\end{array}$ & $\begin{array}{c}\text { Integrar as } \\
\text { ac } \square \text { ões da } \\
\mathrm{Ca} \square \text { mara } \\
\text { Técnica de } \\
\text { Saúde LGBT. }\end{array}$ & $\begin{array}{c}\text { Fomentar } \\
\text { participac } \square \text { ão } \\
\text { política do } \\
\text { movimento } \\
\text { nos espac } \square \text { os } \\
\text { de } \\
\text { articulac } \square \text { ão e } \\
\text { decisão sobre } \\
\text { prevenc } \square \text { ão e } \\
\text { direitos de } \\
\text { LGBT }\end{array}$ & $\begin{array}{c}\text { Produc } \square \text { ão, } \\
\text { veiculac } \square \text { ão e } \\
\text { qualificac } \square \text { ão } \\
\text { de campanhas } \\
\text { municipais } \\
\text { e/ou regionais } \\
\text { dirigidas aos } \\
\text { gestores, } \\
\text { gerentes e } \\
\text { profissionais } \\
\text { de saúde, } \\
\text { inserindo } \\
\text { mensagens em } \\
\text { contas de } \\
\text { água, luz, } \\
\text { telefone, etc. }\end{array}$ & $\begin{array}{c}\text { Garantia da } \\
\text { resoluc } \square \text { ão que } \\
\text { ampara a inclusão } \\
\text { do nome social das } \\
\text { travestis (Portaria } \\
\text { 1820-GM), bem } \\
\text { como confeccionar } \\
\text { cartaz para os } \\
\text { centros de saúde } \\
\text { informando }\end{array}$ \\
\hline $\begin{array}{c}\text { Realizar oficinas de } \\
\text { sensibilizac } \square \text { ão com } \\
\text { profissionais dos centros de } \\
\text { refere } \square \text { ncia em HIV/aids, } \\
\text { para o correto acolhimento } \\
\text { de gays, outros HSH e } \\
\text { travestis }\end{array}$ & $\begin{array}{l}\text { Incluir quesitos } \\
\text { sobre a } \\
\text { incorporac } \square \text { ão } \\
\text { de práticas de } \\
\text { respeito à } \\
\text { diversidade } \\
\text { LGBT em } \\
\text { processo de } \\
\text { monitoramento } \\
\text { da qualidade } \\
\text { dos servic } \square \text { os. }\end{array}$ & $\begin{array}{l}\text { Realizar um } \\
\text { encontro entre } \\
\text { representantes } \\
\text { do movimento } \\
\text { LGBT e a } \\
\text { FINDES }\end{array}$ & $\begin{array}{c}\text { Realizac } \square \text { ão } \\
\text { de } \\
\text { formac } \square \text { ões e } \\
\text { produc } \square \text { ão de } \\
\text { material de } \\
\text { refere } \square \text { ncia } \\
\text { para a } \\
\text { organizac } \square \text { ão } \\
\text { dos servic } \square \text { os } \\
\text { de saúde e a } \\
\text { formac } \square \text { ão de } \\
\text { seus } \\
\text { profissionais } \\
\text { para acolher e } \\
\text { não } \\
\text { discriminar } \\
\text { gays, HSH e } \\
\text { travestis (MT). } \\
\text { O acolhimento } \\
\text { adequado a } \\
\text { diferentes }\end{array}$ & $\begin{array}{c}\text { Realizac } \square \text { ão de } 02 \\
\text { reuniões anuais } \\
\text { ampliadas com } \\
\text { foco no } \\
\text { dialogo e } \\
\text { articulac } \square \text { ão entre } \\
\text { representantes do } \\
\text { movimento social, } \\
\text { gestores, gerentes e } \\
\text { profissionais do } \\
\text { servic } \square \text { o de saúde, } \\
\text { trazendo assuntos } \\
\text { como inclusão das } \\
\text { especificidades das } \\
\text { travestis, acesso } \\
\text { aos proctologistas, } \\
\text { hormonioterapia } \\
\text { via SUS e } \\
\text { informac } \square \text { ões } \\
\text { sobre os riscos de } \\
\text { uso do silicone }\end{array}$ \\
\hline
\end{tabular}




\begin{tabular}{|c|c|c|c|c|}
\hline & & & $\begin{array}{l}\text { populações } \\
\text { estigmatizadas } \\
\text { parece uma } \\
\text { estratégia } \\
\text { interessante, } \\
\text { entretanto, } \\
\text { deve envolver } \\
\text { a todas as } \\
\text { pessoas que } \\
\text { compoe o } \\
\text { universo de } \\
\text { profissioanis } \\
\text { dos centros de } \\
\text { saúde, ou o } \\
\text { risco de que a } \\
\text { discriminação } \\
\text { ocorra é } \\
\text { bastante alto. }\end{array}$ & industrial. \\
\hline $\begin{array}{c}\text { Manter e/ou implementar as } \\
\text { capacitac } \square \text { ões em: } \\
\text { (1)Aconselhamento em } \\
\text { DST, hepatites e HIV/aids; } \\
\text { (2)Abordagem } \\
\text { Sindro } \square \text { mica de DST; e } \\
\text { (3)Testagem Rápida } \\
\text { Diagnóstica para o HIV, } \\
\text { temas relacionados ao } \\
\text { acolhimento adequado de } \\
\text { homens gays, outros HSH e } \\
\text { travestis em servic } \square \text { os de } \\
\text { saúde da SES, incluindo as } \\
\text { especificidades de travestis } \\
\text { quanto ao uso de silicone e } \\
\text { hormonoterapia .estigma do } \\
\text { não pertencimento a } \\
\text { categoria humana. }\end{array}$ & $\begin{array}{c}\text { Divulgar o } \\
\text { protocolo de } \\
\text { atendimento } \\
\text { para propiciar a } \\
\text { incorporac } \square \text { ão, } \\
\text { nos servic } \square \text { os } \\
\text { de saúde, de } \\
\text { práticas } \\
\text { adequadas na } \\
\text { abordagem e } \\
\text { aconselhamento } \\
\text { para gays e } \\
\text { outros HSH e } \\
\text { travestis, na } \\
\text { perspectiva da } \\
\text { Prevenc } \square \text { ão } \\
\text { Posithiva; }\end{array}$ & $\begin{array}{c}\text { Garantir } \\
\text { recursos e } \\
\text { apoio técnico } \\
\text { às OSC que } \\
\text { manifestem } \\
\text { interesse em } \\
\text { exercer } \\
\text { parceria com a } \\
\text { política de } \\
\text { saúde de } \\
\text { DST/aids para } \\
\text { o } \\
\text { enfrentamento } \\
\text { das DST/aids } \\
\text { entre gays, } \\
\text { outros HSH e } \\
\text { travestis, em } \\
\text { conformidade } \\
\text { com o } \\
\text { regulamento } \\
\text { do pacto pela } \\
\text { saúde (MA); } \\
\text { Apoio por } \\
\text { meio de } \\
\text { recursos e } \\
\text { apoio técnico } \\
\text { para } \\
\text { enfrentamento } \\
\text { das } \\
\text { DST/HIV/Aid } \\
\text { s. }\end{array}$ & $\begin{array}{c}\text { Realizar } \\
\text { ac } \square \text { ões } \\
\text { preventivas / } \\
\text { nas paradas de } \\
\text { diversidade. }\end{array}$ & $\begin{array}{l}\text { Promoc } \square \text { ão da } \\
\text { discussão e da } \\
\text { inclusão das } \\
\text { especificidades de } \\
\text { saúde das travestis } \\
\text { (por exemplo, } \\
\text { acesso a próteses } \\
\text { de silicone, } \\
\text { hormonioterapia } \\
\text { via SUS e riscos de } \\
\text { uso de silicone } \\
\text { industrial) e nas } \\
\text { ac } \square \text { ões de } \\
\text { assiste } \square \text { ncia e } \\
\text { tratamento de } \\
\text { travestis que vivem } \\
\text { com HIV/AIDS. }\end{array}$ \\
\hline $\begin{array}{c}\text { Capacitar } 50 \text { gestorese } 150 \\
\text { profissionais da saúde, } \\
\text { assiste } \square \text { ncia social, } \\
\text { educac } \square \text { ão para } \\
\text { compreensão dos temas } \\
\text { pertinentes ao } \\
\text { enfrentamento da epidemia } \\
\text { da aids em sua } \\
\text { complexidade (na } \\
\text { prevenc } \square \text { ão, na } \\
\text { promoc } \square \text { ão, no controle }\end{array}$ & $\begin{array}{c}\text { Desenvolver } \\
\text { ac } \square \text { ões voltadas } \\
\text { para a } \\
\text { ampliac } \square \text { ão da } \\
\text { responsabilidad } \\
\text { e social de } \\
\text { empresas no } \\
\text { enfrentamento } \\
\text { das DST, } \\
\text { hepatites e } \\
\text { HIV/aids junto }\end{array}$ & $\begin{array}{c}\text { Apoio a } \\
\text { projetos de } \\
\text { governo e das } \\
\text { OSC para a } \\
\text { realizac } \square \text { ão } \\
\text { das ac } \square \text { ões de } \\
\text { reduc } \square \text { ão do } \\
\text { estigma (MT) }\end{array}$ & $\begin{array}{l}\text { Criac } \square \text { ão de } \\
\text { materiais } \\
\text { educativos } \\
\text { considerando } \\
\text { o universo e a } \\
\text { visibilidade } \\
\text { positiva dos } \\
\text { gays, HSH e } \\
\text { travestis junto } \\
\text { às insta } \square \text { ncias } \\
\text { municipais, }\end{array}$ & $\begin{array}{l}\text { Garantir recursos } \\
\text { para dar } \\
\text { visibilidade } \\
\text { positiva às travestis } \\
\text { (a exemplo da } \\
\text { campanha nacional } \\
\text { "Travesti e } \\
\text { Respeito", com } \\
\text { material disponível } \\
\text { no Departamento } \\
\text { de DST, Aids e }\end{array}$ \\
\hline
\end{tabular}




\begin{tabular}{|c|c|c|c|c|}
\hline $\begin{array}{l}\text { social) e os papéis exercidos } \\
\text { pelos gestores e } \\
\text { profissionais na tarefa do } \\
\text { enfrentamento da AIDS } \\
\text { garantindo prioridade para } \\
\text { gays, HSH e travestis. }\end{array}$ & $\begin{array}{c}\text { aos gays, outros } \\
\text { HSH e travestis } \\
\text { (DF) } \\
\text { Envolvimento } \\
\text { de empresas no } \\
\text { enfrentamento } \\
\text { ao HIV/Aids. } \\
\text { Não é possivel } \\
\text { saber como isto } \\
\text { será feito. }\end{array}$ & & $\begin{array}{c}\text { aos servic } \square \text { os } \\
\text { de saúde e à } \\
\text { populac } \square \text { ão } \\
\text { em geral }\end{array}$ & Hepatites Virais). \\
\hline $\begin{array}{l}\text { Realizar } 01 \text { formac } \square \text { ão } \\
\text { anual com policiais civis, } \\
\text { militares e guardas civis } \\
\text { municipais acerca das } \\
\text { temáticas LGBT e direitos } \\
\text { humanos; }\end{array}$ & $\begin{array}{c}\text { Incluir quesitos } \\
\text { sobre a } \\
\text { incorporac } \square \text { ão } \\
\text { de práticas de } \\
\text { respeito à } \\
\text { diversidade } \\
\text { LGBT em } \\
\text { processo de } \\
\text { monitoramento } \\
\text { da qualidade } \\
\text { dos servic } \square \text { os. }\end{array}$ & $\begin{array}{c}\text { Estabelecer, } \\
\text { junto aos } \\
\text { movimentos } \\
\text { da sociedade } \\
\text { civil } \\
\text { representativo } \\
\text { s da } \\
\text { populac } \square \text { ão } \\
\text { de gays, } \\
\text { outros HSH e } \\
\text { travestis, as } \\
\text { responsabilida } \\
\text { des dessa } \\
\text { distribuic } \square \text { ão } \\
\text { (refere-se aos } \\
\text { insumos de } \\
\text { prevençāo a } \\
\text { serem } \\
\text { distribuidos } \\
\text { em locais de } \\
\text { socialização) } \\
\text { bem como } \\
\text { desse } \\
\text { monitorament } \\
\text { o. }\end{array}$ & $\begin{array}{c}\text { Criac } \square \text { ão de } \\
\text { material } \\
\text { educativo para } \\
\text { divulgac } \square \text { ão } \\
\text { dos Direitos } \\
\text { Humanos e } \\
\text { sexuais dessa } \\
\text { populac } \square \text { ão }\end{array}$ & $\begin{array}{c}\text { Ampliar a } \\
\text { Campanha do } \\
\text { Fique Sabendo à } \\
\text { populac } \square \text { ão de } \\
\text { travestis, em } \\
\text { parceria com os } \\
\text { movimentos } \\
\text { sociais. }\end{array}$ \\
\hline $\begin{array}{c}\text { Realizar } 01 \text { seminário anual } \\
\text { sobre a temática educac } \square \text { ão, } \\
\text { questão LGBT e } \\
\text { heterossexismo para } \\
\text { secretarias municipais e } \\
\text { estadual de educac } \square \text { ão e } \\
\text { professore da rede; }\end{array}$ & $\begin{array}{c}\text { Realizar ac } \square \text { ões } \\
\text { nacionais nas } \\
\text { áreas de saúde e } \\
\text { educac } \square \text { ão que } \\
\text { contribuam para } \\
\text { a reduc } \square \text { ão das } \\
\text { vulnerabilidades } \\
\text { às DST/AIDS } \\
\text { associadas à } \\
\text { homofobia / } \\
\text { transfobia } \\
\text { institucional. }\end{array}$ & $\begin{array}{c}\text { Realizar } \\
\text { mapeamento } \\
\text { das } \\
\text { experie } \square \text { ncias } \\
\text { exitosas de } \\
\text { ONG a serem } \\
\text { utilizadas } \\
\text { como } \\
\text { refere } \square \text { ncia e } \\
\text { potencializada } \\
\text { s no trabalho } \\
\text { junto à } \\
\text { populac } \square \text { ão } \\
\text { LGBT. } \\
\text { Incentivar e } \\
\text { conhecer as } \\
\text { experiencias } \\
\text { exitosas das } \\
\text { ONGs é } \\
\text { importante, } \\
\text { entretanto não } \\
\text { deve ser } \\
\text { confundido } \\
\text { com o que } \\
\text { deve ser feito }\end{array}$ & $\begin{array}{c}\text { Promover } \\
\text { campanhas de } \\
\text { prevenc } \square \text { ão } \\
\text { nos espac } \square \text { os } \\
\text { lúdicos da } \\
\text { populac } \square \text { ão } \\
\text { LGBT } \\
\text { (queimadas e } \\
\text { quadrilhas). }\end{array}$ & $\begin{array}{c}\text { Ampliar a } \\
\text { participac } \square \text { ão das } \\
\text { travestis na } \\
\text { realizac } \square \text { ão de } \\
\text { testagem voluntária } \\
\text { e aconselhamento } \\
\text { para diagnóstico do } \\
\text { HIV. (PB) }\end{array}$ \\
\hline
\end{tabular}




\begin{tabular}{|c|c|c|c|c|}
\hline & & $\begin{array}{c}\text { pela própria } \\
\text { gestão. A } \\
\text { exemplo da } \\
\text { proposta de } \\
\text { capacitar as } \\
\text { OSC para } \\
\text { produção de } \\
\text { informacoes } \\
\text { sobre } \\
\text { prevenção, ou } \\
\text { mesmo a } \\
\text { própria } \\
\text { "criação" de } \\
\text { ONG por parte } \\
\text { do } \\
\text { governoRealiz } \\
\text { ar } \\
\text { mapeamento } \\
\text { das } \\
\text { experie } \square \text { ncias } \\
\text { exitosas de } \\
\text { ONG a serem } \\
\text { utilizadas } \\
\text { como } \\
\text { refere } \square \text { ncia e } \\
\text { potencializada } \\
\text { s no trabalho } \\
\text { junto à } \\
\text { populac } \square \text { ão } \\
\text { LGBT. }\end{array}$ & & \\
\hline $\begin{array}{c}\text { Mapear, junto às } \\
\text { organizac } \square \text { ões da sociedade } \\
\text { civil, os indivíduos a serem } \\
\text { formados (referindo-se aos } \\
\text { cursos profissionalizantes } \\
\text { para gays e travestis). }\end{array}$ & $\begin{array}{c}\text { Realizar ac } \square \text { ões } \\
\text { Estadual/Munici } \\
\text { pais nas áreas de } \\
\text { saúde e } \\
\text { educac } \square \text { ão que } \\
\text { contribuam para } \\
\text { a reduc } \square \text { ão das } \\
\text { vulnerabilidades } \\
\text { às DST/AIDS } \\
\text { associadas à } \\
\text { homofobia/trans } \\
\text { fobia } \\
\text { institucional. }\end{array}$ & $\begin{array}{c}\text { Estimular a } \\
\text { participac } \square \text { ão } \\
\text { da sociedade } \\
\text { civil, } \\
\text { principalmente } \\
\text { de grupos e } \\
\text { ONG que } \\
\text { atuam junto às } \\
\text { travestis, no } \\
\text { Comite } \square \\
\text { Técnico da } \\
\text { Diversidade } \\
\text { Sexual da CE } \\
\text { Estadual DST } \\
\text { Aids/CRT e } \\
\text { em outros } \\
\text { Comite } \square \text { s de } \\
\text { prevenc } \square \text { ão. }\end{array}$ & $\begin{array}{c}\text { Promover } \\
\text { junto aos } \\
\text { meios de } \\
\text { comunicac } \square \text { ã } \\
\text { o de massa a } \\
\text { veiculac } \square \text { ão } \\
\text { de mensagens } \\
\text { qualificadas } \\
\text { de promoc } \square \text { ão } \\
\text { dos direitos de } \\
\text { cidadania dos } \\
\text { gays, Travestis } \\
\text { e outros HSH. }\end{array}$ & $\begin{array}{c}\text { Definir } \\
\text { notificac } \square \text { ão nos } \\
\text { servic } \square \text { os de } \\
\text { saúde, com } \\
\text { inclusão das } \\
\text { travestis na } \\
\text { categoria de } \\
\text { exposic } \square \text { ão do } \\
\text { HIV/Aids. }\end{array}$ \\
\hline $\begin{array}{c}\text { Realizar a qualificac } \square \text { ão de } \\
150 \text { profissionais que atuam } \\
\text { na área de } \\
\text { prevenc } \square \text { ão/assiste } \square \text { ncia a } \\
\text { DST/Aids e de cidadania da } \\
\text { populac } \square \text { ão de gays, } \\
\text { travestis e HSH para } \\
\text { ampliar a qualidade do } \\
\text { acolhimento, assiste } \square \text { ncia e } \\
\text { tratamento das } \\
\text { DST/HIV/aids e hepatites } \\
\text { para travestis. }\end{array}$ & $\begin{array}{l}\text { Realizar } \\
\text { reunioes com } \\
\text { Conselhos de } \\
\text { Saude, } \\
\text { Conselhos de } \\
\text { Gestores de } \\
\text { Saude e } \\
\text { Gerentes de } \\
\text { Unidades de } \\
\text { Saude com a } \\
\text { participacao das } \\
\text { OSC sobre a }\end{array}$ & $\begin{array}{l}\text { Articular com } \\
\text { os } \\
\text { movimentos } \\
\text { sociais a } \\
\text { discussão } \\
\text { sobre } \\
\text { temáticas } \\
\text { relacionadas à } \\
\text { populac } \square \text { ão } \\
\text { de gays, } \\
\text { outros HSH e } \\
\text { travestis para }\end{array}$ & $\begin{array}{l}\text { Desenvolver } \\
\text { pelo menos } \\
\text { uma } \\
\text { campanha } \\
\text { anual de } \\
\text { comunicac } \square \text { ã } \\
\text { o para } \\
\text { reduc } \square \text { ão da } \\
\text { vulnerabilidad } \\
\text { e, dar } \\
\text { visibilidade à } \\
\text { gravidade da }\end{array}$ & $\begin{array}{c}\text { Criac } \square \text { ão de } \\
\text { variáveis nas fichas } \\
\text { de notificação da } \\
\text { orientacao sexual e } \\
\text { identidade de } \\
\text { geneto }\end{array}$ \\
\hline
\end{tabular}




\begin{tabular}{|c|c|c|c|c|}
\hline & $\begin{array}{l}\text { importancia da } \\
\text { criac } \square \text { ão de } \\
\text { horários } \\
\text { alternativos de } \\
\text { funcionamento } \\
\text { para atender ao } \\
\text { segmento de } \\
\text { gays, HSH e } \\
\text { travestis. }\end{array}$ & $\begin{array}{l}\text { divulgac } \square \text { ão } \\
\text { do Plano nos } \\
\text { encontros } \\
\text { programados } \\
\text { pelo Estado e } \\
\text { municípios. }\end{array}$ & $\begin{array}{c}\text { epidemia entre } \\
\text { gays, travestis } \\
\text { e outros HSH } \\
\text { e estimular o } \\
\text { diagnóstico e } \\
\text { tratamento das } \\
\text { DST, hepatites } \\
\text { e AIDS. }\end{array}$ & \\
\hline $\begin{array}{c}\text { Realizar "Rodas de } \\
\text { Discussões" com as ONG e } \\
\text { com as Coordenac } \square \text { ões } \\
\text { Municipais de DST/Aids } \\
\text { visando elaborar a } \\
\text { programac } \square \text { ão da oficina de } \\
\text { sensibilizac } \square \text { ão para o } \\
\text { atendimento aos gays, HSH } \\
\text { e travestis nos servic } \square \text { os de } \\
\text { saúde. }\end{array}$ & $\begin{array}{c}\text { Divulgar o } \\
\text { protocolo de } \\
\text { atendimento } \\
\text { para propiciar a } \\
\text { incorporac } \square \text { ão, } \\
\text { nos servic } \square \text { os } \\
\text { de saúde, de } \\
\text { práticas } \\
\text { adequadas na } \\
\text { abordagem e } \\
\text { aconselhamento } \\
\text { para gays e } \\
\text { outros HSH e } \\
\text { travestis, na } \\
\text { perspectiva da } \\
\text { Prevenc } \square \text { ão } \\
\text { Posithiva; }\end{array}$ & $\begin{array}{c}\text { Realizar } \\
\text { mostra de } \\
\text { experie } \square \text { ncias } \\
\text { exitosas de } \\
\text { prevenc } \square \text { ão } \\
\text { realizada pela } \\
\text { OSC e } \\
\text { governos - } \\
\text { referente ao } \\
\text { objetivo: } \\
\text { "Implantar } \\
\text { mecanismos } \\
\text { para } \\
\text { identificac } \square \text { ão } \\
\text { e difusão de } \\
\text { experie } \square \text { ncias } \\
\text { e práticas } \\
\text { inovadoras e } \\
\text { bem-sucedidas } \\
\text { realizadas por } \\
\text { governos e } \\
\text { OSC e } \\
\text { voltadas para } \\
\text { o } \\
\text { enfrentamento } \\
\text { das } \\
\text { DST/AIDS } \\
\text { junto aos gays, } \\
\text { travestis e } \\
\text { outros HSH" }\end{array}$ & $\begin{array}{c}\text { Realizar } \\
\text { ac } \square \text { ões de } \\
\text { comunicac } \square \text { ã } \\
\text { o e } \\
\text { informac } \square \text { ão } \\
\text { específicas } \\
\text { que } \\
\text { contribuam } \\
\text { para a } \\
\text { reduc } \square \text { ão de } \\
\text { contextos de } \\
\text { vulnerabilidad } \\
\text { e social, } \\
\text { institucional e } \\
\text { individual } \\
\text { associados às } \\
\text { DST/HIV. }\end{array}$ & $\begin{array}{c}\text { Inclusão da } \\
\text { categoria "travesti" } \\
\text { nos sistemas de } \\
\text { informac } \square \text { ão e de } \\
\text { monitoramento dos } \\
\text { Centros de } \\
\text { Testagem e } \\
\text { Aconselhamento. }\end{array}$ \\
\hline $\begin{array}{l}\text { Realizar capacitac } \square \text { ão para } \\
\text { profissionais que atuam com } \\
\text { gays, HSH e travestis, } \\
\text { objetivando formar } \\
\text { multiplicadores para o } \\
\text { acolhimento nos servic } \square \text { os } \\
\text { públicos (Coordenac } \square \text { ões } \\
\text { Municipais de DST/Aids, } \\
\text { ONG, Regionais de Saúde, } \\
\text { Sec. Estadual de } \\
\text { Educac } \square \text { ão, SEMIRA, } \\
\text { Sistema Penitenciário } \\
\text { Prisional);. }\end{array}$ & $\begin{array}{c}\text { Mapear, } \\
\text { consolidar e } \\
\text { unificar os } \\
\text { dados sobre as } \\
\text { organizac } \square \text { ões } \\
\text { que } \\
\text { desenvolvem } \\
\text { trabalhos com } \\
\text { HSH, gays e } \\
\text { travestis Alguns } \\
\text { Estados } \\
\text { demonstram não } \\
\text { conhecer as } \\
\text { organizações } \\
\text { sociais que } \\
\text { atuam com } \\
\text { travestis e se } \\
\text { propõe a mapea- } \\
\text { las como uma } \\
\text { das atividades } \\
\text { de prevenção. }\end{array}$ & $\begin{array}{c}\text { Apoiar as } \\
\text { Organizac } \square \text { õe } \\
\text { s da Sociedade } \\
\text { Civil e o } \\
\text { movimento } \\
\text { social para a } \\
\text { realizac } \square \text { ão } \\
\text { de ac } \square \text { ões de } \\
\text { promoc } \square \text { ão } \\
\text { em saúde e de } \\
\text { visibilidade } \\
\text { dos direitos de } \\
\text { cidadania dos } \\
\text { gays, travestis } \\
\text { e outros HSH, } \\
\text { nas datas } \\
\text { comemorativa } \\
\text { s do seu } \\
\text { calendário: } \\
\text { DIA } \\
\text { INTERNACI }\end{array}$ & $\begin{array}{c}\text { Produc } \square \text { ão e } \\
\text { divulgac } \square \text { ão } \\
\text { de um material } \\
\text { informativo } \\
\text { referencial } \\
\text { sobre } \\
\text { especificidade } \\
\text { s e contextos } \\
\text { de } \\
\text { vulnerabilidad } \\
\text { e associados à } \\
\text { epidemia do } \\
\text { HIV/AIDS e } \\
\text { agravos à } \\
\text { saúde das } \\
\text { travestis, gays, } \\
\text { HSH } \\
\text { direcionados a } \\
\text { prostituição }\end{array}$ & $\begin{array}{c}\text { Realizar } \\
\text { diagnóstico } \\
\text { situacional (perfil } \\
\text { sociocultural, } \\
\text { comportamental e } \\
\text { epidemiológico) } \\
\text { associado às } \\
\text { DST/HIV/aids das } \\
\text { travestis no estado. }\end{array}$ \\
\hline
\end{tabular}




\begin{tabular}{|c|c|c|c|c|}
\hline & & $\begin{array}{l}\text { ONAL DO } \\
\text { ORGULHO } \\
\text { LGBT (28 de } \\
\text { junho). e b) } \\
\text { DIA DE } \\
\text { VISIBILIDA } \\
\text { DE DAS } \\
\text { TRAVESTIS } \\
\text { (29 de } \\
\text { janeiro). } \\
\text { c) DIA } \\
\text { ENFRENTA } \\
\text { MENTO À } \\
\text { HOMOFOBI } \\
\text { A (17 de } \\
\text { maio). }\end{array}$ & & \\
\hline $\begin{array}{c}\text { Realizar capacitac } \square \text { ão para } \\
\text { profissionais dos CTA sobre } \\
\text { diagnóstico de hepatites B e } \\
\text { C, com enfoque no } \\
\text { atendimento humanizado à } \\
\text { populac } \square \text { ão de gays, HSH e } \\
\text { travestis. }\end{array}$ & $\begin{array}{l}\text { Rever junto aos } \\
\text { CTA/SAE o } \\
\text { horários de } \\
\text { atendimento } \\
\text { para facilitar o } \\
\text { acesso das } \\
\text { travestis ao } \\
\text { diagnóstico das } \\
\text { DST/aids. }\end{array}$ & $\begin{array}{l}\text { Apoiar, junto } \\
\text { com a esfera } \\
\text { federal e o } \\
\text { municípios de } \\
\text { Natal, a } \\
\text { realizac } \square \text { ão } \\
\text { do VIII } \\
\text { Encontro } \\
\text { Regional } \\
\text { Nordeste de } \\
\text { Travestis e } \\
\text { Transexuais. }\end{array}$ & $\begin{array}{l}\text { Realizac } \square \text { ão } \\
\text { de campanhas } \\
\text { com imagem } \\
\text { que impactem } \\
\text { no público de } \\
\text { HSH, gays e } \\
\text { travestis. }\end{array}$ & $\begin{array}{c}\text { Realizar } \\
\text { levantamento nos } \\
\text { prontuários do } \\
\text { CRT (CTA, } \\
\text { Ambulatório de } \\
\text { DST e Ambulatório } \\
\text { de HIV/Aids) para } \\
\text { identificar o } \\
\text { numero de travestis } \\
\text { usuárias e o } \\
\text { numero de travestis } \\
\text { HIV+ em } \\
\text { acompanhamento } \\
\text { no CRT/DST-aids. }\end{array}$ \\
\hline $\begin{array}{l}\text { Capacitar médicos para a } \\
\text { interpretação de marcadores } \\
\text { sorológicos de hepatite B e } \\
\text { C e para o atendimento } \\
\text { humanizado à populac } \square \text { ão } \\
\text { de gays, HSH e travestis. }\end{array}$ & $\begin{array}{c}\text { Definir } \\
\text { servic } \square \text { os de } \\
\text { refere } \square \text { ncia } \\
\text { para o } \\
\text { diagnóstico, } \\
\text { assiste } \square \text { ncia e } \\
\text { tratamento das } \\
\text { DST/AIDS e } \\
\text { hepatites para, } \\
\text { pelo menos } 60 \% \\
\text { dos projetos da } \\
\text { OSC e de } \\
\text { governos. A } \\
\text { meta para } 2011 \text {, } \\
\text { é de } 100 \% \text {. }\end{array}$ & $\begin{array}{c}\text { Promoc } \square \text { ão } \\
\text { de fóruns de } \\
\text { discussão que } \\
\text { envolva o } \\
\text { movimento de } \\
\text { travestis, o } \\
\text { movimento de } \\
\text { aids e outras } \\
\text { instituic } \square \text { ões } \\
\text { e movimentos } \\
\text { com } \\
\text { iniciativas } \\
\text { relevantes no } \\
\text { campo da } \\
\text { saúde e do } \\
\text { enfrentamento } \\
\text { das } \\
\text { DST/HIV/aids } \\
\text {. } \\
\end{array}$ & $\begin{array}{c}\text { Produc } \square \text { ão e } \\
\text { produc } \square \text { ão de } \\
\text { materiais } \\
\text { informativos } \\
\text { para } \\
\text { profissionais } \\
\text { de saúde, } \\
\text { gerentes e } \\
\text { gestores que } \\
\text { inclua as } \\
\text { especificidade } \\
\text { s das travestis } \\
\text { (a questão do } \\
\text { uso de silicone } \\
\text { industrial e/ou } \\
\text { hormo } \square \text { nio, } \\
\text { reduc } \square \text { ão de } \\
\text { danos, dentre } \\
\text { outros). } \\
\end{array}$ & $\begin{array}{c}\text { Definir mecanismo } \\
\text { para coleta e } \\
\text { sistematização de } \\
\text { conhecimento e } \\
\text { informac } \square \text { ões } \\
\text { relacionadas às } \\
\text { travestis. Coleta de } \\
\text { dados sobre essa } \\
\text { populac } \square \text { ão } \\
\text { durante as Paradas } \\
\text { anuais } \\
\text { (estado/ONG). } \\
\text { Sistematizar e } \\
\text { divulgar os dados } \\
\text { existentes e } \\
\text { pesquisas em } \\
\text { andamento que } \\
\text { enfoquem travestis. }\end{array}$ \\
\hline $\begin{array}{c}\text { Realizar capacitac } \square \text { ão dos } \\
\text { profissionais do sistema } \\
\text { prisional para as ac } \square \text { ões de } \\
\text { prevenc } \square \text { ão às DST/aids e o } \\
\text { enfrentamento da } \\
\text { homofobia, em parceria com } \\
\text { as OSC e a Sec. de } \\
\text { Segurança Cidadã } ; \text { - se } \\
\text { referindo a travestis, gays e } \\
\text { HSH }\end{array}$ & $\begin{array}{c}\text { Mapear as } \\
\text { unidades de } \\
\text { refere } \square \text { ncia e } \\
\text { contrarrefere } \square \mathrm{n} \\
\text { cia para a } \\
\text { populac } \square \text { ão } \\
\text { (identificar } \\
\text { unidades, } \\
\text { incluindo } \\
\text { profissionais de } \\
\text { saúde que serão }\end{array}$ & $\begin{array}{c}\text { Integrar as } \\
\text { agendas de } \\
\text { prevenc } \square \text { ão } \\
\text { entre OG e } \\
\text { OSC (além da } \\
\text { disponibilizaç } \\
\text { ão de insumos } \\
\text { de } \\
\text { prevenc } \square \text { ão e } \\
\text { relatórios } \\
\text { quadrimestrais }\end{array}$ & $\begin{array}{c}\text { Produc } \square \text { ão e } \\
\text { produc } \square \text { ão de } \\
\text { materiais } \\
\text { informativos } \\
\text { para as } \\
\text { travestis que } \\
\text { inclua } \\
\text { aspectos como } \\
\text { cidadania, uso } \\
\text { de silicone } \\
\text { industrial e/ou }\end{array}$ & $\begin{array}{c}\text { Elaborar material } \\
\text { educativo } \\
\text { especifico voltado } \\
\text { à reduc } \square \text { ão de } \\
\text { danos às travestis } \\
\text { relacionados ao uso } \\
\text { de seringas e } \\
\text { agulhas na } \\
\text { ampliac } \square \text { ão de } \\
\text { silicone e } \\
\text { hormo } \square \text { nio, bem }\end{array}$ \\
\hline
\end{tabular}




\begin{tabular}{|c|c|c|c|c|}
\hline & $\begin{array}{c}\text { refere } \square \text { ncia } \\
\text { para o } \\
\text { atendimento de } \\
\text { gays, HSH e } \\
\text { travestis. }\end{array}$ & ). & $\begin{array}{l}\text { hormo } \square \text { nio, } \\
\text { reduc } \square \text { ão de } \\
\text { danos, dentre } \\
\text { outros, com a } \\
\text { participac } \square \text { ão } \\
\text { das travestis. }\end{array}$ & $\begin{array}{c}\text { como garantir o } \\
\text { fornecimento de } \\
\text { kits de reduc } \square \text { ão } \\
\text { de danos utilizados } \\
\text { nesses } \\
\text { procedimentos. }\end{array}$ \\
\hline $\begin{array}{l}\text { Realizar } 01 \text { conferencia } \\
\text { anual "A questão LGBT e o } \\
\text { Poder Judiciário" }\end{array}$ & $\begin{array}{c}\text { Conhecer os } \\
\text { servic } \square \text { os } \\
\text { existentes de } \\
\text { atenc } \square \text { ão à } \\
\text { saúde de } \\
\text { travestis no DF } \\
\text { e divulgá-los, de } \\
\text { maneira } \\
\text { oportuna, entre } \\
\text { as travestis, } \\
\text { através de OSC } \\
\text { e articulac } \square \text { ão } \\
\text { com o programa } \\
\text { de Saúde da } \\
\text { Família. }\end{array}$ & $\begin{array}{c}\text { Apoiar o } \\
\text { gestor estadual } \\
\text { e os gestores } \\
\text { municipais na } \\
\text { implantação } \\
\text { de projetos da } \\
\text { OSC e das } \\
\text { esferas } \\
\text { governamentai } \\
\text { s voltados para } \\
\text { prevenc } \square \text { ão } \\
\text { do HIV/aids e } \\
\text { das DST junto } \\
\text { aos } \\
\text { segmentos. }\end{array}$ & $\begin{array}{c}\text { Promover } \\
\text { junto aos } \\
\text { meios de } \\
\text { comunicac } \square \text { ã } \\
\text { o de massa a } \\
\text { veiculac } \square \text { ão } \\
\text { de mensagens } \\
\text { qualificadas } \\
\text { de promoc } \square \text { ão } \\
\text { dos direitos de } \\
\text { cidadania dos } \\
\text { gays, Travestis } \\
\text { e outros HSH. }\end{array}$ & $\begin{array}{l}\text { Definir quais os } \\
\text { OSC mecanismos } \\
\text { de avaliação do } \\
\text { desempenho e } \\
\text { qualidade de } \\
\text { servic } \square \text { o dos CTA } \\
\text { para atendimento e } \\
\text { acolhimento das } \\
\text { travestis. }\end{array}$ \\
\hline $\begin{array}{c}\text { Capacitac } \square \text { ão e } \\
\text { sensibilizac } \square \text { ão de } \\
\text { profissionais de saúde dos } \\
\text { servic } \square \text { os de diagnóstico e } \\
\text { aconselhamento em } \\
\text { DST/HIV/aids sobre } \\
\text { especificidades do } \\
\text { acolhimento aos gays, HSH } \\
\text { e travestis, diversidade, } \\
\text { orientac } \square \text { ão sexual e } \\
\text { identidade de ge } \square \text { nero, } \\
\text { visando a garantir a } \\
\text { participac } \square \text { ão dos mesmos } \\
\text { nas diversas ac } \square \text { ões. }\end{array}$ & & $\begin{array}{c}\text { Desenvolver } \\
\text { ac } \square \text { ões } \\
\text { articuladas } \\
\text { para } \\
\text { prevenc } \square \text { ão } \\
\text { das DST/aids } \\
\text { entre a } \\
\text { populac } \square \text { ão } \\
\text { LGBT. }\end{array}$ & $\begin{array}{c}\text { Desenvolver } \\
\text { pelo menos } \\
\text { uma } \\
\text { campanha } \\
\text { anual de } \\
\text { comunicac } \square \text { ã } \\
\text { o para } \\
\text { reduc } \square \text { ão da } \\
\text { vulnerabilidad } \\
\text { e, dar } \\
\text { visibilidade à } \\
\text { gravidade da } \\
\text { epidemia entre } \\
\text { gays, travestis } \\
\text { e outros HSH } \\
\text { e estimular o } \\
\text { diagnóstico e } \\
\text { tratamento das } \\
\text { DST, hepatites } \\
\text { e AIDS. }\end{array}$ & $\begin{array}{c}\text { Promover a } \\
\text { discussão e a } \\
\text { inclusão das } \\
\text { especificidades de } \\
\text { saúde das travestis } \\
\text { nas ac } \square \text { ões de } \\
\text { assiste } \square \text { ncia e } \\
\text { tratamento de } \\
\text { travestis que vivem } \\
\text { com HIV/aids. }\end{array}$ \\
\hline $\begin{array}{c}\text { Capacitar } 50 \text { gestorese } 150 \\
\text { profissionais da saúde, } \\
\text { assiste } \square \text { ncia social, } \\
\text { educac } \square \text { ão para } \\
\text { compreensão dos temas } \\
\text { pertinentes ao } \\
\text { enfrentamento da epidemia } \\
\text { da aids em sua } \\
\text { complexidade (na } \\
\text { prevenc } \square \text { ão, na } \\
\text { promoc } \square \text { ão, no controle } \\
\text { social) e os papéis exercidos } \\
\text { pelos gestores e } \\
\text { profissionais na tarefa do } \\
\text { enfrentamento da AIDS } \\
\text { garantindo prioridade para } \\
\text { gays, HSH e travestis. }\end{array}$ & & $\begin{array}{c}\text { Implantar } \\
\text { mecanismos } \\
\text { para } \\
\text { intercambio de } \\
\text { informac } \square \text { ão, } \\
\text { experie } \square \text { ncias } \\
\text { e cooperação } \\
\text { entre o } \\
\text { Distrito } \\
\text { Federal e as } \\
\text { OSC, criando } \\
\text { um "e-group" } \\
\text { para troca de } \\
\text { informac } \square \text { ões, } \\
\text { acompanhame } \\
\text { nto e } \\
\text { atualização } \\
\text { dos diversos } \\
\text { setores }\end{array}$ & $\begin{array}{l}\text { Desenvolver } \\
\text { material } \\
\text { publicitário } \\
\text { educativo } \\
\text { especifico que } \\
\text { contemple as } \\
\text { multiplas } \\
\text { identidades } \\
\text { gays, HSH e } \\
\text { travestis. }\end{array}$ & $\begin{array}{l}\text { Ampliar o numero } \\
\text { de CTA no Estado } \\
\text { do Pará para o } \\
\text { atendimento às } \\
\text { travestis. }\end{array}$ \\
\hline
\end{tabular}




\begin{tabular}{|c|c|c|c|}
\hline & envolvidos. & & \\
\hline $\begin{array}{c}\text { Reciclar/capacitar agentes } \\
\text { comunitários de saúde sobre } \\
\text { DST/HIV/aids, voltado para } \\
\text { as especificidades de gays, } \\
\text { HSH e travestis. }\end{array}$ & $\begin{array}{l}\text { Dimensionam } \\
\text { ento de } \\
\text { necessidades e } \\
\text { cadastramento } \\
\text { de todas as } \\
\text { instituic } \square \text { ões } \\
\text { que } \\
\text { desenvolvem } \\
\text { trabalhos com } \\
\text { gays, HSH e } \\
\text { travestis (MT) }\end{array}$ & $\begin{array}{c}\text { Produzir e } \\
\text { veicular três } \\
\text { peças } \\
\text { publicitarias - } \\
\text { esta ação se } \\
\text { relaciona com } \\
\text { a meta } \\
\text { mensagens } \\
\text { qualificadas } \\
\text { para a resposta } \\
\text { à epidemia de } \\
\text { DST/aids e } \\
\text { promoc } \square \text { ão } \\
\text { dos direitos de } \\
\text { cidadania dos } \\
\text { gays, travestis } \\
\text { e outros HSH. }\end{array}$ & $\begin{array}{l}\text { Considerar as } \\
\text { especificidades de } \\
\text { saúde das travestis } \\
\text { que vivem com } \\
\text { HIV/aids nas } \\
\text { ac } \square \text { ões de } \\
\text { assiste } \square \text { ncia e } \\
\text { tratamento. }\end{array}$ \\
\hline $\begin{array}{c}\text { Capacitac } \square \text { ão para } \\
\text { profissionais de saúde, ONG } \\
\text { e profissionais afins com } \\
\text { vistas a atender as } \\
\text { necessidades dos gays, HSH } \\
\text { e travestis (MG) Fala-se de } \\
\text { necesidades e } \\
\text { especificidades mas não é } \\
\text { possivel verificar se há um } \\
\text { conhecimento sobre o que } \\
\text { seja isso. }\end{array}$ & $\begin{array}{c}\text { Realizar duas } \\
\text { reuniões } \\
\text { anuais } \\
\text { ampliadas } \\
\text { com foco no } \\
\text { diálogo e } \\
\text { articulac } \square \text { ão } \\
\text { entre } \\
\text { representantes } \\
\text { do movimento } \\
\text { de travestis, } \\
\text { gestores, } \\
\text { gerentes e } \\
\text { profissionais } \\
\text { do servic } \square \text { o } \\
\text { de saúde, para } \\
\text { discutir } \\
\text { assuntos como } \\
\text { inclusão das } \\
\text { especificidade } \\
\text { s das travestis, } \\
\text { acesso ao } \\
\text { proctologista, } \\
\text { urologista, } \\
\text { hormonoterapi } \\
\text { a e } \\
\text { informac } \square \text { ões } \\
\text { sobre os riscos } \\
\text { de uso de } \\
\text { silicone } \\
\text { industrial e o } \\
\text { acesso a } \\
\text { próteses de } \\
\text { silicone } \\
\end{array}$ & $\begin{array}{l}\text { Garantir } \\
\text { inclusão de } \\
\text { campanha } \\
\text { estadual às } \\
\text { travestis }\end{array}$ & \\
\hline $\begin{array}{l}\text { Realizar encontro entre } \\
\text { gestores municipais e dos } \\
\text { Centros Regionais de Saúde } \\
\text { para sensibilizac } \square \text { ão } \\
\text { referente às temáticas das } \\
\text { populações de gays, outros } \\
\text { HSH e travestis. }\end{array}$ & & $\begin{array}{l}\text { Elaborar e } \\
\text { confeccionar } \\
\text { material } \\
\text { informativo/ed } \\
\text { ucativo em } \\
\text { realizac } \square \text { ão à } \\
\text { saúde da } \\
\text { populac } \square \text { ão }\end{array}$ & \\
\hline
\end{tabular}




\begin{tabular}{|c|c|}
\hline & $\begin{array}{l}\text { de gays, HSH } \\
\text { e travestis. }\end{array}$ \\
\hline $\begin{array}{l}\text { Realizar capacitac } \square \text { ão em } \\
\text { Direitos Humanos para } \\
\text { profissionais dessas áreas, } \\
\text { com foco nos direitos } \\
\text { sexuais e reprodutivos, na } \\
\text { homofobia e na transfobia. }\end{array}$ & $\begin{array}{c}\text { Incluir, nos } \\
\text { servic } \square \text { os de } \\
\text { assiste } \square \text { ncia a } \\
\text { travestis, } \\
\text { campanhas de } \\
\text { sensibilizac } \square \text { ã } \\
\text { o e } \\
\text { prevenc } \square \text { ão } \\
\text { AO } \\
\text { HIV/AIDS }\end{array}$ \\
\hline $\begin{array}{c}\text { Investir na } \\
\text { capacitac } \square \text { ão/formac } \square \text { ão e } \\
\text { sensibilizac } \square \text { ão de OSC } \\
\text { para a atualizac } \square \text { ão sobre a } \\
\text { epidemia e formas de } \\
\text { prevenc } \square \text { ão para OSC dos } \\
\text { três segmentos. }\end{array}$ & $\begin{array}{c}\text { Promover, } \\
\text { para cada } \\
\text { segmento, } \\
\text { campanhas } \\
\text { que ofereçam } \\
\text { informac } \square \text { ões } \\
\text { sobre } \\
\text { prevenc } \square \text { ão e } \\
\text { teste. }\end{array}$ \\
\hline $\begin{array}{l}\text { Realizar três capacitac } \square \text { ões } \\
\text { com profissionais de saúde } \\
\text { sobre identificac } \square \text { ão das } \\
\text { necessidades profissionais } \\
\text { (ex.: ética, humanizac } \square \text { ão, } \\
\text { etc.) das vulnerabilidades na } \\
\text { populac } \square \text { ão de gays, HSH e } \\
\text { travestis em âmbito estadual } \\
\text { e municipal. }\end{array}$ & $\begin{array}{c}\text { Realizar edital } \\
\text { para realizar } \\
\text { campanha de } \\
\text { prevenc } \square \text { ão e } \\
\text { diminuição do } \\
\text { estigma entre } \\
\text { a populac } \square \text { ão } \\
\text { de gays, HSH } \\
\text { e travestis } \\
\text { vinculadas no } \\
\text { meio de } \\
\text { comunicac } \square \text { ã } \\
\text { o de massa, } \\
\text { garantindo que } \\
\text { o foco e as } \\
\text { imagens sejam } \\
\text { impactantes } \\
\text { sobre esse } \\
\text { público. }\end{array}$ \\
\hline $\begin{array}{c}\text { Realizar } \\
\text { capacitac } \square \text { ão/qualificac } \square \text { ão } \\
\text { dos profissionais de saúde } \\
\text { da rede básica para o } \\
\text { acolhimento das populações } \\
\text { gays, HSH e travestis. }\end{array}$ & $\begin{array}{c}\text { Fazer cartilha } \\
\text { com } \\
\text { realizac } \square \text { ão } \\
\text { das Unidades } \\
\text { de Saúde e dos } \\
\text { servic } \square \text { os } \\
\text { oferecidos } \\
\text { para os três } \\
\text { segmentos } \\
\text { (gays, HSH e } \\
\text { travestis); }\end{array}$ \\
\hline $\begin{array}{c}\text { Sensibilizar e } \\
\text { instrumentalizar os } \\
\text { profissionais dos NAS (AT. } \\
\text { B.) para incluir as temáticas } \\
\text { relacionadas à saúde de } \\
\text { HSH, Gays e Travestis no } \\
\text { apoio técnico as unidades de } \\
\text { Saúde da Família, } \\
\text { objetivando a qualificac } \square \text { ão }\end{array}$ & $\begin{array}{c}\text { Promover } \\
\text { divulgac } \square \text { ão } \\
\text { nos meios de } \\
\text { comunicac } \square \text { ã } \\
\text { o em massa } \\
\text { para reduc } \square \text { ão } \\
\text { da } \\
\text { vulnerabilidad } \\
\text { e às DST/aids }\end{array}$ \\
\hline
\end{tabular}




\begin{tabular}{|c|c|c|}
\hline $\begin{array}{l}\text { do cuidado a essas } \\
\text { populações. }\end{array}$ & $\begin{array}{c}\text { e } \\
\text { enfrentamento } \\
\text { da homofobia } \\
\text { e transfobia. }\end{array}$ & \\
\hline $\begin{array}{c}\text { Discutir e implantar } \\
\text { capacitac } \square \text { ão e } \\
\text { sensibilizac } \square \text { ão continua de } \\
\text { profissionais dos servic } \square \text { os } \\
\text { de saúde no atendimento as } \\
\text { DST/HIV/aids em temas } \\
\text { relacionados ao universo e } \\
\text { demandas dos gays, outros } \\
\text { HSH e travestis, frente a } \\
\text { esses agravos à saúde e ao } \\
\text { combate ao estigma e } \\
\text { discriminação devido à } \\
\text { orientac } \square \text { ão sexual e } \\
\text { identidade de ge } \square \text { nero. }\end{array}$ & $\begin{array}{l}\text { Estabelecer } \\
\text { parcerias } \\
\text { interinstitucio } \\
\text { nais com MPE } \\
\text { para reverter } \\
\text { as penas } \\
\text { alternativas } \\
\text { em produc } \square \text { ão } \\
\text { de materiais } \\
\text { informativos e } \\
\text { educativo } \\
\text { visando } \\
\text { trabalhar } \\
\text { populações } \\
\text { vulneráveis } \\
\text { (restritas de } \\
\text { liberdades, } \\
\text { LGBT, HSH e } \\
\text { indígenas). }\end{array}$ & \\
\hline $\begin{array}{l}\text { Capacitar profissionais de } \\
\text { saúde para a implantação } \\
\text { (diagnóstico, tratamento e } \\
\text { acompanhamento) da } \\
\text { profilaxia pós-exposic } \square \text { ão, } \\
\text { para a revisão de rede de } \\
\text { refere } \square \text { ncia e } \\
\text { contrarrefere } \square \text { ncia para } \\
\text { profílaxia pós-exposic } \square \text { ão e } \\
\text { para a assiste } \square \text { ncia das } \\
\text { pessoas que tiveram } \\
\text { exposic } \square \text { ão sexual. }\end{array}$ & $\begin{array}{c}\text { Elaborar e } \\
\text { confeccionar } \\
\text { materiais } \\
\text { educativos } \\
\text { sobre a } \\
\text { temática de } \\
\text { PVHA e } \\
\text { qualidade de } \\
\text { vida. }\end{array}$ & \\
\hline $\begin{array}{l}\text { Realizar encontros regionais } \\
\text { com todos os profissionais } \\
\text { que participam da rede de } \\
\text { atenc } \square \text { ão à violência sexual } \\
\text { para discussão do tema. } \\
\text { Relacionado ao objetivo Ter } \\
\text { incorporado, até dezembro } \\
\text { de } 2012 \text {, na rede de } \\
\text { atenc } \square \text { ão às vitimas de } \\
\text { violência sexual, o } \\
\text { atendimento a gays, HSH e } \\
\text { travestis, articulando os } \\
\text { diversos níveis de } \\
\text { complexidade de atenc } \square \text { ão, } \\
\text { garantindo os } \\
\text { procedimentos de } \\
\text { prevenc } \square \text { ão, tratamento e } \\
\text { profilaxia para as DST/aids. }\end{array}$ & $\begin{array}{c}\text { Mobilizar os } \\
\text { meios de } \\
\text { comunicac } \square \text { ã } \\
\text { o de massa e } \\
\text { as mídias GLS } \\
\text { e travestis para } \\
\text { a veiculac } \square \text { ão } \\
\text { de mensagens } \\
\text { qualificadas } \\
\text { de } \\
\text { prevenc } \square \text { ão } \\
\text { das DST/aids } \\
\text { e de } \\
\text { promoc } \square \text { ão } \\
\text { dos direitos de } \\
\text { cidadania dos } \\
\text { gays, outros } \\
\text { HSH e } \\
\text { travestis }\end{array}$ & \\
\hline $\begin{array}{l}\text { Inserir, nas capacitac } \square \text { ões } \\
\text { previstas pela Coordenação } \\
\text { Estadual de DST/HIV/Aids, } \\
\text { a inclusão de questões } \\
\text { associadas aos gays, HSH e } \\
\text { travestis. (MS) Inespecífico }\end{array}$ & $\begin{array}{l}\text { Realizar uma } \\
\text { campanha de } \\
\text { comunicac } \square \tilde{a} \\
\text { o para } \\
\text { reduc } \square \text { ão da } \\
\text { vulnerabilidad }\end{array}$ & \\
\hline
\end{tabular}




\begin{tabular}{|c|c|}
\hline & $\begin{array}{c}\mathrm{e}, \mathrm{dar} \\
\text { visibilidade à } \\
\text { gravidade da } \\
\text { epidemia entre } \\
\text { gays, outros } \\
\text { HSH e } \\
\text { travestis e } \\
\text { estimular o } \\
\text { diagnóstico e } \\
\text { tratamento das } \\
\text { DST/HIV/aids }\end{array}$ \\
\hline $\begin{array}{c}\text { Ter equipes capacitadas } \\
\text { para atender as demandas } \\
\text { para o enfrentamento das } \\
\text { DST/AIDS entre gays, } \\
\text { outros HSH e travestis nos } \\
\text { Programas Estadual e nos } \\
223 \text { municípios. }\end{array}$ & $\begin{array}{c}\text { Trabalhar } \\
\text { diretamente } \\
\text { com o setor de } \\
\text { comunicac } \square \text { ã } \\
\text { o da SES para } \\
\text { definição dos } \\
\text { parâmetros } \\
\text { técnico que } \\
\text { nortearão as } \\
\text { campanhas de } \\
\text { prevenc } \square \text { ão } \\
\text { das DST/aids } \\
\text { e de } \\
\text { promoc } \square \text { ão } \\
\text { dos direitos de } \\
\text { cidadania dos } \\
\text { gays, outros } \\
\text { HSH e } \\
\text { travestis, } \\
\text { seguidos da } \\
\text { respectiva } \\
\text { operacionaliza } \\
\text { ção. }\end{array}$ \\
\hline $\begin{array}{c}\text { Realizar capacitac } \square \text { ão } \\
\text { permanente envolvendo as } \\
\text { Equipes do PSP - Programa } \\
\text { de saúde nos Presídios, } \\
\text { visando a humanizac } \square \text { ão } \\
\text { nos atendimentos } \\
\text { ambulatoriais no Sistema } \\
\text { Penitenciário relacionado ao } \\
\text { objetivo Garantir acesso } \\
\text { universal a prevenc } \square \text { ão e } \\
\text { assiste } \square \text { ncia das } \\
\text { DST/HIV/AIDS para gays } \\
\text { Travestis e outros HSH no } \\
\text { Sistema Penitenciário do } \\
\text { estado. }\end{array}$ & $\begin{array}{c}\text { Sensibilizar } \\
\text { formadores de } \\
\text { opinião } \\
\text { (setores de } \\
\text { comunicac } \square \text { ã } \\
\text { o e/ou e } \\
\text { pessoas chave) } \\
\text { sobre } \\
\text { formulac } \square \text { ão } \\
\text { de mensagens } \\
\text { relacionadas } \\
\text { às travestis, na } \\
\text { perspectiva de } \\
\text { ampliar o } \\
\text { conhecimento } \\
\text { sobre o } \\
\text { segmento e } \\
\text { diminuir } \\
\text { equívocos } \\
\text { e/ou } \\
\text { mensagens } \\
\text { negativas. }\end{array}$ \\
\hline $\begin{array}{l}\text { Realizac } \square \text { ão de quatro } \\
\text { capacitac } \square \text { ões de } \\
\text { profissionais sobre }\end{array}$ & $\begin{array}{l}\text { Produzir e } \\
\text { divulgar } \\
\text { material }\end{array}$ \\
\hline
\end{tabular}




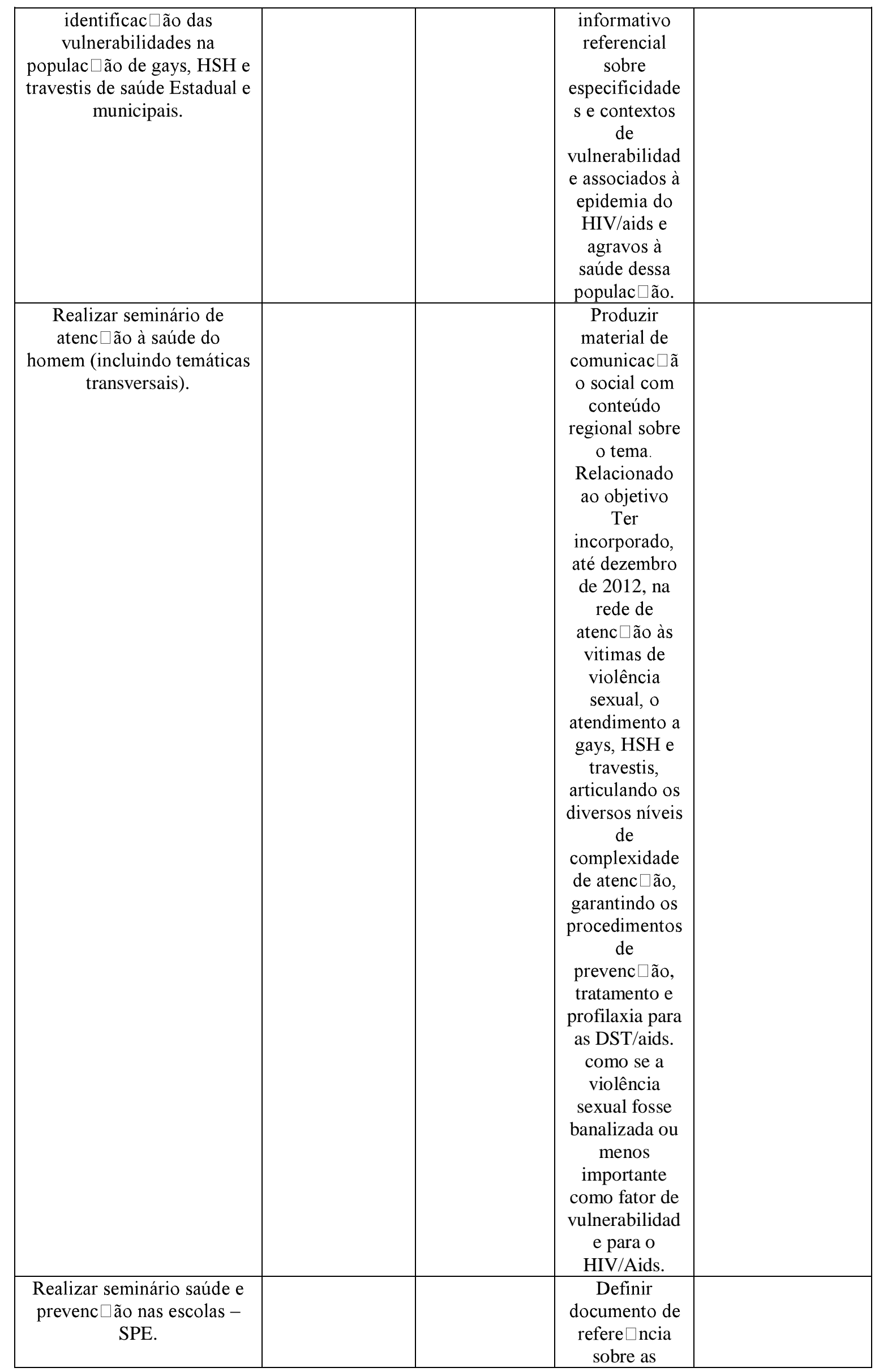




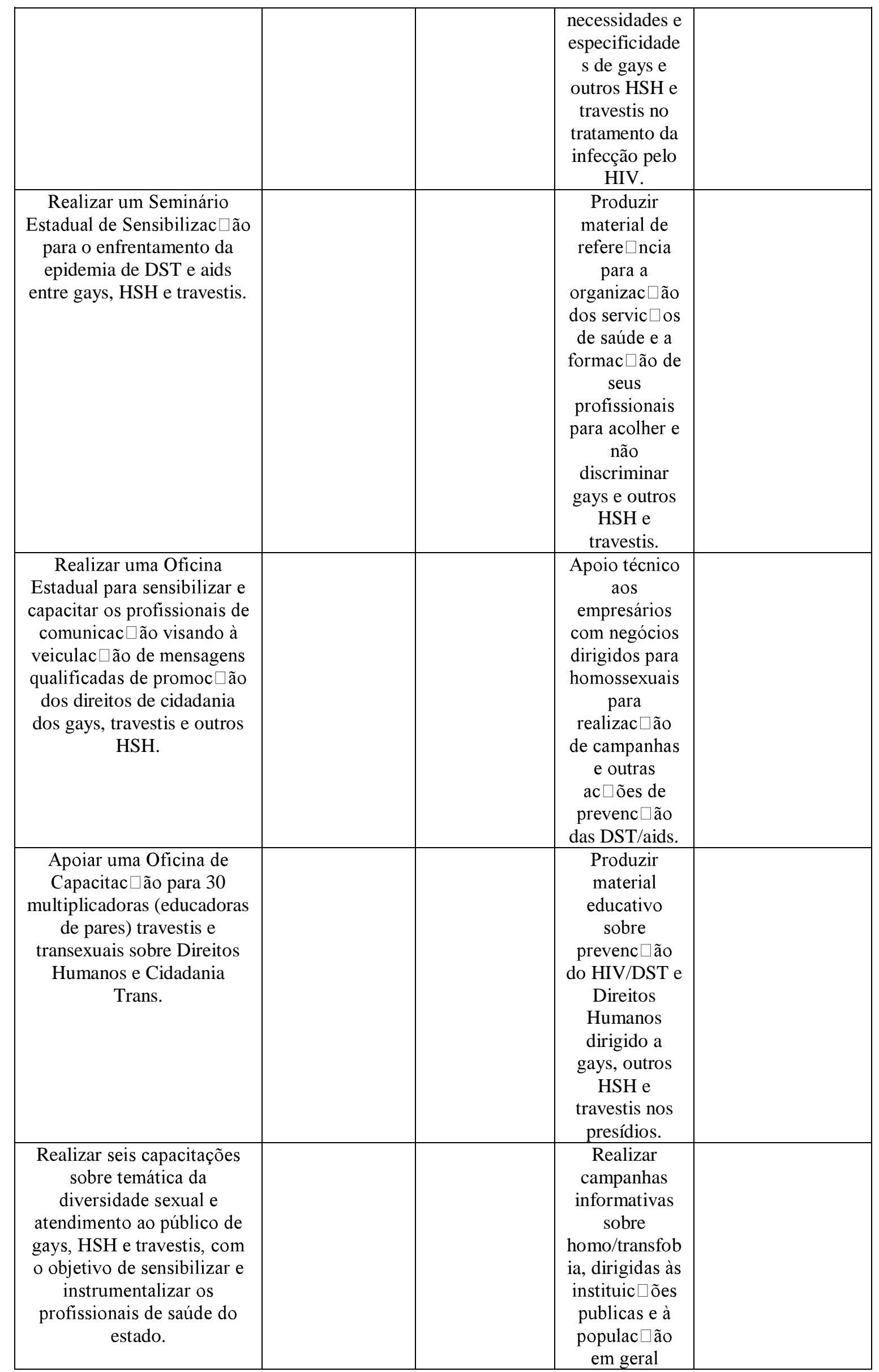




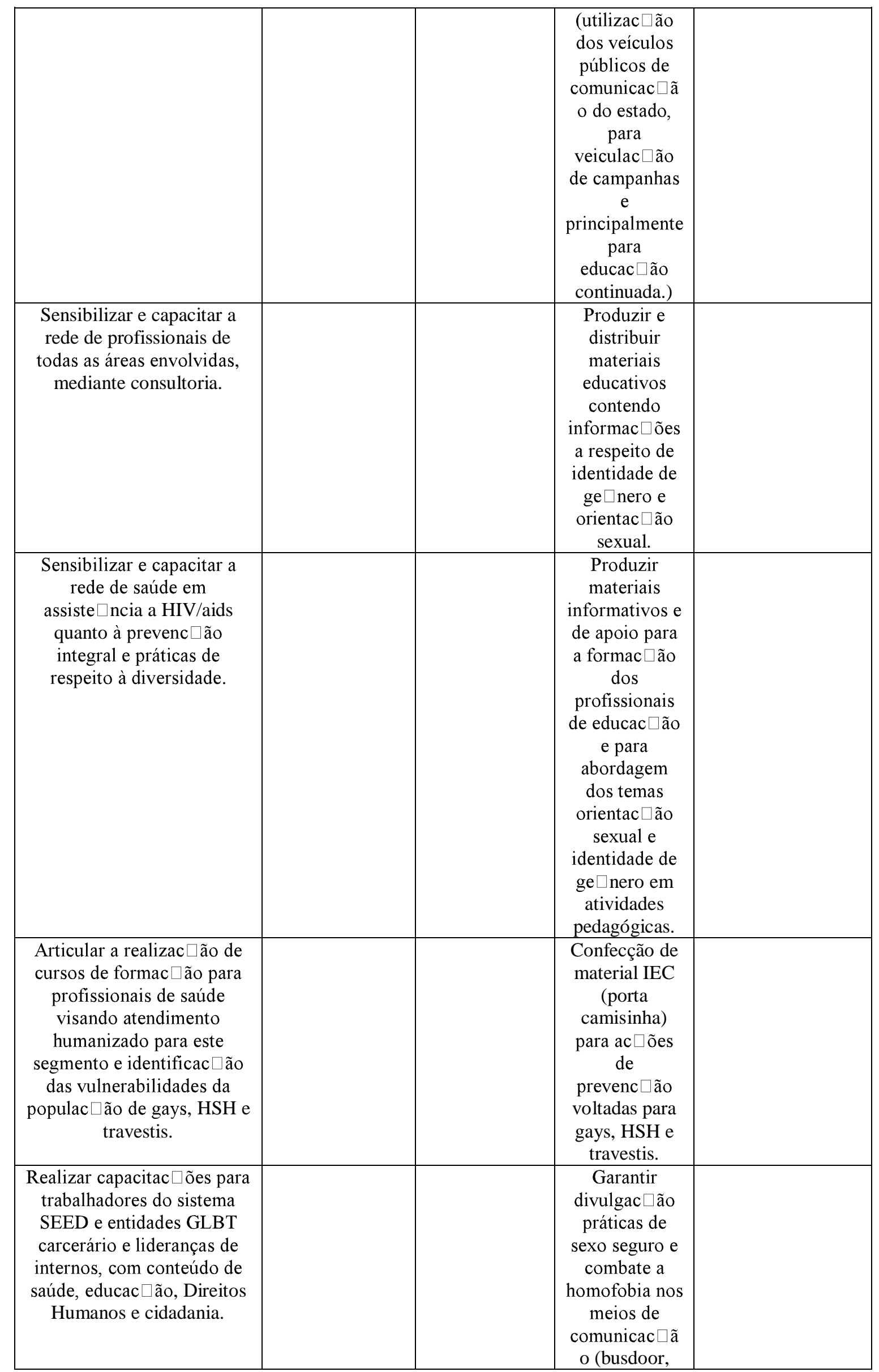




\begin{tabular}{|c|c|}
\hline & $\begin{array}{c}\text { outdoors, } \\
\text { spots para } \\
\text { radio, TV). }\end{array}$ \\
\hline $\begin{array}{c}\text { Apoiar a realizac } \square \text { ão de } \\
\text { capacitac } \square \text { óes em Direitos } \\
\text { SEED, SEJUC, SSP e } \\
\text { Humanos, direitos sexuais e } \\
\text { o enfrentamento da } \\
\text { Movimento GLBT } \\
\text { homofobia e transfobia, } \\
\text { sendo uma em cada } \\
\text { regional, para profissionais } \\
\text { dessas áreas. }\end{array}$ & $\begin{array}{c}\text { Criar } \\
\text { estratégia em } \\
\text { multimídia, } \\
\text { cursos à } \\
\text { distancia } \\
\text { (internet, radio } \\
\text { comunitária, } \\
\text { comunidade } \\
\text { virtual, blogs, } \\
\text { Orkut) para } \\
\text { estabelecer } \\
\text { redes de } \\
\text { disseminação } \\
\text { de } \\
\text { informac } \square \text { ões } \\
\text { e orientações e } \\
\text { divulgac } \square \text { ão } \\
\text { de eventos. }\end{array}$ \\
\hline $\begin{array}{c}\text { Realizar eventos } \\
\text { (seminários, palestras e } \\
\text { oficinas), visando } \\
\text { sensibilizac } \square \text { ão junto a } \\
\text { profissionais da área de } \\
\text { saúde que atendem no } \\
\text { sistema UBS, ambulatórios, } \\
\text { hospitais e outros sobre } \\
\text { orientac } \square \text { ão sexual e } \\
\text { identidade de ge } \square \text { nero. }\end{array}$ & $\begin{array}{c}\text { Articular e } \\
\text { garantir um } \\
\text { instrumento } \\
\text { politico } \\
\text { (Termo de } \\
\text { Compromisso) } \\
\text { com gestores } \\
\text { municipais } \\
\text { para a } \\
\text { produc } \square \text { ão de } \\
\text { materiais } \\
\text { didáticos e } \\
\text { outros, } \\
\text { contendo } \\
\text { informac } \square \text { ões } \\
\text { sobre leis de } \\
\text { enfrentamento } \\
\text { à homofobia e } \\
\text { demais } \\
\text { questões } \\
\text { relacionadas à } \\
\text { saúde da } \\
\text { populac } \square \text { ão } \\
\text { de gays, HSH, } \\
\text { travestis e } \\
\text { PVHA; }\end{array}$ \\
\hline $\begin{array}{l}\text { Capacitar os profissionais } \\
\text { da rede de alta, baixa e } \\
\text { media complexidade para } \\
\text { atendimento à populac } \square \text { ão } \\
\text { LGBT e PVHA (trabalho } \\
\text { intersetorial - ETSUS, } \\
\text { Secretarias, UFT). }\end{array}$ & $\begin{array}{c}\text { Articular e } \\
\text { garantir um } \\
\text { instrumento } \\
\text { politico } \\
\text { (Termo de } \\
\text { Compromisso) } \\
\text {, junto a } \\
\text { gestores } \\
\text { municipais, } \\
\text { para a } \\
\text { produc } \square \text { ão de } \\
\text { materiais de } \\
\text { IEC e outros, }\end{array}$ \\
\hline
\end{tabular}




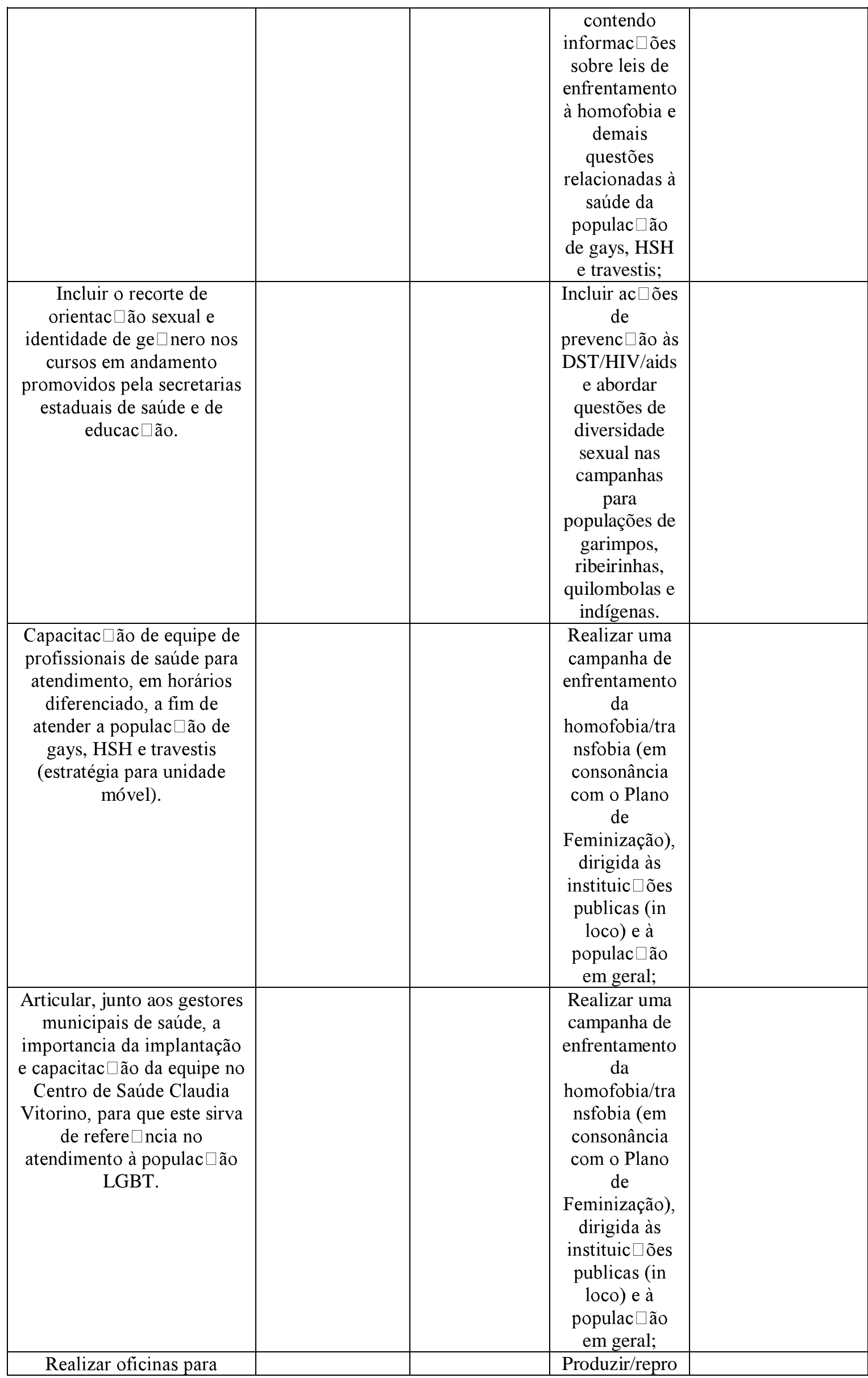




\begin{tabular}{|c|c|}
\hline $\begin{array}{l}\text { profissionais da "Saúde da } \\
\text { Família" enfocando a } \\
\text { Reduc } \square \text { ão de Danos para } \\
\text { ACS em todo o Estado do } \\
\text { Acre. }\end{array}$ & $\begin{array}{l}\text { duzir material } \\
\text { relacionado ao } \\
\text { enfrentamento } \\
\text { da } \\
\text { homofobia/tra } \\
\text { nsfobia; }\end{array}$ \\
\hline $\begin{array}{c}\text { Realizar capacitac } \square \text { ão } \\
\text { humanizada de profissionais } \\
\text { de saúde, CRAS e Policia } \\
\text { Militar (Policia da Família) } \\
\text { para qualificar o } \\
\text { atendimento, melhorar a } \\
\text { adesão, dar visibilidade às } \\
\text { especificidades e ampliar a } \\
\text { rede de formac } \square \text { ão. }\end{array}$ & $\begin{array}{c}\text { Apoiar as } \\
\text { campanhas } \\
\text { nacionais de } \\
\text { informac } \square \text { ão } \\
\text { e outras } \\
\text { estratégia de } \\
\text { comunicac } \square \text { ã } \\
\text { o voltadas } \\
\text { para o } \\
\text { combate ao } \\
\text { preconceito e } \\
\text { transfobia e } \\
\text { reforço da } \\
\text { visibilidade } \\
\text { positiva das } \\
\text { travestis. }\end{array}$ \\
\hline $\begin{array}{l}\text { Capacitar profissionais de } \\
\text { saúde de nivel superior, } \\
\text { indicados pelo Fórum de } \\
\text { ONG/Aids para a realização } \\
\text { de testes rápidos anti-HIV } \\
\text { em locais estratégicos, para } \\
\text { alcance de travestis, no } \\
\text { período noturno, mediante } \\
\text { autorização do } \\
\text { Departamento de DST, Aids } \\
\text { e HV. }\end{array}$ & $\begin{array}{l}\text { Produzir e } \\
\text { veicular } \\
\text { campanhas } \\
\text { dirigidas à } \\
\text { populac } \square \text { ão } \\
\text { em geral para } \\
\text { o combate à } \\
\text { homofobia e } \\
\text { transfobia }\end{array}$ \\
\hline $\begin{array}{c}\text { Efetivar parcerias com as } \\
\text { áreas técnicas - Atenc } \square \text { ão } \\
\text { Básica, Saúde Mental, } \\
\text { Saúde Bucal, Saúde do } \\
\text { Idoso. Incluir nas } \\
\text { capacitac } \square \text { ões o tema } \\
\text { prevenc } \square \text { ão às DST, HIV e } \\
\text { aids. }\end{array}$ & $\begin{array}{c}\text { Realizac } \square \text { ão, } \\
\text { em parceria } \\
\text { com o Plano } \\
\text { Nacional } \\
\text { LGBT, de } \\
\text { campanhas } \\
\text { nos meios de } \\
\text { comunicac } \square \text { ã } \\
\text { o de massa, } \\
\text { dirigidas aos } \\
\text { gays, HSH e } \\
\text { travestis e à } \\
\text { populac } \square \text { ão } \\
\text { em geral }\end{array}$ \\
\hline $\begin{array}{l}\text { Fortalecimento das ac } \square \text { ões } \\
\text { intersetoriais, através da } \\
\text { realizac } \square \text { ão do Seminário } \\
\text { "Populações Vulneráveis e } \\
\text { sua realizac } \square \text { ão com os } \\
\text { Servic } \square \text { os de Saúde". }\end{array}$ & $\begin{array}{c}\text { Criac } \square \text { ão de } \\
\text { material } \\
\text { educativo para } \\
\text { divulgac } \square \text { ão } \\
\text { dos Direitos } \\
\text { Humanos e } \\
\text { sexuais dessa } \\
\text { populac } \square \text { ão } \\
\end{array}$ \\
\hline $\begin{array}{c}\text { Incluir a temática } \\
\text { diversidade sexual nas } \\
\text { capacitac } \square \text { ões promovidas } \\
\text { pelas seguintes áreas } \\
\text { técnicas: Saúde do }\end{array}$ & $\begin{array}{l}\text { Realizar 01 } \\
\text { (uma) } \\
\text { Campanha de } \\
\text { homofobia e } \\
\text { transfobia no }\end{array}$ \\
\hline
\end{tabular}




\begin{tabular}{|c|c|c|}
\hline $\begin{array}{l}\text { Adolescente e do Jovem, } \\
\text { Saúde no Sistema Prisional, } \\
\text { saúde do homem. }\end{array}$ & $\begin{array}{l}\text { Estado do Pará } \\
\text { dirigida à } \\
\text { populac } \square \text { ão } \\
\text { em geral e às } \\
\text { instituic } \square \text { ões } \\
\text { publicas }\end{array}$ & \\
\hline $\begin{array}{l}\text { Realizar treinamento com } \\
70 \text { Coordenac } \square \text { ões } \\
\text { municipais da atenc } \square \text { ão } \\
\text { básica acerca da } \\
\text { integralidade da atenc } \square \text { ão à } \\
\text { saúde da pop. de gay, HSH } \\
\text { e travestis, com foco na } \\
\text { intersetorialidade. }\end{array}$ & $\begin{array}{c}\text { Produzir/repro } \\
\text { duzir material } \\
\text { voltado ao } \\
\text { combate à } \\
\text { homofobia/tra } \\
\text { nsfobia. }\end{array}$ & \\
\hline $\begin{array}{l}\text { Realizar articulac } \square \text { ão com } \\
\text { as áreas técnicas para } \\
\text { inclusão das informac } \square \text { ões } \\
\text { sobre a populac } \square \text { ão de } \\
\text { gays, HSH e travestis em } \\
\text { todas as capacitac } \square \text { ões de } \\
\text { suas respectivas áreas. }\end{array}$ & $\begin{array}{c}\text { Articular com } \\
\text { o setor } \\
\text { empresarial o } \\
\text { desenvolvime } \\
\text { nto de } \\
\text { campanha de } \\
\text { combate à } \\
\text { homofobia/tra } \\
\text { nsfobia nas } \\
\text { empresas } \\
\text { privadas. }\end{array}$ & \\
\hline $\begin{array}{l}\text { Realizar encontro entre } \\
\text { gestores municipais e dos } \\
\text { Centros Regionais de Saúde } \\
\text { para sensibilizac } \square \text { ão } \\
\text { referente às temáticas das } \\
\text { populações de gays, outros } \\
\text { HSH e travestis. }\end{array}$ & & \\
\hline $\begin{array}{c}\text { Articular com gestores } \\
\text { municipais a realizac } \square \text { ão de } \\
\text { cursos de formac } \square \text { ão de } \\
\text { profissionais dos setores da } \\
\text { saúde, da educac } \square \text { ão e da } \\
\text { assiste } \square \text { ncia social para o } \\
\text { enfrentamento da } \\
\text { homofobia e atendimento } \\
\text { humanizado a gays, HSH, } \\
\text { travestis e PVHA. }\end{array}$ & & \\
\hline $\begin{array}{c}\text { Articular com gestores } \\
\text { municipais a realizac } \square \text { ão de } \\
\text { cursos de formac } \square \text { ão de } \\
\text { profissionais de saúde para } \\
\text { o enfrentamento da } \\
\text { homofobia e atendimento } \\
\text { humanizado a gays, outros } \\
\text { HSH e travestis. }\end{array}$ & & \\
\hline $\begin{array}{l}\text { Capacitar profissionais de } \\
\text { saúde de nivel superior, } \\
\text { indicados pelo Fórum de } \\
\text { ONG/Aids para realizac } \square \text { ão } \\
\text { de testes rápidos anti-HIV } \\
\text { em locais estratégicos, para } \\
\text { alcance de travestis, no } \\
\text { período noturno, mediante } \\
\text { autorização do Depto. de } \\
\text { DST, Aids e Hepatites }\end{array}$ & & \\
\hline
\end{tabular}




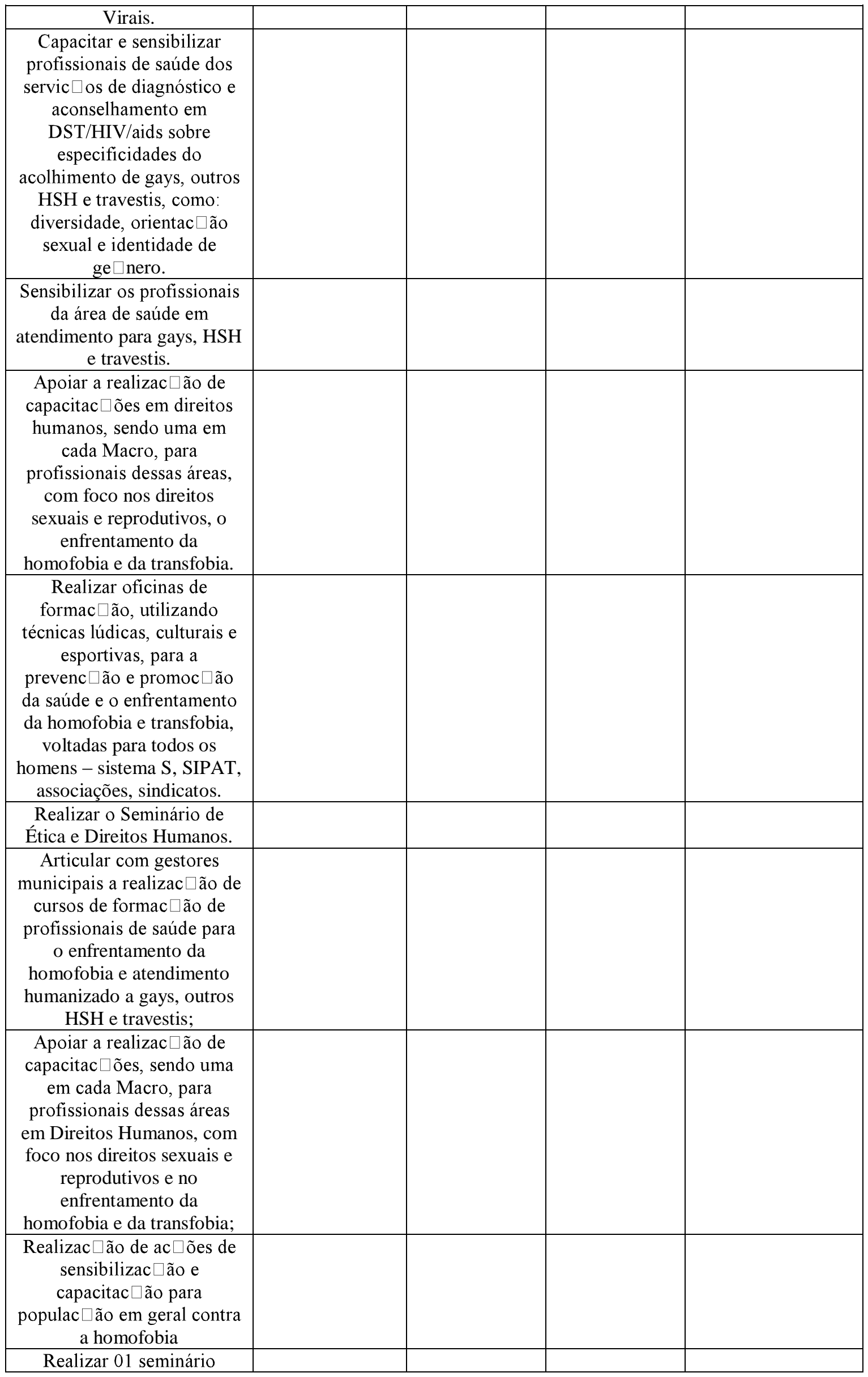




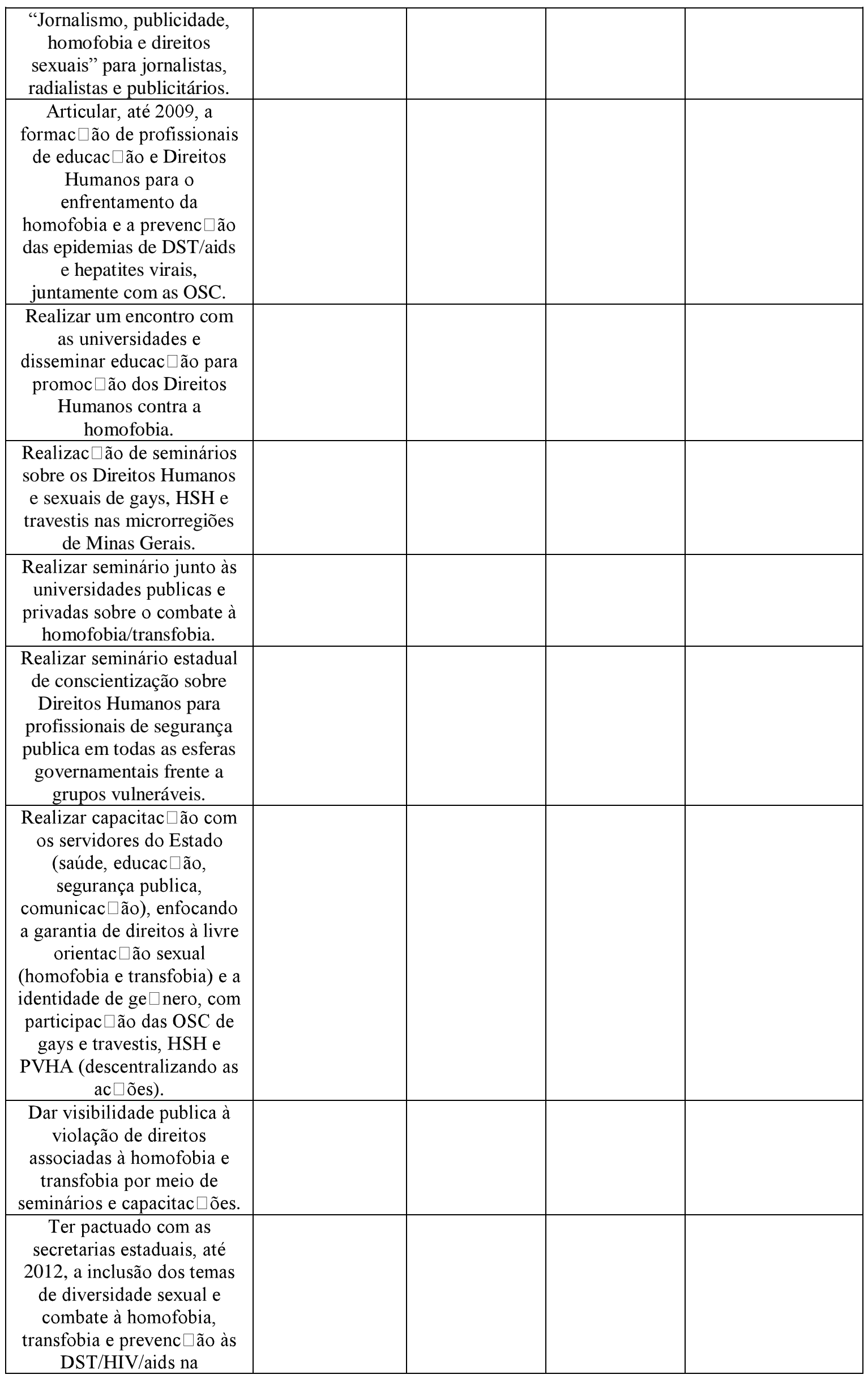


formac $\square$ ão inicial e continuada de servidores públicos, prioritariamente das áreas de saúde, educac $\square$ ão, segurança publica, justiça e cultura. 